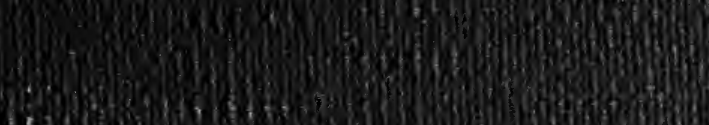

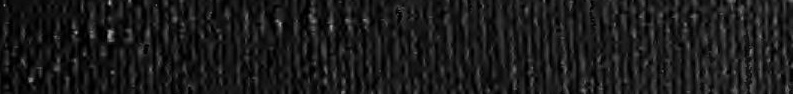
Sir. W. (4) 6.4. (3) fonsty

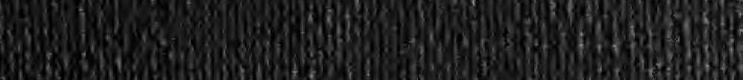
10.

3.

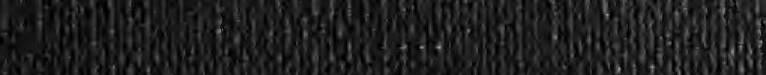
How

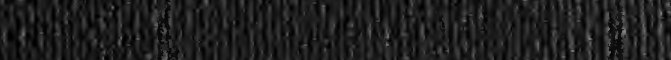
30 . D. Non 


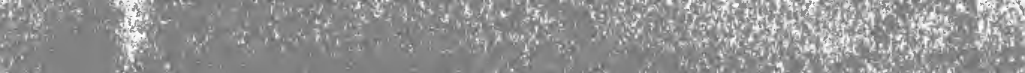

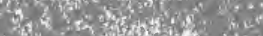

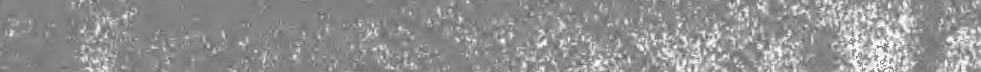

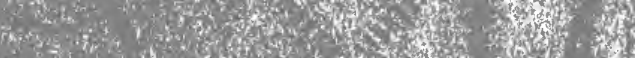

So

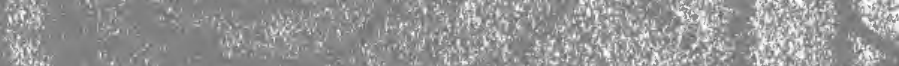

(10.

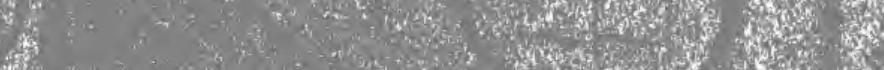



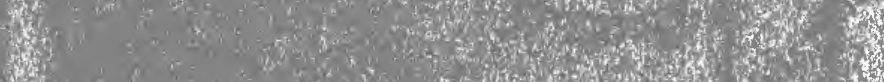



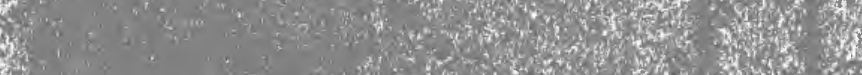

7 it

He:

ting

3it

26:

30

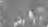

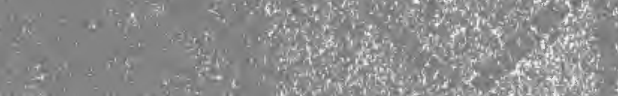

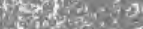

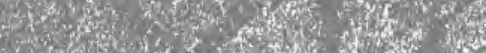

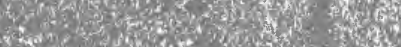

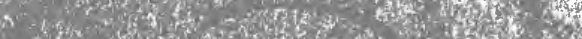

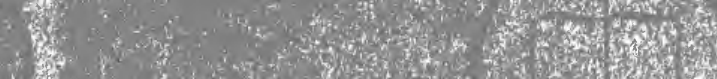

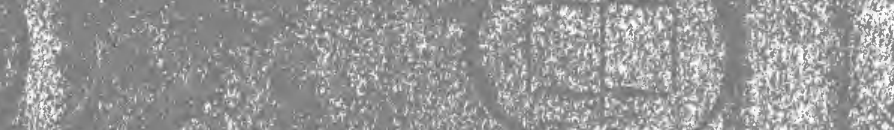

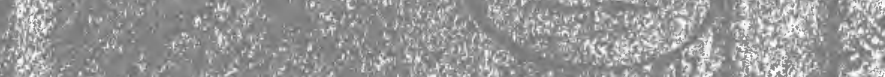
(2)

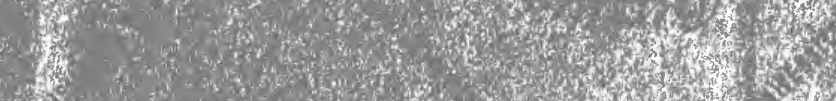

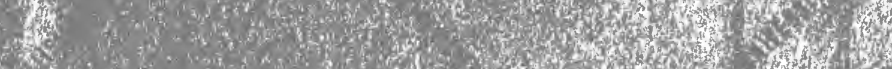

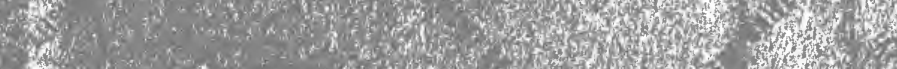

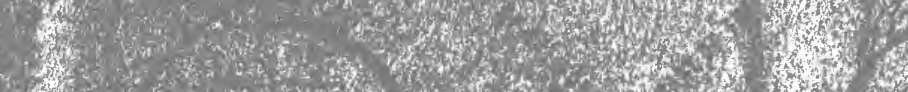
y. x. . .

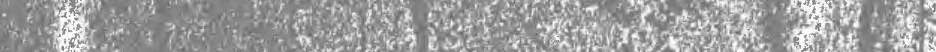

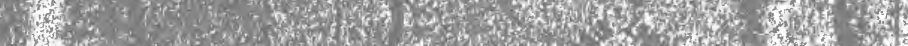

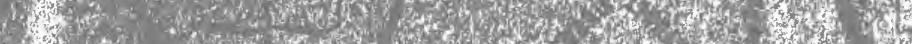
W.7.

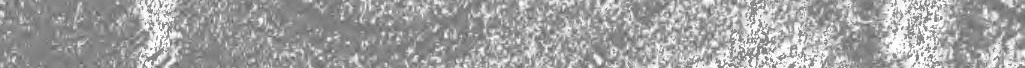








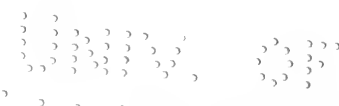

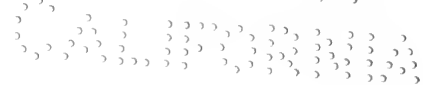





$$
\begin{aligned}
& \text { 方, 3, 3, 3, , , , 3, 3, }
\end{aligned}
$$

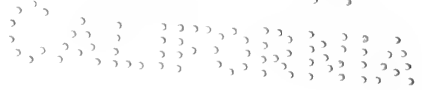




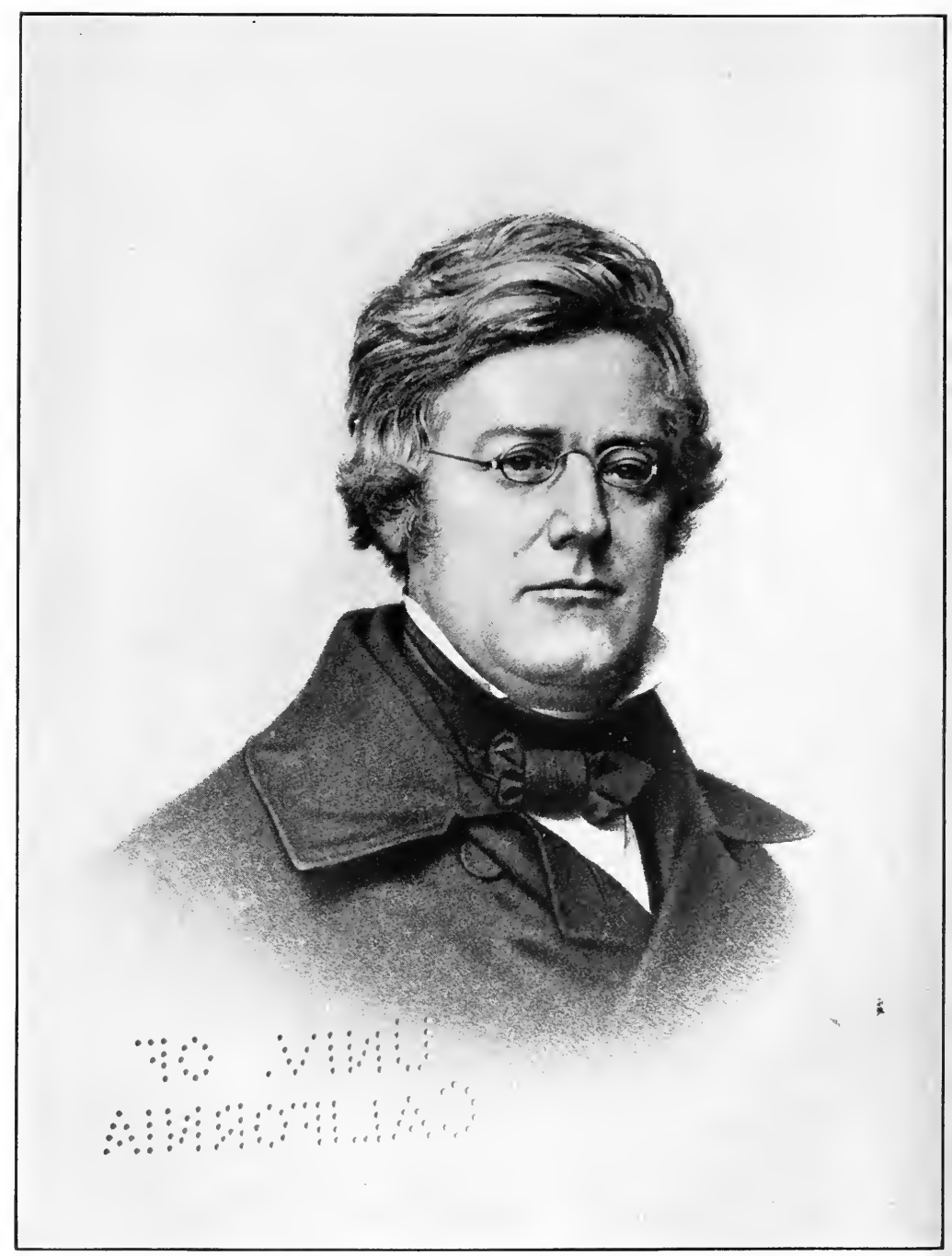

\section{Roberthrgio}




\title{
THE LIFE AND DRAMATIC WORKS OF ROBERT MONTGOMERY BIRD
}

\author{
BY \\ CLEMENT E. FOUST, A.M., PH.D. \\ INSTRUCTOR IN ENGLISH, UNIVERSITY OF PENNSYLVANIA
}

\section{A THESIS}

PRESENTED TO THE FACULTY OF THE GRADUATE SCHOOL IN PARTIAL FULFILLMENT OF THE REQUIREMENTS FOR THE DEGREE OF DOCTOR OF PHILOSOPHY

\section{Tbe Tnickerbocker Dress}

NEW YORK 


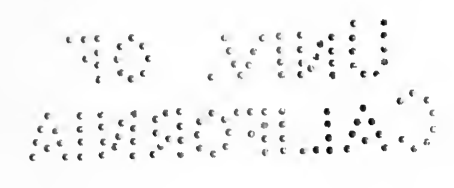

EXCHANGE 


$$
\begin{aligned}
& \text { PS } 1099 \\
& B 5 \\
& 27 \\
& 1919 \\
& \text { MAIN }
\end{aligned}
$$

To

MY MOTHER

MARY COMLY FOUST 



\section{PREFACE}

IT is a matter of surprise that Robert Montgomery Bird has hitherto escaped the biographer. Excepting the brief mention in textbooks and encyclopedias, virtually nothing has been written of a man whose name was once well known to the reading public of both America and England. Cast into cacophonous German, one of his novels found its way to the continent and ran through successive editions. It is, of course, futile to deprecate the verdicts of time as it is unsafe to predict them. It is rather the purpose of this book to set forth the claims of Dr. Bird, such as they are, to rank among American men of letters; and incidentally to explore a character of great charm that made him loved of all that knew him.

In consequence of the total lack of Bird Biography and criticism, the present writer has had to depend solely on first-hand sources. He was fortunate, through the kindness of Dr. Bird's relatives, in having at his disposal all the extant family papers,-letters, diaries, clippings, personal account books, rough and final drafts of novels and plays, and other miscellaneous documentary material of which there is a great abundance. 
Of the four plays in this volume, Pelopidas, The Gladiator, and Oralloossa appear in print for the first time. The Broker of Bogota was first published in Prof. A. H. Quinn's recent volume, Representative American Plays; and although the present text is virtually a reprint of that, it was thought desirable to include the play with the three other chief dramatic works of Bird. In every case, as is stated fully elsewhere, the texts are based on manuscripts in the collection of Bird papers at the Library of the University of Pennsylvania.

It would be gratifying to mention all of the many kind friends who have helped or encouraged in the preparation of this book. But space permits of only brief acknowledgments. Dr. Roland G. Kent, of the Latin Department of the University of Pennsylvania, cheerfully answered a number of queries; Miss Jean Williams of Bristol, Pennsylvania, and Miss Dorothy Stock of Woodbury, New Jersey, aided me with collation and proofreading; Miss Mary Mack, Mrs. Barnes, and Mr. Beach of the Edwin Forrest Home, joined in making my visits at the Home both helpful and enjoyable; Miss Emily Rodney and Mr. Henry Hanby Hay of New Castle, Delaware, hospitably acquaintedme with the scenes of Dr. Bird's early years. I take especial pleasure in acknowledging the aid and encouragement that were mine at the hands of Dr. Bird's relatives. I wish to thank Mrs. John Struthers, a niece of Dr. Bird, and Miss 
Helen von L. Struthers of Philadelphia, for many delightful hours in their home and for the use of their manuscripts. To Mr. Robert Montgomery Bird of Bethlehem, Pennsylvania, the grandson of the author, more is due than can be told. But for his exceptional kindness this volume had never existed. After permitting me an unrestricted use of his grandfather's papers, he generously presented them in toto to the Library of the University of Pennsylvania. To Prof. Felix E. Schelling, LL.D., of Pennsylvania, I am indebted for much helpful criticism, but more for the inspiration of an acquaintanceship that all who have been his students must know; while Prof. Arthur H. Quinn, Dean of the College, not only suggested the subject as a thesis in American literature, but gave without stint of his time and experience in supervising the work.

NoRTh WALEs, Pa.,

June, 1918.

Clement E. Foust. 



\section{CONTENTS}

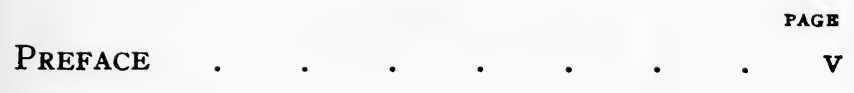

\section{PART I}

LIFE

CHAPTER

I.-Birth AND Parentage . . . I

II.-EDUCATION $\quad \cdot \quad$ • $\quad . \quad$ • $\quad$ I3

III.-APPRENTICESHIP AND FIRST SuCCESS, "The Gladiator" . . . 28

IV.-Forrest and the Later Plays • 50

V.-A Prolific Novelist . • • 76

VI.-Marriage, Farming, Teaching, and

POlitics . . . . .

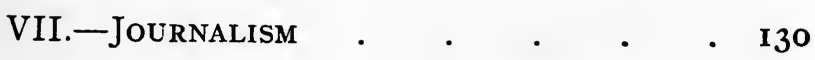



APPENDICES $. \quad . \quad$. $\quad . \quad$ I I I

Bibliographical Note • • • $\quad$ I65 


\section{PART II}

\section{DRAMATIC WORKS}

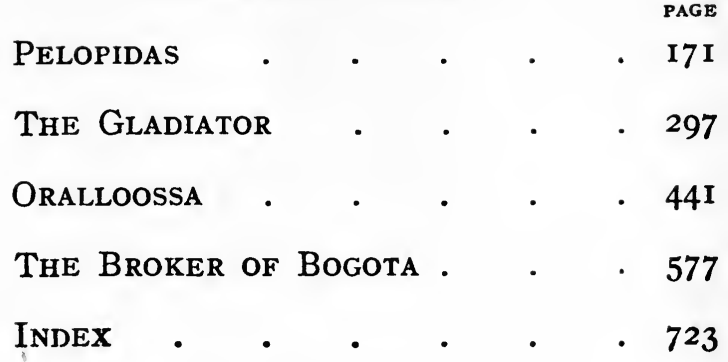


The Life and Dramatic Works of

Robert Montgomery Bird 



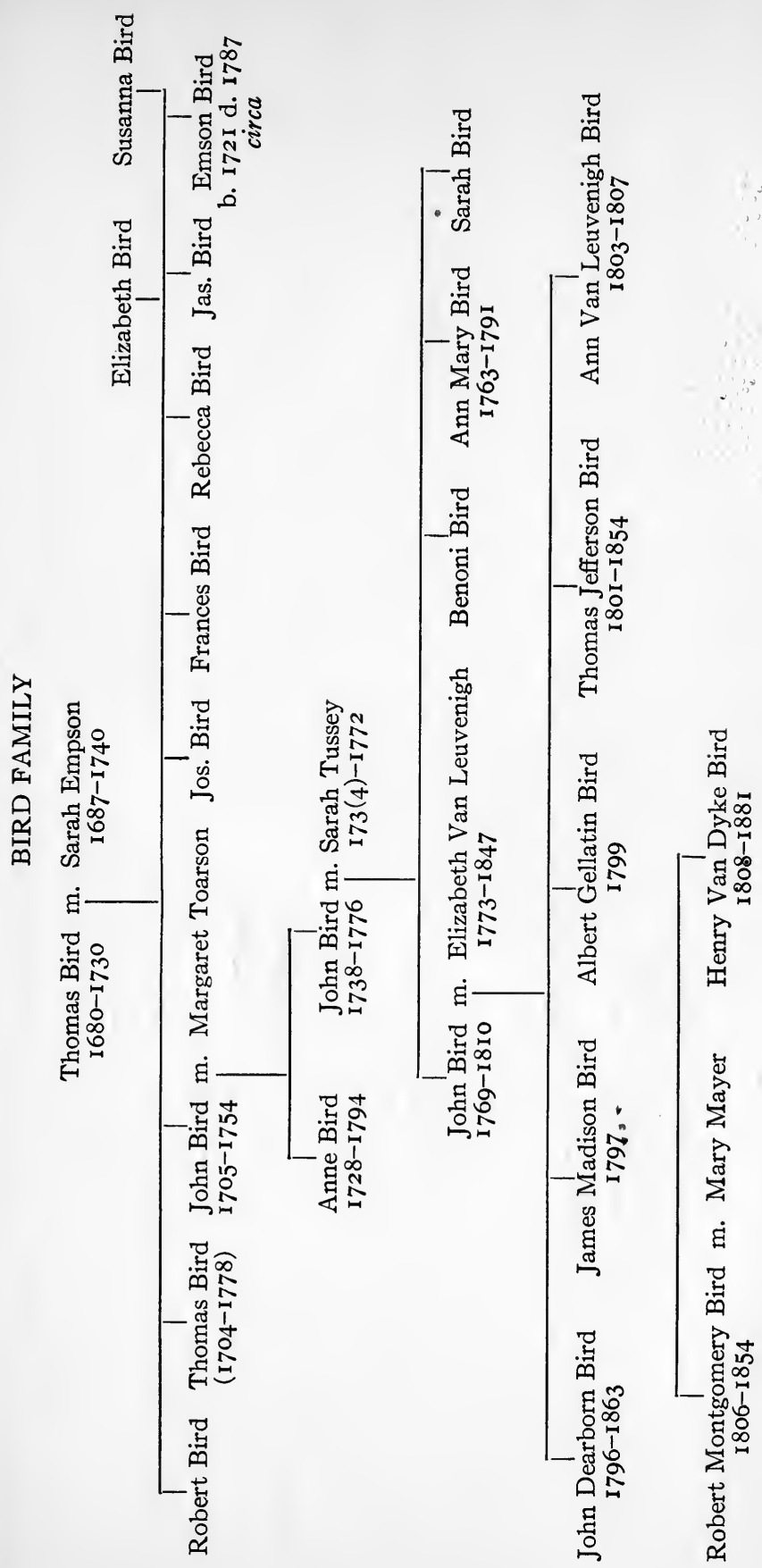




$$
\begin{aligned}
& \therefore \text { ic } \\
& \text { “ic ic } \\
& \text { " } \\
& \text { ic c c c c } \\
& \text { क } \\
& \text { ice ces } \\
& \text { c c c c a t a } \\
& \text { c } \\
& \text { ices cer } \\
& \text { 'ic ic } \\
& \text { c c } \\
& \therefore, c
\end{aligned}
$$




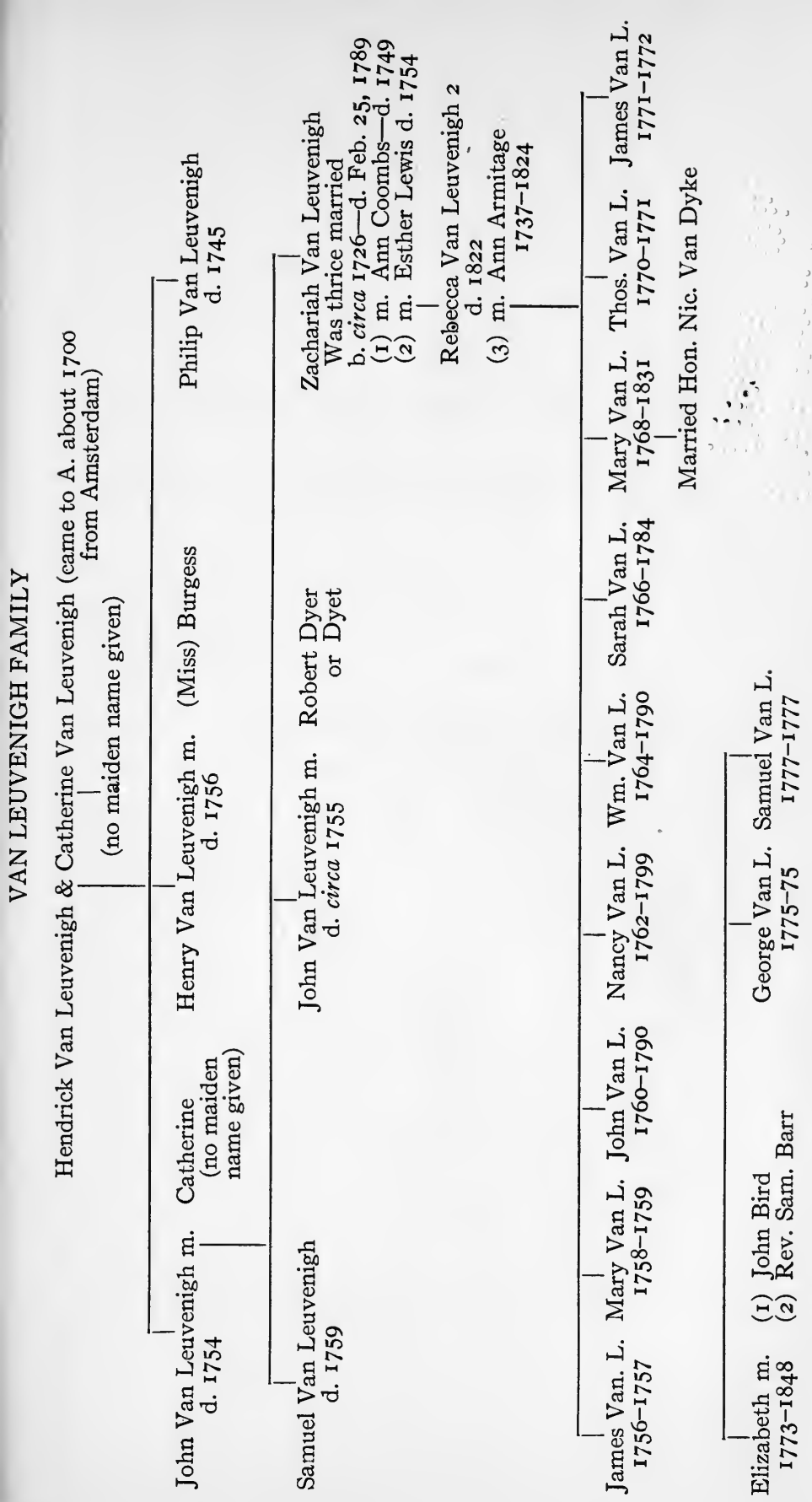


हैंद हैं

cesces

ece ect

'cc ca

$c^{64} c^{2}$

c c c ic

cectect

c धैe

cos ts

ics

ige bes

c c

', 4 


\section{The}

\section{Life and Dramatic Works of Robert Montgomery Bird}

\section{CHAPTER I}

BIRTH AND PARENTAGE

Robert Montgomery Bird was born February 5, 1806, at New Castle, Delaware. ${ }^{x} \mathrm{He}$ was the son of John and Elizabeth Van Leuvenigh Bird, the sixth of seven children. Both parents came of large and stable families that had lived on their Delaware lands for generations. They had owned farms, married well, worthily served their communities, and were reliable, upright people. From them Dr. Bird received a rich inheritance of character and health.

The Birds trace their lineage to an old English family from Cheshire, whither originally they came from Ireland. John Bird, one of its members, won eminence in the time of Henry VIII. He was

${ }^{x}$ The house in which he was born, now numbered 216 , is still to be seen on Delaware Street facing the old "green" or market place. 


\section{LIFE OF ROBERT MONTGOMERY BIRD}

sent by the King, with the royal almoner and a clerk of the council, to the divorced Queen, Catherine of Aragon, to induce her to forbear the name of Queen, "which nevertheless she would not do," the documents expressly phrase it. He was successively bishop of Penrith, bishop of Bangor, and in 154 ) frsti bishop of Chester. At the Restoration, a family tradition avers, two brothers of the name, irembers of Parliament, voted against King Charles with the result that one lost his head, leaving a widow and children in England. The other was banished to America, where his son supposedly began the family line. Certain it is that Thomas Bird settled in Delaware about $\mathbf{1 7 0 0}$ and bought large tracts of land along the Red Clay Creek and in Christiana Hundred. ${ }^{x}$ All that is known of Thomas Bird declares him a man of worth and honor, a leader in his community. He married Sarah Empson, daughter of Cornelius Empson, a judge of the Supreme Court of Pennsylvania, and died leaving six sons and four daughters. These and their children added to farms, already great, land in that loveliest county of Delaware, Brandy-

I In 1713 Thomas Bird bought one hundred acres on the eastern side of Red Clay Creek, New Castle County; in 1719 four hundred acres more "cleared by purchase"; and later 184 acres in Christiana Hundred. For the original survey see the Taylor Papers, New Castle County Warrants and Surveys, in the archives of the Pennsylvania Historical Society, Philadelphia. In the main my account of the Bird and Van Leuvenigh families is based on genealogical tables owned by Mrs. John Struthers of Philadelphia, a niece of Dr. Bird. 
wine Hundred, and passed their quiet lives upon its rolling uplands. Their bones rest in the quaint graveyard of Old Swedes Church, Wilmington. ${ }^{x}$ John Bird 3d, great-grandson of Thomas and father of Robert Montgomery, was born in Brandywine Hundred, April 25, 1769, and was a man of wide interests and varied ability. Although associated with James Riddle, ship-chandler, at New Castle, he filled numerous public appointments and offices. In 1797 he was one of the State's commissioners to fix the boundaries of New Castle, and helped to survey the town, assess the properties, and list the residents. In I80I the New Castle Academy was incorporated and John Bird made a trustee. In 1802 he was elected to the Senate of Delaware, and from I804 to I 809 served as a State representative. He married, February, I795, Elizabeth Van Leuvenigh, and died at New Castle, April 12, I810, leaving six sons and a daughter. Plainly John Bird lived a life, though short in years, uncommonly rich and full; a prompt man of affairs, a pioneer in his home town, who had helped to organize its institutions and incorporate its citizenry. It is of more significance in the light of his son's accomplishment, to note that he was also a man of genuine literary interests. He was a reading man, and knew and loved the masterpieces. It is especially worthy of note that

I John Bird Ist, son of Thomas, was born in 1705 and died in 1754. John Bird 2d, grandson of Thomas, and grandfather of Dr. Bird, was born in 1738 and died in 1776 . 


\section{LIFE OF ROBERT MONTGOMERY BIRD}

he left a manuscript book of verse that he himself composed.

The mother's stock exhibits in like degree character and sturdy worth. God-fearing, honorable, and industrious, they early became influential and rich. From about I700, also, it seems, this family had resided in Delaware, for within a year of that date Hendrick Van Leuvenigh, of Amsterdam, left Holland, sailed to America, and settled in Appoquinimink Hundred, New Castle County. Here on a tract of two hundred and twenty-five acres, which he named "Black Walnut Landing," he lived until about 1716 , leaving three sons as his issue, John, Henry, and Philip. Zachariah Van Leuvenigh, son of John and grandfather of Dr. Bird, was one of the foremost citizens of New Castle. He numbered among his friends George Read, Thomas McKean, a signer of the Declaration of Independence, Chief Justice McWilliams, Judge Finney, and Governor Van Dyke. In 1756 he was commissioned an ensign of the "Upper Regiment of New Castle County," raised for service in the French and Indian War. In I76I his name was affixed as one of the "Principal Inhabitants" of the county to a proclamation of allegiance sent by the Deputy Governor and Council of Pennsylvania to King George III. of England. After the battle of Lexington, on April 19, I775, mounted messengers were sent throughout the colonies to spread the news of victory. At New Castle Zachariah Van Leuvenigh and Stephen 
Spencer in behalf of the town received the missive, indorsed it as proof of delivery, and sent it on its way to the South. He married Ann Armitage, daughter of Hon. James Armitage, May 27, I755. Both lie buried in the yard of old Immanuel Church at New Castle, where throughout their lives they were members. Of their children, Mary married Nicholas Van Dyke, who was to count so much in shaping the career of young Bird; and Elizabeth, successively, John Bird $3 \mathrm{~d}$ and the Rev. Samuel Barr.

It is worth our while to examine this heritage of Dr. Bird. Clearly there was nothing unusual about it, except perhaps the uniformity with which they possessed the fundamentals-piety, enlightenment, stability, and health. John and Elizabeth Bird were of a stock of people who seldom left their names in history or even figured in the newspapers, but who passed quiet, fruitful lives in the daily round of duties that lay next them. For generations they had prospered and were well-todo. On both sides they had supplied their share of leading citizens who struck deep roots in local affairs. Socially, they were a conservative people; physically - at least this was true of the Birds - they were of the race of Anek, tall and strong of frame; and intellectually, as we have seen, alert, steady, versatile, and in one case at least possessed with definitely literary tastes. John Bird, the father of Dr. Bird, found time in a crowded life of affairs to read, and even to write verse. 
But the blessing of a father's guidance Robert Montgomery Bird was not long to enjoy. In the early months of the year I810 the firm of Bird \& Riddle, government navy agents, met with sudden and calamitous reverses ending in bankruptcy and a total loss of the fortunes of both partners. In consequence, on April 12, 1810, John Bird suddenly died of an aneurism of the heart, leaving penniless a wife and seven children. The consequences of a calamity so overwhelming can be easily surmised. The immediate effect was to disperse the family, which was never reunited. The older boys were obliged to go where necessity led them. Mrs. Bird, with her youngest son, Henry, moved to humbler quarters in New Castle, and later occupied for months at a time "The Hermitage," a lovely countryseat of the Van Dykes still to be seen a quarter of a mile west of New Castle. Hers was no easy task. The War of I8I2 was threatening and times were hard; besides in those days few employments were open to women, even to those of education. But a strength of spirit, born of hardship and affection, enabled her to provide for those who were still dependent upon her until her marriage in 18I5 with the man who twenty years before had blessed her first union, the Rev. Samuel Barr. Robert Montgomery Bird, then four years old, went into the home of his uncle, the Hon. Nicholas Van Dyke of New Castle.

In his new surroundings, young Bird was very far from unfortunate. The Van Dyke family 
was one of the oldest, ablest, and stateliest in Delaware. Nicholas Van Dyke, senior, had been a member of the Council of Safety in 1776 , had helped to frame the Constitution of Delaware, and was President of the State from I 783 to 1786 . His son, with whom Bird now made his home, was similarly a man of note. Educated at Nassau Hall, he early won distinction at the bar, had served his State in its legislature, and was successively a member of the House and the Senate at Washington in 1809 and 1817 . General Lafayette counted him "one of the first statesmen in rank whom he knew in America." - He was a man of stern integrity, with views on education and religion that bordered on the severe. A jurist and a statesman of large experience, he was probably, too, an eloquent and incisive talker. And what of the guests that came to dine or spend the night? Many must have been the lawyers and men of affairs who dropped in frequently in busy talk about state matters. To an alert, docile boy like Bird such association must have been most powerfully stimulating and directive. In any case he now acquired a habit of industry and a love of reading that lasted throughout his life. His character, too, was confirmed in the ways of honor. Mr. Van Dyke being a ruling elder and an active member of the Presbyterian Church, it may be supposed that Bird, with the rest of the family, was brought up strictly to habits of church attendance.

Nor was his new environment either bleak or 


\section{LIFE OF ROBERT MONTGOMERY BIRD}

colorless. Dorcas Van Dyke, a pretty, sympathetic girl of his own years, became his confidante and advocate and from the comradeship there flowed to each a permanently ennobling influence. Her character, years afterward, he lovingly set forth in Nanna Howard, in The Adventures of Robin Day. The account depicts, of course, a later stage of their friendship, which, however, had its beginnings at this time. " "The development of her faculties," runs the narrative, "her rapid advance in beauty, grace, sweetness of disposition, -in everything that could warm the heart and influence the pride of a doting father were indeed surprising; and at the time of which I speak-that is when I had reached what was supposed to be the verge of my eighteenth year-she was a creature, being nearly fifteen years old, whom no one could look upon without interest or imagination. She was the loveliest of creatures; and I, who had grown to regard her and to call her a sister, was as proud of her beauty as was my patron, her father himself. . . . It could not be otherwise than that such a being with whom my daily and hourly intercourse was that of a brother, should sooner or later exercise a strong and happy influence, even without knowing it herself, over both my manners and my feelings; and it is to the

× Chapter IX. According to Dr. Bird's wife, Mrs. Mary Bird, The Adventures of Robin Day is autobiographical in several chapters, especially those narrating the youth and education of Robin Day. 
commencement of that influence, more than to the remonstrance of my patron, that I date the first improvement in both. So true is it that the silent, and even unsuspected influence of woman sways the heart more strongly to virtue and manliness than the wisest admonitions of the sages." When she was married years afterward on Oct. 6, I824, to Charles Irénée Du Pont, Lafayette, then visiting America, graciously honored the occasion with his presence, occupying an elevated seat, where through doors and windows kept open for the purpose, the citizens of New Castle viewed both him and the ceremony. ${ }^{\mathrm{I}}$

From these early years Bird gave hints of rich promise, and yet he was not abnormal or eccentric. He had what has been termed a "successful childhood, "going the rounds of fun and mishap eagerly, honestly, and pugnaciously. His wife's account describes him as a spirited, exuberant boy, with even more than the usual push of youth, a leader at cricket, a lover of adventure, and a crack at a bout or a tussle. ${ }^{2}$ Once with another young explorer, it seems, he barely missed drowning on a drifting ice floe in a bight of the Delaware off New Castle. The scenes of the Brandywine, near which Mrs. Bird lived for a time, lay at hand rich in

I American Historical Register, vol. iii., p. 634 .

${ }^{2}$ Mrs. Bird left a manuscript sketch of her husband's life numbering eighty-odd pages, presented with the Bird Papers to the Library of the University of Pennsylvania by the grandson of Dr. Bird, Mr. Robert M. Bird, of Bethlehem, Pennsylvania. 
historic beauty; while the ruins of the old Dutch town, New Amstel, supplied him with endless tales of ghosts and haunted houses. Here was a life in the open, not dull enough to stifle, yet healthfully free from the rush and irritation of a city. Unlike the ordinary boy, Bird was extremely imaginative and acutely sensitive. His imagination, his wife relates, was the source of peculiar enjoyment. His greatest pleasure was to steal from all and stretch full length in his uncle's garden and give full rein to that imagination which had already begun to assert its supremacy. This faculty, discovered and cherished in secret, became the source of his most exquisite enjoyment. $\mathrm{He}$ had been often heard to say that no actual scenes displayed before his physical eyes were more distinct, more detailed, or better remembered. The Van Dyke home stood at the corner of Delaware and Orange streets, New Castle, and had in the rear a deep, narrow garden with arbored walks and flower plots. Hither he often stole to read again and again with the sharp zest of childhood books of adventure, travel, and history. To a mind so swiftly absorptive as his, who can assess the nutritive value of such reading?

There was much, besides, in the old town of New Castle itself to stir and quicken a nature fond of romance. Had there actually been a choice of environment, one could scarcely have been found richer in history and tradition. "Like Salem in New England and Charleston in the South," 
New Castle has always had a flavor and distinction. In colonial days it was a seat of wealth and cultivation; there dwelt the first families of Delaware, 一the Johns, the Van Dykes, the Armitages, the Stocktons, the Rodneys, and the Reads. Since then its position off the main lines of traffic and the swift growth of Wilmington have shut it off from the commercializing effects of trades and industries. In consequence it has kept to a degree the mellow charm of early times. Nor is its past without its stirring scenes. Near its site stood Fort Casimir, built in I63I by the Dutch, who shortly after built the town of New Amstel, captured in 1664 by the English and renamed New Castle. At its quaint court-house William Penn, upon landing in America, October 28, I682, received from the Duke of York's Commissioners the symbols of ownership, a key of the fort, some water, some turf, and a twig. Under its main girders are heavy timber pillars upon which in olden days the hands of manslaughterers were placed while the sizzling iron branded them with the letters M. S. A. "until the fumes filled the room." As a port of entry and a station on the old stage route between Philadelphia and Baltimore, New Castle has seen many men of prominence. Here Washington, supposedly, and Lafayette attended notable weddings. Black Hawk and Jackson have walked its streets, adding each his cluster to the town's traditions. Architecturally the town has long been of interest. Nowhere in America can be found finer types of 
the old colonial home. The stately entrances and hallways, the plain lintels cut like flat arches and set flush with the wall, the beautifully turned bannisters, and secret panels must all have shed upon the sensitive mind of young Bird a pervasively gracious influence. New Castle is a river town, and from the windows of houses along the strand could be seen on a level expanse of the Delaware, steamers and freighters plying their silent ways, as could those of the Dutch, the Swedes, and the English in days of long ago. In such surroundings, then, mellow with tradition and romance, Robert Montgomery Bird dreamed the dreams of boyhood and saw the "visions of grandeur" which pleasantly lingered with him through all the years of manhood. 


\section{CHAPTER II}

\section{EDUCATION}

THE only school in New Castle during Bird's boyhood was New Castle Academy. The original building is still a picturesque sight on the old public green next to Immanuel Church. Although enlarged and modernized, it remains untouched in its main lines-a rectangular structure of brick with numerous windows, a central hall opening on the walled yard behind, a quaint, divided stairway, and neat sunshiny classrooms. From its incorporation in I80I John Bird had been a trustee, and hither young Bird was sent for his elementary schooling.

The methods of instruction at New Castle Academy during Bird's attendance were singularly crude and galling, and were an experience he never forgot. In later years he frequently spoke of the severity of this early schooling. The first aim of the teacher, it seems, was to break the spirit of his charges. A sympathetic sharing of interests and the profit that comes of pleasure were plainly things unknown. The result was a standing challenge on the part of the pedagogue, and a 
series of organized revolts on the part of the school. Though shy and docile to a degree, and of a type of mind that would have drawn nutriment from the plainest fare, young Bird came in for an inordinate share of "correction." Hardly a day passed, his wife asserts, without its bitter tally on his knuckles or his back. In some instances, it seems, this punishment amounted to downright assault. The effect on the sensitive nature of Bird was a feeling of abhorrence so deep that one day he took an oath, on bended knee, runs the record, "to kill his pursuer as soon as he was old and strong enough to do so." This threat he never executed, but he paid the score as unforgivably by conferring on the bully immortality. In The Adventures of Robin Day he has preserved M'Goggin and his ways with suitable embellishments, for those who care to read. The account also vividly depicts Bird's first school days. "The trustees succeeded in engaging the services of a person who, I verily believe, was procured for the sole purpose of testing the efficacy of the brutum fulmen, of subjugating us by main force; for he was an illiterate, vulgar dolt, an Irishman just caught, who professed, as he said himself, to teach nothing but 'r'ading, writin', 'rithmetic, and dacent manners'; although in other respects the very man the trustees wanted. His name was M'Goggin. He was six feet high, and limbed and shouldered like a Hercules; and indeed of such strength and activity, that had he been set at the 
business for which he was best qualified, that is canal digging, I have no doubt he would have cut through the Isthmus of Panama in a month without any assistance. He had an ugly look, too, about the eyes, which besides being the color of a cat's, were overshadowed by a pair of brows of such bigness and appearance that they looked like two stuffed ratskins stuck on with glue; and his complexion was of the hue of sole-leather, plentifully besprinkled with freckles of the size of half-dimes. To add to his demerits, he was entirely incapable of fear, and had such a natural love of a row, that, when informed by the trustees of our character and doings .. . he rubbed his hands with satisfaction, and declared we were 'swate little devils' and that we should get along very well together."

This stage of Bird's career abruptly closed one day when he was found by his uncle, Mr. Van Dyke, in the hands of his sympathizing cousin, who was dressing a bruised and lacerated back. $\mathrm{He}$ was immediately withdrawn from school and for a time allowed to read and ramble as he liked. $\mathrm{He}$ enjoyed a freedom, it seems, that our disciplinarians would have probably called neglect, and yet what a wise neglect! It was a chance to grow spontaneously. In any case, for a boy of Bird's type, aimless play is often the richest pre-experience. His interests, free and unconstrained, are in consequence real and vital. The imagination expands to the new freedom, and self-education, 
which for the gifted is the best education, begins. Thus it was with Bird. Blighting as the effects of the Academy were, reading had become a passion. In 1812 the New Castle Library Company was chartered, and here he obtained books of history, romance, and adventure, reading and re-reading with a zest that must have made them richly nutritive. Now, too, though a boy of but ten or twelve, he began to play with verse and actually finished, according to his wife, a long poem which he hid, but which the tantalizing Dorcas unearthed and read with a flourish to the Van Dyke family. The experience, though it stirred the mirth of Dr. Bird years after, gave pain at the time, and somewhat dashed his ardor. It may possibly have contributed to a distaste to be known as a poet that lasted throughout his life; for these early smarts to a nature so acutely sensitive were sharp and long remembered. But pleasurable to a degree he never forgot were his rambles through the historic scenes of the Brandywine and the ruins of New Amstel, where the yellow brick and coins of Holland were still occasionally picked up. Here dwelt a double charm-the beauty of a smiling country rich in a storied past. And no doubt, too, these frequent jaunts helped to give the large-framed, fair-haired boy that stock of bodily health which brought him at maturity an astounding capacity for incessant toil.

Meanwhile, on May 31, I8I8, the Reverend Samuel Barr died and Bird's mother removed to 
Philadelphia, where she lived with an older son, James Madison Bird. In the year 1820 Robert Montgomery Bird joined them, although still under the guardianship of the Honorable Nicholas Van Dyke, as the following letter shows:

\section{New Castle, June 5, 1820.}

DEAR NEPHEW:

I should have written to you sooner but expected to go to Philadelphia and converse with you about your brother R. M. Bird. The situation of my family has prevented me from leaving home and at present I see no prospect of being at liberty shortly.

As your mother urged so irresistibly her claim to have Montgomery with her, it has been yielded to under the assurance and confidence that he will be under your particular care and direction, and if on any account you discover your directions are not attended to it will be your duty without reserve immediately to inform me that I as standing in the place of his parent may do what my judgment and regard to his welfare may require.

It is essential that he be kept constantly at school and that his growing habit of morning indulgence be at once corrected that he may receive the benefit of his school. His education was at first calculated for a profession to which he always expressed an inclination until I fear too much indulgence last summer suffered his exertions in study to languish and his ideas changed and I was pained to learn from his mother that he could not pursue a profession, but would prefer, some other business. 
The intelligence changed entirely my course and since that time he has been employed at English School. But his attainments I find are yet far below my wishes even for the mechanical business and I therefore direct that he be placed at some good school to be taught again, arithmetic, geography and some branches of mathematics with English grammar and writing. $\mathrm{He}$ should also be occasionally exercised in spelling as every scholar should be an adept in that part of education. As his father was an Episcopalian you must have him taught the church catechism and I particularly request that he may attend some place of worship on the Sabbath. No excuse is to be received for his being out late in the evenings, for bad company which is the bane of youth is almost entirely formed in such a habit. Much instruction and improvement may be derived by reading in the evenings and I hope his taste in that amusement will be cultivated. As I am not authorized to indulge in any extravagance as to dress, I request that the utmost economy be consulted in furnishing his supplies, good plain clothes being all that boys require.

In giving you these instructions I hope for your special attention to the interest of your brother and I shall be much gratified if you can make any arrangement for assuming the duty which is now imposed on your uncle.

Ns. VAN Dyke.

To Mr. JAmes Bird.

This letter throws an interesting light on the boy's life at the time. He was apparently living with his mother and a twenty-three-year-old 
brother, James Madison Bird, but was still under the guardianship of Nicholas Van Dyke, a man, it is pretty plain, who would have no nonsense. It seems, too, that he was addressed commonly as Montgomery, or as it occurs elsewhere, "Monte" Bird. One's sympathy instinctively goes out to the lad who found early rising a bit irksome. Hard afternoons at cricket and a growing boy of fourteen are circumstances that readily account for the fact, and a neglect of geography and spelling as well. He was to be kept in at nights; dressed in plain clothes, but good; and confirmed in the church of his father, the Episcopalian.

In Philadelphia young Bird enrolled in a school kept by a Mr. Pardon Davis, and again, it seems, without serious intellectual damage. The teacher's name, according to his wife, was the only lasting impression. But it was very different with the drawing-school he attended in the neighborhood of Fourth and Chestnut Streets, under the management of a Mr. Coxe. Jemmy Coxe, as he was affectionately known, apparently had the gift, priceless to a teacher, of making his students share his enthusiasm. He had a sharp eye for their hidden strength and idiosyncracies and encouraged them to develop naturally along their line of talent. A genuine lover of boys, he invited them on Saturday afternoons to his home, regaled them with endless yarns, and allowed them to rummage his cases of curios, picked up from land and sea. That Montgomery was a golden child he quickly 
perceived and counted him a favorite. He took him on sketching tours and allowed him assignments beyond his strength in order to stir his effort. Under this instruction Bird gained a facility with the pencil he employed throughout his life. A number of plain and colored sketches dating from this time are extant that exhibit to a degree accuracy, boldness, and smoothness of workmanship.

Within a year, however, Bird left Philadelphia, returned to New Castle, and again enrolled at the Academy with the aim of preparing for college. Of his progress no reports remain, but two old manuscripts in his boyish hand richly deserve mention. One of them is a composition book, written, from the allusions it contains, while he was yet living in New Castle. It comprises five short themes on various subjects- "Effects of the Late Storm," "The Bell of Justice," "The Life of My Puss," "Anecdotes of the Grecian Philosophers," "Anecdotes of the Roman Emperors." There is an Indian story in six parts called "The Whitewashed Cottage of the Susquehanna." Although plainly the work of childhood, there is about this work an ease, accuracy, and invention that bespeak the natural gift. There is evidently an inward delight in the thing, and a directness of phrase that is inevitable. The other manuscript is a "Rhetoric" signed "Robert M. Bird, New Castle, Del. A.D. I822," and is a compendium of the subject abstracted from books or lectures. Bird's 
schooling in the use of language, such as it was, was surely not without its value, and its effects may possibly be found by the ingenious in the effective descriptions of Calavar and The Infidel. But moie enrichment must have come from the pranks and frolics of boyhood and his frank intercourse with many men and things. In the play of a creatively observant mind upon men in action lies the writer's chief equipment. Life is his dictionary and grammar as well. There it is he finds his phrases-in the sports, in the trades and crafts, in the arts and sciences, in the work yard, and the mill. And young Bird, who was so keen a participant in the life about him, must have early absorbed an abundance of such nutriment.

In the meanwhile it was settled that Bird should enter a profession; which one was still undetermined. In any case a course at college was imperative and to prepare he moved to Germantown in 1823 to attend the Germantown Academy. In 1820 Germantown Academy had entered a period of growth up to that date unmatched in its history: In October of that year John M. Brewer, a graduate of Harvard in the class of 1804 , was elected principal at a salary of twelve hundred dollars a year. In return for this, the largest salary the Academy had yet paid, Brewer "engaged to take upon himself the moral government of the pupils as well in the hour of relaxation as in those devoted to study." He introduced a system of rules "based upon the laws which 
govern Harvard College in Cambridge," conspicuous among which were the stress put upon a study of the Scriptures, Sunday attendance at worship, and the public examinations and exhibitions held during the terms. In 1820 there were thirteen students in the upper school and forty-two in the English school. In I 82 I Brewer was succeeded by Walter R. Johnson, who more than any teacher Bird had, helped to shape his aims and character; and it may be added, became a lifelong friend. Also a graduate of Harvard, Johnson had taught school at Farmingham and Salem, Massachusetts, before coming to Germantown, where he became a progressive in educational reform. He led the cause of higher schools in Pennsylvania, wrote numerous articles on the establishment of normal schools, and brought about in large part the Pennsylvania School Law of 1834 . He was later associated with Bird on the faculty of the Pennsylvania Medical College, and at his death in $\mathbf{1} 85^{2}$ was Chemist of the Smithsonian Institution. ${ }^{\mathbf{I}}$

Walter Johnson was just the teacher for a boykeen, virile, enthusiastic - and under his direction Bird made swift advancement. Within a year of entrance he was given the following certificate, written by Johnson himself, in a frank hand and old-fashioned spelling:

Academy at Germantown, Aug. 12, 1824. This certifies that Robert Montgomery Bird of New I A History of the Germantown Academy, Philadelphia, 1910, chapter xi. 
Castle in the State of Delaware has been for one year under my instruction as a student in this Academy and that during this period he has attended to the following branches of study viz: of the Latin Classicks Horace and Cicero de Republica; of Greek Classicks, Graeca Minora and Homer's Iliad; Mathematics, Euler's Algebra and Legendre's Geometry; Elements of Logick; Stewarts Philosophy of Mind; Elements of Chemistry; English Composition in prose and verse and translations into Greek and Latin Languages. His general deportment has been correct and exemplary, his habits of study unexceptionable and he this day leaves the institution with a distinguished literary rank among his fellow-students.

\section{Walter R. Johnson, Principal. ${ }^{x}$}

This "distinguished literary rank" Bird deserved in no merely academic sense, for he was already placing his verse in local periodicals. A poem is said to have been written, his wife states, "at the age of seventeen and Dr. Black has seen verses in a newspaper when he was about twenty that he acknowledged to be his. By comparison of the manuscript with letters it is probable some of the pieces published afterward in Snowden's New Monthly Magazine were written at this early date, for his handwriting was very inferior to what it became some years later when it obtained the character that distinguished it."

${ }^{x}$ See the Bird Papers, Library of the University of Pennsylvania. 
During the year at Germantown Bird had settled the matter of a career and chosen medicine. Accordingly, in August of 1824, he removed to Philadelphia and took rooms with a Mrs. Allen, Number 62 South Sixth Street. Here, it chanced, a young student from Kentucky by the name of Black had also taken quarters. Of like profession and tastes, an enriching intimacy formed that lasted throughout their lives. Years after, in March of 1854 , Dr. Black thus described to Mrs. Bird his friend's appearance at the time. " $R$. $M$. Bird was then eighteen. His appearance was very prepossessing. $\mathrm{He}$ was tall, slender, very fair and youthful looking, and had a Byronic cast of countenance. He had written a good deal of poetry and some verses he [Black] saw that had been published a year before without his name." The summer of 1824 found Bird with a number of other young students in the office of Dr. Joseph Parrish, the well-known Quaker physician and friend of Whittier, who launched on their career so many young doctors of the day. $\mathrm{He}$ also entered a druggist shop for further practical drill. In the fall of 1824 Bird matriculated in the Medical School of the University of Pennsylvania and at the College of Pharmacy. The preservation of all his course cards enables us to track him through his entire course under Dr. John Redman Coxe in Materia Medica, Dr. Philip Syng Physick and Dean Horner in Anatomy, Dr. Robert Hare in Chemistry, Drs. William Gibson and George 
McClellan in Surgery, Drs. James and Dewees in Midwifery, and Dr. Chapman in Clinical Practice.

It was while a matriculate at the University that Bird may be said to have begun his career of authorship. Doing most easily what he did best, he compassed, in addition to the work of the course, a surprising amount of reading and writing. Two large quarto books dated $\mathrm{I} 826$ and $\mathrm{I} 827$ attest the range and thoroughness of his reading. In them are copious quotations and summaries from the works of some twenty-five Latin, English, and American writers. A striking line or favorite verse he copied off; while the plays, chiefly Elizabethan, he summarized and reviewed. $\mathrm{He}$ was very frank in criticism where he thought criticism was due. The Maid's Tragedy, of Beaumont and Fletcher, for instance, he thinks "ill-digested and unsatisfactory. The characters are insufficiently developed; the incidents made little of; and the sentiments carelessly and tamely expressed. Everything wants point; nothing is made the most of; and despite the commendations of the editors, I look upon this play as highly defective, neglectfully written, and, in general, inferior to most of Massinger's plays." Philaster, he considers "in many respects a very excellent play." Of The Beggar's Bush he says, "This is a busy plot, and well managed-though not half so well as it deserves. There are few striking scenes, a poor, tame, and neglected Dialogue. There is something comical in the beggar's election, and the speech of 
their orator, Aiggen, and of Bigg, a candidate, who promises to be a tyrant if they choose him." And so he goes on with twenty-four other Elizabethan plays. Besides this reading he was also planning works of his own. In the earlier book of $1826 \mathrm{I}$ find a list of fifteen subjects for short poems, of which at least two, Saul's Last Day and The Death of Meleager, were completed by 1827 and published in November and December of that year, with other of his verse, in The Philadelphia Monthly Magazine. A total of seven poems appeared in the same periodical within three months, October, November, and December. A manuscript tragedy in five acts, entitled The Cowled Lover, is dated June, 1827; another, Caridorf, or The Avenger, August, I827. To this year also belongs a manuscript comedy, with its scene in Philadelphia, entitled News of the Night; an incomplete domestic comedy, 'Twas All for the Best; and possibly other fragments. A consideration of these plays will be given along with that of his other apprentice work.

Deserving mention, too, are. Bird's student friendships, for with them his earlier novels have a close concern. Through Dr. Black, Bird met another young Kentuckian by the name of John Grimes, who was an enthusiastic student of art. The three took together many jaunts, challenged each other's views, and shared friendly rivalries. On one of these walks along the Wissahickon, according to Mrs. Bird, Dr. Black related a Kentucky story the power of which greatly struck 
Bird. He noted it, visited the scene on his trips west, and later used it as the basis of his romance, Nick of the Woods. Twice he made visits to the Delaware Water Gap, the second time in June of I 827 with Black and Grimes. Here they camped, rambled, and sketched. Among the friends they made was a young artist of the day by the name of Birch, and between them all a friendly sketching bout ensued. This region and these episodes he incorporated in his novel, The Hawks of Hawk's Hollow.

On April 6, I827, the Medical School of the University of Pennsylvania graduated a class of I3I in Musical Fund Hall, Philadelphia. Among them was Robert Montgomery Bird of the State of Delaware, who wrote for a thesis a treatise on consumption entitled Phthisis Pulmonalis. A minute study of its contents belongs to the history of medicine, not of literature. That Bird should have shared the superstitions of his time is to be expected, and, in this respect, he is neither better nor worse than his age. 


\section{CHAPTER III}

\section{APPRENTICESHIP AND FIRST SUCCESS, "THE GLADIATOR"}

AfTER graduation Dr. Bird at once set up as a practitioner and opened an office on Thirteenth Street above Pine, Philadelphia. In those days this section was more rural and open than now, and from his office he could see directly opposite the Deaf and Dumb Asylum on Broad Street, since made a school of Industrial Art. Dr. Bird, we are told, soon won a practice that would have brought him early success, but from the first the physician's life irked him. He disliked its narrowed interests. The constant sight of disease and pain he could not always aid, rasped his sympathies. Besides, he had convictions - absurd he at times acknowledged himself-on the subject of fees; to take them, he felt, was to sell his humanity. Accordingly he kept no case-book, refused to charge, and gave away drugs. But more urgent than all was his call to the profession of letters, which had already usurped his chief ambitions. In consequence within a year he closed his office and relinquished the practice of medicine, which he never resumed, 
although he became in later life a prominent teacher and lecturer. ${ }^{\mathrm{T}}$

It is of interest to review the prospects of a professional litterateur, and of the professional dramatist in particular, at the time Bird embraced the career, that is, about I825. Certainly for a young man of twenty-two without large private means, the step meant heavy risks. Letters as a profession, it is to be remembered, was just struggling into existence, hampered on the one hand by inadequate copyright laws, and on the other by an apathy on the part of the public generally toward American authorship. It is well known how the absence of international copyright worked hardship on writers both at home and abroad. American books were pirated in England, English books in America; and were sold at the cheapest possible rates because their authors had not been paid. The disadvantage to the American writer was the greater because of the prestige of English authorship. "When American readers," says Brander Matthews, "could get a novel of Scott's or of Dickens's for a quarter they felt less inclined to pay a dollar for a novel of Cooper's or Hawthorne's. And the same premium of cheapness tended to increase the sale of Tennyson and to decrease the sale of Longfellow and of Poe. The British author had at least his home market, whereas the American author found his home market pre-empted by

× See MS. Life of Dr. Bird by his wife, Bird Papers, Library of University of Pennsylvania. 
the foreigner." In consequence, men of letters generally were forced to supplementary means of a livelihood; Longfellow and Lowell to teaching, Emerson to lecturing, and Hawthorne to public service. Besides, American authors were by no means received at home as they deserved. There was a servility to English opinion on the part of the critics and especially of the cultivated element that read. Among the latter was a class that judged it a reflection on their tastes to give to native productions a warm approval. The foreign stamp was almost the only means of giving to a book a more than merely local currency. Emerson wrote in his Journal, June I8, I834, "We lean on England; scarce a verse, a page, a newspaper, but is writ in imitation of English forms; our very manners and conversation are traditional, and sometimes the life seems dying out of all literature, and this enormous paper currency of Words is accepted instead." In the words of Professor Lounsbury, we had become "a race of literary cowards and parasites." I

For the playwright these obstacles presented themselves in double measure. The author of a romance or a book of essays had at home at least the protection and the satisfaction of the printed volume. His name was on the title-page, a warrant, in a way, of his ownership. But the dramatist had nothing of the sort. After writing his play, he confined it in manuscript to a single actor

'Life of Cooper, pp. 18-19. 
or manager, who "settled" for it in any way the parties agreed. In Bird's case we know, and in others presumably, these agreements were most careless and unbusinesslike. In some cases copies were made from stolen and mutilated versions of the original, and given by other companies without either the consent or remuneration of the author. ${ }^{x}$ There was of course no law in the matter to define an author's or actor's rights in a play. And yet, unsatisfactory as the situation was, publication was even less desirable. Once printed, a play passed out of the author's control entirely. And there was nothing to prevent any who saw fit from presenting it as often as they liked. Joseph S. Jones, a dramatist of the time, gives as one of his objections to the publication of his plays "that by publication I lost my ownership, copyright giving no protection against representation on the stage." Of course this meant that most of the profits from the drama went to the actors and managers, since the only property of any real value in a play lay in representation. The situation was made still worse by the circumstances already mentioned-the absence of international copyright and a deference to foreign art. Even more than fiction, foreign drama was in demand by the public. Furthermore, it could be given with less expense, since again there was no author to pay. William Dunlap years before found it more lucrative and not less respectable to translate or adapt foreign plays

x See J. S. Jones, Moll Pitcher, Letter from the Author. 
than to write original ones. He frankly made it his business to provide the American stage with English, French, and German novelities. Such then were some of the outer aspects of the profession Bird was now about to enter.

In order to have the ease and comfort of home, he rented with two of his brothers, John and Thomas, a house at I5I South Tenth Street, Philadelphia, over which their mother was asked to preside. Thomas Jefferson Bird deserves mention perhaps for his own sake as well as his brother's. Born five years before Dr. Bird, he early went to sea as a seaman. At the time he made his home with his brothers he was commander of a packetship of the Walker line, plying between American ports and Liverpool. His skill as a mariner was proverbial. There was a common saying on the lips of his crew that he managed his vessel "with the fear of the Lord and a broomstick," in allusion to his piety, order, and cleanliness. To him in later life his brother turned again and again for succor that was ever most kindly given. Thus settled, then, with his two brothers and mother, Bird began a course of the severest study. He read widely and critically in English, French, and Spanish literature. The history and geography of Spanish America were objects of special research, possibly with a view to his earlier romances. $\mathrm{He}$ made numerous maps and sketches of cities, battlegrounds, costumes, and so on. A large notebook of extracts and summaries dated "Feby. 1828 "attests 
the range and thoroughness of this reading. Tonsard's American Artillerists' Companion, Ramsay's South Carolina, Calef's More Wonders of the Invisible World, Josselyn's Nerw England Rarities Discovered in Birds, Beasts, etc., Marshall's American Revolution, are a few typical books thus abstracted. And with the candor of youth he blocked out his career on a grand scale. According to Henry D. Bird, Dr. Bird in 1828 sketched a plan according to which he was to begin as a dramatist, to continue with a series of romances, and to devote his later years to history. Fifty-five plays besides a number of romances and stories, were projected. Of course, the plan is of no deep significance; literature is seldom written that way. It is simply proof of the sweep of Bird's early ambition.

While a medical student, we noticed, Bird had been busily engaged with the pen, and had finished three plays and much verse, of which seven pieces were published in The Philadelphia Monthly Magazine from October to December of 1827 . To this periodical he continued to send work. The January number contains a prose tale and a poem; the May number another story; while between July and September six poems appear. By July, I828, he had completed another five-act comedy, with its scene in Philadelphia, entitled The City Looking Glass. In a prefatory note to the piece he says, "When I commenced the following sheets it was my intention to have written a dissertation upon rascals. . . . I soon turned my eyes to the 
remaining and perhaps the greater portion of Society, the fools, as personages remarkably well suited to shine as inferior and episodic characters in my dissertation." At the time he was also engaged on The Volunteers. On July 14, 1828, he wrote to his brother Henry, "Yesterday I found myself on the Brandywine Battle Ground. It was a good thing for me to be there; for besides delighting me with beautiful scenery it renewed in me the desire to go on with The Volunteers, and furnished me with many hints and clues for my story." Belonging to this year and the next is a mass of unfinished plays and stories, including two complete acts of a tragedy called Giannone, the dramatis personæ, outlines of plots, and scraps of dialogue from at least three other dramas-Isidora, or The Three Dukes, King Philip, or The Sagamore, and The Fanatick. There is the portion of a story called Men of Hills, and much fragmentary verse.

Taken as a whole, this apprentice work of Bird's hardly admits of a difference of opinion. It is frankly without special merit. However, as the work of scarcely more than an undergraduate-all of it was written before he was twenty-three-it is very far from unpromising. The verse is imitative of course, but shows grace; variety, and metrical skill. The lines are simply built; occasionally they rise to the level of beauty. For the bulk of it Bird's most enthusiastic admirer can hardly claim more. Originality, the illumining phrase, the "great accent," even marked beauty 
it does not have. Its best can be easily matched in any book of college verse. The prose tales have little more intrinsic worth than the verse, although more characteristic of his later work. In The Spirit of the Reeds and The Ice-Island there is a suggestion of the facile prose and realism that wins the reader of Calavar and The Infidel. Realism it is rather than reality, because the stories of Dr. Bird much more concern the outer, material detail of action and circumstance than the inner play of motive and feeling that constitutes so true a part of reality. Of this early work it is the dramas that give most promise of what was to come. For a youth of less than twenty-three Caridorf, 'Tis All-for the Best, The Cowled Lover, and The City Looking Glass are remarkable productions. They are large, substantial plays with numerous characters and involved plots, that knot and solve with much naturalness. Even more successful is the spontaneous, clever dialogue. The occasional scraps of blank verse show flexibility and ease. Of course, the plays are full of echoes and not without obvious crudities. The dialogue is frequently too long, the dramatic foreshadowing too marked, the action unwieldy and halting. But taken as a whole, the work is a worthy promise of the greater things to come.

It has been noted that the majority of actors and managers of that day frankly found it to their interests to produce foreign plays that were certain to take and cost nothing rather than to risk 
native drama the authors of which had to be paid. There was one notable exception, who in 1828 gave to native playwrights a splendid chance to win their spurs. Edwin Forrest, the tragedian, was then twenty-two years of age; he had passed a rough-and-tumble apprenticeship as a strolling player through the South and West; but had already made a reputation and considerable money on the stage. He was one of the first Americans to perceive and regret the utter lack of a native dramatic literature, a lack he assigned solely to a want of encouragement. Unlike other managers and actors who frankly avoided the risk of producing American plays, Forrest determined to encourage native playwrights and thus to secure original rôles which should be exclusively his own. Possibly it is true also, as some have charged, he wished to get plays cheaply. In any case he began to offer a series of prizes ranging from five hundred dollars to three thousand dollars as an inducement to aspiring dramatists. The first announcement of the offer he sent to his friend William Leggett, who published it in The Critic of November 22, I828. "To the author," it ran, "of the best tragedy in five acts, of which the hero or principal character shall be an original of this country, the sum of five hundred dollars and half the proceeds of the third representation, with my own gratuitous service on that occasion. The award to be made by a committee of literary and theatrical gentlemen." The committee Forrest 
picked was composed of William Cullen Bryant, Fitz-Greene Halleck, James Lawson, William Leggett, Prosper M. Wetmore, and J. G. Brooks. The first offer brought forth fourteen plays, the prize going to John Augustus Stone of Philadelphia for Metamora, or The Last of the Wamponoags. Afterward at intervals Forrest offered similar or larger premiums, securing in all about two hundred plays. Of these, nine drew prizes, were successfully staged, and have become permanently identified with the history of American drama.

Of the nine prize plays thus obtained by Forrest, Robert Montgomery Bird wrote four, Pelopidas, The Gladiator, Oralloossa, and The Broker of Bogota. Pelopidas, or The Fall of the Polemarchs, finished in the fall of 1830 , is a blank verse tragedy in five acts on a theme from Greek history. Pelopidas, the famous Theban general, with a band of fellow-conspirators enters Thebes at nightfall, where the ruling magistrates who had betrayed their city to the Spartans are banqueting. $\mathrm{He}$ surprises them, slays with his own hand Leonidas, their leader, and thus brings again democracy to Thebes. Forrest's acceptance of Pelopidas is in a way a proof of its worth. At the same time the changes he jotted down and sent to Bird make an excellent critique of the play. There ought to be, he thought, "a little more incident," more "bustling," "more action" in the first three acts. The speeches of Philadas and Archias, 
Forrest judged "too long," and of Philip "much too long." Act III., he went on, required "a better climax," for "there is yet no action"; Acts IV. and V. are to "remain as they are." Finally, Forrest suggested that "Pelopidas should end it quickly"; otherwise, he fears, "'twill be dull."

Though accepted by Forrest and counted by Bird himself his best play, Pelopidas was never staged, since before its production Bird had finished another prize play that apparently better suited Forrest's purposes. How to name the new piece puzzled him. In a letter dated December 3I, 1830, his brother Henry, whom he presumably consulted, advises him to "stick to The Gladiator. It is not only a captivating but popular name, and a character altogether more suited to Forrest's Roman figure and actions." The play was completed by April, I 83I, and accepted at once according to the following letter:

MY DEAR SIR:

The MS of The Gladiator came duly to hand with your letter of Ist instant. I think there can be no reasonable objections against producing your play in June, say, about the 2oth if you think otherwise I will be control'd entirely by your directions and order a postponement of the same until the fall season. In my mind The Gladiator must prove victorious winter or summer to be sure he would not "groan and sweat" so much in cooler weather, but that will be his task not yours. 
I shall be in Philada. about the close of next week when we may discourse fully upon this subject.

Caius Marius on Monday

Evening next.

\section{N. York, 6th May, I83I}

Yours sincerely,

EDWIN FORREST.

RoBert M. BIRD, EsQ.,

New Castle, Delaware.

The Gladiator was thus the occasion of Dr. Bird's introduction to Edwin Forrest. They met, we are told, in the office of Dr. Black, who with Dr. George McClellan, the well-known physician, and father of one of New Jersey's governors, conducted the negotiations. The details of the agreement are stated fully elsewhere. Suffice it to say in passing that for this play, which Forrest gave upwards of a thousand times during the author's life and made a fortune from, Dr. Bird received a single payment of one thousand dollars. ${ }^{\mathrm{r}}$

The Gladiator was first performed on September 26, I83I, at the Park Theater, New York. The principal parts of Phasarius and Senona were taken respectively by Mr. Barry and Mrs. Sharpe, Forrest himself acting Spartacus, the hero. In a personal diary of remarkable interest entitled Secret Records, Bird has left an account of this performance.

' George H. Boker, the dramatist, once said, "If Dr. Bird had managed rightly about The Gladiator, he would have died a rich man." Historical and Biographical Encyclopedia of Delaware, p. 317. 
Sept. 26th at the Park Theatre, New York, The Gladiator was performed for the first time. That evening there fell such torrents of rain as had not visited New York for 15 or 20 years. Nevertheless, the house was crammed, the amount being about 1400 dols. The Park Company is the most wretched in the country. There never was a play more miserably got up, old dresses, old scenes, many of them full of absurdities and to crown all, the performers with but two exceptions were horribly imperfect. If there had been a wish among the managers to have the play damned they could not have taken a better course. . . Next morning Mr. Webbe, of the Courier and Inquirer, made a savage attack upon the piece, saying it was damned. . . . I wonder if Mr. Webbe understands the meaning of the phrase "to thrust an iron into one's soul." . . . The Gladiator was enacted 4 times in New York to good houses; and was more and more applauded every successive night.

The play first appeared in Philadelphia at the Arch Street Theater, October 24th of the same year, with Mr. Forrest and Mr. J. R. Scott in the rôles of Spartacus and Phasarius. Under that date in the Secret Records is the following entry:

Oct. 24th was its first night in Philadelphia. The jam of visitors was tremendous; hundreds retiring without being able to get seats or stands. An American feeling was beginning to show itself in the theatrical matters. The managers of the Arch St. Theatre were Americans, all the chief performers were Americans and the play was 
written by an American. The play was very well got up. . . . It was played with a roar of applause and bravoed to the echo, all which was comfortable enough. Played 4 times in full houses. Forrest is undoubtedly the best man for Spartacus in Christendom; in which his figure and physique show to the best advantage and his voice and muscle hold out to the last.

Scott is a most excellent Phasarius, and makes amends, for not always being perfect to a letter in the text, by going to the business with a will, which tells as favorably for himself as for the author.

Of its performances at Boston, the Secret Records say:

Dec. I4 (I83I). The Gladiator has been performed at Boston and with good success. I have been disappointed in not finding any very lengthy or judgmatical reviews, particularly as the Boston critics have a pretty good opinion of their own abilities.

Such are Dr. Bird's unpretending accounts of his first success as a playwright. But the critics were unanimous in enthusiastic praise. The New York Evening Post said: "The new tragedy of The Gladiator was last evening performed at the Park Theater, in this city for the first time, to a very crowded house. The term 'overflowing' applied to the audience could scarcely be considered metaphorical; for so over full was the pit that a number of persons were literally forced upon the stage by the pressure of the throng. The play was listened 
to throughout with great attention and interest, and on the falling of the curtain, the decision of the audience in respect to it was unequivocally spoken in long continued and thundering peals of applause. It is scarcely possible for a drama to meet with more decided approbation than was bestowed on The Gladiator. A more attentive, and apparently a more engaged audience, we never saw. Throughout the course of the whole entertainment, not a single sign of disapproval was given; and frequently applause, bursting out involuntarily from a part of the audience, to the interruption of the action of the piece, or the passion of the speaker, was immediately checked and subdued by the rest, so that no line might be lost, or the effect of no incident impaired. . . . At the conclusion of the piece, the whole last speech of Spartacus was utterly inaudible by reason of the clamorous applause and when the curtain fell, the theater was literally shaken with the energetic demonstrations of pleasure given by the spectators." The New York Standard said of it: "To us it was a treat of no ordinary interest; we felt-and enjoyed the feeling with pride and satisfaction - that The Gladiator was creditable to the genius, to the taste, and to the literary enterprise of the American people; and we feel no hesitation in putting it down as the best native tragedy extant." The New England Galaxy of Boston said in its issue of November 19, I831 : "During the past week we have been favored by Mr. Forrest with the greatest novelty that could 
be presented to an American audience-a genuine tragedy of native birth. We shall at once be understood as referring to the new prize piece, The Gladiator, written by Dr. Bird of Philadelphia. It is with a feeling of honest pride that we refer to this production; for after the numerous shocking abortions to which our playwrights have within a year or two called the public attention, we cannot but hail with peculiar satisfaction the appearance of a regular, well-constructed, wellwritten, five-act play, which is fairly entitled to notice in the dramatic annals of the day, and forms an era in the literature of our country." The Boston Evening Transcript commented on its language: "It is replete with beautiful passages and noble sentiments. The language is pure, and often highly poetical if we may trust our ear, and the few excerpts made by our contemporaries of $\mathrm{New}$ York and Philadelphia, from the manuscript, the tragedy not being in print." Of course the Philadelphia papers were proud to own their dramatist. "The author has shown," ran The United States Gazette, "not only a knowledge of effect, but a keen perception of the emotions of the human heart, and poetic talent of a very superior grade, in working up the piece from the slender materials furnished by history. He has entered with facility into a Roman expression, which never deserts him throughout. We are not disgusted by detecting the modern masquerading in an ancient garb. This beauty, with the pure classicality of 


\section{LIFE OF ROBERT MONTGOMERY BIRD}

the imagery, renders the piece as attractive to the scholar, considered as a literary production, as the vividness and intensity of interest delight the general audience." While Charles Durang relates of the first Philadelphia performance: "The entire male portion of the audience rose to its feet and gave at least nine cheers. I never saw in my experience any theatrical applause so wildly and impulsively given; and so it went through the land." $x$

The Gladiator is a blank-verse tragedy in five acts on a classic theme. The play opens on a street in Rome where some gladiators, Phasarius among them, observe the city's desertion. Her generals are off to war; her populace is idle; while they must amuse it by shedding each other's blood. Phasarius outspokenly resents his bondage, and darkly hints at revolt. But he is silenced by the appearance of Bracchius, his master, who tells of a Thracian athlete, "most desperate and unconquerable," against whom he is to be pitted. Bracchius fires the blood of Phasarius with glowing accounts of his rival, and sends him to his exercise in a fighting mood. Meanwhile, Lentulus arrives with his Capuan gladiators and his famous Thracian, Spartacus. Spartacus had been a shepherd when through the treachery of a companion in the Roman wars he was captured, sent to Capua, and sold. Now brought to Rome in chains, he sulks,

× Durang, C., History of the Philadelphia Stage, III. ser., chapter xvi. 
refuses to take the oath to fight, pines for his wife and boy, and for his Thracian cottage. When to his joyous astonishment he spies them, whom he thought dead, among others that Bracchius has brought, the cloud goes off his soul, and he takes the oath to fight if they be restored to him. 'So Lentulus buys of Bracchius Senona and her boy. Soon after a magnificent spectacle is arranged in which two hundred pairs of athletes are to fight; and after them, the survivors in general combat. But during his days of practice Spartacus has sown the seeds of revolt among the gladiators, who are primed to respond at his beck. The day of the games arrives; the amphitheater is thronged with the wealth and beauty of Rome; and over all Crassus, the prætor, presides. But Spartacus again sulks, refuses to fight two antagonists sent against him, but a third he crushes to death. At last Phasarius confronts him. For a moment the brothers stare in amazement as they recognize after years of separation, and throwing down their arms, defiantly refuse to fight. When the Roman cohorts are sent in, the gladiators rise in a body, attack the throng, and cut their way to freedom. To capture the insurgents Crassus puts in the field six legions, but Spartacus has mobilized his forces and planned a set attack. After Crixus with his Germans deserts him and is cut to pieces by the Romans, Spartacus sets upon the Consular army, routs it, and captures Julia, niece of Crassus. Spartacus now shows a finer side of his nature by 
a chivalrous refusal to allow Julia to become the mistress of Phasarius, who in a huff also goes his own way, and returns, alone of his army, a repentant man. Finally Spartacus is played false by pirates whose ships he has hired for flight, and, learning that Senona has been killed, makes his way to the prætorium where he dies fighting desperately to slay Crassus.

A number of reasons combined to make The Gladiator effective, first of all the character of its hero. A finer type of elemental man than Spartacus hardly exists in literature, a perfect union of the primitive virtues, physical prowess, great courage, strong passions, and withal a heart of kindness. It is this range of qualities in the man that strikes one as he reads. Capacity for fury and brute strength we of course expect-in gladiators, but in Spartacus there is vastly more. His qualities of leadership are early shown by the regard he inspires and holds in Anomaiis, Phasarius, and his men; by the reserve and balance of his judgment. His nature is also humane and chivalrous. His relations with Senona are ideal; while the captive Julia finds him her staunchest protector. And like most men of action he has the power of uttering great things. "What is your name?" asks the haughty Bracchius. "Misery!" he sadly replies and later in the play observes,

Nature

Makes fewer rogues than misery. 
In addition to the splendor of the character was Forrest's perfect fit in the part. It was essentially melodramatic, and required voice, passion, and strength rather than finesse or subtlety. Forrest was a perfect embodiment of Spartacus; in consequence his acting was swift, sure, and instinctive. Of course it is true, as the English reviewers pointed out, that in the prominence of this one part lay a defect. It was so central and dominant that it draws the strength from the others, who seem but faintly sketched. Scenes where Spartacus is absent are inclined to flag in interest.

Again, the literary quality of The Gladiator struck critics and spectators alike. The blank verse is uniformly easy, pleasing, and effective. Bird clearly proved his control of it as a medium of dramatic dialogue. Quotation at length would be tedious, but one passage that drew attention from both English and American critics and is also typical will serve as an illustration. Spartacus describes to Jovius, the Roman centurion, the desolation wrought by Roman arms upon the Thracian valleys. He has spoken of the "ridgy-top of Hæmus" and continues:

\section{In my green youth I looked}

From the same frosty peak where now I stood, And then beheld the glory of those lands Where peace was tinkling on the shepherd's bell And singing with the reapers.

Since that glad day, Rome's conquerors had past With withering armies there and all was changed: 
Peace had departed; howling war was there, Cheered on by Roman hunters: Then, methought, Even as I looked upon the altered scene, Groans echoed through the valleys, through which ran Rivers of blood, like smoking Phlegethons; Fires flashed from burning villages, and famine Shrieked in the empty cornfields. ${ }^{\text {I }}$

Perhaps the chief factor in the triumph of the play was the energy and splendor of certain of its scenes. The meeting of Spartacus and Senona; the return and death of Phasarius; the frenzy of Spartacus at the news of Senona's end, when he finds himself a hunted fugitive "alone upon the flinty earth"; his death struggle for freedom, are some of the situations that shot thrills through beholders. In the great scene where brother pitted against brother recognize each other after long separation, throw down their arms, and tenderly embrace, defiantly refusing to fight, the applause would burst into riot and interrupt the action. Here Forrest as Spartacus stood stripped to the waist, his great muscles flexed and bulging, his veins swollen, his jaws and neck rigid, his breath obstructed, while he calms his brother with a challenge to the throngs:

Let them come in; we are armed.

And in the lines "We will make Rome howl for this," such were the clang-tints and the power of

s Act IV., Scene 3. 
Forrest's intonation of "howl" that it became a catch phrase with boys in the street. Here the Spartacus of Forrest was "the perfection of physical realism." Everywhere the play was given, and it went throughout the land, it won the same delighted, impulsive applause. From the hour of its first appearance the name of Robert Montgomery Bird had a fixed place in the annals of the American stage. 


\section{CHAPTER IV}

\section{FORREST AND THE LATER PLAYS}

THE acceptance of two plays by a leading actor of the day would supposedly satisfy a young man of twenty-five that he had found his bent. Most authors have begun their careers under far less promising circumstances. But it was not so with Bird. In the Secret Records under date of August 27, 1831, he again wears his heart on his sleeve and naively calculates his chances. He quotes from Suetonius, Vite Casarum and with amiable candor compares his own youth to that of "the mightiest Julius" in its fruitlessness and waste. Twentyfive years he has lived in the world and done nothing-" "nothing but hope." Ambitious as he was, his companions swiftly push by him to positions of responsibility and usefulness. There is a great step between the boy of promise and the man of achievement. "I envy no boy his precocity," he goes on, "but a man's is another matter. Congreve began at nineteen and wrote his last play at twenty-five. Sheridan produced The Rivals at twenty-two, and at twenty-five had written The School for Scandal; at twenty-two 
Campbell had published The Pleasures of Hope; and at twenty-four Byron had become as immortal as Childe Harold. Glorious instances these and very ridiculous for me to talk about them." The Gladiator, of course, had not yet appeared, and its fate was naturally a matter of concern. "I wrote The Gladiator just on the eve of my twenty-fifth year; but can have no satisfaction in noting its birth till I can form some augury of the length of its life. To be sure, folks talk as agreeably as they can, particularly those who know the least about it. . . . I am disposed to be sanguine enough; that is my temperament. But I have just been staring hard at the world, and the view chills my anticipations." He then recounts the career of a friend, liberally educated for a profession, who similarly quit it to pursue literature and pitiably wrecked his life. But there were sounder grounds for misgiving. "Our theaters are in a lamentable condition and not at all fashionable. To write for and be admired by the groundlings! villains that will clap when you are most nonsensical and applaud you most heartily when you are most vulgar; that will call you 'A genius, by G-' when you can make the judicious grieve and 'a witty devil' when you force a woman to blush." Furthermore, the freedom of an American author was greatly narrowed. Were The Gladiator to be produced in a slave State, Bird thinks, the managers, actors, and author as well would probably be rewarded with the penitentiary. Finally, the requirements 
for a successful dramatist might well make a beginner pause and shiver. "What a fool I was to think of writing plays! To be sure, they are much wanted. But then novels are much easier sorts of things and immortalize one's pocket much sooner. A tragedy takes or should take as much labor as two romances; and one comedy as much as six tragedies." He then considers some of those requirements-invention, poetic fancy, common sense. "The sanguine and fiery ardor of an Oriental," "the phlegmatic judgment of a German," infinite capacity for feeling, a thorough knowledge of human nature. "He should in short be at once a poet, orator, wit, and philosopher," and able to carry on two operations in his mind simultaneously, "to create and to fancy his creations acting."

In March, I832, Dr. Bird removed with his mother and a trusted servant to No. I40 North Twelfth Street, Philadelphia, his brothers being obliged by business to leave the city. At the time, it seems, he was head and ears in literary projects. His notebooks are crowded with titles and plans for stories, articles, and plays, and with abstracts from a widely miscellaneous course of reading. His personal accounts for the year I 83I show that he purchased during the month of December Tanner's Narrative, Moore's Byron, Fox's Book of Martyrs, Byron's Poems, Duane's Columbia, Prior's Voyages, Sphix's Brazil, South American Travels, Long's Expedition to the Rocky Mountains, Watson's Annals of Philadelphia. During March 
of 1832 he bought Bryant's Poems, a Dictionary of Biography, Gordon's Pennsylvania, The Voyages of Columbus. In February of 1832, he had finished another blank verse tragedy entitled Oralloossa, Son of the Incas. It was submitted to Forrest and at once accepted, Bird's third play to take a prize. The theme of the play he took from the history of Peru during the first half of the sixteenth century in the days of Pizarro. The conspiracy led by Pizarro's nephew, his assassination of Pizarro at Lima, and the suppression of the rebellion that ensued form the historic groundwork of the tragedy. The only fictitious part, Bird states, consists in the introduction of "the imaginary character of Oralloossa, a son of Atahualpa, and of making him the center of action and interest." Two objects, he further states, he had in view, "first, the portraiture of a barbarian in which is concentered all those qualities both of good and evil which are most strikingly characteristic of savage life; the second, to show how the noblest designs of a great man and the brightest destinies of a nation could be interrupted and destroyed by the unprincipled ambition of a single individual."It is worthy mention, though not a surprise, that Bird's least successful play had its root in a moral purpose.

Oralloossa was first staged October 10, 1832, at the Arch Street Theater, Philadelphia, when the rivalry between this house and the Chestnut Street Theater was at its tensest point. At the 


\section{LIFE OF ROBERT MONTGOMERY BIRD}

latter on October Ioth, Charles Kemble made his first appearance in Philadelphia in Hamlet with a cast that included Miss Kemble, Mr. Sinclair, Mr. James Wallack, and the Ravel family. As a counter attraction Forrest produced Oralloossa, assisted by Mr. and Mrs. Hilson, M. J. R. Scott, Mr. Hill, Mr. C. Kean, and Mr. Cooper. Kemble's fame was great, and all who frequented theaters wished to see him. At the same time Bird's Gladiator was fresh in the minds of Philadelphians and won its author a ready hearing for his second piece. Critics had read the play in manuscript and given it sanguine announcements. "For our own part," ran the account in The Evening Post, "we beg leave in conclusion to tender Mr. Forrest our sincere thanks for the pleasure which a perusal of Oralloossa has afforded us-we thank him for having called into exercise such a mind as Dr. Bird's-we thank him for having added to the permanent literature of our country a tragedy, which, whether for the deep historic interest of the fable, the ingenuity of its dramatic construction, the fine bursts of passionate feeling and the sweet touches of poetry with which it abounds, or the general nobleness of the sentiments, and of the great moral lessons it inculcates, has few superiors in the whole range of English drama." Special scenery had been painted by Messrs. Coyle and Leslie. Richard Penn Smith wrote an eloquent prologue. In consequence the theater-going public of Philadelphia was almost equally divided be- 
tween the houses. But favoring as the circumstances were, Oralloossa was hardly a success. It was the case of a play that read well but acted poorly. Forrest was quick to feel its tameness on the boards and threw himself into his part with such desperation that, in one case, he dislodged a fellow-actor's front teeth by his vehement lunge at Don Christoval. Yet, the audience were plainly disappointed. Oralloossa was inferior to The Gladiator in every respect, in plot, incident, dialogue, characterization. In it Dr. Bird repeated the disastrous mistake of effecting a climax at the end of the third act by the death of Pizarro without being able again to rise above it. Lavish with praise as the critics continued to be, Forrest was convinced that the play was unworthy both author and actor, and at the end of the season struck it from his list of acting rôles.

In the spring of 1833 Dr. Bird and Edwin Forrest planned together an extensive trip through the South and West. Their first intention was to include Cuba, Mexico, and parts of South America, in order to study the peoples, the archæology, and the customs of these lands. Dr. Bird carried with him letters of introduction to General Pedraza and Mr. Castillo, a United States Commissioner in Mexico, who were to put him in touch with sources of information. In these countries Bird's interests had long centered. He spoke Spanish, had made a special study of Mexican and South American history, and had laid the scene of his 
last play in Peru. From Philadelphia they first went to Charleston, arriving April I3th. South Carolina was then in the throes of nullification; shops were closed, houses in disrepair, while the populace, divided into nullifiers and unionists, were so ripe for a fight that "a single personal fisticuffing between the two would have led all into a general combat." Forrest was obliged to hasten on to New Orleans to fill an engagement, while Bird visited Savannah, Augusta, Warrenton, Milledgeville, Macon, Columbus, Montgomery, Selma, and Mobile, reaching New Orleans May 6th. It was Bird's intention to write a book of sketches, and each place has left in a diary its accurate impression. ${ }^{\mathbf{x}}$ At New Orleans they encountered an epidemic of cholera which was raging through the South with fearful destructiveness; they therefore abandoned their trip to Central and South America, and headed for home. Under even the best conditions travel in those days was an arduous task. As Bird with pardonable exaggeration says, he "climbed hills, waded swamps, slept six in a bed, fed on corn and bacon, and was often imprisoned in some rascally village by the heavy rains rendering the roads impassable." Through Baton Rouge and Natchez, they reached Nashville June 16th. Here Bird visited his old friend John Grimes, with whom he explored the Mammoth Cave. They were among the first to penetrate its

I The title of the proposed book was Sketches of America, Physical, Moral, and Political, by a Man of Leisure. 
inmost grottoes, and Bird wrote a minute account for The American Monthly Magazine, and for his volume of tales and recollections, Peter Pilgrim. With Forrest once more he went on to Detroit, from which point he made a detour home by way of Niagara Falls, passing "behind the great Falling Sheet of Water to Termination Rock, July I3th." He arrived in Philadelphia the latter part of July. On his return Dr. Bird at once set to work on a Mexican romance and on a tragedy, the scene of which was Sante Fé de Bogotá. A consideration of Calavar belongs elsewhere. The Broker of Bogota, as Bird named his play, was finished by January, I834, submitted to Forrest, and accepted, his fourth play to win a prize. It was first produced by Forrest at the Bowery Theater, New York, on February 12, 1834, and so delighted the great actor with its power and appeal that immediately on his return from the performance he thus wrote to Dr. Bird:

\section{DEAR BIRD:}

I have just left the theater-your tragedy was performed and crowned with entire success. The Broker of Bogota will live when our vile trunks are rotten. You have every reason to congratulate yourself. Will you come to New York immediately upon the receipt of this letter? Start on Friday morning and you will have an opportunity of seeing your last child "in health and spirits." Come! Wetmore is desirous you should come with him on Friday next. Come! I will return with you to Phila- 
delphia on Tuesday. All your friends will be rejoiced to see you-you shall be welcomed with hearts and hands. Come, Come, Come!

Yours ever,

12 Feb. 1834,

EDWIN FORREST.

NEW YORK.

The Broker of Bogota has been counted by many Bird's best play. It lacked the melodramatic qualities of The Gladiator, and required more skillful acting in the minor parts. For these reasons Forrest gave it less often, but it remained a favorite with him to the end of his career. The Broker of Bogota is a domestic drama of real life in its familiar course. Baptista Febro, the broker, a man of ripe years, has long conducted a large business in Bogota. Two traits dominate the man, personal honor and parental affection. In consequence when his son, a weak rather than a bad man, turns to dissipation, he is vehemently provoked and tries reform by cutting him off and disowning him. He thus blasts Ramon's prospects of marriage with a girl whose father objects to a penniless outcast. In desperation, Ramon opens his bosom to Caberero, a cool, dashing villain, of noble blood and brilliant mind, but utterly corrupt morals, and at his suggestion is entangled in a plot to rob his father and thus win Juana. The robbery is committed. By a diabolical juggling of circumstances Caberero turns back the guilt on Febro himself, who, old and confused, stands piti- 
fully helpless before the court. Meanwhile, Juana, Ramon's fiancée, learns of her lover's base timidity in allowing his father's conviction, wrests from him a declaration of Febro's innocence, scorns his offers of marriage, and hurries to the court in time to exonerate Febro. But, meanwhile, another child has brought sorrow on the aged father; Leonor, his daughter, has eloped with a stranger. This circumstance, however, soon turns to joy when the stranger proves a son of Palmera, the viceroy of Granada, who sues for pardon. Added happiness comes to Febro when Juana's evidence puts his innocence beyond doubt before the assembled court. But alas, Ramon in despair, hurls himself from a cliff. The sudden reversal of emotion is too much for the overwrought Febro; it snaps the last cord; and he falls to the floor a corpse. Even in outline the flawless construction of this play becomes apparent. Here is no misplaced climax. Our interest is deftly transferred from situation to situation, from Ramon and Juana to Rolando and Leonor, to Febro's painful trial, to the touching catastrophe. The characters, too, have flesh-and-bone reality. Febro is an actual acquaintance-hale, courteous, plain, sincere, outspoken. In him, the bundle of traits and possibilities that go into the make of a man are shrewdly set forth. In the court scene when Caberero so shuffles circumstances that there seems "neither hinge nor loop to hang a doubt on" of Febro's guilt, the silent eloquence of his innocence 
pleads with a thousand tongues. His alternate sternness and affection, his pitiable helplessness in the hands of Caberero, his labor and sorrow, his final dissolution like so much brittle glass, touchingly proclaim him man with man's infirmities. Second only to that of Febro is the character of Ramon, a slack-fibered youth equally helpless in a crisis, temptation, or despair. In fact, all the major characters have the clean-run lines of actual people. To conclude, for power, tenderness, range of character, searching portraiture, and general acting qualities, The Broker of Bogota deserves a fixed place in American drama.

One other play hitherto not associated with his name requires mention with the dramatic works of Dr. Bird. Metamora, or the Last of the Wampanoags, by John Augustus Stone, was the first of Forrest's prize-plays. It was first given in Philadelphia at the Arch Street Theater, January 22, I830, and was frequently played by Forrest with every mark of favor. John Augustus Stone was a poor New England actor who had settled in Philadelphia and written several plays less well known. Metamora was played again and again and yielded Forrest enormous sums, but poor Stone shared a small part of them, and in a fit of despair, at the early age of thirty, flung himself into the Schuylkill at the Spruce Street wharf, Philadelphia. Where did Stone get his idea of Metamora? Dr. Bird, according to his wife, never spoke of Stone except in terms of extreme pity. At the same time, accord- 
ing to the same authority, both Dr. Bird and Henry D. Bird asserted that Stone took the idea of Metamora from an early drama of Bird's entitled King Philip, or the Sagamore written in 1829 and submitted, among other critics, to Stone. Bird's early play exists only in fragments, and a line for line comparison is impossible, but there is enough to show strong resemblance. But Dr. Bird had more concern with Metamora. Forrest gradually came to the feeling that Stone's play required revision, and before his tour to Great Britain in 1836 , put it into Bird's hands for that purpose. The play was so written, according to Mrs. Bird, that revision was impracticable. In consequence, $\mathrm{Dr}$. Bird wrote virtually a new play differing from the original in dramatis personæ, plot, and dialogue. Among Dr. Bird's papers are still to be seen notes for Metamora, outlines for acts, lists of characters, scraps of scenes, and suggestions. The play thus revised was accepted by Forrest in September, I 836, Bird charging for the alterations $\$ 2000$. The manuscript was always retained by Forrest, notwithstanding repeated efforts on the part of Dr. Bird and his family to get the play. According to Forrest he never used the alterations, and in 1856 had "not the slightest idea where they are to be found." $x$

The dramas of Dr. Bird were among the first from an American pen to appear abroad. On his

I Edwin Forrest to Dr. E. R. Mayer, Bird's brother-in-law, April 15, 1856. 
professional tours through Great Britain Forrest invariably included one or more in his repertoire. On his first tour in 1836 he opened his engagement at the Theater Royal, Drury Lane, the I7th of October with The Gladiator. This with Lear, Macbeth, and Othello, composed his chief roles.

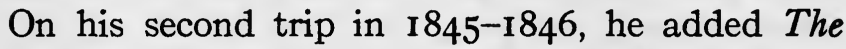
Broker of Bogota. It is not surprising that in England neither of these American plays stirred the enthusiasm they stirred at home. The fact did not necessarily reflect on the plays. Both the theme and treatment of The Gladiator, with its stress on the physical in acting, unfitted it for a strong appeal to a critical London audience of the nineteenth century. It was not exactly what they liked or looked for. Besides an Englishman felt the one true test of an actor's power was Shakespeare. Accordingly, it was not a condemnation of The Gladiator when after Forrest's speech at the end of the play, the audience shouted to him to appear in Shakespearean roles. ${ }^{\mathrm{I}}$ There is, too, a likelihood that the condescension toward American art generally, so marked at the time, was not absent in this instance. It showed itself in the air

x Henry Wyckoff thus described the first London performance of The Gladiator: "Old Drury was crowded from pit to ceiling with an eager and excited audience. All the friends of the popular actors of the day congregated in force. The American minister, and all the fellow-countrymen of Forrest were likewise present. There was silence until Spartacus, the Gladiator, came forward, when a hearty shout of welcome broke forth from all parts of the house. His magnificent person astonished those who had never 
of mild outrage with which they heard Forrest's speech, and their rebuke when he interpreted his ovation as a mark of friendliness to America. On the other hand, many reviewers put their finger with the surety that often distinguishes the English critic on flaws in the play. The dominance of the chief character and the faintness of the others they noted at once. The character of Senona especially, who accompanied Spartacus in his exploits and by his supposed skill in divination prompted some of his most daring exploits, deserved, they thought, more distinction. The weakening after the arena scene they perceived at once. Yet there was much in The Gladiator that the English admired. They thought the subject admirably adapted for scenic representation. The perfect fit of the chief rôle to Forrest's powers won approval. Of course, its great scenes fired its audience abroad as at home. "Indeed," ran a review in The Sun of October 18,1836 , "we have not heard more en thusiastic bursts of applause shake the walls of an English theater since Othello expired with poor Kean. Nor did they omit to

seen him. His rich and powerful voice thrilled all who had not heard it. His earnest, impassioned acting quite electrified the audience. At the end he was overwhelmed with applause and it was plain he had secured a hold on British sympathies, which he never lost. There was a clique present who were disappointed by his success, and when he appeared, at the general demand, to make his acknowledgments, they raised the cry of 'Shakespeare, Shakespeare!'" Reminiscences of an Idler, chapter xxxvii., pp. 376-7. 
note and praise the occasional passages of rare beauty, particularly that describing the Thracian valleys before the Roman invasion when,

“. . . . Peace was tinkling in the shepherd's bells, And singing with the reapers."

While it is true the play did not create the stir Forrest expected and he wrote to his mother that he did not think the English "treated The Gladiator and Dr. Bird fairly," it is true also, that all in all it was favorably received. Of this there is space for but a single testimonial, of many that might be cited.

Dramatic Authors Society

SIR:

LoNDON, Octo. 26, 1836.

I have the honor to inform you that at a general meeting of this society, you as the author of the Play of The Gladiator, were unanimously elected an Honorary Member in token of respect for your Talent as a writer by the English Dramatic Authors.

I have been directed to intimate this to you through your friend Mr. E. Forrest, which I do with pleasure

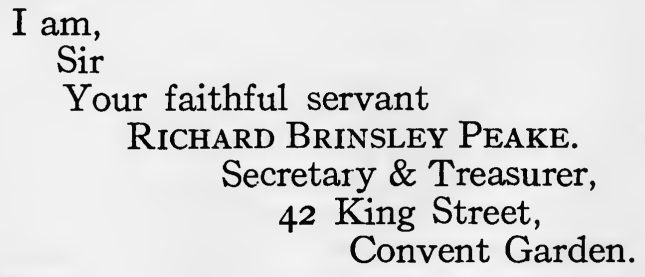

To Dr. BIRD. etc., etc. 
Such, then, were Bird's contributions to American drama. It remains only to consider briefly Forrest's share in their success; his art; his per-, sonal relations with Bird; and to conclude with an account of Bird's views and methods of dramatic composition.

The success of Bird's plays, The Gladiator particularly, owed a large acknowledgment to the powers of Edwin Forrest. For him they were first written, and no rôles in his acting list better displayed his art. Edwin Forrest belonged to what has been called the natural school of acting. Romantic rather than classic, it was empiric in method and built its reading of life rather on observation, intuition, instinct, and practice than on traditional formulæ. Forrest began his career as a strolling player through the South and West. He early learned to heed as the truest tutors his own great depths of feeling and exuberance of passion, his instinctive democracy of sentiment, and men themselves in the original types. Rules and traditions he was apt to ignore. And yet he was not unmindful of his great forbears. From Kean he caught a strong bias toward the melodramatic, from Cooper a fondness for the stately and the statuesque. But men and things were his chief study. He used to walk behind old men, watching their every movement to get the exact tread and mannerism of age. He visited hospitals and asylums, noting all the phases of weakness and death, the features and actions of maniacs. $\mathrm{He}$ 
ingeniously devised contrivances to give to his acting the utmost reality. In the part of Virginius, for example, Forrest for years had the hollow blade of the knife filled with a red fluid which on the pressure of a spring as he struck his daughter spurted like blood from a stab. A lady once fainted away as he played this scene, and realizing that the act was artifice, not art, he never repeated it. Of course, this realism, when within the bounds of art, made for effectiveness. James Oakes recounts a performance of Virginius, where among men and women audibly sobbing there sat near the stage "a fine looking old gentleman with hair as white as snow." In the part where the desperate father kills his daughter, so carried away was the old man that he uttered in distinct tones, "My God, he has killed her!" Afterwards, when Virginius, having lost his reason, comes upon the stage and with a distraught air says, "Where is my daughter?" the old man arose, and looking the actor earnestly in the face with tears streaming from his eyes, said, "Good God, don't you know that you have killed her?" This episode Forrest counted one of the greatest tributes he ever received.

Again, the art of Edwin Forrest had about it a "magnanimous breadth and generosity of manly temperament." Of this the rôle of Spartacus was a superb example. All who witnessed it felt Forrest's burning honesty of passion, his open fellowship, his breadth of sympathy, his large 
elemental nature. His best rôles were ever embodiments of man in his primitive virtue and glory rather than in the refinements of society. With this went hand in hand the spell of his physical magnetism. "His Gladiator," says Alger, his biographer, "in his palmiest days of vital strength was something never surpassed in its kind. Every stroke touched the raw of truth, and it was sublime in its terribleness." Celebrated artists studied his wonderful body, from Gilbert Stuart to William Page, the latter depicting him as Spartacus in the arena, when about to utter his stirring challenge to the throngs. And then Forrest's accuracy and definiteness gave his action distinction and power. Critics joined in eulogizing his reading, which was a "model of precision and lucidity in the extrication of the sense of words. His recitation was as clear as a mathematical demonstration." His voice, naturally deep, rich, and strong, he had given by exercise an astonishing range of fullness and power. Such were the virtues of Forrest's art,sincerity, eloquence, power, an overwhelming animal magnetism. Of course, he had shortcomings,-a lack of spirituality, of beauty, of charm, of subtlety and refinement, which prevented him from wholly winning approval from the intellectual part of the public. He was too inclined, as William Winter puts it, "to dominate a multitude that had never heard anything short of thunder and never felt anything till it was hit with a club." But of these faults we must not make too 
much; they belonged as much to the school and the time as to the man.

A happy stroke it was that brought into intimacy these two men at the start of their careers when each could thus ably supplement the other. It is a regret that a friendship so enriching should have had so brief a term. Edwin Forrest and Robert Montgomery Bird first became acquainted in the office of a friend, Dr. Black, in the spring of I83I, when arrangements were made regarding The Gladiator. They were men of many like tastes, highly regarded each other's talents, were soon to travel together, and so became the closest of friends. Bird counted Forrest the best actor for Spartacus "in Christendom"; while Forrest introduced Bird to his English friends as one of America's first dramatists. Unhappily for both, there was in those days, as we have seen, no copyright law which defined the rights of an author and an actor in a play. Dr. Bird wrote under conditions somewhat like those of Shakespeare's day. An author kept his play in manuscript, and confined it to a single actor or manager. The right of representation, the only property of any value, passed without restriction to the actor or manager, who paid an initial cost, agreed to further payments if a success, and gave the play as often as he liked. The only condition of success, as Bird wrote to George Boker years after, was to surrender every aspiration to literary fame and trust your work as the only means of communication with the 
world to a theatrical company, which more often than not ranted and mangled it in the acting. In Bird's case the procedure was further confused by the fact that his plays were prize-plays, submitted and accepted in competition.

It was the absence of any laws on these matters that led to the break between Forrest and Dr. Bird, and largely induced the latter to abandon dramatic authorship. The exact situation between them seems to have been this. When Edwin Forrest accepted Bird's first play, he made a payment with the understanding that if it were a success Bird should receive $\$ 3000$. A percentage on each representation was also mentioned. As has been noted, it was simply an understanding, not a written contract. For Pelopidas, the first drama, \$1000 was offered. This play being replaced by The Gladiator and not given, a similar offer of $\$ 1000$ was made by Forrest to Bird and accepted. Presumably this was partly in the nature of a prize. The same amount was paid for each Oralloossa and The Broker of Bogota. In short Bird received for the four plays, of which three were performed, the sum of $\$ 3000$. He had borrowed from Forrest loans on notes to the amount of $\$ 2000$, making in all $\$ 5000$. These loans Forrest later tried to collect, giving Bird his first intimation that the balance on the plays was never to be paid. This move on Forrest's part would seem to justify those who have declared his prize scheme simply a ruse to get plays cheaply. 
Furthermore, at Forrest's request, Bird rewrote Metamora, which was accepted in September of I 836, and for which Bird thought due him $\$ 2000$ as he says, "for so much I think it worth." In a word Dr. Bird fixed Forrest's indebtedness at $\$$ I I , 000 of which he had received but $\$ 5000$. To quote his own words, after an itemized statement he continues, "He owes me therefore, $\$ 6000$; though I have no bond, contract, or other written instrument to show that he does." To Bird the situation was the more galling because of Forrest's enormous profits from the plays. His custom was, Bird says, to perform the play "at the first gettings up in New York, Philadelphia, and Boston five successive nights in each place; and, in the second engagements in these towns, so many times more as to be equal, counted with the getting up engagements, to twenty-five or thirty nights in all." $\mathrm{x}$ He thus obtained so many more "crams." Forrest received for the first nights half the gross receipts, for the four remaining nights half the profits; he then made the rounds of the theaters in the South and West, drawing returns almost as large. By a rough but conservative estimate, Bird fixed Forrest's profits on a play for the first year at $\$ 12,000$. And two of Bird's plays, as we saw, Forrest gave off and on to the end of his career.

It was at this juncture, after much unsuccessful endeavor, that Dr. Bird made an appointment in

' See Memoranda among the Bird MSS., Library of University of Pennsylvania. 
his home with Forrest in 1837. His object was to have a settlement as well as to get the manuscript of Metamora, which Forrest had taken with him to Europe. An angry dispute arose. The two parted. When asked by his wife who his visitor was, Dr. Bird replied, "That scoundrel! He is not fit to be in the presence of a lady." From that hour, according to his wife, Dr. Bird lost all interest whatever in the drama, abandoned dramatic authorship, and never after frequented the theater, not even to witness his own plays. ${ }^{x}$

It only remains to set forth briefly, and as far as possible in his own words, Dr. Bird's sources, aims, and methods of workmanship, for we have about

I Among the Bird MSS. I find the following statement of Mrs. Bird: "I have understood that it was customary to add to the announcements of Forrest's intended representations of The Gladiator, in New York, the information that the Author would be present on the occasion. The same gratuitous piece of news may, for aught I know, have been afforded in other places. In regard to such notices I can positively assert that they were altogether without Dr. Bird's knowledge or consent-that he held no direct intercourse with Mr. Forrest for at least sixteen years, the last interview with him being for business purposes in the fall of 1837 after Mr. F.'s return from Europe, when Dr. made a last direct, but unsuccessful effort to obtain possession of the manuscript of Metamora, as well as of the money due by Forrest - that Dr. neither went to New York nor thought of going during the last 18 or 20 years of his life-that during that period he never attended a representation of any of his own plays, nor was inside a theater half a dozen times: indeed, I believe, I may truly say that during that period he was present but once at a theatrical performance, and that was for the purpose of doing honor to a new play of Mr. Boker's-from which he returned home sickened by the heat and crowd." 
these matters the fullest information. Few literary artists have thrown open their workshops with more unreserve than Dr. Bird. Among his papers is a mass of notes, suggestions, outlines, abstracts, diaries, drafts, and fragments that disclose most interestingly his successive steps in composition. One can almost trace the plays from their first impulse scene by scene to completion. Perhaps what first strikes the reader of these papers is the amount of research that preceded writing. Dr. Bird counted it of first importance to catch the exact "form and pressure" of the times and peoples among whom his story lay and spared no pains to get them. The Gladiator, for instance, carried him far into the Latin writers. I find, besides the English works of Hooke and of Ferguson, a detailed list of readings in the works of Florus, Livy, Eutropius, Plutarch, Paterculus, Appian, and Tacitus. $^{x}$ His research into the life and history of Mexico and Spanish America was equally extensive; upwards of two hundred and ten finely written foolscap sheets remain abstracting histories, memoirs, and books of travel. Thus quarried, the incidents were thrown together into a short prose résumé, parted into plot and subplot, and blocked out into acts and scenes, with points marked for

x Among the Bird MSS. I find the following list of sources probably used in connection with The Gladiator: Plutarch, Crassus [8-12]; Livy, Epit., xcv.; Florus, iii., 20; Eutropius, vi., 2; Tacitus, Ann., xv., 46; Paterculus, ii., 30; Appian [De Bellis Civilibus, i., 116-121]; Sallust [Hist., iii., frag. 90, 93, 96, 100, Ior ; iv., frag., 4I]; Cæcilius. 
striking speeches and situations. Abundance of detail was added to give the story the utmost realism, and upon this frame was woven bit by bit the dialogue.

Of dramatic effect Dr. Bird had very definite ideas. "The true secret of effect (in drama)," he says, "consists in having everything as well in details as in general structure epigrammatic or climacteric, the story rising to rapidity and closing with power; the chief characters increasing in passion and energy; the events growing in interest, the scenes and acts each accumulating power above their precursors; the strength of a speech augmenting at its close, and the important characters dismissed at each exit with some sort of point and emphasis." Of course the mastery of this effect involved all those complex requirements that made playwriting so arduous. "The first part of the education of a dramatist," he says, "is that which fits him to be a writer; the second makes him an actor; the third inducts him into the principles of criticism; and he has completed his studies when he can exercise the functions of the three not separately but together. The education of an actor," he goes on, "can only be acquired in the theater, and in a close study of great plays. First he must learn 'stage business,' comprising the mechanical aspects of the actor's art, the management of voice, gestures, grouping, and so on. $\mathrm{He}$ must then learn to act with effect and to see in our great dramas 'what it is that is effective.' $\mathrm{He}$ 
will perceive that certain incidents and situations and certain forms of language are impressive on the boards; while others, perhaps not less interesting and beautiful in imagination, are entirely without point in performance. The great, perhaps the chief, secret of effect depends upon the style of language. . . . The secret is simple: that writer stumbles upon dramatic effect whose characters speak like men; and he fails whose personages declaim like orators and poets. We sympathize in a theater with nothing that is not natural; we even feel the homeliest expressions of passion, when they are like those of the beings around us. ... Shakespeare is a greater dramatist than others because he is more natural. Nature is unchangeable; and at this day . . . Othello speaks in language more akin to that of our fellows than his classic shadow, Zampa. The human expression that breathes from the lips of Lear and Macbeth would render them heirlooms on the stage, had they been otherwise on a level with the other writings of the day."

Finally, the risks and difficulties that beset the dramatist's path, Dr. Bird was ever most frank to confess. Playwriting he counted the most arduous form of literary composition. "What a fool I was to think of writing plays," he says in his Secret Records. "To be sure, they are much wanted. But then novels are much easier sort of things. ... A tragedy takes, or should take, as much labor as two romances; and one comedy as 
much as six tragedies. How blessedly and lazily, in making a novel, a man may go spinning and snoring over his quires." When done, what a risk the play ran in the presentation! In many cases the actors were so crude and amateurish that to entrust them with a piece was to damn it at the start. If discreet, he would place the burden of his play on two or three performers of real power, for most companies had no more. In fine, considering the oblivion, the shabby returns, the risks and difficulties, the exacting and varied requirements that lie in the way of the dramatist, "it is not wonderful few men have the courage to tread it. The marvel is that any are found so daring." 


\section{CHAPTER V}

\section{A PROLIFIC NOVELIST}

ON February 5, I834, Robert Montgomery Bird passed his twenty-eighth birthday. And indeed it must have been with no ordinary satisfaction. There was everything to fill him with pride in the past and hope for the future. He had written four tragedies of which two were soon to reach the height of favor on the stage. His portfolios were filled with plans and scenarios for new plays. With the American public his name alone would have insured further effort an appreciative hearing. He was a warmly admired friend of Edwin Forrest. He had the gift of sturdy health which, however, in a few years was to be his no more. And yet he had written his last play. The next five years Dr. Bird gave to a wholly different type of literature with a productiveness and success that is remarkable.

His change to the novel was due to several causes. First of all, Bird's strength lay rather in prose than in verse as an examination of his early pieces in Snowden's Magazine makes plain. Then, too, his talents, as he says in one of his letters, were 
"of too discursive and diffuse a turn to shine in a nutshell," a fact that doubtless helped to make playwriting the arduous task he found it. The drama of all forms demands brevity and compactness. A more urgent consideration still was the fact that the romance was the literary fashion. Scott abroad and Cooper in America had set the vogue which the young novitiate in letters, if he aspired to prominence, was tempted to follow. Much more than the drama, it afforded a career. The one condition of success for the dramatist, i.e., to have a play accepted by an actor and to confine its use, in manuscript, to him, virtually shut off his hopes as a man of letters. His only contact with the public was through the medium of a company that as often as not garbled a piece in presentation. Hand in hand went a remuneration so scanty that the dramatist was forced to other means of a livelihood. The wonder is that any at that time chose to write for the stage. "Novels," as Bird himself put it, "immortalize one's pocket much sooner."

Dr. Bird's interests, as we have noted, had long centered in Mexican life and history. He had acquired the Spanish tongue, and read widely in its literature and annals. Among his papers are lists of books and scraps of Mexican chronology for a story he apparently intended to call Kevar, or The Knight of the Conquest. It was his intention, on his Southern trip with Forrest, to visit Mexico and study at first hand the peoples and customs. 
Accordingly it is no surprise to find there the scene of his first romance. Calavar, or The Knight of the Conquest was finished in the early months of 1834 , and sent to Carey, Lea \& Co., who thus acknowledged its receipt:

DEAR DOCTOR:

I feel so well satisfied that your book will sell that I think it is better to stereotype it at once. If you agree with me, well-if not, I will send a printer to you. If you think proper you can send copy at once to Mr. Fagan.

I send the Confessions and am

$$
\text { Yr truly, }
$$

R. M. BIRD, EsQ.

H. C. Carey, Feb. 15.

After some adjustments articles of agreement were drawn up April I 7, I 834. According to them Calavar was to be stereotyped at the expense and risk of Carey and Lea. Sufficient copies to meet the demand were to be printed. Dr. Bird was to receive one half the proceeds of sales, after deducting the cost of stereotyping and one half of the cost of paper, printing, binding, and advertising. The agreement was to continue seven years from the date of publication. Semi-annual statements of the sales-which fortunately have been preserved-were to be sent to Dr. Bird. There were other stipulations of minor consequence. The book was copyrighted and given to the public in October of 1834 . 
Calavar is an historical novel with a factual setting of acknowledged accuracy. It concerns the history of Mexico at the time of the conquest in I520 and depicts that full and stirring period from the battle between Hernando Cortez and Narvaez, by which Cortez possessed himself of the city of Zempoalla, to the famous battle of Otumba. The hero is a young Cavalier fresh from the siege of Rhodes, who comes to Mexico to attend his relative, Calavar, as a sworn adherent. He joins the army of Narvaez on the eve of its defeat, accompanies Cortez to Mexico, engages in the thrilling siege of the palace of Axajacatl and the terrible night-retreat from the city, and winds up his adventures on the field of Otumba. In the materials of the story Dr. Bird was both fortunate and unfortunate. Certainly, for the reader of fiction, here was something fresh, remote, and splendid. Southern life, Indian life, English life (as Americans conceived it) had all been treated. But Calavar explored a region rich in romance and hitherto untouched in fiction. Fortunate, too, was Bird's choice of the particular period, the days of the Conquest. A series of events lay at hand ready-made, which were certain to fire the imagination,- - the first push between rival invaders terminating among the burning temples of Zempoalla; the march to Mexico over the field of Tlascula, through the ruins of Cholula, among the volcanoes; the entrance to the royal Tenochtitlan; the battles by day and night, at the palace, in the streets, on 
the pyramids; the death of Montezuma; the ever memorable Noche Trieste, as it is still called by Spanish writers. On the other hand, for many readers the whole subject of Mexico with its heathendom, halfbreeds, and barbarism must have held slight interest. The portion of the hemisphere was at fault. And then Bird was forced at the price of almost infinite toil to get up what writers term local coloring. When Cooper wrote of the forest and the sea, he had only to call to mind the life he had lived, the hazards he had run, and the men he had met, for the furniture of a setting. This Bird had to acquire by poring over Mexican chronicles, histories, memoirs, books of travel, and maps. The preliminary reading for his two Mexican novels was extraordinary in range and amount. I find among his papers upwards of 210 finely written foolscap sheets of notes, chronologies, abstracts, and jottings. Among the books so summarized are Stevenson's Twenty Years' Residence in South America; Bernal Diaz del Castillo's True History of the Conquest of Mexico; Schmidtmeyer's Travels into Chile; De Solis's History of the Conquest of Mexico; Lyon's Residence and Tour in Mexico; Ward's Mexico in 1827; Bullock's Six Months in Mexico; Ulloa's $A$ Voyage to South America; Clavigero's Mexico: There is a list of seventeen titles for additional reading. That Bird was successful in his protraiture both Prescott and Parkman have borne witness.

With its obvious defects, Calavar has some 
merits of first excellence. The historical novel is an exacting form to work in by reason of the double task it places on the writer. He must first of all have a fairly accurate groundwork of facts. Actual men and affairs must be presented as history knows them. But the facts of history are mostly gray, lifeless, and like broken torsos must be pieced out and suffused with being. To do this he must have the constructive imagination. He must lift facts from the dull level of exposition and see "living men in the old documents." These two demands Calavar meets with rare success. In it are set forth with as lifelike actuality as anywhere in fiction the heroes of the Conquest of Mexico. Again the prose of the book entitled Bird to rank as an author. Although at times too full and discursive, it is easy, flexible, when need be dramatic, and vividly pictorial. Bird's descriptions won the critics to a man. Quotation would be tedious and we can only mention the account of the night approach to Zempoalla, the description of Cortez and his trusty band when discovered encamped in the near-by valley, the Night of Sorrow, and the disastrous retreat from the capital. The wealth of stirring episode has been already mentioned. Dr. Bird possessed as his own, it is to be recalled, the playwright's cunning at dramatic narrative. Of the many well-drawn characters in the book perhaps the sharpest or subtlest are Calavar, Amador de Leste, Abdalla, Jacinto, Bordello. One other feature of Calavar deserves mention 
because it characterizes all his novels, its fullness and intricacy of plot.

In the spring of 1834 , before Calavar appeared, Dr. Bird took his only trip to Europe. It was his intention to remain in England some months, possibly a year, to meet the men of letters, acquaint himself with English life, and supervise an English edition of Calavar, a manuscript of which he took with him. Again his many friends supplied him with letters of introduction. Forrest gave him one to James Wallack, who was to introduce him further to "the élite of our calling." Harpers were to send him one to Bulwer. James Lawson, ever the best of friends, gave him a number,- to James Hogg, Scott's friend, "the most remarkable man that ever wore the maud of a shepherd"; to Robert Chambers of the Edinburgh Journal; and to Wilson, "the Professor." With the letter to Wilson went an admonition. "Don't seem to care a d- about him. Talk of eating, drinking, boxing, walking, fishing, anything but letters. Let him rather seek your notice than you his. Manage well and he will grapple you to his heart." Another was to acquaint him with Mrs. Hemans. It is pleasant to think of Bird on this trip, with a past of honor and a future of promise, twenty-eight years old, and, as his passport has it, five feet eleven inches tall, high forehead, light eyes and hair, and a fair full face, sailing off to England on the Pocahontas with Captain West, April 18, I834. Dr. Bird arrived at Liverpool May 13th, he 
wrote to his mother, "after a short but very boisterous passage of only sixteen days from land to land, though of twenty-two from city to city, owing to four days detention in the Delaware and two in the Irish Channel." After a short sight-seeing tour through Chester, the Welsh mountains, "Shakespeare's den," the school cotes of Oxford, and Windsor, he settled in London at No. 3 Adam Street, Adelphi, May 25th. "My lodging house," he writes, "is within one hundred feet of the Thames, my windows look on it; a fine terrace, some forty or fifty above the water, runs along it for about a square. From that terrace, I can see on the left hand, St. Paul's; on the right, Westminster Abbey; without counting a brace of stone bridges with twelve or fifteen high arches each, or towers and steeples in abundance." Thus comfortably quartered, Bird went about the business for which he had primarily come, an English edition of Calavar, and here it was that he met with a rebuff that ever afterward cooled his feelings for English publishers, and to an extent, for English authors. The situation seems to have been this. English publishers of the day would not pay anything for the first work of an unknown author. They would, however, accept it for nothing, and publish it. If the first was successful, a second work would command a fair price. As Bird wrote to the Misses Mayer, "After all my modest unassuming hopes to make a fortune out of the Londoners, they bid very fair to out-Herod Herod, or 
what is the same thing, to out-Yankee Yankee. In other words, as I begin to have the comfortable assurance they will have Calavar from me for nothing, or not have him at all. I hear on all hands how necessary it is that an author should sacrifice his first work, especially a foreign one; and I begin to perceive that I must fall into ranks and do as my betters have done before me. This seems a pretty state of things, indeed, that an author should give a bookseller one book for the privilege of selling him a second; but this is the misfortune of being unknown, as is unfortunately my case. Among the herd of scribblers in Great Britain, notoriety is the only mark of genius for a bookseller; none of these brain merchants will keep a neophyte on pay while he is creeping up hill. But there is this satisfaction in store, that after he is up hill, he can make the rascals pay the.back account. This is my hope." He consulted Bulwer on the matter, who "swears first works are always sacrificed." $x$

It was not alone his treatment from the booktrade that caused a smart. At the time of Bird's visit to England Sir Edward Lytton Bulwer was the literary dictator. He was the popular favorite, "the prince of living novelists." Bulwer had early perceived the revolution in taste and had dispensed with the hero of action for "the hero of observation and reflection, who did not do great things, but who said good things. The sentimental dandies

× Dr. Bird to Miss Mary Mayer, June 25, 1834. 
and high-toned villains of Bulwer's earlier novels captivated all hearts." I Bird met Bulwer, had an interview, and ostensibly by arrangement submitted for judgment the whole first volume of Calavar. After a suitable time and no reply was forthcoming, a request for the return of the manuscript was made; but again no reply was returned. Among Bird's papers, I find three drafts of a second request dated July 7,1834 , varying in tone from polite disgust to bitterest sarcasm. To whichever was sent, Bulwer replied as follows:

SIR,

I am very sorry that my absence from the city has occasioned so much inconvenience to you relative to your work. I much regret that what with the jllness of one of my family and an unusual pressure of affairs, I have not been able to give any detailed inspection to your Ms. But as far as I have been able to go, I have been much struck with the force and vigour of the style and I do not doubt that if the whole resembles the part, it will do you much credit in the publication. Had we both had more time to spare I would have read it thro' more carefully and expressed my opinion more critically.

$$
\text { Yr. ably, }
$$

\section{E. L. Bulwer. ${ }^{2}$}

To one whose patience was already tried, this letter contained additional cause for offense,- the delay,

' Lounsbury, Cooper, pp. 124-5.

2 This letter is among the Bird MSS. in the Library of the University of Pennsylvania. 
the partial reading, the indifference, the moderate praise of the style. It is not surprising that Bird decided to return to America at once "instead of living here expensively and largely for the good of the trade." Accordingly he took passage on the Carroll of Carrollton with his brother Capt. Thomas Jefferson Bird, sailing from Liverpool July 20, 1834 .

The reception of Calavar, if cool at the hands of English bookmen, at home was cordial and appreciative. Within a year of its issue a first edition had sold. The reviewers, without exception, praised it warmly. Poe in one of his articles pronounced it "beyond doubt one of the best American novels." "We do not scruple," ran The Baltimore Gazette, "to pronounce it superior to anything of the kind which has yet emanated from the American press." The Knickerbocker Magazine said of it, "We shall be exceedingly mistaken if the work does not place the author in the very highest rank among the writers of America." Others more enthusiastic could be given. In any case Dr. Bird was encouraged to proceed rapidly with another, and in May, I835, appeared The Infidel, or The Fall of Mexico.

Among the first to read The Infidel was Bird's friend James Lawson. He wrote to Dr. Bird a frank critique which is of first interest in the light of Bird's reply. Juan and Magdalena, Lawson thought, were too passive. The Infidel King and his beautiful sister are fine creations, but our sympathies are not sufficiently awakened in their fate; 
we do not weep over the fall of the Infidel City. And, then, too, there might have been more action. " Of a tragedy, so of a novel," runs Lawson's letter, "action, action, action is the first and last ingredient."' $x$ These points Bird thus meets, in a carefully written draft of a reply: "Your strictures on The Infidel, especially the approbatory ones, are very just. But that confounded sympathy of yours I do not understand. I did not want to make anybody 'weep' over the fall of the Mexicans. All I desired was to illustrate their heroic resistance at their altars and their fires of a scoundrelly foe, whom I desired to paint in his true colors also; as I think I have done. The character of Juan I meant to be 'passive.' In fact, I was drawing the character of a dog I knew once who was a very fine Christian-like animal, for all the hard treatment he had. You certainly are wrong about the 'action, action, action' being as necessary in a novel as in a play. The deepest interest can be drawn from the sufferings of individuals incapable of resisting their fate, and even when they attempt no resistance. Such is found in The Bride of Lammermoor, where the heroine is wax and the hero lead, clay, water, or anything. And that fiction, if you will take my word for it, is the most interesting and deeply affecting ever penned by the hand of man. The actors do nothing; but how one's tears drop over them;-nay over their memory. Five minutes

× Lawson to Bird, May 26, 1835. 
musing over the recollection of that story incapacitates me for writing a day; reading it robs me of all power of composition for a week. However, I know it is needful to make a grand crash in every tenth chapter of my fiddle-de-dees; and my upDelaware book shall have at least one roaring piece of big figure in it." ${ }^{x}$

The story of Calavar terminates on the field of Otumba after the expulsion of the Spaniards from Mexico. That of The Infidel starts at the period when Cortes, receiving a new commission from Charles the Fifth and a great accession of Spanish troops and allies, returns to commence the league that ends in the fall of Mexico. The individual history of Juan Lerma, deftly woven in with the real events of the siege, constitutes the fable. From the same quarry as Calavar, The Infidel shows no signs of imitation or exhaustion. It is as full, striking, picturesque; and with even more passion and feeling. For a narrative description of unsurpassed interest one need only mention the account of Guzman's ordeal on the warrior's stone. To this stone, called the Temalacatl, now lying in the Plaza Mayor of the modern city, captives of excelling prowess were bound by one foot and forced to fight to the death six native warriors, after which, if they survived, they were freed and sent home. The characterization deserves mention in one respect. Cortes himself is a leading character. And the important part he takes gives ample

x Bird to Lawson, June I, 1835 . 
opportunity for the display of the author's powers in that most difficult department of historical novel writing, the correct delineation of real people. The character of Cortes, drawn from authentic data by Bird, is that by which posterity perhaps can best know him. It bears the stamp of actuality and truth. The book contains an array, too large, perhaps, of big characters,-Guatimazin, Cortes, Guzman, Lerma, Lord of Death, Magdalena, Zellahualla. As with Calavar the plot of The Infidel is almost confusingly tangled and intricate. The solution draws on relationships that run back to a previous generation, and are unknown or have dropped from memory. Thus it is with Camarja's strange relations with Juan and Magdalena, and theirs with Cortes.

The Infidel sold rather better than Calavar and in August of 1835-it appeared in May-Carey, Lea \& Company announced a second edition to meet the demand. And yet the sale was not in step with the merit of the book. The reason Lawson hits on in that same letter: "Twixt you and me," he said, "I am not sorry you are done with Mexico. I fear the novel-reading world do not feel the same interest in the semi-civilized portion of our hemisphere, which you entertain. We want something, though not exactly at our doors, yet near us." The justness of this critique Bird acknowledged. "You are right about my Mexican subjects; they are too far-offish and Hebraic for I our Johnny Raws of the States, who know and 
care as little about Mexico as they do about the moon. My success in them has been nothing to compare with Simms's, which I esteem quite extraordinary: I feel very envious about him, but not in a malicious way." While still occupied with the proof sheets of The Infidel, Dr. Bird was also engaged on the "Up-Delaware book" which appeared in September, 1835, as The Hawks of Hawk Hollow, A Tradition of Pennsylvania.

In this story Bird heeded Lawson's advice and laid the scene near his own doorsill in the Delaware valley at the beautiful Water Gap, whither as a medical student with Dr. Black and John Grimes he often went to camp and sketch. The story of the young painter and his chums, and of course the novel's setting are built on these early experiences. The story takes us back to 1760 and concerns an English family by the name of Gilbert, who had settled in the valley near the Gap, its disintegration through the mysterious death of the only daughter, in which Colonel Falconer, the present occupant of the Manor, was questionably implicated, the revenge by the sons of Gilbert, known throughout the section for their desperate character as the Hawks of Hawk Hollow. Woven in is the love story of Hyland Gilbert, who proves to be no other than the legitimate son of Colonel Falconer and his early lost bride, Jessie Gilbert. One is reminded in reading The Hawks of Hawk Hollow of a letter to Bird from Nathaniel Parker Willis, to whom Bird sent a set of his books. "I 
wonder in reading these," it runs, "how you could afford to put so much material into a book. You see I look at it with an author's eye." I The plot is bewilderingly complex. There is a hurry and rush of episode. Again the assortment of big characters is ampler perhaps than the needs of one story,Colonel Falconer, a hard, unemotional, dominating man with a past; Harriet Falconer, a daughter of her father; Hyland Gilbert, a highbred lad with a heart of honor and the instincts of a gentleman; Oran Gilbert, "rough, unswayable, and free"; Catharine Loring, feminine, amiable, lovely. Poe found in the books all sorts of flaws and beauties. "Its style, as we commonly use the word, is at least equal to that of any American writer whatsoever." Its unevenness of course struck him. "Some portions of the book, we surmise, were either not written by Dr. Bird or were written by him in moments of the most utter mental exhaustion," a condition Poe must have shared while writing the review. "It is in many respects a bad imitation of Sir Walter Scott." In the next sentence Poe continues, "Some of its characters and one or two of its incidents have seldom been surpassed, for force, fidelity to nature, and power of exciting interest in the reader." Be this as it may, its demand showed a steady appreciation. By May of 1836 , seven months after its issue, the first statement from Carey \& Lea records a sale of 1860 copies.

Willis to Bird, letter undated. 
In the fall of I835 Bird took another short jaunt through the Middle West, leaving by way of Virginia. On September 24th he writes from Guyandotte, Virginia: "I am in a little village in the extreme N. W. corner of the Cohee land, $150 \mathrm{~m}$. from Cincinnati, and about 170 from Lexington, $\mathrm{Ky}$.; whitherward I hope to be able to proceed in a steamboat to-morrow." On October 6 th he writes from Three Forks, Ky.: "Here I am within seven miles of the Mammoth Cave, and with my old friend Grimes taking a nap at my elbow. We are going to the cave to-morrow, where we expect to be joined by one or two other gentlemen to have a time of it caving, shooting, and fishing together for ten days or two weeks." On October I6th he writes from the steamboat Huntress off Cincinnati: "I am now on the way home, having visited the Mammoth Cave, and resolved to return by the easiest route; for in truth I am tired of rolling in bad coaches over bad roads." The trip was significant for two reasons. Bird and Grimes again explored the great cave to its innermost depths, among the first Americans to do so. This expedition Dr. Bird vividly described in a section of Peter Pilgrim. He also visited the scenes, we are told, that were to figure in his next romance. Besides, it was the last time Bird was to see his friend John Grimes, who died of consumption in the winter of 1837 , holding in his hand a letter of Bird's to the last. Through the rest of his life the name of "Johnny Grimes" was Bird's strongest 
synonym for unselfishness and perfect friendship.

In August of I836 came the anonymous work entitled Sheppard Lee, published by Harpers. The book was so entirely unlike any that Bird had done hitherto that John Frost, his close friend, wrote to him as follows:

Phila., Feb. 2, 1836.

DEAR BIRD,

M'Clellen has taken up an absurd notion that you are the author of a book called Sheppard Lee published in New York last summer. He came to me full of his discovery last night expecting to find that I knew something about it. Knowing that you would be amazed at such an imputation and believing that he would had you to suspect if possible that I had countenanced the [idea] I write to clear myself of even giving the slightest intimation to that effect to him or any one living. I would come to you but I am lame and so write.

Yours truly, J. Frost.

Bird's reply, if he wrote one, has not been found, but there must have been an amusing confession and absolution when they met, as their warm friendship suffered no interruption.

Sheppard Lee might be called a psychological novel. It recounts a series of mental and bodily states through which Sheppard Lee, a New Jersey farmer and an acute hypochondriac, mysteriously passes. Disappointed in love and forced through 


\section{LIFE OF ROBERT MONTGOMERY BIRD}

mismanagement to forfeit the family estate, he goes to a near-by graveyard and proceeds to dig for a mysterious treasure. He strikes rock with such force as to precipitate a trance from which his soul insensibly emerges into the body of John Hazlewood Higginson, an influential colonel. $\mathrm{He}$ is driven in a splendid barouche to the Higginson house in Philadelphia, Chestnut St., south side, etc., and installed into all that went with it,servants, the gout, and a nagging, perverse Mrs. Higginson. With the gout and a shrew on his hands, the poor chap pardonably thinks of suicide. He gradually makes the acquaintance of his aristocratic neighbors, among others, Mr. Periwinckle Smith, whose charming daughter is the cause of insomnia to a polished dandy by the name of Isaac Dulwer Dawkins, Esq. Driven to frenzy by envy and hardship, he resolves upon jumping into the Schuylkill, goes to its banks for the purpose, but beholds I. Dulwer Dawkins already there on the same errand. He recovers the body and regains consciousness to find himself the very same I. Dulwer Dawkins, Esq. He becomes full possessor of his character and effects,-beauty, dash, scores of admiring ladies, plenty of poor relatives, and debts by the hundreds. $\mathrm{He}$ is entangled in countless intrigues, but finally marries Alicia Skinner, the miller's daughter, when-the worse luck of all! - he suddenly inhabits the corpse of her father, Abram Skinner, a soured, tricky pawnbroker with a rebellious daughter. From 
such a despicable carcass the soul of Sheppard Lee devoutly implores release. He looks about for a desirable corpse and finds that of a philanthropic Quaker, Zachariah Longstraw. Three further abodes the wandering soul of Lee occupies, when at last he imagines himself a cadaver under the scalpel of a German student, Dr. Feuertaufel. This scares him back into sanity; he flees; nor does he stop until he has reached his old Jersey farm, which his relatives have been good enough to reserve for him. Here he shakes off his hypochondria and finds himself once more Sheppard Lee.

Sheppard Lee is, as Poe put it, "a very clever and not altogether unoriginal jeu d'esprit." Its incidents are well conceived, and related with force, brevity, and a directness admirably suited to such narratives. Poe, a master hand at such narrative, found fault with "the conception of the metempsychosis. $\mathrm{He}$ (Bird) conceives his hero endowed with some idiosyncrasy beyond the common lot of human nature and thus introduces him to a series of adventures which under ordinary circumstances could occur only to a plurality of persons. The chief source of interest in such a narrative is or should be the contrasting of these varied events in their influence upon a character unchanging-except as changed by the events themselves." Poe further thought it a mistake to leave the reader at the end with the impression that the whole is a dream. His own method, Poe 
thought, would have been better i.e., "avoiding . . . that directness of expression which we have noticed in Sheppard Lee and thus leaving much to the imagination . . . in short, by making use of the infinity of arts which give verisimilitude to a narration-and by leaving the result as a wonder not to be accounted for." Finally, it is to be noticed, the hand of the physician is plainly observable. Doctors play a prominent part. The effects of mental derangement,- the fear, the harping on one thing, the excitement, the nightmare, are analyzed with the technical insight of a physician. Sheppard Lee received from the press the most favorable notices, but never enjoyed a large sale. Its first edition appeared when the book trade, on account of hard times, was in a most depressed condition. Its publishers issued a second edition with the revival of business, which, however, sold hardly better than the first; and as late as 1839 they were negotiating with Lea \& Blanchard to dispose of their interest in the stereotype plates of Sheppard Lee and the printed copies on hand.

In March of 1837 Dr. Bird's most successful story, Nick of the Woods, was published by Lea \& Blanchard. The suggestion for the story, it is to be recalled, Bird had received many years before from his Kentucky friend Dr. Black while they were together on a stroll. On his western trips he visited the scenes of the story and gathered further material. The characters in some instances 
were built on actual people. Ralph Stackpole, Bird tells us in the preface, "is no portrait drawn from imagination. The history of this wild scapegallows, his prowess in the pinfold and the battlefield, his adventure in the beech tree, and his escape from the meshes of the law, with other characteristic events not included in our relation, are recollections still cherished in some parts of Kentucky, and made the theme of many a gleesome story." The story of Wandering Nathan "has a similar foundation in truth; but its origin belongs to one of the western counties of Pennsylvania." Here was a legend sufficiently near home to hold the interest, sufficiently strange to stir curiosity. It delineated that most picturesque character which both Cooper and Simms had drawn on effectively, - the American Indian. But how differently each conceived him! Cooper, of course, has idealized the Indian in such characters as Uncas and Chingachgook. Simms had studied him through books and observation as well, and has given us perhaps the truest picture. "From the day," says Professor Trent, his biographer, "when he saw scores of drunken and naked Creeks lying about the streets of Mobile, he was thoroughly alive to their vices; but from the time of his sojourns in both Creek and Cherokee 'Nations' he had also been fully conscious of their many undeniable virtues." Bird paints the Indian frankly and unreservedly in the darkest colors. $\mathrm{He}$ confessed himself quite unable to share the 
kindly view of the Indian held by other writers. Chateaubriand, Cooper, Marmontel throw a poetical illusion, he thought, over the Indian character. He drew them as in his judgment they existed,"ignorant, violent, debased, brutal." Furthermore, he resented the opinion expressed by $\mathrm{Mr}$. W. H. Ainsworth in his English edition of Nick of the Woods that the book was designed to inflame the whites against the Indians, or to justify the encroachments by the whites on Indian territory. "We confess," he says in a prefatory statement, "the North American savage has never appeared to us the gallant and heroic personage he seems to others. The fact that he wages war-systematic war-upon beings incapable of resistance or defense -upon women and children, whom all other races in the world, no matter how barbarous, consent to spare, has hitherto been, and we suppose to the end of our days will remain, a stumbling-block to our imagination; we look into the woods for the mighty warrior, the 'feather cinctured chief,' rushing to meet his foe and behold him retiring laden with the scalps of miserable squaws and their babes. Heroical? Hoc verbum quid valeat, non vicent."

Rapidly as Bird's novels succeeded one another, he found time also to write for the magazines which were springing up in America during the first half of the century with the utmost variety and profusion. A strong sectional feeling throughout the States tended to multiply the number. Most of 
them, modeled on the English literary journals,Blackwood's, Frazer's, The Edinburgh Review,-had high ambitions and were incessant in their requests upon men like Dr. Bird, whose romances had brought him impressively before the public. Besides, Bird numbered among his friends W. Gaylord and L. Gaylord Clark, James Lawson, Thomas Cottrel Clarke, Charles Fenno Hoffman, Samuel A. Howe, N. C. Brooks, and others. It was inevitable that he should sooner or later be concerned with the periodical, as contributor or owner. Bird's juvenile pieces in Snowden's have already been noticed. Early in the thirties Louis A. Godey, who in July of 1830 had founded his popular Lady's Book, asked Bird for articles, or if he had none on hand "to hammer me out of one of your solid pieces about twenty-five dollars' worth of Literature." In January of I834 appeared a new periodical edited by Henry Vethake, Esq., called The United States Review. It was a quarterly of some 250 pages and was to be concerned, ran the Prospectus, with "the exploits of the historian, the orator, and the poet rather than with those of the mathematician." For the first number Bird was asked to write an article on "Reviewing," and to become a regular contributor. Of course numerous bits of verse, struck off, his wife tells us, in moments of relaxation, appeared from time to time. In March of 1834 "The Beech Tree," a lyric, appeared in the New York Mirror; in January, 1835 , "The China Tree," another, in Knickerbocker's; 
in February, 1835, in the New England Magazine "To Governor M'Duffie," an occasional poem denouncing the Governor of South Carolina who in the nullification squabble called the Constitution of the United States "that miserable mockery of blurred and obliterated and tattered parchment." "An Evening Ode" appeared in Knickerbocker's, February, I 835; "An Address," an occasional poem at the Wood Complimentary Benefit, in The National Gazette, January, I836. Poe had for some time desired Bird to contribute to the Southern Literary Messenger. Other duties made it impossible for Bird to comply. In consequence Poe repeated his request.

RICHMOND, VA., June 7,1836 .

Dr. SIR,

I take the liberty of again addressing you, and of calling your attention to what was not precisely a promise on your part, but a kind of demi-promise made some months ago, in relation to an article for our Southern Literary Messenger. It would be indeed, a matter of sincere congratulation with us, if, by any means within our power, we could so far interest you in our behalf as to obtain something from the author of Calavar. We have, just at this moment, a conspiracy on foot, and we would be most happy to engage you in our plans. We wish, if possible, to take the public opinion by storm in a single number of The Messenger which shall contain a series of articles from all the first pens in the land. Can you not aid us-with a 
single page if no more? I will trust to the chivalric spirit of him who wrote The Infidel for a reply. With the highest respect,

$$
\text { Yr. ob. st. }
$$

\section{Dr. RoBert M. Bird.}

EDGAY A, PoE

One article contributed by Dr. Eird to Kir s ser bocker's in October, I835, is of significance in the history of international copyright. It is entitled "Community of Copy-Right Between the United States and Great Britian." After a short statement of the injustice of the world to authors and inventors generally, he takes occasion to score the copyright laws then in force in America. The act of the third of February, I83I, he points out, extends the privileges of copyright "to any person or persons, being a citizen or citizens of the United States, or resident therein, who shall be the author or authors of any book or books," etc., and to no others. "To be a citizen, or a resident of the United States, is therefore essential, by law, to the enjoyment of the privilege. The restriction is positive, and peculiar to America, which, in it, excels all other governments in rapacity and meanness." From the provision, he thought, a twofold injustice results. In the first place British authors received no returns whatever from the sale of their books in this country. "Walter Scott never received a cent on the sale of his works in America,"

I This letter is in the Archives of the Historical Society of Pennsylvania, Philadelphia. For a list of Dr. Bird's contributions to the magazines see Appendix B. 
although New York did raise a subscription, it was said, of sixty thousand dollars "to rescue Abbotsford from the hands of the creditors, and secure it to the heirs of the great novelist." By far the greater hiardship, however, was wrought upon the American author. Paying nothing to the British aythot the American publisher selected what foreign works he chose, and issued them at a very low price, content to receive the bookseller's profit. An American work, on the other hand, had to bring a price which secured a remuneration to the author as well as the publisher. In consequence the former invariably undersold the latter. As Dr. Bird put it, "It is indeed egregious nonsense to expect an American book to leave the bookseller's shelves, when an English reprint lies by it, of equal merit and one half the price." The burden of the article in brief was that the act of I83I, purified by the removal of the clause above quoted, "would be tantamount in effect to the passage of an international copyright law betwixt America and Great Britain."

As a consequence of this article, in part at least, Dr. Bird received the following letter from Harriet Martineau, urging his aid in pushing a petition regarding international copyright. It was accompanied by a petition, which incorporated many of Bird's views and, it seems, specifically referred to a portion of the Knickerbocker article. ${ }^{x}$

× The petition in part ran as follows: "American authors are injured by the non-existence of the desired law. While American 
DEAR SIR,

LoNDON, Novbr. 8, 1836.

This petition tells its own story,-except that you do not see the signatures. It is very illustriously signed. We hope the names of Brougham, Wordsworth, and Miss Edgeworth will be at the top.

The Americans in London urge that the Authors of the United States shd. petition Congress, - both houses, - to the same effect, at the same time: I have written to most of my literary friends, to rouse them to this. If it could be done, we should we are told pretty certainly have the desired law this session. You see how close an interest you Amern. authors have in our property not being stolen to enrich the booksellers and lessen the value of your works.

If you can do anything in this matter, I am sure you will: not making confidants of any booksellers, but communicating with brother and sister authors.

I make no apology for writing to you on this subject: for we each desire the welfare of science

publishers can provide themselves with works for publication by unjust appropriation, instead of by equitable purchase, they are under no inducement to afford to American authors a fair remuneration for their labors: under which grievance American authors have no redress but in sending over their works to England to be published, an expedient which has become an established practice with some of whom their country has most reason , to be proud. . . . Your petitioners beg humbly to remind your Honors of the case of Walter Scott, as stated by an esteemed citizen of the United States, that while the works of this author, dear alike to your country and to ours, were read from Maine to Georgia, from the Atlantic to the Mississippi, he received no remuneration from the American public for his labors." The Critic, April 21, 1888. 
and literature; and have each a personal interest in the passage of this Law. Believe me, dear Sir,

Dr. BIRD,

Very truly yours,

HARRIET MARTINEAU.

Philada., PA.

Notwithstanding their cause was a common one, Dr. Bird in a draft of a reply to Miss Martineau, January 20, I837, roundly attacks the petition. To his mind, it was singularly injudicious and objectionable; it was too argumentative and exhortatory; it breathed a tone of complaint and reproach. Furthermore, it denounced a respectable class of American citizens, the booksellers. It made a tactless reference to the prejudices of purchasers in "the respective sections of the Union," which was an invasion of our private concerns. $\mathrm{He}$ advises a revision of the petition so that it would be "a petition in fact, - a simple, briefly expressed and dignified claim to a privilege which they think they should be allowed to enjoy."

Two other works require mention with the romances of Dr. Bird. Peter Pilgrim, or A Rambler's Recollections, published by Lea \& Blanchard in October of 1838 , is a collection of tales and experiences gathered on his trips through the South and West. Two of the pieces had appeared in the American Monthly,_- "A Tale of the Snag" and "The Mammoth Cave"; another, "The Extra Lodger," was published in the New York Mirror. 
The most interesting chapters of a rather indifferent collection are those on the Mammoth Cave. Caves had long been a special study with Dr. Bird. With John Grimes he was among the first to explore this biggest of caves, and to set forth an accurate account of its grottoes, pits, and galleries. The rest of the recollections comprises a miscellaneous collection of odds and ends. According to Mrs. Bird, Dr. Bird's health had begun to break and he was obliged to throw together his materials for the volume more hastily than was his wont. The Adventures of Robin Day, his last romance, was published in April, 1839, and was written under stress of great physical suffering. It is a rather loose-woven yarn of improbable adventures. The earlier portion, however, is of autobiographical value; and according to his wife, "embodied a good deal of his own youthful experience at school." ${ }_{x}$

Bird's romances, in America, brought a fair remuneration. His precise returns it is, of course, impossible to fix; but from accounts in his own hand and from the semi-annual "statements" from his publishers some idea can be had of his income. The following table is based upon these semiannual statements, and indicates the number of

x Deserving mention with the romances of Dr. Bird is the fragment of an Indian story entitled Ipsico Poe, the Long Hunter. Bird stopped with chapter xiv., at which point it was taken up by his son Frederick Mayer Bird, and completed. It was published under the title $A$ Belated Revenge in Lippincott's Magazine, November, 1889 . 
copies sold and Bird's share of the profits, of his four chief romances.

R. M. Bird in acct. with

Carey \& Lea, Lea \& Blanchard.

\begin{tabular}{|c|c|c|c|c|c|}
\hline \multirow{2}{*}{\multicolumn{2}{|c|}{ Date of St }} & \multicolumn{2}{|c|}{ Calavar (pub. Oct., 1834) } & \multicolumn{2}{|c|}{ Infidel (pub. May, 1835) } \\
\hline & & No. sold & Bird's prof. & No. sold & Bird's prof. \\
\hline \multirow{9}{*}{$\begin{array}{l}\text { May } \\
\text { Nov. } \\
\text { May } \\
\text { Dec. } \\
\text { Jan. } \\
\text { March }\end{array}$} & $\begin{array}{r}7,1835 \\
12,1835\end{array}$ & $\begin{array}{r}1292 \\
303\end{array}$ & $\begin{array}{r}\$ 356.28 \\
\text { I6I.23 }\end{array}$ & $\ddot{I} \ddot{5} \dot{I}$ & $\$ 650.35$ \\
\hline & $\begin{array}{r}9, \mathbf{1} 836 \\
3 \mathbf{I}, \mathbf{1} 836 \\
\mathbf{I}, \mathbf{1} 838 \\
\mathbf{I} 8, \mathbf{1} 839\end{array}$ & $\begin{array}{l}\ldots \ldots \\
442 \\
234 \\
278\end{array}$ & $\begin{array}{r}174.43 \\
25.75 \\
60.16\end{array}$ & $\begin{array}{r}308 \\
80 \\
154\end{array}$ & $\begin{array}{r}\ldots . .4 \\
94.42 \\
14.40 \\
36.60\end{array}$ \\
\hline & & \multicolumn{2}{|c|}{$\begin{array}{c}\text { Hawks of Hawk Hollow } \\
\text { (pub. Sept., 1835) }\end{array}$} & \multicolumn{2}{|c|}{$\begin{array}{l}\text { Nick of the Woods } \\
\text { (pub. March, 1837) }\end{array}$} \\
\hline & & No. sold & Bird's prof. & No. sold & Bird's prof. \\
\hline & & . & $\cdots$ & $\ldots$ & $\cdots$ \\
\hline & & $\ddot{8} \ddot{6}$ & …… & $\cdots$ & $\cdots$ \\
\hline & & $\begin{array}{r}1000 \\
248\end{array}$ & $\begin{array}{r}\$ 779.03 \\
83.90\end{array}$ & $\cdots$ & $\cdots$ \\
\hline & & 130 & 26.13 & 2447 & $\$ 1150.37$ \\
\hline & & 183 & 43.40 & 281 & 144.27 \\
\hline
\end{tabular}

Bird's novels were also published in England by Bentley and others, in several cases with altered titles. Calavar was published in four volumes in I 835 by Newman \& Co., London, as Abdalla, the Moor, and the Spanish Knight. The Infidel appeared in a London edition of three volumes in 1835 as Cortes: or The Fall of Mexico. The Hawks of Hawk Hollow was similarly published in 1837 under its own name. London editions of Peter Pilgrim and of Robin Day, each in two volumes, appeared in 1839 and the most successful of his stories, abroad as at home, was Nick of the Woods, which first appeared in London in three volumes in 
1837, edited by W. H. Ainsworth. It ran through a number of editions and was translated into German,-Die Gefahren der Wildnis. Eine Erzählung für die reifere Jugend. Nach dem Englischen (Nick of the Wood) bearbeitet von Franz Hoffmann. Mit Bildern. Stuttgart, I847, $8^{\circ}$. From these foreign editions Dr. Bird, according to his wife, received nothing, except that unsubstantial phantom, reputation. ${ }^{x}$

See Appendix A. Three of Bird's novels were dramatized The Infidel was dramatized by Benjamin $\mathrm{H}$. Brewster and played in Philadelphia in 1835; The Hawks of Hawk Hollow was put on the stage in 1841; Nick of the Woods was dramatized by Louisa Medina in 1838 and proved one of the most successful melodramas of the time. 


\section{CHAPTER VI}

MARRIAGE, FARMING, TEACHING, AND POLITICS

IN order to treat together the novels of Dr. Bird, we have advanced our story to the year 1839 . In so doing we have run ahead somewhat of his personal narrative. To this we must now turn and record two events that were to be of largest consequence,-his marriage and his failing health.

In the copious assortment of letters for the year I 837 there is one of special interest. It is written by Dr. Bird to his favorite cousin, Dorcas Van Dyke, then Mrs. Charles Irénée Du Pont.

$$
\text { Phildada., July 9, } 1837 .
$$

MY DEAR Cousin,

I send you word by Mr. Du Pont that I should be extremely happy if your health and convenience would permit you to be present at a certain wedding about to take place, and engaged to give you early information of the day thereof. The day is now appointed,-Thursday next, at half past eleven in the morning, the ceremony to take place at church where I repeat it will give me great pleasure to see you. Although in church the wedding is to be entirely private, I inviting (besides mother and Miss Kitty who will be present of course) nobody but 
yourself and $\mathrm{Mr}$. Du Pont and also little cousin Mary, who is invited by her cousin that is to be. The ceremony over, I carry my bride home, where, after receiving a few of her friends, we shall have a family dinner to which I also invite you. I should ask you in addition to tàke up quarters with us; but I suppose we shall have to surrender all extra space for the honey-days to my new sisters.

Pray consider this news as confidential (the day and the place are both a secret) and believe me

\section{Your affectionate cousin}

ROBT. M. BIRD.

Mrs. Dorcas M. Du Pont

LOUVIERS

near Brandywine, Delaware.

It was thus that Bird announced his marriage, which took place on Thursday morning, July I3, I837. His bride was Miss Mary Mayer, daughter of the Rev. Philip F. Mayer, who performed the ceremony in his own church, old St. John's, Race Street, above Fifth, Philadelphia. Bird's acquaintance with the Mayers extended back to about I830, at which time begins a sequence of letters from Miss Mary and Miss Caroline Mayer, her sister, that possess a remarkable charm and interest. The Mayer family was one of great piety and refinement. Philip Mayer was one of Philas delphia's most venerable clergymen, and a pioneer of Lutheranism in America. He was the first American pastor to divest Lutheranism of its 
exclusively German character by conducting the service in English. For fifty-two years he sturdily preached the word to his only charge, old St. John's Church. He was also a man of widest interests and at various times served as President of the Philadelphia Dispensary, President of the Institution of the Deaf and Dumb, and a Trustee of the University of Pennsylvania.

After his marriage Dr. Bird made his home at No. I40 North Twelfth Street, Philadelphia, and with the enlargement of power that "love, home, ease, and happiness bring" gave himself to his pen most unremittingly. In March of 1837 he had completed Nick of the Woods. He had already written some of the tales for Peter Pilgrim, and was at work on others. In addition he now became engaged in what proved his largest magazine venture. For some time there had been talk of founding in America a periodical which should broadly and worthily represent the nation as a whole; hitherto no American magazine had quite succeeded in surmounting the strong sectional feeling that existed through the States, rooted partly in rivalry and partly in political differences. This feeling at times was of extreme bitterness. For an example, one need only recall, the relations between Poe, then editing the Southern Literary Messenger and the "Metropolitan littérateurs" represented by Knickerbocker's and The New York Mirror. The only periodicals that had anything like a nation-wide appeal were the British quar- 
terlies and monthlies, or those at home which derived a certain éclat from their foreign contributions. The result, as Charles Fenno Hoffman wrote to Bird, "was to denationalize our upper classes, all their thinking is done abroad." With two attempts to found such a magazine Bird was now concerned. The first was a plan of Thomas Cottrel Clarke. Clarke had recently sold his interest in The Saturday Courier on such terms as to place at his disposal "ample means and leisure"; and had outlined a magazine "on a more liberal plan than anything that has yet been attempted in Philadelphia." I The Courier, of which he remained an assistant editor, had a circulation of twenty-six thousand and through this he hoped to make the new venture known. Clarke invited Bird to undertake the editorial management of the new publication. In a letter of November I3, 1836, Bird defers a definitive answer to Clarke, wishing a fuller "understanding of each other's aims and expectations." In the meantime Charles Fenno Hoffman had drawn up a plan for a national magazine. He aimed primarily at the absorption of sectional rivalry by publishing simultaneously from Boston, New York, and Philadelphia The American Monthly Magazine, a journal that had already enlarged its scope by the absorption of three others, The American Monthly Review, The United States Magazine, and The New England Magazine. On January I I, I837, Hoffman offered

× Clarke to Bird, November 9, 1836. 
Bird the position of Philadelphia editor. His duties were to read and sift articles and to obtain or write reviews. $\mathrm{He}$ was to receive a yearly salary of $\$ 500$ and $\$ 2$ per page for work of his own. This offer Bird accepted and a prospectus dated February, 1837, announced him an associate editor of The American Monthly Magazine with Mr. Hoffman in New York and Mr. Park Benjamin in Boston. In May and June of 1837 he wrote for the new venture two articles on the Mammoth Cave; in August, "A Tale of a Snag," material for which, also, he had gathered in the Mississippi Valley on his Western trips. It seems he was planning, too, a new magazine of his own. Among his manuscripts I find detailed notes for The Adelphi, a literary monthly; a Philadelphia Weekly Gazette, a register of letters, arts, and news; and The New Whig Monthly. Furthermore, he was receiving requests from many editors, with some of which he complied. But on the whole he wrote comparatively little for the periodicals. The reason he thus plainly states in a letter to Dr. Samuel G. Howe, who had asked him to contribute to The New England Magazine.

"Neither my habits nor my inclinations as I will frankly confess have ever led me to write for periodicals; and the very few pieces of mine which have been printed were given, in all cases, at the request of personal friends. I am entirely of too discursive and diffuse a turn . . . to shine in a nutshell; and I have always felt 
more disposed to count by acts and chapters than by lines and paragraphs."

Those who have followed thus far the career of Dr. Bird must have early observed one fact,- the killing pace at which he worked. Between January, I834, and March, I837, he had produced four novels; furthermore, they were of an order to strike Nathaniel Parker Willis. with wonder "how he could afford to put so much material into a book," requiring exact portraiture and extensive research. Within this term also he had finished The Broker of Bogota, and had written with much other verse three complete cantos of The Cave, a descriptive poem of large dimensions. Besides, as we have noted, he contributed to magazines and assisted in editing The American Monthly. The mere labor of penmanship in such an amount of composition is only realized when one examines the reams of extant manuscript. But the cost of such an accomplishment was as sure as it was heavy; in 1833 and again in 1835 he had taken trips West to avert threatened breakdowns. With the enlarged opportunities that now came to him, his mode of life became correspondingly more sedentary and unhygienic. $\mathrm{He}$ ate, his wife relates, two meals a day, took little or no exercise; and, to escape the din and distraction of city streets, gradually fell into the habit of writing largely at night. The effects of such a régime

$\therefore$ Bird to Howe, letter undated. 
were inevitable, and his health began to show the signs of a serious collapse. As a result of impaired digestion he became nearly blind for weeks. In November of 1837 he was forced to sunder his relations with The American Monthly. $\mathrm{He}$ arranged and revised Peter Pilgrim at considerable disadvantage and wrote Robin Day under the pressure of actual suffering. Besides, there were worries from without. The publishing trade was disorganized throughout the country as a consequence of hard times. Bird was not alone to feel the pinch. Lea \& Blanchard writing to Poe shortly after regarding a second edition of the tales, was very desirous of being relieved of publication "at cost or even at a small abatement." Publishers everywhere preferred selling to buying. In June, I 838, Bird had a son born to him, Frederick Mayer Bird, bringing upon him its welcome but yet additional burden of obligations. ${ }^{x}$ With an overtaxed mind, failing sight, and a breaking body Dr. Bird at the solicitation of his friends and with a sense of responsibility to his family, decided to abandon literature and seek health in agriculture. From his letters it seems he thought of buying a

Frederick Mayer Bird (1838-1908) inherited many of the versatile talents of his father. Graduating at the University of Pennsylvania and Union Theological Seminary, New York, he held various pastorates and professorships until in $188 \mathrm{I}$ he became chaplain and professor of Psychology, Christian Evidence, and Rhetoric at Lehigh University. He was editor of Lippincott's Magazine, 1893-98, and of Chandler's Encyclopedia, 1898. He was also a widely known hymnologist and numismatist. 
farm in Maryland in January, 1837 . It was not until I839 that he bought one "in Bohemian Neck on the Eastern Shore of Maryland, situated on the Elk about seven miles below Elkton." Hither it was his intention to move in the spring of 1839 . $\mathrm{He}$ was prevented from doing so and in March, 1839, occupied a house in New Castle belonging to his brother, No. 4I I Delaware Street. Here, in the place of his birth, he rested for a year, indulging hobbies and amassing all sorts of agricultural lore. On March I3, I840, he occupied the farm.

Dr. Bird's life at Cabin Cove, or Bending Cove, or Bendico, or Bird's Nest, as he variously named his Maryland farm, is one of the most charming episodes in his career. Hither he retired, racked and jaded by the strain of city life, to the healing quiet of the countryside. Nor could he have chosen a lovelier spot. The farm itself with its three hundred acres of wooded uplands and shining water front was as rich in beauty as in soil. "Never was there a more beautiful river" he writes to his wife of the Elk. "It looks Susquehannaish. I wish you could have seen it yesterday in the glorious misty calm,-the piney headlands, blue hills, the dark and gleaming waters." Along its sandy banks he could hear the "fishermen singing their boat songs all day and all night." Three miles off was the steamboat landing and right before their door steamers could be seen passing each other at half past ten each morning. Their dwelling was a cabin, "old, ugly, inconven- 
ient, and shockingly out of repair" in Bird's own words, but rain-tight and "as good and rather better than most other houses in the manor." On a shady side of it he built a workshop, and installed a bench and tools. Here was labor for the hands of every kind and into it Bird threw himself body and soul. He rose at half past four in the morning and bent to his chores until half past eight at night. Asking pardon of his wife, as yet in New Castle, for not writing, he complains he had "to make fence, build pump, split palings, dig post holes, measure land, mark lumber, and the Lord knows what." The Elk, then as now, abounded in pike, perch, rock, and herring; and each season fishermen came with their pound-nets, traps, and tackle to fish for shares. Bird had always on the place "two good darkies"; but in the oats season fourteen hands came with their cradles. His neighbors were apparently primitive to a degree. "The people," he writes, "are all savages here, western like, live in cabins, without furniture; don't know the name or use of any chattel beyond bed, chair, and table; are amazed at a bureau, petrified at a pier-table, and come far and near to beg a look at your toilet."

Of his activities at Cabin Cove Dr. Bird has left records of first interest. No less than seven notebooks labelled "Agriculture" No. I, No. 2, and so on remain written with characteristic neatness and style, and illustrated with plans and diagrams. $\mathrm{He}$ interested himself in every phase of farming; 
devoured journals, read scientific treatises, and conducted experiments. He thought of improving hemp culture by cropping the same field each year instead of rotating, then the common practice. He compared the various methods of dressing it,pool rotting and steam rotting. He devised a new method of sulphuring manure to prevent undue fermentation; of extracting oil from opium by means of rollers instead of by incision; of cultivating sanguinaria used for dyeing purposes, but hitherto difficult to obtain in large enough quantities. He studied the production of madder, the virtues and uses of its roots; the relative merits of hedges, the evergreen, green brier, dogbrier, and privet. He tested a plan practiced in Bohemia of propagating apple trees. "The process is to take the shoots from the choicest sorts, insert them into potatoes, and plunge both into the ground, leaving but an inch or two of the shoot above the surface. The potato nourishes the shoot, while it pushes out roots." He investigated the production and possible uses of the pea vine, sesame, nettle, ground nuts, pink-root, acorns; and so on. He also applied his rare powers mechanically, and his notebooks are full of the most ingenious notions for new farming implements. He outlined a contrivance for removing stumps, a method of destroying the Hessian fly by swabbing the wheat with tobacco, hellebore, and aloes "by a watercart . . . having a flannel bag by way of a swab through which the fluid is slowly discharged." 
More ingenious than practicable is Dr. Bird's suggestion of a Pig Mill by which the whole sty is placed "on an inclined wheel haltering them to fixed troughs, in which a little food might be placed to start them. . . . The lazy beasts would perhaps be none the worse for a little exercise. A dozen of them would perhaps do the work of an ox." But the favorite scheme of Dr. Bird's was a method of making bricks. The materials were to be coal dust, turf, and clay wrought to the proper temper in large iron cylinders. By means of a mechanical cutting arrangement of large racks and drying-sheds with movable roofs the process was made much swifter and less laborious. Besides, Dr. Bird seems to have gathered a large fund of agricultural lore on many subjects,-banking and drainage, coal tar, marl beds, the nutritive value in different plants and roots for cattle feeding. These are by no means all of the varied and numerous plans and ideas that the new occupation struck form from Dr. Bird's teeming mind.

At Cabin Cove, Bird did little with the pen. It was his intention while there to write a history of the United States, for which he had gathered material many years. Lea \& Blanchard had stated a wish to publish it and now wrote Bird that they had "to keep the presses moving" and would be glad to have the book, mildly reproving him that he had not gone to work more resolutely. There was a slackened demand, it seems, for novels and the lighter forms. But history is not 
to be written in the fag ends of long work days. In a letter to his wife, April I5, I840, Bird declares, "History of the United States, indeed! If I wrote anything, it must be a history of my own bothers." In consequence he did hardly more on the book than to sift material and make notes.

It was at this time that the only attempt to stage Pelopidas, Bird's first prize tragedy, was made. The play had been accepted, it is to be remembered, by Edwin Forrest, though never performed nor paid for. Its literary merit had won the confidence of Dr. George McClellan and John Frost, who had interested William E. Burton. William E. Burton had recently sold to George R. Graham his celebrated Gentleman's Magazine and had built a new Philadelphia theater on Chestnut Street, where the Continental Hotel now stands. In April, 1840, Burton accepted certain terms proposed by Dr. McClellan regarding Pelopidas, and promised to bring out the play in the fall. At the time nothing more seems to have been done, although the play was not submitted. On September Ist Dr. McClellan again urges Dr. Bird to come to terms. Burton "wants to bring out the Pelopidas immediately. Scott has been faithful and made a stipulation with Burton to provide a [clearer] chance for Pelopidas. The offer is to put the play in immediate rehearsal and bring it out if possible on the I8th instant." On that date, it seems, Edwin Forrest was to bring out Conrad's Jack Cade at the old Chestnut Street House. 
With a chivalry that marked the man, Dr. Bird demurred out of pure deference to his friend, Judge Conrad. "I really think," McClellan writes on September I 7 th, "you are too delicate and scrupulous in your feelings about the bringing out of your play. Conrad would not have cared if his Conrad of Naples had sent The Gladiator to the devil, nor would he now care though his piece of radical rascality were to row poor Pelopidas up salt river." A last attempt to have the play staged was made by John Frost, to whom Burton then wrote:

J. Frost, Esqr.

MY DEAR SiR,

I will produce Pelopidas with all possible splendor and befitting appointments. I will share with the author the proceeds of the house, nightly, the same as with a principal star, deducting the expenses, averaging $\$ 250$, with a third of the gross proceeds of the seventh night, clear of all deductions, for the author's profit, reserving to myself the sole use of the tragedy in the City of Philadelphia, so long as I remain manager, but making no claim for its use in any other city, the profits of said use in other cities to be at the author's own disposal.

I believe that the production of Pelopidas will answer the purposes of all concerned. I pledge myself that it shall be produced in a superior way, and that the character shall be well supported.

\section{I am, my dear Sir,} Your obedt Servt

Nat. Theatre, Phila.,

W. E. Burton.

Dec. I 5, I840. 
P. S. Should Dr. Bird prefer, I will give him ten per cent on the gross receipts nightly whenever the Tragedy is played.

There can be little question of the success of Pelopidas had it been given. Burton had taken fortune by the forelock. He was well backed; his new house was thronged daily; he had engaged one of the best stock companies to be had in the States. He had won the people's confidence; and they were ready "to puff everything produced," as McClellan wrote Bird, "to the height and depth of its merits." Furthermore, he expressed a wish to have all that Bird could write for him and would "push them all" in other cities. What it was that induced Dr. Bird to hold back his play is not plain. It may have been in part at least a dislike to engage in rivalry with Conrad; or possibly an absorption in other matters; or a distaste for a phase of literature that years before had wrought him such injustice. The fact only remains he did not submit Pelopidas.

But if labor with the pen at Cabin Cove yielded little, the work of his hands, the fresh air, and the quiet life on a farm soon brought health and invigoration. "I am as hearty," he writes to his wife, September 22, I840, "as if I never had ailed." His sight mended; his face acquired, we are told, the florid tints of "an Englishman." In a word, his term of life was unquestionably prolonged by the change. But a productive farm of three hun- 
dred acres entails other considerations. Rich as was the soil, there was an instant need for large improvement, all of which was heavily expensive. The year's crops had been what the farmers call "a failure." Besides, the prospect of spending the winter with a wife and child in hardly more than a cabin was far from attractive. Consequently on September 25, I840, Dr. Bird thinks of moving to New Castle "more sorry to leave the farm than I can express. I cannot look around me but my eyes fill. Here we could and might have been so happy, had my beggarly fate been a little more propitious. The season of health and delight has just begun. . . . All is peace and beauty. . . . Yes, the beauty of Bendico is just beginning." Shortly after he moved his family to the house in New Castle, No. 4I I Delaware Street. It is from this time that our only first-hand impression of Dr. Bird dates. Miss Emily Rodney, of the wellknown Delaware family, once a playmate of Bird's son, remembers the dramatist, a tall, large, impressive figure, clad in a cloak, with spectacles, a characteristic erectness of head, and a stride of unusual energy in his walks about New Castle. $^{2}$

In the spring of I 84I Dr. Bird turned to a profession for which he was superbly fitted, but which

I Bird to Mrs. Bird, September 25, 1840.

'I am indebted for this account of Dr. Bird to Mr. Henry Hanby Hay of New Castle, a brother-in-law of Miss Emily Rodney. 
to him was always the most irksome of tasks,teaching. In the fall of I839 a new medical college had been founded in Philadelphia, located on Filbert Street above Eleventh and known as the Pennsylvania Medical College. In origin it was a branch of the Pennsylvania College at Gettysburg. By a special act of the Legislature in 1839-40 it was empowered to grant degrees in the city of Philadelphia and given privileges equal with other medical schools of the State, the Faculty thus becoming virtually a board of trustees. Upon it were eminent physicians and warm personal friends of Dr. Bird,-Drs. William Rush, George McClellan, Samuel G. Morton, and Walter R. Johnson, his old teacher at Germantown Academy. The College numbered a student body of some 250 men. At this institution Bird was offered the professorship of the Institute of Medicine and Materia Medica, made vacant by the death of Dr. Calhoun, which he accepted in May, 184I. Leaving his family in New Castle, he went to Philadelphia and took lodgings at No. 20 Montgomery Square, Race Street above Tenth, and later at No. 28 North Eighth Street.

Among Bird's extant papers are his lectures in Materia Medica with two printed addresses. They are written with all the ease of phrase, the wealth of allusion and anecdote that only a man of his literary gifts could command. Reading alone suffices to disclose their grace of form and interest. For such a one teaching would supposedly have 
been a delight; the opposite, however, seems emphatically to have been the case. Of course, the circumstances were in part accountable. On December I2, I84I, he writes to his wife, "I am kept too mulishly busy to enjoy care. The class is very small, under eighty, I believe. There was a ridiculous mistake about its being near one hundred. Of course I shall make very little money; and of course also I am disheartened. Nevertheless, my colleagues are in such good spirits that they talk of building a new college, having sundry tempting offers there anent. I don't know what I shall do; I have not time yet to make up my opinion. My feeling is to retire in the spring; but I have till the spring and some time after to think about it. I certainly do unutterably detest this living and drudging a whole winter in separation, and all for nothing. The work expended on my lectures would have written my Hist. of U. S.; but I don't know, indeed, that the history would have paid me any better, these hard times. Oh, for a little ease, and quiet, and laziness." The second year was not more pleasant. On July II, I842, he writes, "The two months crept away very slowly, and instead of rejoicing that a week of the term is passed away, I grumble because it is not two or three. However, Sunday will bring us to the middle of the month and then there will remain but six weeks more bother or at least of lecturing." Notwithstanding Dr. Bird gave two full courses of lectures in $1841-42$ and $1842-43$, 
continuing in connection until the disorganization of the institution in 1844 .

During his residence at New Castle, also, Dr. Bird formed one of the most fruitful friendships of his life, giving to his interests still a fresh turn. In the spring of 1842 John Middleton Clayton occupied the old mansion known as the Read House on Water Street, New Castle. Clayton had already begun his career of distinction. He had been a senator at thirty-three, had served a distinguished term on the bench, and was already counted one of Delaware's leading statesmen. In politics he was a strong Whig, as the new reforming party was named that came into existence about I837. Through Dr. McClellan, John M. Clayton and Dr. Bird met and formed an intimacy that lasted throughout their lives. Through Clayton, Bird, too, became an active member of the Whig party; its principles of reform he had long stood for, its leaders he now came to know and to admire. Accordingly in the spring of 1842 , when a Congressional vacancy occurred through a declination of a renomination by Mr. Rodney, Dr. Bird was pressed to run. He reluctantly consented and took the stump in his own behalf. In his extant speeches he sets forth two claims for consideration. "I am a FULL BLOODED DELAWAREAN and I can boast ... that five or six generations of my fathers were born upon and now molder beneath the soil; and then I am a Whig, a very good one." But from the first he was uncertain of his wish to 
enter politics. It was, he declared, like Malvolio's honor "thrust upon him," and he would go from a sense of duty. "The thing perplexes me, you may be sure," he writes June 12, 1842. The state of the medical college was dubious. And yet his wife opposed on all grounds the Congressional nomination. It would mean separation from his family; a permanent appointment in Washington might ensue; but "to be among that scandalous set that disgrace the House" was her prime objection. Besides, a new professorship had been heard of in Lexington, Kentucky. The nomination was to be July 5th. As late as June 29th Mr. Rodney's declination was uncertain. Out of deference to his wife's wishes, and cooled by the delay and the uncertainty, Bird withdrew from the running.

For a brief term he again turned to literature. He revised his four dramas,-Pelopidas, The Gladiator, Oralloossa, and The Broker of Bogota. He gathered sources for a history of the annexation of Texas and the Mexican War, of which he wrote one chapter, still with his manuscripts. $\mathrm{He}$ wrote the portion of a novel entitled The Celebrated Mrs. Munchary, a satire on the new woman of the day. ${ }^{x} \mathrm{He}$ drew up a plan for the

I It is written in a series of letters and can perhaps be best described by Bird's own description of a vignette illustration to accompany it entitled "Young America": "Foreground-Street. A man nursing the baby, while his wife knocks down a lady for insulting him; a horsewoman astraddle, gallanting a gentleman on a side saddle; twogirls fighting, and all the boys screaming for fear. Background. An Open Senate Chamber. Two wenches keeping 
organization of the Smithsonian Institute. $\mathrm{He}$ further wrote a part of a memoir of John M. Clayton, and a sketch of the Life of Major Thomas Stockton, which was printed and widely read. In it he cleared Stockton of vicious charges fabricated by political opponents, and greatly aided his election as Governor of Delaware.

One more service for the Whig cause during Bird's life at New Castle remains unchronicled. This party, it seems, had soon gained an astonishing strength and influence; about its standards were gathering some of the ablest men in the States. A great Whig Convention was planned to meet at Baltimore to organize and nominate for the coming election. Henry Clay was slated for the Presidency. Among the candidates for the Vice-Presidency was John M. Clayton. In behalf of his friend Dr. Bird once more took the stump. Speech after speech he made to the various Clay clubs in the Hundreds and cities, vigorously asserting the claims of the Whigs, lauding their leaders, and denouncing the Locofocos. "I believe the man never yet lived," runs one of his speeches, "who had a more noble spirit, a truer love of his country, or a greater capacity to render it great and prosperous than that nature's gentleman ... whom the American people now mean to make their President,-Henry Clay of Kentucky. And if there is anyone else in the land who equals or

the door, and a female Senate, harangued by a female Demosthenes, who gesticulates at the expense of her petticoat." 
approaches him . . . that is John M. Clayton of Delaware." To the great Whig Convention at Baltimore in May, I844, he went as Clayton's personal representative and received the statesman's friends as they arrived from different quarters of the Union. This Convention he describes in the following letter to his six-year-old son, writing legibly and naively warning him of the dangers of life in Philadelphia. As it closes Bird's political activities, so it may suitably close this chapter.

\section{MY DEAR LITTLE SON,}

I arrived from Baltimore in safety, along with my trunk, which I had the good fortune to recover. Everybody who travels should look to his own luggage, and then he will not lose it.

I had a very agreeable time at Baltimore, seeing and hearing things, which you would have been delighted to see and hear. There were thousands of men walking in a vast procession, with beautiful banners and bands of music; and all persons had splendid badges and medals, such as I have given your dear mother to send up to you. All this was in honor of Henry Clay. But I shall tell you more about it some other time.

I hope you are well and that you enjoy yourself up in Philadelphia. I learn from the newspapers that there are wicked men up there, who are fighting and shooting, and killing one another. It is a very bad business; and I desire that you will keep out of their way: for, though I do not apprehend you would shoot anybody, yet somebody might shoot you. 
When you are tired of Philadelphia, I shall be rejoiced-and so will your dear mother be-to have you back again in New Castle.

I hope your grandpa has got well. Give my love to all your aunts, and believe me

Your affectionate father, ROBERT M. BIRD.

Frederick MAYer Bird.

9 


\section{CHAPTER VII}

\section{JOURNALISM}

IN one department of his career Robert Montgomery Bird was supremely happy; in his home life he was blessed beyond the lot of most men. To that he could always turn and find "peace and trust and affection." His was one of those strong, chivalrous natures capable of inspiring in women a regard that literally amounted to devotion. During his life it was the first concern of Mrs. Bird to make their home a place of inviolate sanctity and peace, and to soothe and cheer a nature that perhaps was ever too sensitive. After his death, not content with leaving a detailed memoir of his life, she diligently gathered and preserved every bit of paper his pen had touched. Furthermore, his was a life of few strifes and many abiding friendships. One misses an essential trait of the man who omits to mention his uncommon power to inspire strong attachments. To this fact the obituaries following his death without exception bore witness. As the list of these intimacies is long, only a few can be given here. They deserve mention because, more than others, they shaped 
his development. There was Dr. George McClellan, the well-known physician, through whom Dr. Bird met Edwin Forrest and who until his death was tireless in Bird's behalf; John Frost, the historian, ever the best of friends; James Lawson, whose bounty went forth to many a struggling author; W. Gaylord Clark, through whom Bird met Longfellow; Hiram Powers, the sculptor, whom Bird-among the first to perceive his giftsstarted on his career encouraged. Though a friend of his later years only, none stood closer in Dr. Bird's regard than John Middleton Clayton, Delaware's great statesman, and Secretary of State under Taylor. Their friendship, it seems, was mutual. "I love you," wrote Clayton to Bird, August, I848, "better than any man on earth except my own children and while my heart shall pulsate that feeling will never abate." At his friend's death, Clayton left, besides a codicil in his will designed to ease the weight of debt on Mrs. Bird, a bequest of five hundred dollars for the erection of a monument to Bird's memory, provided he be buried in his native State.

After the Whig Convention at Baltimore in the spring of I844 Dr. Bird retired to New Castle where for about two years he again pursued favorite schemes. Chief among these were experiments in industrial chemistry. He was.perfecting a method, his wife states, for "the manufacture of niter, saltpeter, and magnesia, and his experiments in the preparation of a superior form of that article 
at a cheap price had resulted in complete success. He was delayed in the establishment of works for this purpose by the difficulty of procuring a suitable lot and buildings." His friends, too, were urgent in his behalf. In April of 1844, John Frost, then a sub-editor of Godey's Magazine, solicited him to become a regular contributor and suggested a series of sketches based on Mexican and Peruvian history. Through the death of Professor Sanderson the chair of Classical Literature in the Philadelphia High School was made vacant, and its acceptance Frost was pressing on Bird. Of course, it paid only $\$ 1100$; but the duties were light; his afternoons would be free to devote to writing; and the book trade was now in full blast. Along with it he might also hold his professorship in Materia Medica. In March of 1846 Clayton urged him to accept a Prothonotaryship; stating "that it will be offered you." The same month his father-in-law, the Rev. Philip Mayer, writes, "Mr. Lea is very desirous you should prepare the long talked of history of America or the United States (I don't know which). Mac[Clellan] added that Lea intimated a disposition to pay Four Thousand Dollars for it in instalments as the work should come out." In April, I846, Dr. Bird was appointed by Governor Maull a director of the Farmer's Bank at New Castle. On December 7, 1846, he wrote for The North American an article on the Smithsonian Institute that awakened wide attention. The Board of Regents had just ap- 
pointed to the Secretaryship Professor Joseph Henry, of the College of New Jersey at Princeton. This appointment Bird warmly commends and takes occasion to outline the uses to which, he thinks, the bequest should be put. It would be unwise, he urged, to found another college; of these there was already plenty. On the other hand America had no institution like the Royal Society of London or the National Institute of France, with its sole end the promotion of science. To this purpose the Smithsonian bequest with the nation as its guardian might well be put. The subsequent development of the institute on almost exactly the lines Dr. Bird suggested has proved the wisdom of his views. At the time the article drew attention to Bird's fitness for a position in the institution. From a letter of Clayton's, January 22, 1847, it seems Professor Henry wanted him as an associate; that his appointment had been moved; and that Henry was to be "the scientific man" and Bird "the literary man" of the institution. This plan, . however, came to naught through Dr. Bird's purchase of a share in The North American (newspaper) and his removal to Philadelphia. At the solicitation of John M. Clayton, through whose loan the purchase was made possible, he bought on June 23, I847, of George R. Graham and Morton McMichael "one third the joint establishment of The North American and United States Gazette including all the properties appertaining to the establishment to the amount for one third 


\section{LIFE OF ROBERT MONTGOMERY BIRD}

as above stated" for $\$ 30,800$. Since with this publication he was connected for the rest of his life, and in itself it is a notable journal, a brief review is in place.

The North American, according to Frederic Hudson, "can claim to be, by purchase, the oldest daily paper, morning and evening, published in the United States." Like many publications of its time it had a very composite development and had absorbed wholly or partly no less than ten periodicals. ${ }^{1}$ Under the name of The North American it was first issued, March 26, I839, at No. 63 (now 233) Dock Street, Philadelphia. In October, I 845 , it was sold to George R. Graham and Alexander Cummings, who engaged Robert $T$. Conrad, the distinguished jurist, poet, dramatist, and orator, as editor. A difference of political views, however, led to a dissolution of the firm, Mr. Graham remaining sole proprietor until January I, I847, when Morton McMichael became associated with him in the firm of Graham \& McMichael. The paper at this time was an eight-column folio, with a head similar to that now used and with the motto "Devoted to Truth." It was published at the northwest corner of Chestnut and Fourth Streets

I Ist. The Pennsylvanica Packet or the General Advertiser, 1771. 2d. The American Daily Advertiser, 1784. 3d. Gazette of the United States, 1789. 4th. Evening Advertiser, 1793. 5th. United States Gazette, 1804. 6th. True American, 1820. 7th. Commercial Chronicle, 1820. 8th. The Union, 1820. 9th. The North American, 1839. 10th. Commercial Herald. (Hudson, History of Journalism, p. 183.) 
until its removal in July, I848, to No. I32 South Third Street. At the beginning of 1847 The North American and The United States Gazette were separate, though of like aims and standing. Both were of Whig persuasion; both advocated protection; both gave loyal support to city and State interests; and both were highly successful, though naturally competitors. On July I, I 847 , when Dr. Bird became associated, the two papers were joined in one of nearly the present size. "It is not often," runs the editorial in that issue, "that such union is effected-they believe, indeed, that such union has never before been effected in the United States-between two journals in such a completely flourishing condition as The United States Gazette and The North American, the one possessing all the solid and long established business relations which are the fruits of mature age, the other the vigor, and energy, and rich promise that belong to active youth." The announcement of its editorial force includes, Robert T. Conrad, in charge of the political department; James S. Wallace, general associate editor, G. G. Foster, city editor; and Dr. Robert M. Bird "whose high attainments in literature and science are universally known and appreciated," who was to preside over the miscellaneous department. The firm, known as Graham \& McMichael, was located at No. 66 South Third Street, Philadelphia. ${ }^{\text {I }}$

I Among the Bird MSS. I find the following testimonial regarding The North American from Henry Clay: 
Removing to Philadelphia Dr. Bird assumed his new duties with ardor. His editorials, written in neat and melodious phrase on a wide range of subject-matter, are not hard to identify and shall be briefly treated in their place. Here we are only concerned with the outer aspects of the undertaking. The burdensome tasks that rest on the editing force of a daily newspaper are too well known to need mention. In Bird's case, it seems, they were unusually heavy by reason of an utterly unbusinesslike management with no equal division of labor whatever. Judge Conrad-lawyer, dramatist, poet, journalist-had so many interests that he was able only occasionally to contribute to the columns. George R. Graham was hardly more helpful on account of his frequent "frolics up the river" as Bird put it, and his load of copper speculations. Morton McMichael was engaged with the business management. In consequence the burden of editing lay upon Dr. Bird. Already in December of 1847 the constant confinement throughout the

"I have received and attentively perused many months the N. American published in Philadelphia, with which the $U$. States Gazette is now associated; and I take pleasure in bearing my humble testimony to the consummate ability with which it is generally edited, and to the soundness of the principles which it labors to illustrate and establish. I think it eminently merits public patronage, and especially Whig support. If that great cause should be triumphant, as there is now ground for confident hopes, that paper must be regarded as one of its most fearless champions and enlightened supporters.

"H. Clay."

"Aug. 1847." 
day and half the night had again brought the warnings of a serious disease. Before the year was up, he was plainly overworked and desponderit. "The experience of a year," runs a jotting in his hand dated June 19,1848 , "satisfies me that the concern cannot be safe and prosperous as it ought to be without the entire devotion of all the proprietors' time and functions to all its interests, and a systematic regulation of functions such as will produce some equitable divisions of labors." Besides, the policy of the paper had at times taken a turn offensive to both Bird and Clayton. It had engaged in ill-advised personal assaults that had stirred violent complaint. In May, I848, Clayton writes Bird, "I have no confidence that it will ever regain the good opinion of the men it has now attacked"; and advises him to end his connection at once and come to the Delaware Farm. "Green fields and bullocks are better objects of contemplation."

The chief source, however, of Bird's uneasiness was the copper speculations of George R. Graham. Graham it seems was in one of those periods of recklessness and dissipation frequently marring a career that might have reached distinction. In I 848 he was forced to transfer the magazine that had so long and famously borne his name to Samuel Dewees Patterson, "a series of misfortunes" to use his own phrase "having bereft me of any proprietory interest in this magazine." He was retained, however, by the new owner as one 
of the editors. Through his plunging, it seems, he was also undermining The North American. In a letter, June 22, 1848 , Bird sets forth to him the result of his conduct. "The credit of the firm is impaired, its solvency publicly doubted, its character seriously injured, and its influence greatly lessened." $\mathrm{He}$ pleads with Graham to relieve himself of his "load of speculation and return to real business." On July 7,1848 , there is a further rebuke for using the name of the firm for private business. "Since July Ist, . . . I find that you have used the name of the firm-as on checks and drafts-without consultation of either McM [McMichael] or myself for your own private purposes." On July I0, I848: "I discovered today almost by accident that the checks of 'Graham \& McMichael' have for some time past been sold to Brokers and that while I have been taught to regard the raising of $\$ 1000$ as a peculiar privilege, discounts have been obtained on the credit of the firm for $\$ 32,000$." Little wonder it is that Dr. Bird, with whom honor was instinctive and final, writes, August 23, I848, to his wife, at that time in New Castle and somewhat tired of its drab dullness. "I also feel sorry at your giving so bad an account of New Castle, which with all its faults, I prefer to all the Philadelphias that are, were, or will be, and would be glad to accept in exchange with $\$ \mathbf{5} 500$ a year independent income giving a receipt in full for all claims upon fortune and the pleasures of Philadelphia. I know the vices of the people; but there 
is no dream among them of the settled rascalities of a city."

Elsewhere among Bird's memoranda is the following summary of the situation.

"I. The first year: the circumstances and the result.

"A. The circumstances. I have devoted myself to the $N$. $A$. to the entire exclusion of the private business and personal interests. I have had distinct offers for literary work which I could have performed within the year, employing half my time in it, amounting to $\$ 2500$; with various contingent offers: so that I might easily have made arrangements for private business requiring four or five hours a day which would have brought me the interest of the bond-a very tempting opportunity. Declined all, however, to give all time to the paper in the hope that this sacrifice would ultimately be compensated by increased character, business, and profits. The circumstances of the last three or four months have been unfavorable to my hopes and to all prospects of increased business, character, and profits; and as the second year approaches presenting to me a spectacle of doubt and gloom.

"The question is what inducement have I to continue longer, under my particular circumstances laboring as it seems in vain under a load of difficulty and anxiety, which no efforts or sacrifice of mind, unaided by a common effort and sacrifice of all, can make available?

"B. The result. The anxieties of the last three months have prevented my keeping the run of accts. I have not had time enough or tranquillity enough scarcely to do my writing. 
If the result be at the end of the first year, to leave me with an increased instead of diminished burden, it is clear that I cannot go on at such a rate. . . . I am extremely desirous of knowing the real condition of things, before the year is out that I may do whatever is necessary and practicable under the circumstances before a 2nd year begins." I

A rearrangement at last was imperative and an indenture dated July, I848, announces Graham's withdrawal from the firm; and another in August, a reorganization under the name of McMichael \& Bird. Graham's share was halved and bought by Elijah Van Syckel and Thomas McElrath. The stipulations of the indenture seem expressly designed to prevent another situation like that just concluded, and call for an equal division of labor and books of accounts kept at the place of business wherein "true and perfect entries shall be made of the receipts and expenditures."

To summarize Dr. Bird's views on the many questions of the day, as expressed in his editorials, would be both difficult and needless. We find what might be expected of a loyal American of Whig principles and broad literary culture. If any events of the day more than others made him feel sharply and write strongly they were, first of all, our relations with England. Ever since his own

II have slightly altered the original document, which reads:

... A. The circumstances.... 2. The result. 
early humiliation at the hands of Bulwer and the English bookmen, his attitude toward England was one of stout independence. He sharply. resented England's condescension towards America as to an upstart nation. Our swift advance in culture as well as in the industrial arts she was forced to admit. Yet she always fell back with galling complacency upon her age as a point of unattainable superiority. Her self-righteousness never ceased to fire him, and yet he questioned her political good faith. How could she chide us as she did for our aggression in Cuba in the face of her own in Asiatic Burmah? How could she propose a Tri-Partite Treaty between France, United States, and herself regarding Cuba when only three years before she had agreed to a similar arrangement touching Central America and was at that moment violating it? Again the affairs of Mexico were with Dr. Bird a frequent theme. Then as now Mexico was writhing in the throes of war and insurrection. President Arista had resigned his authority in despair; there was no such thing as patriotism in the country; no aptitude for selfgovernment. Would she become the prey of England, France or Spain? Toward Mexico Bird's attitude was always sympathetic; he realized her great resources; and pitied her degradation. Again, John M. Clayton and the famous treaty that bore his name were frequent themes. In I $85 \mathbf{I}$, it is to be recalled, the treaty was invidiously attacked and the whole of Taylor's administration 
involved. In behalf of Clayton and his treaty, Bird wrote one telling appeal after another, zealously vindicating the wisdom and character of his friend. Finally, running through Bird's editorials is a strong and intelligent advocacy of local affairs, of home trade, of home arts and institutions. Dr. Bird would have subscribed warmly to what has been termed "the higher provincialism."

The style of these editorials can be best brought to the reader, perhaps, through quotation. The following paragraph is taken from an editorial of January I, 1850, entitled The New Year. Its quaint eloquence, its mellowness, and its tone of sadness-possibly a reflection from Bird's' own life at the time-are characteristic as are also its perfect ease and fluency.

"At this season the mind naturally reverts to the past and recalls whatever of good or evil has marked the year that is gone. The instinct is a happy one by which we are led to pause, as it were, at certain stages of life's journey, and to look back with a reflective eye to the scenes and incidents encountered on the way. It is customary to regard the advent of each year as an occasion for social enjoyment; and accordingly men observe it as a season of festivity. To the young, who are looking forward to what lies before them, and who have little business with memory, it is a pleasant time, and as they enter each year, Hope, like an angel, waits upon the threshhold and promises to lead through a fairy 
world. They go right willingly and turn no regretful look behind. But to many the hour brings little pleasure save in the reflection of the happiness of others and the recollection of earlier and light hearted years. There is a spirit in the time that takes us gently by the hand and leads us back over the once shining track of our young days, and points to many a hope, and joy, and fair promise that have perished like the blooms of Spring, hopes and joys that we know we shall find no more, upon all the Earth forever. For the seasons may renew "the lilies of the valley," but they can never bring back to our hearts the blisses and affections of youth. At times like this, we may from the lifeless leaves catch some faint hint of the once surpassing sweetness of the flower, but all that is left us besides, is regretful retrospection. For many of us, therefore, the hour has something of melancholy. Yet he who in a spirit of self-examination reviews the past may gather from its lessons a wholesome philosophy, which must make him both wiser and happier in the future. Let us all then, today, make up our account with the year that has closed, and so listen to its admonitions that we may turn to our improvement the discipline of experience. In this manner we may extract blessings even from misfortune, and learn how "sweet" indeed "are the uses of adversity." 


\section{CHAPTER VIII}

\section{LAST DAYS}

IT seemed inevitable that Dr. Bird's facile powers and a spendthrift willingness to place them at the use of others should sooner or later make him the victim of drudgery. He did tasks with an ease that belied their magnitude and invited further imposition. "I do, I may say," he writes to Clayton, "all the writing of the paper (the Judge has scarcely furnished three articles in three months) and my whole time from 8 A.M. to I next A.M. every day is laboriously occupied in my duties; and relaxation or pleasure of any kind are things I never know." One wonders why a man who assuredly knew the risks he ran of serious damage to his health should have shown so total a disregard. Any answer must be of course conjectural, but one reason, it seems, was the financial obligations the business had laid upon him. To meet the interest of a loan Clayton had generously made, seemed a point of honor that caused him the deepest anxiety, so-concerned was he lest their friendship should incur a strain. To this obligation and the absolute necessity of meeting it he 
refers again and again in his jottings. And then, of course, Dr. Bird was of the type of man, whose energies grew with the demand upon them. Hard work rather stirred fresh effort than discouraged him. Only the premonitions of a breakdown led him to slacken his pace and take occasional diversions mostly in the shape of short visits to Buena Vista, Clayton's farm in Delaware. From here he writes to his wife, April, I852: "It is so agreeable and yet so tiresome to feed the chickens, and look at distant prospects which I can't see without eyeglasses or spy glasses." Again in July: "I am the more pleased to see Fred this afternoon as it gives me the opportunity of sending you word that I am doing extremely well and am decidedly improving by the air, exercise and eggs of Buena Vista. Mr. C. is very kind and wishes me to stay all summer." Again in September: "I received, th s afternoon, a letter from $\mathrm{Mr}$. Clayton requesting me in so urgent a manner to go down to see him on some business which he represents as of great importance to him that I do not see how I can well avoid it; and I think it not improbable, therefore, that I shall run down on Saturday to return, I hope, on Monday." From his letters it is clear these visits were fairly frequent.

Although Dr. Bird's interest in the works of his pen had greatly flagged, he did make occasional efforts to copyright his plays and to revise his novels. In January, I85I, he had consulted Clayton about the legality of Forrest's possession of his 
dramas. But nothing, it seems, could be done. "It would be a difficult thing," Clayton writes, "to give any correct opinion about the effect of your contract with $\mathrm{E}$. Forrest, because if I understand you, you have no written contract and your only witness, poor McClellan, is dead. You have suffered him to take copies of your tragedies. What have you in writing, or what evidence have you by letter or otherwise? If you sold him a right in your plays, what proof have you that it was not an absolute and unlimited right? It appears to me that if you have suffered him to take copies of the plays and act them, you will have a great deal of trouble to get anything out of him, no matter what he does with them, unless you can prove that the right sold to him was a mere right in him to act them, and not transferrable to others. The length of time he has had them tends to strengthen his claim. The copyright ought to be secured to yourself." $\mathrm{He}$ was also planning a new edition

${ }^{x}$ Forrest's views in the matter may be gathered from the following letter written years later to Dr. Bird's son, who was planning to publish the plays.

“ Mr. FREDERIC M. Bird,

"Philadelphia, October I, 1869.

"DEAR Sir,

"The heirs of the late Dr. R. M. Bird have neither right, title, nor any legal interest whatever in the plays written by him for me, viz.: The Gladiator, The Broker of Bogota, and the play of Oralloossa.

"These plays are my exclusive property by the right of purchase, and for many years by the law of copyright.

"Yours respectfully,

"EDWIN FORREST." 
of his romances and in the spring was at work on Nick of the Woods. Pressure of business, however, prevented its completion, and in November, I852, he was still negotiating with Mr. Redfield, when "ill health and the peremptory commands of my medical friends" forced him to go West. ${ }^{\mathrm{x}}$

In January, I853, George H. Boker consulted Dr. Bird regarding a Dramatic Authors' Bill, which he was endeavoring to have Congress pass. As the subject is of interest in itself, and the letter is Bird's last recorded utterance regarding the dramatist's profession, summarizing his own early experience, it is given in full. The last paragraph is of especial autobiographical interest.

Philadelphia, Jan. 31, I 853 .

MY DEAR MR. BOKER:

If I might advise you as to a Dramatic Authors' Bill, I should say by all means go to Washington, and endeavor to enlist the feelings of a few leading members of the House in its favor. The weakness of the bill-or of the Cause it represents (which is also or ought to be, its strength)-is that nobody cares anything about it one way or the other,- - except yourself, the four or five dramatic writers who, like you, have courage still to labor in a service surrounded by so many discouragements, and myself, who

' Referring to his business worries at this time, Dr. Bird says: "I should not let these things trouble me so much, if they did not interfere with my writing; to do which one ought to have a composed and quiet mind. The brain-machine is as delicate as a chronometer; it takes but a little shake to put it out of order." 
have reason to remember, from the experience of former years, the injurious workings of the existing system. The dramatic interest is-and as long as the acting right in a play is not recognized by law will remain - so utterly insignificant that members of Congress cannot be expected to trouble themselves, or even think about the bill, to ask what it means and what object it is to subserve unless some one like yourself, who might claim the kindly personal consideration due to the gentleman and literary man should devote a few days to the duty of explanation and advocacy. Nobody knows or cares anything about the measure; but on the other hand, nobody that I know of makes any objection to it. There is absolutely no opposing interest. Neither managers nor actors have any interest against it; nor have publishers or readers. To every person except the dramatic writer alone, it makes no difference whether the law passes or fails. Some advantage would result from it to all. The theaters would have more new plays to produce - the publishers more copy to print - the public more books to read. The immediate advantage to writers would be not unimportant to them pecuniarily-though no one would be taxed in consequence; while the great benefit would result in the power the author would have of publication without thereby divesting himself of his property-the only property of any real value in a play, as you so well know, lying in the right of representation. The want of recognition in the copyright act of the right of representation compels authors to keep their plays in manuscript, and confine their use to a single act or manager. The market is shut up-, the field of literary adventure is 
barred; the writer's only means of communication with the world is through the rantings and blunderings of illiterate companies. No wonder so few American poets are willing to try their fortune on the stage where the risk is great and the condition of Success is the surrender of every aspiration for literary fame. Had there been a Dramatic Authors' Law in Shakespeare's day, we should have had his plays revised and corrected by himself and published during his life. He made his money by acting them, and could not afford, by publication, to surrender the privilege to rival theaters.

When it is remembered that all the European governments have by law recognized the authors' right of representation in compositions designed for representation; that the bill now before the House is adverse to no interest and is opposed by no person, out of the House-that it cannot possibly do any harm or wrong to any human being-that it may have as it is likely to have, a good effect in stimulating the efforts of men of genius in the United States in the drama,-a branch of literature more neglected among us than any other,-and that those members who may take a leading part in procuring its passage are very likely to be remembered with gratitude by those whose gratitude is sometimes immortality it is hardly to be supposed-at least I cannot suppose - the bill will meet any opposition, should the Committee being in charge report favorably, and one or two members say a good word in its behalf. If it goes to the Senate, I feel satisfied it will not meet with any difficulty there.

I have not thought it necessary in writing you this note to say anything about my personal 
experience-now almost an old world recollection-of matters bearing on the question you have at heart. I do not think, however, that my experience would be found to differ from yours. I do not know that this bill if it became a law would ever be of any benefit to me; but I am very sure, if there had been such a law in existence twenty years ago, I should not have abandoned dramatic writing, as I did, in what was the moment of Success and the period of youthful vigor and enthusiasm. I have enough of the old leaven to feel a sympathy in the cause - (eleven or twelve years ago as I once mentioned to you I endeavored having an attack of the old ardor Scribendi) to get such a bill introduced into Congress, but, it being near the close of the session, I laid it over for next year, by which time, my attention was absorbed by other matters; and, while doubting whether I shall ever again feel any ambition to delight the groundlings, I am desirous that you and others who will rise around you may escape the evils of the discouraging system under which I suffered. . . . . .

George H. Boker.

ROBT. BIRD.

The spring and summer of 1853 again brought their return of ill health. In March, in July, in October, and November, Dr. Bird was at the point of a breakdown to avert which he went West, then to Cape May, and finally to the Delaware Water Gap for a month in the late summer and early fall. From the Kittatinny House he sent four editorials, describing the Gap and its environs, 
that appeared in The North American, August Ioth, August 25th, September 2d, and September 8th. With the approach of the year 1854, certain changes in the conduct of the paper were suggested; among others, the paper was to be enlarged; a one-sixth share in the business was for sale and to exchange hands. To the first of these changes Dr. Bird was strongly and unreservedly opposed. It entailed added labor and expense, would probably impair the quality of the paper, and would certainly reduce the profits. Regarding the second, he objected to any exchange which had in it an element of dishonesty and should lay the firm open to the charge of double dealing. He himself had refused to purchase the share at a cut figure believing it dishonest to buy it. Upon a chance examination of the firm's accounts he found a state of affairs that must be regarded as a directly contributing cause of his death. The share in question had been secretly disposed of; fake entries of expenditures and receipts had been made to his disadvantage; and the paper against his wish and without his knowledge was being enlarged. The pain of misplaced friendship in conjunction with prolonged overwork brought on in January, I854, the fatal attack of "effusion on the brain." I

I"(Dr. Bird) wore himself out in the service of The North American. Its labors and more especially its troubles killed him. Of this I am as firmly convinced as that I survive him, and that he was cut off just as he was beginning to reap the reward of his toil." Mrs. Bird to Dr. E. R. Mayer, July 5, I854. 
The death of Dr. Bird is thus described by Dr. Edward R. Mayer, his brother-in-law, in a letter to the Hon. John M. Clayton, January 24, I854, the day after:

"You know that Dr. Bird had suffered repeatedly in the last two years from attacks of illness of a kind calculated to depress his mind and lessen the activity of all his vital powers. These were the occasion of much distress and anxiety to him not from any unworthy fear of pain, sickness, or death, but from his tender solicitude for the welfare of those who would be left behind him. These fears and a life of occupation of a sedentary kind brought about the result, which they made him apprehend and guard against. Since the first days of the present year, he had been confined to his home by a slight illness which did not attract much attention or prevent him from writing a daily editorial until Saturday the I4th instant, when he became more seriously ill. It was then discovered that he had been through his illness morbidly anxious and concerned about business matters, and that intense mental excitement acting upon a brain already weakened by depressing causes had developed dangerous disease. During the early part of last week he became more enfeebled in body and mind, and his thoughts began to wander.

"Perfectly passive and gentle, still conscious of his condition and with the presentiment that death was upon him, all the affections of his fervent, loving nature gushed out in words of endearment to his wife and child. Even his moments of delirium showed his ever present 
dread of the future that awaited those so near and dear to him, while not a word indicated a feeling of fear for himself or a thought incompatible with his unselfish and generous nature.

"On Wednesday he became much worse and I secured for him the valuable counsel of Professor Wood, who continued to visit him with me to the last. Notwithstanding active and appropriate treatment, he became daily worse and after sinking rapidly through the night of Sunday, he died yesterday morning at 9.00 of effusion on the brain."

Dr. Bird died, then, Monday, January 23, I854, at his home No. 6o Filbert Street, Philadelphia. His malady was the same as that which carried Thackeray to his grave. He was buried Thursday, January 26th, in Laurel Hill Cemetery, Philadelphia. He died, according to Dr. Mayer, intestate, leaving an estate which consisted "of a small lot of ground in New Castle yielding no revenue, and of personal property which includes one third share of The North American and Gazette and the right to a very small income from such of the works of the deceased as may be published or republished hereafter. This estate is burdened with a debt of more than $\$ 20,000$ to yourself (Clayton) and of $\$ 2000$ to a brother of Dr. Bird's." I

Robert Montgomery Bird has been dead sixtyfour years. That would not be a long time for one whose name is to live on the lips of men; it is amply

$\therefore$ Dr. E. R. Mayer to John M. Clayton. 


\section{LIFE OF ROBERT MONTGOMERY BIRD}

long to make possible a just assessment of the man and his works. The rights of personal acquaintanceship and affection have long since been honored. We are in a position to appraise the man apart as well as in relation to his time.

It cannot be said today that the name of Dr. Bird has become either widely or generally known; it can be said confidently that he is far from entirely forgotten. To the student of our native literature he holds a place of acknowledged importance. Biographical dictionaries and histories of American literature with any aim at completeness can ill afford to omit an account of his life. Any selection of representative plays or novels would do well to include work from his pen. In many libraries and literary clubs of the city of his adoption, his portrait,- - noble face, handsome though resembling in general feature that of Thackeray,-is not infrequently seen. But the name of Robert Montgomery Bird today is comparatively seldom heard. And yet, the writer strongly feels this partial disesteem is the more undeserved because the works of Bird are with many still living a vivid recollection. It is surprising how many of the generation that is passing well recall the glory of Spartacus in the hands of Edwin Forrest, John McCullough, and Robert Downing; or whose imaginations still kindle at the thought of the Jibbenainosay in Nick of the Woods. The writer was time and again struck with the number of older men, kind enough to 
answer his inquiries, who read these romances of Bird "many golden years ago" and still retain a sharp impression of the characters and their


of the author they frequently forgot. This fact, a divorce of the man from his works, marked the whole career of Dr. Bird. In Europe he naturally fared no better. In England each of his romances, as we have seen, was given at least one edition. Some of them with altered titles sold through successive editions. They may possibly have extended his reputation, but they brought him no substantial return. The only acknowledgment of his claim as author that he received from English bookmen was "four handsomely printed volumes (of Calavar) under the title of Abdalla, the Moor." ${ }_{2}$ Nick of the Woods in its German version had, according to Mrs. Bird, a sale of over ten thousand copies. This romance still occasionally issues from the American and English press in popular form. So it can be said also that if the demand for Dr. Bird's works has dwindled, it has not entirely ceased. It remains briefly to conclude regarding the place of Robert Montgomery Bird among American men of letters.

In more ways than one Dr. Bird is to be regarded as a pioneer. $\mathrm{He}$ was a professional writer in

I The late Hon. Samuel W. Pennypacker, ex-governor of Pennsylvania, is reported to have made the statement that "as a boy he sat up all night over Bird's Nick of the Woods."

${ }^{2}$ Notes of Mrs. Bird. 


\section{I56 LIFE OF ROBERT MONTGOMERY BIRD}

America before writing was a well-established profession. True, a long list of men had preceded him, who wrote and wrote well, but with few exceptions they were theologians, teachers, diplomats, or journalists, who employed the pen, to use an old figure, as a staff to walk with rather than a prop. Bird like Brockden Brown, and not much later than he, deliberately abandoned a profession to adopt literature as a career. In this sense, too, Bird was a pioneer playwright, the most considerable of that group called forth by the munificence of Edwin Forrest to lay what he hoped might prove the groundwork of a dramatic literature in America. He wrote the greatest number of Forrest's prize plays, and his work among his competitors has the strongest claims to permanence. Furthermore, he set about the work with an originality all his own. To be sure, he kept before him Elizabethan models of construction; but his central aim in The Gladiator was to fashion a part which should fit and display the individuality of the first American tragedian of his day. The perfection of that fit is amply attested by Forrest's lifelong success with the play. In Oralloossa and The Broker of Bogota as well as in Calavar and The Infidel, he still showed pioneer tendencies in pushing forth for his material, into regions and periods of history hitherto untouched in fiction.

But what of Bird's accomplishment, judged if one may use the phrase, by the national standard of achievement? To apply the absolute and to 
compare him with the greatest that have said and sung is needlessly to belittle him. The final appraisement of course must rest on the plays and romances. His verse, abundant and facile though it is, has little claim to serious consideration; it was written hastily, largely for the fun of the thing, and unwillingly owned by Dr. Bird himself. His contributions to the magazines were fragmentary and occasional; his editorials and medical writings belong elsewhere. It is by his plays and novels that we must remember him if remembered he is to be. Of his plays, then, judged by the level of American achievement in drama, four deserve preservation, Pelopidas, The Gladiator, Oralloossa, and The Broker of Bogota. Of these the second and the fourth have permanently enriched our dramatic literature: The Gladiator, because of its superb representation of physical realism, its expert portrayal of elemental man, its effective adaptation to a great actor of a certain type, and because of one scene that all but reaches a height of first power judged by what standard we will; The Broker of Bogota, for its efficient construction, its general acting qualities, and for the part of Baptista Febro, a character of remarkable veracity and scope,-hale, courteous, plain, outspoken, strong, yet weak through years and overpowering affection. It is to be recalled, too, that these two plays proved their dramatic worth on many stages in America and England as well. The part played by The Gladiator in the fame and fortune of Edwin 
Forrest we have seen. It was the play in which John McCullough first appeared as an established star, and by a coincidence the last he ever acted. ${ }^{x}$

The prose romances of Dr. Bird, too, represent a solid achievement. They belong, it is true, to a category which precludes them from the rank of those great novels that bring to their readers a world message. Like many of Scott and Cooper they are essentially boys' books. A fresh illumination of the meaning of life is not their aim. And yet they have just claims to virtues that should once and for all discourage invidious comparisons, as have been made, between them and the 'dimenovel." Like those of his two great forerunners and no less than theirs, the novels of Dr. Bird represent conscientious workmanship. This workmanship in the case of his Mexican romances was carried to such a point of accuracy as to win commendation from expert historians of the period. "Dr. Bird in his picturesque romance of Calavar," says Prescott in his Conquest of Mexico, "hasstudied with great care the costume, manners, and military uses of the natives. He has done for them what Cooper has done for the wild tribes of the North,touched their rude features with the bright coloring of a poetic fancy. He has been equally fortunate in his delineation of the picturesque scenery of the land." 2 Again the novels of Dr. Bird with-

I For an account of McCullough as Spartacus see Winter, The Wallet of Time, vol. i., pp. 271-273. He first played the part in New York, May 4, 1874 .

iVol. ii., p. 336, footnote. 
out exception of a single chapter are thoroughly wholesome. A perfect purity sweetens every page. His characters have a hardihood and strength that invigorate like those of Scott's. The scenes of his novels are often in mountain passes and malarial swamps; their concern, mainly with the roughest adventure; but his men and women are free from the slightest taint of pruriency. They are often cruel, barbarous, deceptive; they are always robust, elemental, wholesome. And finally there is the tribute of the style of these books, undeniably diffuse and prolix at times, but often neat, fluent, melodious, vividly pictorial and dramatically intense.

Finally, of Dr. Bird's lovable character as a man, of his extraordinary capacity for friendship, of his idealism, and the princely qualities of his heart, there can be no better statement than that of a contemporary and associate, who at the time of his death thus wrote of Dr. Bird. After mention of his rich endowments he continues: "Nor had nature been less munificent in the qualities of his heartwhich was great with great virtues-chivalric in its courage, soft in its gentleness, liberal, loyal, loving. It is a grief to lose, from the scenes of life, such a nature; but it is a triumph that such a nature has lived, and been with and of us, and shall, we trust, be so again." $\mathrm{x}$

'The North American and United States Gazette, January 24, I 854 . 



\section{APPENDIX A}

The following is a list of the American and European editions of Bird's romances, in the order of their writing.

\section{AMERICAN EDITIONS}

Calavar: or, The Knight of the Conquest; a romance of Mexico. Philadelphia, Carey, Lea \& Blanchard, 1834. 2 vols. $12^{\circ}$. [Another Edition.] 1837.

Calavar; or, The Knight of the Conquest; a romance of Mexico. By R. M. Bird. A new ed. Philadelphia, Lea \& Blanchard, 1847. 2 vols.

Calavar, a Romance of Mexico. New York, J. S. Redfield, 1854. $12^{\circ}$.

Calavar, The Knight of the Conquest. I11. W. J. Widdleton, 1876 . $12^{\circ}$.

The Infidel; or, The Fall of Mexico. A romance. By the author of Calavar. Philadelphia, Carey, Lea \& Blanchard, 1835 . 2 vols. $12^{\circ}$.

The Hawks of Hawk Hollow. A tradition of Pennsylvania. By the author of Calavar. Philadelphia, Carey, Lea \& Blanchard, 1835. 2 vols. $12^{\circ}$.

Sheppard Lee. Written by himself. New York, Harper \& Brothers, 1836. 2 vols.

Nick of the Woods, or, The Jibbenainosay. A tale of Kentucky. By the author of Calavar. Philadelphia, Carey, Lea \& Blanchard, 1837. 2 vols. $12^{\circ}$.

Nick of the Woods; or, The Jibbenainosay. A tale of Kentucky.

By Robert Montgomery Bird. A new ed., rev. by the author. New York, J. S. Redfield, 1853. 2 pt. $12^{\circ}$.

Nick of the Woods; or, The Jibbenainosay. W. J. Widdleton, $1876.12^{\circ}$.

Nick of the Woods. Burrows, 1904. $12^{\circ}$.

Nick of the Woods. A story of the Early Settlers in Kentucky, A. L. Burt, 1905. $12^{\circ}$. 
Peter Pilgrim; or, a rambler's recollections. By the author of Calavar, Nick of the Woods, etc. Philadelphia, 1838. 2 vols. $12^{\circ}$.

The Adventures of Robin Day. By the author of Calavar. Philadelphia, Lea \& Blanchard, 1839. 2 vols. $12^{\circ}$.

The Adventures of Robin Day. Philadelphia, Lea, 1839. 2 vols. $8^{\circ}$.

\section{ENGLISH EDITIONS}

Abdalla the Moor and the Spanish Knight: A romance of Mexico. London, Newman, 1835. 4 vols. $12^{\circ}$. [The original title was Calavar.]

The Infidel; or, The Fall of Mexico, London, $1835 . \quad 12^{\circ}$.

Cortes; or, The Fall of Mexico: A romance. Bentley, 1835. 3 vols. $12^{\circ}$. [The original title was The Infidel.]

Cortes; or, The Fall of Mexico. London, 1835. 3 vols. $12^{\circ}$. [The original title was The, Infidel.]

The Hawks of Hawk Hollow. Bentley, 1837. 3 vols. $12^{\circ}$.

The Hawks of Hawk Hollow. By Dr. Bird. London, Ward \& Lock, $1856.8^{\circ}$.

Nick of the Woods, a story of Kentucky. By the author of Spartacus, etc. Edited by W. H. Ainsworth, London, 1837 . 3 vols. $8^{\circ}$.

Nick of the Woods. Bentley, 1837. 3 vols. $12^{\circ}$.

Nick of the Woods. London, 1854. $16^{\circ}$.

Nick of the Woods; or, Adventures of Prairie Life. By Robert M.

Bird. London, Ward \& Lock, 1856.

[Another Edition.] $1860.8^{\circ}$.

[Another Edition.] 1872. $12^{\circ}$.

Nick of the Woods; or, Adventures of Prairie Life. Routledge, I883. $8^{\circ}$.

Nick of the Woods; or, Adventures of Prairie Life. London, Nicholson. $12^{\circ}$. (Contains also Daniel Wise and Ashcourt Roderick.)

Peter Pilgrim, a Tale. Bentley, 1839. 2 vols. $12^{\circ}$.

\section{GERMAN EDITION}

Die Gefahren der Wildnis. Eine Erzählung für die reifere Jugend. Nach dem Englischen [Nick of the Woods] bearbeitet von Franz Hoffmann. Mit Bildern. Stuttgart, 1847. $8^{\circ}$. 


\section{APPENDIX B}

The following is a complete list, chronologically arranged, of Bird's contributions to magazines:

Fount of Blandusia. A poem, translation from Horace, in Philadelphia Monthly Magazine, October, 1827.

Saul's Last Day. A poem in Philadelphia Monthly Magazine, October, 1827.

The Dying Bride. A poem in Philadelphia Monthly Magazine, November, 1827. It is signed B., like other of his verse, and is probably Dr. Bird's.

The Miniature. A poem in Philadélphia Monthly Magazine, November, 1827 .

The Dead Soldier. A poem in Philadelphia Monthly Magazine, November, 1827 .

The Death of Meleager. A poem in Philadelphia Monthly Magazine, December, 1827.

Rest in Thine Isle. A poem in Philadelphia Monthly Magazine, December, 1827 .

The Ice Island. A tale in Philadelphia Monthly Magazine, December, 1827 .

The Spirit of the Reeds. A story in Philadelphia Monthly Magazine, January, 1828.

Friendship. A poem in Philadelphia Monthly Magazine, January, 1828 .

The Phantom Players. A tale in Philadelphia Monthly Magazine, May, 1828.

Changing Heart, Away from Me. A poem in Philadelphia Monthly Magazine, July, 1828 .

To Lyce. A poem, translation from Horace, in Philadelphia Monthly Magazine, August, 1828.

Brunette. A poem in Philadelphia Monthly Magazine, August, 1828.

Summer. A poem in Philadelphia Monthly Magazine, August, 1828.

The Helots. A poem in Philadelphia Monthly Magazine, September, $\mathbf{1} 828$.

The Love Sick Minstrel. A poem in Philadelphia Monthly Magazine, September, 1828 . 
She opes her eyes and oh my bosom's swell! A poem in New

York Mirror, May, 1832.

Mary. A sonnet in the New York Mirror, May 12, 1832.

The Beech Tree. A poem in New York Mirror, March, 1834.

The China Tree. A poem in Knickerbocker Magazine, January, 1835 .

To Governor M'Duffie. A poem in New England Magazine, February, 1835 .

An Evening Ode. A poem in Knickerbocker Magazine, February, 1835, and also in The Commercial Herald.

Ode to the Sycamore. Written for the Buckeyes' celebration of the 47th anniversary of the Landing at the mouth of the Muskingum River, Ohio, April, 1835.

Community of Copy-Right. An Article in Knickerbocker Magazine, October, 1835 .

An Address. A poem in National Gazette, January, 1836. It was written for and delivered at the Wood Complimentary Benefit.

Lament. A poem in United States Gazette, April, 1837.

The Mammoth Cave of Kentucky. A descriptive article in American Monthly Magazine, May and June, 1837. This was later incorporated in Peter Pilgrim.

A Tale of a Snag. A story in American Monthly Magazine, August, 1837. This was later incorporated in Peter Pilgrim. The Extra Lodger. A story in New York Mirror, November 10, 1838. It had already appeared in Peter Pilgrim.

God Bless America. A poem.

Romance of Cid Ramon. A poem. Printed from Calavar.

The Belated Revenge. A story (partly by Frederick Mayer Bird) in Lippincott's Magazine, November, 1889.

\section{APPENDIX C}

\section{MISCELLANEOUS PUBLICATIONS}

Valedictory address delivered before the graduates of Pennsylvania Medical College: session of 1842-43. Philadelphia, Merrihew, 1843. $8^{\circ}$. 
A Belated Revenge. Philadelphia, Lippincott. [This was begun by Dr. Bird under the title of Ipsico Poe, The Long Hunter, and written to Chapter XV., at which point his son took it up and completed it. It was first published as "A Belated Revenge" in Lippincott's Magazine, November, 1889.]

The Broker of Bogota, a tragedy in five acts. Printed in Quinn, A. H., Ed., Representative American Plays. New York, 1917.

\section{BIBLIOGRAPHICAL NOTE}

Without pretending to be exhaustive, the following is a list of readily accessible books that should serve as guides to those who desire further to investigate the period covered by Dr. Bird's life.

Adams, W. Davenport. A Dictionary of the Drama. Philadelphia, I904.

Alger, William R. Life of Edwin Forrest. 2 volumes. Philadelphia, 1877 .

BarRetT, LaWrence. Edwin Forrest. Boston, 1882.

Beers, H. A. Nathaniel Parker Willis. Boston, I885. "American Men of Letters."

Brown, T. A. A History of the New York Stage. From the First Performance in 1732 to I901. 3 volumes. New York, 1903.

CaIrns, W. B. On the Development of American Literature from I8I5 to I833. With Especial Reference to Periodicals. Madison, Wisconsin, $\mathbf{1} 898$.

Clarence, Reginald T. The Stage Cyclopedia. London, 1909. Coad, Oral Sumner. William Dunlap. Dunlap Society Publications. Series 3, volume 2.

Conrad, Henry Clay. History of the State of Delaware. 3 volumes. Wilmington, Delaware, 1908.

Dunlap, William. History of American Theatre. New York, 1832. 2 volumes. London, 1833.

Durang, Charles. The Philadelphia Stage. From the year 1749 to the year 1855. Partly compiled from the papers of his father, the late John Durang; with notes by the editors 
(of the Philadelphia Sunday Dispatch). Published serially in the Philadelphia Dispatch as follows: First Series, 17491821 , beginning in the issue of May 7, 1854 ; Second Series, 1822-1830, beginning June 29, 1856; Third Series, 18301855, beginning July 8,1860 .

GRIswold, R. G. Prose Writers of America. Philadelphia, 1847.

IRELAND, J. N. Records of the New York Stage, from 1750 to 1860. 2 volumes, New York, 1866-67.

Lounsbury, Thomas R. James Fenimore Cooper. Boston, 1883. "American Men of Letters."

McCullough, BruCE WelKer. The Life and Writings of Richard Penn Smith. With a Reprint of His Play, The Deformed, 1833. A Pennsylvania Thesis, 1917.

Moses, M. J. The American Dramatist. Boston, I9II.

Moses, Montrose J. Famous Actor Families in America. New York, 1906.

Murdoch, James E. The Stage, or Recollections of Actors and Acting from an Experience of Fifty Years. Philadelphia, 1880.

Oberholtzer, Ellis Paxson. Philadelphia; a History of the City and Its People, a Record of 225 Years. Philadelphia,

- 1911.

- Literary History of Philadelphia. Philadelphia, 1906.

Quinn, Arthur H. "The Early Drama, 1756-1860," in The Cambridge History of American Literature, volume i., p. 215.

- Representative American Plays. New York, 1917.

ReEs, James. The Dramatic Authors of America. Philadelphia, 1845.

- The Life of Edwin Forrest. Philadelphia, n. d. [1874].

Sartain, John. Reminiscences of a Very Old Man. New York, 1900.

Seilhamer, G. O. History of the American Theater. 3 volumes, Philadelphia, 1888-91.

Smyth, A. H. The Philadelphia Magazines and Their Contributors, I74I-I850. Philadelphia, 1892.

Trent, William P. William Gilmore Simms. Boston, 1892, "American Men of Letters."

Tuckerman. Life of John Pendleton Kennedy. New York, 1917. 
Tyson, J. R. Sketch of the Wistar Party of Philadelphia. Philadelphia, 1898.

Wallack, Lester. Memories of Fifty Years Ago. New York, 1889.

Wemyss, F. C. Theatrical Biography of Eminent Actors and Authors. New York [185-].

Twenty-six Years of Life of an Actor Manager. 2 volumes. New York, 1847.

Chronology of the American Stage from 1752-1852. New York, n. d. [1852].

Winter, William. The Wallet of Time, Containing Personal, Biographical and Critical Reminiscences of the American Theater. 2 volumes. New York, 1913.

- Other Days; Being Chronicles and Memories of the Stage. New York, 1908.

Wood's Diary. A Manuscript Diary or Daily Account Book of W. B. Wood, in 9 volumes, extending from 1810 to 1835 . (In Library of the University of Pennsylvania.)

WooD, W. B. Personal Recollections of the Stage . . D During a Period of Forty Years. Philadelphia, 1835.

Woodberry, George E. Edgar Allan Poe. Boston, 1885.

"American Men of Letters." 



\section{PART Il}

\section{DRAMATIC WORKS}





\section{PELOPIDAS}

The texts of the following plays are in each case based on manuscript copies in the collection of Bird papers recently presented to the Library of the University of Pennsylvania by the grandson of the author, Mr. Robert Montgomery Bird, of Bethlehem, Pennsylvania.

The present text of Pelopidas is that of the best and fullest autograph copy in the Bird collection. There are two other complete autograph manuscripts of the play. Pelopidas was finished in the fall of 1830. Although it was accepted by Edwin Forrest as a prize-play, it was never produced on the stage. 



\title{
PELOPIDAS
}

\author{
OR \\ THE FALL OF THE POLEMARCHS
}

A TRAGEDY

IN FIVE ACTS

$$
1830-1840
$$




\section{PELOPIDAS}

\section{Persons Represented}

Leontidas, a Theban, (The Polemarchs, or Tyrants,

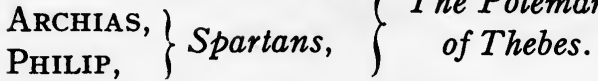

Philidas, their Secretary.

Melon, nephew of Philidas.

HipPoclus, father of Pelopidas.

Charon, a Theban, friend to Pelopidas.

PELOPIDAS,

DAMOCLIDEs, $\}$ Theban Patriots.

LAON, and others.

Hylas, a boy, son of Pelopidas.

LYCOPHRON, son of Charon.

Sibylla, wife of Pelopidas.

Guests, Soldiers, Musicians, Dancers, Slaves, \&c.

SCENE-At first, Athens: afterwards, Thebes in Baotia. 


\section{PELOPIDAS}

\section{ACT I}

SCENE I. Athens. The Acropolis. (Enter LAON, DAMOCLIDES, and other Theban Exiles.)

LAON

No hope for Thebes? Still trampled by her tyrants! And Athens hath no arm of help for her That help'd herself from bonds,- - no sword to strike The enemy that, of late, her own towns master'd, And ground her sons in slavery, - hated Sparta! This is the virtue, then, of Athens; where, Scarce lodged and countenanced, scarce guarded from The assassin knives with which our foes pursue us, We drag out painfully a life of exile, Martyrs of freedom. No, there is no hope, While Athens still denies us.

DAM .

Long as Pelopidas is with us! Yield There is hope, All to despair,-while still I see his eye Set upon yonder mountains, which enclose Our fallen city, and in that eye the look Of a true Greek and Theban, I will hope, Though against hope. Believe me, he will yet Move the Athenians. 


\section{LAON}

By Minerva, no!

Witness the anger of her Senators, When her brave youth, leaping at our first call, Offer'd their friendly swords to strike for Thebes; What said the Senators?-Athens is at peace, And Sparta her ally.

DAM.

This was, good Laon,

Their public voice; and policy required it. They give Pelopidas better hope in private.

\section{LAON}

How much of hope? A promise to permit Their youth - the fiery band that burn to join usTo march to Thebes when-we have conquer'd it! This is but mockery: Give us Thebes, and what Care we for help from Athens?

DAM.

I would, i'faith,

They were less politic. But set thine eye Upon Pelopidas: hope flies not him:

There's something stirs within him; some brave vision Is opening on his mind,--some glorious thought That speaks of Thebes and freedom. Yestermorn He was as sad as thou, and on this rock Sat weeping for his country;-it was when He heard of Philidas, his old friend's defection, (That traitor whom the Polemarchs reward For his apostacy with the highest office Near to their persons:) but at night I found him 
Transform'd in look and spirit,-no more an exile Pining with sorrow, but a Theban chief, With flashing eye, and warrior tread, and look Of angry joy;-e'en just the man I saw him On his first field, the gory Mantinea, Hewing his path through ranks of death, and winning That fame which makes him, though the youngest here,

First of all Thebans. Be sure, that change denotes us Something of good. Athens, perhaps, relents, And grants us succour.

\section{LAON}

Would it were so-But lo!

Where is that fire you boasted? See, how dark And wild his aspect!

DAM.

Dark and wild, I grant you,

But yet not mournful!-

\section{(Enter PELOPIDAs.)}

DAM.

What, Pelopidas!

PELOP.

Damoclides!-

Are all here Thebans?
DAM .

All. 


\section{PELOP.}

Ay!-Laon, Theopompus,

Chlidon-true Thebans all!-I would not have A stranger hear us, - there are spies about us.News, friends!-What, are ye ready? Grind your swords,

Buckle your armour, mount your steeds: the time Has come for action. - Which of you will ride With me to Thebes?

DAM.

I!

ALL

I!

DAM.

Hath Athens granted forces?

But, pray you, speak.

\section{PELOP.}

Not a man;-

Save on her hard original conditions.

We for ourselves must toil. Think not of AthensThe gods are with us.

\section{LAON}

With the gods to aid us-

And a battalion of Athenians-

Thebes were our own. But with the gods alone, And our poor selves,- - four hundred naked exiles,What can we make against a garrison'd city, Where even our friends are turn'd against us? 
PELOP.

What!

Thou think'st of Philidas? I, too, thought him traitor,

Bought to the service of the Polemarchs;

And this unnerved me. By the gods! 'tis better

To find the man we have call'd friend, and known

A noble one, stoop down to baseness.-But Philidas

Was never a traitor! Hark! I wept my friend,

Thus turn'd a villain; when this letter reach'd me,

By his own true hand written,-Philidas

Is yet the friend of Thebes.

\section{LAON}

Believe him not,

Without a pledge.

\section{PELOP.}

He gives it, in a caution

Worth twenty oaths of zeal: Beware, he writes, Of Iphias, the Athenian.

\section{LAON}

What! the pontiff,

Who, ever, seems our truest friend?

\section{PELOP.}

A false one!

Through him our subtlest plans have reach'd the tyrants,

Through him their daggers strike us: Oh, believe me, What Philidas writes of him I have proved true. 
But, we've no time for words. - A second missive Reach'd me, to-day, by a true messenger, Who bears, already, an answer back to Thebes. Hark, in a word;-this Philidas, who, by craft, Works in our purpose, (and, for that end, has wound Into the tyrants' favours,) has entrapp'd them Into our hands: They feast with bim to-night: We must feast with them!

\section{LAON}

We!

\section{PELOP.}

All is prepared,-

The messenger sent back; and we, at midnight, Enter the city: at the Delian Gate, A friend receives us.

\section{LAON}

This is hasty!

PELOP.

Laon,

He that strikes tyrants must arm with thunderbolts!There is no time for counsel. He that loves Thebes Better than life, let him ride forth with me To slay her despots. Twelve of us alone Enter the city, (we must begone at once:) The rest, set out at nightfall, and take post Upon the Hill of Fortune; whence, that instant The Polemarchs have fallen, we summon them To storm the citadel. 
DAM.

I, for one, love Thebes

Better than life-Have at the Polemarchs!

\section{THE REST}

And I-and I-and I!

\section{PELOP.}

Why there spoke men!

True sons of Thebes and freedom!-Thou, Laon, With the four hundred follow.

\section{LAON}

The thing is hasty, as I said; but I

$$
\text { By Jove, not I! }
$$

Yield the bright place of fame to none. Forgive me; I'll have the first blow at the knaves!

\section{PELOP.}

Brave heart,

I knew thou wouldst not fail me! Be it so. Haste to your steeds : let no one know, in Athens, That you have left it: steal, one by one, away, And meet upon the road a league from Athens. Thence, all assembled, we set out together To do a deed of virtue, that shall keep, Throughout all time, our memories green and glorious!

(Exeunt.)

SCENE II. Thebes. A room in the house of Philidas. A storm of wind heard without. (Enter Philidas and Charon.) 


\section{CHAR.}

Said ye, to-night!

PHIL.

Ay, noble friend, to-night:

To-night the princely masters of Bœotia

Feast with their honoured slave. Do not the fates

Smile on us, Charon?-Ay! these crafty fools,

That play so deeply on my gratitude,

Calling me Secretary and their friend,

Come blindly to the toils. They feast with me!

Is't not enough? The exiles are at hand,

Pelopidas their head-'Tis but a blow;

And revelry and bondage end to together!

\section{CHAR.}

Yet we have no advices.

\section{PHIL.}

Have we not!

What, when the gods reveal their favour to us! The exiles come-You cannot think that Heaven Vouchsafes us these brave presages for laughter?

A multitude-ay, the whole city-saw it;Three ravens croaking o'er the citadel, And filling all the air with their harsh clamour:

Did not the rabble call them Polemarchs? And when the eagle pounced upon, and tore them, The veriest varlets cried, Pelopidas!

\section{CHAR.}

Would he were come, and come the great avenger Of his oppressed and outraged countrymen: There's no Bœotian but will follow him. 


\section{PHIL.}

He will! And, in reliance on his wisdom, I have sent him word of this our festival. Already, on the road, my nephew Melon Lies waiting him, to bring him to the city.

\section{(Enter MELON.)}

What! you have brought them!

CHAR.

Have you found them?

MEL.

No:

I found an open and a desolate road, A gate unguarded;-a brave opportunity!

A thousand men might pass it unmolested. The river thunders o'er his rocky bed; Old CEolus, with his gusty myrmidons, Howls uproar through the air; and all the stars Shroud them in dismal sleety clouds. - A rare Fine night for mischief! but the makers come not!

\section{CHAR.}

Hark to the knave. For mischief! He looks on A deed which, at the least, slays many men, And may slay thousands, as a mischief-making!

\section{MEL.}

Is it not, Charon? I'll not dignify it With any of your sounding names. Are tyrants Moulded of better clay than other men? 
Their souls of passions less corrupt and base Than the vile fires that fill a common breast?

What is there, then, to mark a tyrant's fall,

Nobler than marks the death of other men?

Give them their names,- great rogues, - the deed that slays them

Is but rogue-killing. But thousands fall with them!

Well, what of that? a thousand baser rogues,-

Slaves that support them, or endure their rule!

Kill me ten thousand such, 'tis still rogue-killing.

You twain the deed may call an act of virtue:

To me 'tis mischief-making.-

\section{PHIL.}

\section{Omens lie not:}

The messenger was faithful!-Foolish nephew, Get thee to horse again, and to the highway: There posted, a true sentry, wait the coming Of those thou wot'st of.

\section{MEL.}

Why, they ne'er will come!

In such a night as this, a winter storm Howling and freezing, no man can tread the paths O'er our rough mountains.

\section{PHIL.}

No man that fears, like thee, To face the blast. Sirrah, I do distrust thee! This cold sleet drove thee from thy post, where now Our brave friends wait thee. What, effeminate boy, Canst thou, who fly'st before a winter wind, E'er hope to face a Spartan? 
MEL.

I am ready

To face a dozen; ready, too, and able, Of mine own self, to do this perilous act, You think so grand and virtuous!

CHAR.

The Polemarchs?

$$
\text { What, to kill }
$$

MEL.

They banquet with my uncle.

Make me their cupbearer-An ounce of hemlock

Were better than a thousand patriots!

What hinders, then, to knock their guards o' th' head,

Rouse up the growling citizens, besiege, And starve, the garrison in the Cadmea?

\section{PHIL.}

Thou speak'st a boy, although a brave one.-Hence To th' gates, and to Pelopidas; with whom, (A follower, where to follow is distinction,) Thy life of manhood thou shalt well begin, With hope to end in glory. To the gates, There to await the exiles.

CHAR.

And, hark ye, Melon:

When found, conduct them to my house,-their harbour

And fortress, till the hour of blood be come. 


\section{I86 DRAMATIC WORKS OF ROBERT BIRD}

MEL.

Safely and secretly!

(Exit.)

PHIL.

I pray, have ready

A store of weapons; for, 'tis like, they dare not Enter in arms.

( $A$ clatter of arms is heard without.)

CHAR.

Hark!

PHIL.

'Tis the Polemarch!

My patron Archias! This bodes us news From Athens!

(Enter ARCHIAs, attended.)

Hail, my prince and princely patron! The gods befriend me in your countenance.

ARCH.

Our faithful Philidas.-And Charon, too, Of the best blood of Thebes,-methinks, as faithful?

CHAR.

Ever your highness' slave.

ARCH.

We hope, some day,

Charon will use a nobler name,-our friend. 


\section{CHAR.}

Your highness would be with the Secretary.

I humbly take my leave.

(Exit.)

\section{ARCH.}

\section{A hypocrite!-}

But then all men are so: an enemy, It may be;-but to be the foe of power, Needs a great heart of courage! I do think him A friend (but, mark, in secret,) of the exiles; Perhaps that one (yet he hath scarce the spirit,) Of whom the pontiff speaks, -an unknown traitor, That hath sent letters to Pelopidas.

\section{PHIL.}

Is there such man in Thebes?

\section{ARCH.}

So Iphias writes me;

But who he knows not: and Iphias hath his eye Upon the exiles.-What, by Jove! I tell thee, Ere we yield up to pleasure, we must counsel Of the state's danger!

PHIL.

If it please my prince.

\section{ARCH.}

Know then, 'tis certain, (Iphias so reports it) Those banished traitors, whom (their chiefs cut off, None left them but the hot Pelopidas,) We deemed so lightly of, a broken faction, 
Impotent and despairing, have roused up

Into new life and energy, (as serpents,

That sleep through winter in the spring arise

Stronger in venom,) and straightway set their brains

To plot new treasons. Some friend in Thebes (the knave

Shall feed the jackals!) sends them hope and counsel:

It was but yesterday, his courier (seen

By Iphias' spies,) bore letters to Pelopidas, And, with his charges, fled from Athens.

PHIL.

This

Calls for new vigilance. But did the pontiff Ravel the secret of the plot?

ARCH.

The traitors

Bear it too subtly. Yet something he hath learn'd; And he suspects,-nay, is assured, (so hotly Despair and their mad leader urge them on,) They scheme (what think'st thou?) a return to Thebes; Here, in the tyrants' den, to beard the tyrants And strike the blow for-faugh!-for liberty.

\section{PHIL.}

This is most frantic!

\section{ARCH.}

And most fortunate:

It brings them in our power. While Iphias sends us Word of their movements, we set our cunning traps, And their first step in Thebes is-on the scaffold! 
PHIL.

Mad traitors they! And this bold visit when Make they, or meditate?

\section{ARCH.}

Full soon, says Iphias;

Yet knows not: on the morrow, we shall hear; Or soon as Iphias penetrates their secret.

\section{PHIL.}

Why then, most sure, the villains seek their death. Methinks, I see a way to lure them on Into the ready nets.

\section{ARCH.}

There spoke my Philidas!

To whom (for well I know, he hath a soul Full of all policy,) in such a strait, I come for counsel, rather than to my colleagues. Alas, thou know'st, to be a prince, is not To be a capable governor: (to thee, Who art my friend, I can speak plainly.) Fate Hath cursed me with associates all unfit For their high function. Dost thou think, that Philip,-

That thing of croaking fear and superstition,Could aid, in such conjuncture? Or Leontidas?Alas! when Sparta, from her Theban friends, Chose a third Polemarch, she sought not out The best and wisest; or her choice had ne'er Fall'n on Leontidas, - a man of pleasure, Who, on Sibylla's wanton lap, would rather Dream a charmed life away, than rise in arms Against her traitor husband. 
From such weak coadjutors, I must turn To my best friend and counsellor, Philidas;

On whose wise policy I rely, to bring These dark affairs to issue.

PHIL.

Would I might prove Worthy your highness' praise.

ARCH.

Catch me these knaves;

Or but their chief, Pelopidas; (the rest Are but his tools and weapons-naught without The hand that wields them:) and look (if Archias Hath credit yet with Sparta,) soon to sit In the chair of Leontidas.

PHIL.

My wishes

Aim at no higher office than to serve My most magnificent patron. But these traitors! What if we send some seeming friend to them, To urge them in their purpose?

ARCH.

If Iphias err not,

They need no spur. The danger lies in this,That, by a sudden frenzy goaded on, They may leap on us ere we have warning.

PHIL.

Give me

Power o'er the guard: I'll have the gates so watched, No man shall pass without my eye upon him. 


\section{ARCH.}

It shall be so! I'll serve thee and myself, In the same act. The gallant youth, thy nephew, Shall be made Captain of the Guard.

$$
\text { PHIL. (Aside.) }
$$

The gods

Make them their own destroyers!-A wild youth, But brave and trusty; and for his faith I'll answer As for-my own.

Our officer.

ARCH.

To-morrow, then, shall see him

PHIL.

To-night, my prince, to-night!

Who knows what deeds this night may see attempted?

What if the traitors should set forth to-night?

ARCH.

Thou hast no fears of that?

PHIL.

No fears, my prince:

But the wise fight 'gainst possibilities.

ARCH.

I like thy zeal: it shall be as you wish.

Have the youth in attendance at the banquet, To take his sword of office. 
192 DRAMATIC WORKS OF ROBERT BIRD

PHIL.

My prince's slave!

ARCH.

And hark ye, Philidas, - I mean to prove

My friendship further. That unknown knave in Thebes

In correspondence with the traitors,-couldst thou Believe that man was Charon?

PHIL.

I think him faithful.

Charon, my prince!

ARCH.

By my life, not I.

He hath the means to stir the people,-look you, This discontented rabble; which, averse To our authority, a rich man's gold May easily bribe to riot.

PHIL.

Alas, your highness,

I ever held him ranked among your friends.

\section{ARCH.}

We'll have no friends with means to be our foes. His wealth is dangerous, and should be owned By trustier friends. Dost thou conceive me, Philidas? Fasten on him (for thy shrewd wit may do it,) A charge of correspondence with the exiles,And thou art heir to half his wealth. 
PHIL.

Already on the block!

I see him

\section{ARCH.}

Why, then, for pleasure!

The state is served; Archias may now unbend, And play the reveller, like any Theban. Fools, like Leontidas, may give their souls, And every thought, to pleasure, till the sense Surfeits and sickens o'er the constant feast: Better a Spartan knows, who, with denial And toil, his eager passions keeps alive, Ever with fullest appetite for bliss.

This night to pleasure, then, my Philidas! Spread ye the board with dainties rich and rare; Your halls with dancers and musicians fill; And Thebes' best beauties summon to the feast, To crown with love and joy their Polemarchs.

\section{PHIL.}

Dainties of every clime shall spread the board: Fine dancers and musicians fill the halls; And the most beauteous dames of Thebes appear, To crown with love and joy their Polemarchs!

(Exeunt.)

SCENE III. Under the walls of Thebes. A storm blowing. (Enter DAMOCLIDES, LAON, and other exiles (eleven in all,) as Hunters, in skin cloaks.)

DAM.

Be of good heart. I warrant me, our leader Will find us hope, even in this misadventure. 
'Tis strange.

\section{IST EXILE.}

\section{LAON}

What! that we are under our own walls, And something doubtful, like to whipt out curs, Whether to enter!

DAM.

Friends! ye are discontented! This speaks not well for Thebans. Will ye shrink From the bold deed that frees a bleeding country, Which ye have sworn so often to achieve?

\section{LAON}

Shrink! If you put me once but on the track Of a Spartan, peasant be he or Polemarch, And find me shrink from following, proclaim me A braggart. But to be kept here, exposed To biting tempests, and to feel the strength Which should be spent upon our enemies; Wasting before a north-wind, while the tyrants Are feasting warmly in our palaces; This moves me. And no villain messenger To bid us to the city! Is this juggling? Or are our colleagues in the city cowards? Who'll answer for their spirit or their faith?

\section{(Enter Pelopidas.)}

\section{PELOP.}

I, Laon!-This unbecoming peevishness, Which rashly charges a long trusted friend 
With an unworthy motive, is unworthy.

Fy! you know not how many eyes are set

On the obscurest citizen of Thebes:

Think'st thou the titled Philidas is unwatched?

And who will warrant, mine own messenger

Has yet found opening to approach him?

\section{LAON}

Therefore I yield me petulant and rash.

True:

But the main cause of trouble still remains:

What's to be done? Without advices, shall we

Break a gate open with our fists, and fight,

We twelve, against their thousands? Or remain

Here on the road, warming ourselves with fury,

Till morning mars us? Or retire to Athens,

To meet the laughter of her citizens,

And the hireling knife and poison of assassins?

\section{PELOP.}

To enter unadvisedly were death;

To pause, the same; but to retreat were worseThat were dishonour. At the Delian Gate I looked to find a friend: this charged I Philidas. No man is there,- -none save the drowsy warders, Whom 'twere not hard to pass, were't wise to pass. Whate'er the luckless cause of this mishap, 'Tis most unfortunate,-yet must not stay us. The steel that rids our country of her tyrants Must strike to-night, or never. Be assured, The spies and murderers that, like vultures, hung Upon our exiled paths, and made, in Athens, The firesides of our friends as perilous to us 
As Theban prisons, have, ere now, discovered Our flight from Athens, and advice despatched To the three tyrants. - What! we must forestall them.

But how?

\section{LAON}

\section{PELOP.}

One of us, venturing for the rest, Must pass the gate, and seek our friends.

\section{LAON}

And who

Will undertake this madman's enterprise?

I say naught of its peril; since not that

Would hinder me. But, as ten thousand chances

Make against one, that he who volunteers it, Falls in the tyrants' hands, and thus, not only Brings death upon himself and all that follow, But ruins our poor country's latest hope,I think, none here will choose to be that one.

\section{PELOP.}

Thou art deceived; myself will be that one! It is an office of honour which I covet Next unto that of striking the first blow: And whatsoe'er betide myself, I swear By Pluto, never a man here standing by me Shall rue the enterprise. Lie here in wait. If there be yet in Thebes a friend of Thebes, Ye shall full soon be sent for. For myself, Expect me not. When I set out from Athens, I made my vow to Jove,- and here repeat it,Once enter'd that wronged city, ne'er again To leave it, living, whilst a tyrant lives. 
DAM.

May the gods speed ye, who have raised ye up To be our leader! We will trust our lives And honours in your keeping.

\section{LAON}

Ay, Heaven speed ye!

A man may grumble, and be honest too. But pardon a weak jealousy, which I Must utter:-In yon city, noble friend, You may find many valiant spirits, ready To join and strike with you.

PELOP.

I hope so, Laon.

\section{LAON}

If you do take them with you to the act, Forgetting us to whom the deed belongs, Robbing us of the honour-

PELOP.

Never doubt me:

You shall be sent for presently, and find Friends to support, not to precede ye.

\section{LAON}

I am content.

PELOP.

Let one be ready with the fleetest horse, That moment my messenger reaches ye, to spur 
To th' Hill of Fortune for our friends; and thence To Athens, to bring on the band of youths, Allowed to march, when we have won the cityAnd we shall win it. We must have assistance, At dawn, to invest and storm the citadel. To-morrow's eve must find no warring Spartan Breathing in Thebes.

DAM.

This shall be done.

PELOP.

And when

Ye follow him that I shall send for you, Be it in silence and simplicity, As huntsmen still. Let no one straggle from you, To visit his home; but follow sternly on To where brave deeds and everlasting honour Await you.

DAM.

This is well.

\section{PELOP.}

And hark ye, friends.-

Since the gross cunning of a silly peasant

May trap a tiger, a mere man, like me, May chance upon some pitfall, which the craft Of yonder tyrants hollows in our path.

\section{LAON}

Well! Doth Pelopidas talk of peril? 
PELOP.

Ay:

Why should I not? I have a wife, brave Laon:

A boy, too, who, if the great gods but spare him, Will one day spit at Spartans.-

DAM.

Noble friend,

Rest you content. There's never a Theban here Will e'er desert them.

PELOP.

And my gray old father?

DAM.

He shall be ours.

PELOP.

Why then this feat is nothing!

I shall now think of naught but Thebes.-Farewell: $\mathrm{Be}$ of good heart, and ready.-Farewell, farewell. This night ye banquet with the Polemarchs!

(Exeunt.)

END OF ACT I. 


\title{
ACT II
}

SCENE I. A room in the house of PELOPIDAS. (Enter Sibylla, leading the boy Hylas, and followed by a Female Slave.)

SIBYLLA

Go,- -get thee hence, and let me hear no more. Go, go!-The gods desert me!-Hence, I say. I will not see him.

(Exit Slave.)

\author{
HYL. \\ Mother!
}

SIB.

My loved boy!

HYL.

Mother, you weep!

SIB.

Why, dost thou think, poor mouse,

There are no sorrows but for childhood? none Beyond the schoolbook and the pedagogue?

HYL.

No mother: for my teacher says, that sorrow Haunts man's possessions all, except his grave. 
But when I weep, it is not long; for some one, That loves me, comes and comforts me.

SIB.

And who

Have $I$ to love me and to comfort me?

Poor prattling boy, thou art the only one Of the bright many that once thronged around me.

HYL.

Oh, but my father will come back!

SIB:

Forbid!

The gods

HYL.

Do you not love him, mother?

SIB.

Thou shouldst be whipped, thou magpie, for that question.

\section{HYL.}

I love him, mother, and I wish him back!

SIB.

And I, who love him with a flame that scorches The thought of self out of my heart, and limits Life to the measure of his dear affection, Wish him a thousand miles away from Thebes,Ay, a whole million, so I were but with him! Sirrah, dost thou not know, these knavish princes, These Spartan governors, would kill him? They 
Who have set a price upon his head, as on The meanest felon's, and decreed it death To any hind that in his cot receives him! No! the heavens witness, the mere thought that he, Moved by a rash and restless enterprise, Should approach Thebes, his most unhappy city, Affrights me. Better, better thus to know him, A houseless, friendless, childless, wifeless exile, Than see him dead!

\section{HYL.}

But, mother, if you love him, You will go to Athens; and, if you love me, You will take me with you:-I should be so happy!

SIB.

Happy indeed, thou prattler! But these Spartans,These bandogs that have driven out the shepherds, And turned upon the flock,-will have none happy Under their rule: no, they will not permit Even a poor child and mother to be happy.

HYL.

Are they all cruel, mother?

SIB.

All, my babe.

HYL.

I thought my lord Leontidas was not.

I think he loves me, mother! For, this morning, He said that I should be a soldier, with A horse and spear-Think of that, mother!-And He gave me this brave dagger.- 
SIB.

Cast it away!

Put thy foot on it-Thy hand is yet too weak To use it on the giver!

HYL.

Mother?

SIB.

Again take gift from him.

Never

HYL.

But he spoke kindly.

I will not, mother.-

(Enter LEONTIDAS, behind.)

SIB.

Oh, I doubt not-Kindly!

His kindness is a dulcet death; and, like The ærial poison of a Siren's song,

Consumes the life, while it delights the sense.

$\mathrm{He}$ is thy father's bitterest enemy:

And thou must hate him,--ay, and pray the gods Knit thy young limbs into precocious strength, That thou may'st kill him.

\section{HYL.}

See, he smiles on us!

Kill him, mother?

SIB.

He! Where?-Ah!-Ye gods, Pity me and protect me!-This is well, And courteous, Polemarch! Does the tyranny 
Of your brave rule invade even the retirement Of a poor matron's household?

\section{LEON.}

When it hatches

Treason.-Dame, thou hast eloquence enough To turn the brains of half our citizens:

And what I have heard,-this musical adjuration, Which schools a child to be my enemy,Makes myself almost turn against myself, Leontidas detest Leontidas.My pretty young soldier, thou dost hate me now?

HYL.

Yes, I do hate thee.

\section{LEON.}

That's my little Greek.

And, for thy ready obedience to thy mother, Run to the court, and tell my Thracian groom He must let thee ride upon a tall, brave horse.

HYL.

Mother!

SIB.

Stir not. What, wilt thou let the honey Of a stranger's charming tongue befool thee ever?

\section{LEON.}

You are cruel, lady, - and not only to me Whose love should claim a lovelier recompense; To your fair self, whom 'tis unnatural 
For your fair self to wrong; but to this boy,

Whom you breed up to sorrow. You do condemn him To an anticipated, bloody death,

In the wild counsels you so rashly give him:

And teaching him thus to reject my favour, You rob him of a friend, who has the power To advance his fortunes.

SIB.

He shall have no advancement That thou canst give him, Polemarch. The son Of the most noble of Bœotian patriots Shall take no favours of Boetian tyrants.

\section{LEON.}

Now is this woman's prattle! Patriots, tyrants!As if the restless beggar that would mount, Yet cannot, were a nobler spirit than he That has clomb to power already!

SIB.

Mak'st thou the patriot So poor a thing? Is there no charm in virtue? No merit in the love of country?

\section{LEON.}
Ay:
But what have virtue and the love of country To do with patriots? Such things may have been, I' th' golden ages: but, now, they are the fictions, Wherewith th' ambitious fight their way to rule, And gull the freeborn slaves, their helpers-on. Virtue! Why virtue sits at home, apart 
From the great world, and its great villanies; And so doth freedom, which is only free

Where one sole man inhabits. The love of country Is but another name for love of that

Wherewith our country can enrich us, - wealth, Dignity, power,- the great divinities Which all men worship, and their only virtues. He that seeks these things is the patriot; And he that has them, and from the seeker keeps them, Tyrant-or so your patriot calls him.

SIB.

Alas!

If there be, then, no patriot, what is he That bleeds,- -nay, dies too,-for his country?

\section{LEON.}

A soldier,

That seeks the shortest road to power, and wins it By th' stupid shedding of some drops of blood; When great minds, greatly toiling, lose the prize: But yet not always wins it. Dost thou believe, Pelopidas, this manikin's sire,-my rival Of old, as now, - went forth to Mantinea To die for naught, - or for his country?

SIB.

His country,-for naught else!

For

LEON.

By Mercury,

He won the prize though! Scarce were his wounds well healed, 
When, rising from his sick-couch, he besought The people,- - the dear people,-in whose cause He had bled, for the great post of Bœotarch, (That office for which $I$ so long had toiled,) And the dear people gave it.

SIB.

And they never

Chose a more noble governor!

LEON.

Or lost

A more deserving one. From that moment, dame, I, a good patriot then, because in want Of all my foe had gained, swore, the dear people Should ne'er choose other governor;-and they shall not.

Ne'er shall my rival look again to mount, The chair of rule,- that chair which may be soon Higher and nobler,- a royal one, a throne Holding a king; the while my patriot rival Wanders, a baffled exile, through the world.

SIB.

Let it be so; be thou a king, Pelopidas A baffled exile: use but thy clemency,Discharge me from thy court, that I may follow My baffled exile in his wanderings.

\section{LEON.}

Thou shalt remain to share my fate,-to rail, To scold, to tyrannize, yet be my queen. 
SIB.

Never! Wert thou upon Olympus' top,

Throned in the state of Jove, and my poor husband

Chained, like a Helot, in his den below,

I should not choose, I could not choose, a moment

Betwixt the two,- the noblest and the basest.

\section{LEON.}

Hah! you are mad!

SIB.

Discharge me;

Give me to go: and, if 'twill move thee, know, I hate thee, tyrant,- -hate thee and despise thee!

\section{LEON.}

This is a frenzy in you. Though your boldness May trifle with my passion, yet beware My anger.

SIB.

Oh, my fate!

\section{LEON.}

A scorned affection

Withers at last to spiteful hate; a love, Leavened by constant insult, turns to gall. Love I have offered thee, such as would make thee The partner of a throne, mistress of power, And pomp, and pleasure, beyond all other women. Beware the change thine own wild words provoke, The fury that may crush thee,-ay, and all Thou lovest. 
HYL.

Mother!

SIB.

Manikin, how now?

No tears!-Why this is well!-rare gallantry!

New courtship! A weak, silly woman's whims,And perhaps coyness,-must be frighted from her! Thou scorn'st the soft and delicate persuasion, The tender and submissive oratory,

Which common lovers put upon their tongues;

Wouldst win by talking of thy hate and fury!My boy!-A rare, fine wooing! a new courtship!

LEON.

Lady, you jest?

SIB.

Oh, no-My boy, my boy!-

What, fright me into kindness!

LEON.

I pr'ythee, pardon

If my rough tyranny have drawn those tears, I pray you, pardon me. Your beauty drives me Into a mood of folly, which your sarcasms Sting into frenzy-Why do you stir me thus? Would you but smile a little, howe'er you railed, No slave should be more gentle and submissive.

\section{SIB.}

My boy, too! threat my boy? my innocent boy, That has not malice, yet, to harm a reptile. 


\section{LEON.}

These were vain words: and, well thou know'st, Sibylla,

Thy favour is a refuge and protection

Safe as an altar.

$$
\begin{aligned}
& \text { SIB. (To Hylas.) } \\
& \text { Sirrah, will you go study? }
\end{aligned}
$$

\section{LEON.}

Stay, lady.

SIB.

Oh, my lord, I thought you were bent

To win my kindness?

\section{LEON.}

With my best of service!

SIB.

To-night I would be with my child alone.Oh, my good lord, you know not woman's nature:

Our humours are the ladders to our heart; And he who would climb into its richest seats, Must step them gently, one by one.

\section{LEON .}

I'll please you; And dream I am one step nearer to your love.

(Exit.)

SIB.

Slave! - that my fate should bind me to dissemble A moment with a wretch so scorned as thou!

(Exit with HyLAS.) 
SCENE II. A room in PHILIDAs's house. (Enter Philidas and a Slave.)

PHIL.

All finished? all complete? the tables spread With viands costly and luxurious?

The couches cushioned with rich robes? the torches

Lighted? ('Tis brave!) the dancers and musicians Already come? and (hark ye, did ye mark?)

Close barred the casements, - to shut out the cries Of the disorderly base rabble? (Alack!

And to shut in some others!)

(Enter a second Slave.)

PHIL.

What! how now?

Come they, my princely masters and my guests?

\section{D SLAVE}

A peasant-and a huntsman, as he says, With a present of game, a fat hind and wild boarCraves to speak with you.

PHIL.

Out upon the boor!

Take him among you, and let him feed and sleep. I'll see him on the morrow. (Exit 2D SLAVE.) Where bides my nephew, My petulant, wilful kinsman?

\section{IST SLAVE}

Good my master, He hath ta'en horse, and ridden I know not whither. 
PHIL.

What! i' the storm? The madcap!-Pray the gods, He quickly meet them!-Why, this feast would feed Five hundred starving Thebans!-

(Re-enter 2D SLAVE.)

PHIL.

What, again?

2D SLAVE

The huntsman, may it please you,-

PHIL.

Out, the knave!

What want I with huntsmen?-

\section{D SLAVE}

Twelve hounds-

Says he has brought with him

PHIL.

Twelve villains! What would I with hounds?

(Aside.) Unless they were bloodhounds of a kind I dream of!

$$
\text { 2D SLAVE }
$$

He says, you will like these, master; for they are Of the true old Cadmean breed.

PHIL.

$$
\text { Hah! what? }
$$

Of the Cadmean breed? Twelve hounds!

$$
\text { 2D SLAVE }
$$

And trained

To hunt all manner of beasts. 
PHIL.

Bring him before me.

(Exit 2D SLAVE.)

PHIL.

Get you to the kitchen, sirrah, and see the dancers And harpers well bestowed. (Exit IST SLAVE.) Twelve hounds? Twelve hounds?

Of the Cadmean stock, - and trained to hunt

All manner of beasts! That has a meaning in it.-

(Enter PELopIDAs, disguised as before, with 2D SLAVE.)

\section{PHIL.}

Get you away; seek out my nephew Melon:

I have occasion for him. (Exit 2D SLAVE.)-Are you $\operatorname{mad}$ ?

Speak not above your breath. You have enter'd into The tiger's den; and the least syllable

Of your known voice would rouse more fear and fury Than a loud trumpet.

PELOP.

You have sharp eyes, Philidas?

PHIL.

For heaven's sake, go. A moment, and the tyrants, The Polemarchs, are with us.

\section{PELOP.}

Am not I

Also a guest? I come to sup with them,I and some others that they wot not of.

I pray you, moderate your fears: if you Stand safely in their favours, all is well. 
PHIL.

And if they see you?

\section{PELOP.}

Well, they will see naught

But a poor abject clod, a grovelling peasant.

They see not with your eyes: and I have had proof, Even at your doors, that my disguise conceals me.

That varlet, Kalon, he that has dwelt years

Among my household,- -he that let me in,

And spake with me,--he did not know me. Wherefore

Content ye; and advise me why ye sent not An answer to my messenger?

PHIL.

A messenger!

PELOP.

That moment I a hint received of this

Your festival, I sent ye word again

I should be with you. The knave was trusty, too:

This must be looked to.

PHIL.

But your twelve hounds,- - twelve friends!

Brought ye no more?

PELOP.

They have all sworn to die,

Or free their country, - and they are enough. Send for them at the Delian Gate: they lie Among the rocks beneath the wall. 
PHIL.

\section{The Delian?}

'Twas at th' Athenian port I looked to find you; And there my nephew waits.

\section{PELOP.}

Well, let him seek them

At the Delian Gate, where they lie hid: the others, Four hundred armed and desperate men are posted, (Or will be, soon), upon the Hill of Fortune.

\section{PHIL.}

It shall be done.-Perhaps, I could explain This luckless riddle of the messenger; But more delay were dangerous.

\section{PELOP.}

Are all things

Ready for midnight? In the street, I saw An old man perishing.-But 'tis no matterI thought me of my father!

\section{PHIL.}

These things are common.

\section{PELOP.}

Common! Yes,-common, where Tyranny hath planted

Her iron foot, and men permit to trample.

Alas, my Philidas! is not many unworthy The gift of freedom? I ask myself, Wherefore Is Thebes enslaved? There are a million men, 
Whom three men tread upon, rob, scourge, and murder,-

Do what they will with; and the million sit

Passive and cowering, as if 'twere gods that ruled them,

Not men,-infernal deities, whom neither

Fire nor steel can harm, not perishing creatures, Whom wasps might sting to death, or a mere schoolboy Slay with an arrow!

\section{PHIL.}

This is the stupor ever

Of bondage,-and ill the gods inflict, to punish Our wickedness, and, in that stupor only, Make it endurable or possible.

When heaven relents, the slumber ends, and men Start up their own avengers.-But now, I pray you, Bethink you of your danger, and depart.

Proceed to Charon's house; whereto your followers Shall be conducted.

\section{PELOP.}

To Charon's?

I have a thing here-I had thought to quell it;

But 'twill not.-Philidas!-

(Distant trumpets heard.)

\section{PHIL.}

Hark! the Polemarchs!

It is the trumpets of their guards, their Spartans!

PELOP.

Were they posted round your doors, I have a question, Which must be answered ere I leave you. 
PHIL.

Speak it.

PELOP.

I have a wife here, Philidas-What! shrink you?

The weakness of my nature, (I confess it:

My heart yearned like a girl's, when I bethought me Of her, long left deserted and in peril:) -

This weakness led me even to the door

Of my retired mansion; where, instead

Of an obscure and quiet solitude,

Such as should in a matron's house prevail,

I found the casements flashing with the light

Of flambeaux, and the halls reëchoing

With songs and revelry. It chilled my heart

What means it, Philidas?

PHIL.

Now shame upon you!

At such a time, to think of aught-

PELOP.

What means it, Philidas?

I say,

PHIL.

She hath invited friends. Our goodly dames

Fy, fy! perhaps

Must have their pleasures, even the while their hus-

bands

For them their rich lives are adventuring.

Pr'ythee, away now; and believe there's nothing

Evil in what thou'st seen. 


\section{PELOP.}

Believe! believe!

Nothing of evil! What thou knowest, Philidas, Though it were such an evil as would crush My heart to dust, and, for the laurel crown, Cover my head with shame, advise me of it. I will not stir, till thou hast told me all.

\section{PHIL.}

Repress your indignation then. Leontidas-

\section{PELOP.}

Leontidas!-I ask you of my wife, Of my Sibylla: speak to me of her.

PHIL.

First; then, your house, confiscate long ago, Is now the palace of Leontidas.

Well!

$$
\text { PELOP. }
$$

PHIL.

But you tremble?

PELOP.

The palace of Leontidas!

Go on-My house,

\section{PHIL.}

\section{Wherein}

His parasites, - those meaner ones that are From my high feast excluded,- - hold, perhaps, A revel of their own. 


\section{PELOP.}

Why, this is well, -

Well, well! but nothing of my wife! Has he,

This Thebes-born Spartan, the renegade, through whom

Sparta wrought out our ruin,--has he, then, Driven her forth,- - her and her little infant?

\section{PHIL.}

Not so: they are both still in the house,-detained, I am sure, unwilling.

\section{PELOP.}

\section{What! ha, ha! unwilling?}

Come, you mete out your niggard words as if They were life-drops from your heart.-They are enamoured!

Is it not so?-Women are fickle, Philidas!

PHIL.

This is the rumour.-

PELOP.

I will kill her, Philidas!

PHIL.

You rave! It is but rumour.

\section{PELOP.}

What! to fright me, With the palsying grasp of a domestic shame, From the bright pathway of eternal honour! 
PHIL.

I'll stake my life upon Sibylla's faith.

How can she hinder, if the Polemarch

Will choose to love, or to imprison her?

PELOP.

Love her! The gods confound him-I will grind him To atoms! tear him to pieces!

PHIL.

Why so thou shouldst. Such wrong should move thee faster in thy purpose, And stir thee onwards to a great revenge.

\section{PELOP.}

Revenge! Thou dost not know me, Philidas.

I would have sacrificed him to my country!

This sinks my virtue into personal fury, And makes the deed $m y$ vengeance, not my country's!

(Trumpets and music.)

\section{PHIL.}

I do beseech you, go-And yet, I fear,

It is too late.-Hark! they are at the gates!

Banish these angry wrinkles from your brow:

Assume humility; and, for the love

Of our brave friends, and for our country's weal, Which you have perilled by this rashness, speak not:

Of, if impelled by questioning, remember You are here a peasant,- - not Pelopidas.

Give me your spear; it will but wake suspicion.(He casts the spear away. Music.) 
(Enter ARCHIAS, and PHILIP, with other Guests, and Attendants.)

Health, honour, and welcome to my noble princes!

ARCH.

Our trusty Secretary!-(To PHILIP.) Well! I tell thee, These portents, that alarm the ignorant vulgar, Philosophers laugh at: tell them not to me.

PELOP.

(Apart to Philidas.) Philidas!

PHIL.

Peace!

PELOP.

Where didst thou hide my spear?

PHIL.

Where't shall not serve thy madness.-

\section{PHILIP}

Seen with mine own eyes?

But the vision

ARCH.

Why, it was a vision

Seen with thine eyes, then,- -but thine eyes turned inward

Upon thy frighted fancies. Fy! I tell thee, Thou wilt be laughed at. 
PHIL.

Peace! (Aloud.) What says my prince?

ARCH.

Our brother Philip hath been pleased to see, Just now, some terrible phantom at the doors Of that arch-knave, Pelopidas.

\section{PHILIP}

Deride me

Much as thou wilt; but, Archias, as I live, I tell thee truly: I was passing out, After some counsel with Leontidas; And saw, among the shadows of the portal, A gloomy shape that raised its hand, and pointed Unto the house with menacing gesture, andNay, I remember now, it did not speak:

But the light of the flambeaux falling on it, Revealed-

PELOP.

What?

PHILIP

Hah! What ho, the guard!

ARCH.

How now?

What is this fellow? And wherefore dost thou fear him?

PHIL.

(A part to Pelopidas.) Madman! 


\section{PHILIP}

By Jupiter, two stars, two comets, Are not more like than were that shape and this! Who art thou?

\section{PELOP.}

A poor peasant, good my prince,-

A wolf hunter. I pray your highness pardon, If that my ignorant folly did alarm you.

\section{PHILIP}

Fellow, it was not thou. This thing I saw, Though like thyself attired, did bear it nobly: Ay! and methought its frowning face resembled The aspect of Pelopidas!

\section{PELOP.}

Oh, my lord,

I am no traitor; yet, forsooth, 'twas I.

I did but wonder, when I thought how much The gods did smile on some, who thus reposed In golden palaces; while others, wretches Like me, were shivering in the houseless air, And hissed at by their fates, as by the tempests.

\section{PHILIP}

But thou didst frown!

\section{PELOP.}

Ay, sooth,- - and cursed too,To think how, like a cur, they drove me forth, When I did beg to warm me at their fires, And pray for bread of their rough menials. 


\section{DRAMATIC WORKS OF ROBERT BIRD}

\section{Alack! I did forget that him the gods}

Frown on, man frowns on too, adding his scorn

To the sharp scourges of adversity;

I did forget I was a poor, base hind,

And they too rich and great to pity me.

Yes, I did curse them!

\section{ARCH.}

And for that, thou knave, Thou shouldst be punished. Learn to be humble, sirrah.-

Whence comes this caitiff? and what doth he here?

\section{PHIL.}

A hunter from the mountains, good my prince,-

A poor rude fellow, that would take service with me, Being weary of his calling.

ARCH.

Let him be looked to;Dost thou observe?-For, though so rude and brutish In his appearance, there's a dangerous cunning Lurks in his eye, and mutters on his tongue: Even peasants, sometimes, play the patriot! Let him be looked to: I, upon the morrow, Will sound him further. But no more business To-night, which must be all given up to pleasure. So end all visions, Philip! Come,- - to the banquet! (Exeunt, with music, all but Philidas and Pelopidas.)

\section{PELOP.}

(Gazing after Archias.) To-morrow, fool! there's not a cur in Thebes

Shall think thy bones too noble to be gnawn!- 
Peace, Philidas! thou wilt call me rash and mad:

I could not stand before them face to face, These things of clay that sit i' th' seats of Heaven, Holding the reins of rule, yet, all the while, Base as the things they rule,- - these pitiful wretches (For, sure, they are pitiful,) that hold in bonds A gallant people,- - a warlike, freeborn people,Without being moved to passion. And such men All Thebes cries Masters to! Well, be it so: There are Thebans yet to bring them to the reckoning!

PHIL.

I pray you now,

Go, and be wiser; and, as you shall answer For all the lives that hang upon your prudence, Go not near your own house.

PELOP.

What, Philidas!

Thou should'st not then have said it!-But, I pr'ythee, See that my friends be housed with noble Charon. And, if thou canst, ply well the guards with wine: Let them drink deep.

PHIL.

It shall be done, and well too.

I have hopes they will prefer my nephew Melon To be the Captain of the Guard. And, hearken:They have commanded I should grace the feast With guests ne'er seen at such a festival,The loveliest and most noble maids of Thebes; Whom Archias, too, would have (as if their presence Were not enough of shame,) come garbed for pleasure In the Bacchante robe and coronal. 
226 DRAMATIC WORKS OF ROBERT BIRD

\section{PELOP.}

Enough; their own device instructs us. This will pass us

Through their besotted warders.-But beneath Each flowery crown shall lurk a stinging adder, Under each robe a death.-Away, and lull them. Act thy part well, and think of us at midnight!

(Exeunt.)

END OF ACT II. 


\section{ACT III}

SCENE I. A room in Charon's house. (Enter Charon, Melon, Damoclides, and the other exiles.)

\section{CHARON}

Enter, brave friends! It warms my heart to see you, To know, in these base days of bonds, there are Some Greeks yet that will sell themselves to death, Rather than slavery. But where, I pray you, Is our heart's hope, Pelopidas?

DAM.

$$
\text { Nay, where? }
$$

Sought he not you? He did advance before us, To try the perilous entrance of the city.

\section{LAON}

Perhaps with Philidas?

CHAR.

Nay, the gods forbid!

He haps there on the tyrants.

\section{LAON}

Would my dagger

Were at the throat o' th' messenger, that brought us 
To this confusion!-Where, then, should he be?

It may be, with Sibylla?

MEL.

That were madder

Than being with mine uncle: he there falls

Into the clutches of Leontidas.

\section{LAON}

By heaven! he bad us, each man on his truth, Look not on wife or child, till he could bear them The gift of freedom. 'Twas a wise man's charge. Yet, well we know, his strong heart beats the woman When one salutes it with Sibylla's name.

CHAR.

It is not possible he who saw the pit, And warned his friends, should be the first to fall. This were so rash a step, so full of peril To our great enterprise, so full of shame, too, To him that takes it, and of wrong to those That are leagued with him-no! I'll ne'er believe it. It were, indeed, a madness: for Leontidas,

Our forsworn countryman, has craft and wit Beyond his colleagues: to come near him were To be discovered and so ruined. Tarry Awhile; and all will yet go well. Thou, Melon, Away to Philidas, and him acquaint With this our misadventure. As for us, Though leaderless, yet are we strong enough To strike the blow we aim at.-Friends, go in, And fit yourselves with weapons and disguises.

(Exeunt.) 
SCENE II. A banquetting room in Philidas's house. ARCHIAS, PhILIDAs, and the Guests discovered on couches, with tables set out, attended. The storm, at intervals, heard without.

\section{ARCH.}

Raves the storm yet? Why then, 'tis like, those fair ones

Will never grace the banquet?

PHIL.

On my head be it:

Nor frost nor storm shall keep them from the board, When the hour comes for their appointed visit. Will you have music now? Our gentle harpers, Lamprus and Dionysius, still can draw A smile of rapture out of melancholy; And the soft flutings of Olympiodorus Breathe like sweet zephyrs through Elysium.

Or, lo, these playing, an invisible choir, The nimble dancers shall amuse my prince,Those airy spirits, who, in grace, outvie The wanton Dryads, whom they imitate, Skipping, as eve and Dian call them up, Through the green alleys of a haunted wood.

(Enter, as Wood-nymphs, Female Dancers, who dance to music of flutes and other instruments.)

ARCH.

Such were the Nymphs o' th' Wood; of whom 'twas fabled

Their beauty struck the wandering gazer mad. Give me, my Philidas, for nymphs so baleful, 
Those human Dryads, daughters of men, whose charms

Delight, not madden,-inflame the brain to joy,

Not fire to frenzy.-

(Here a great shout is heard from the street, which arrests the dance and music.)

ARCH.

Hark! what sound is that? (Enter MELON.)

What means this clamour?

\section{MEL.}

Good my prince, a folly

Of the poor rabble,- - the grim and hungry rogues, That pause i' th' street to catch the sounds of revel, And the cold bits thrown to them.

ARCH.

Of the great outcry?

But the cause

MEL.

'Twas the sudden parting Of the dark clouds; through which, all beauteously, Shone the bright stars that Thebans love the best, The Orionides.

ARCH.

What were they?

PHIL.

Two virgins

Of the old ages, good my prince,- - the daughters Of our great Titan ancestor, Orion,- 
Who, when a pestilence afflicted Thebes,

And naught but such high sacrifice could stay it,

Gave up their lives to save their countrymen.

For this brave act of piety, the gods

Set them in heaven, star-throned; where now they shine,

Orbs of our Theban destinies.

ARCH.

It is

Another omen then! and the curs dream

They see the genius of their freedom shining! This were rare food for Philip; who is, already, By signs and portents, set beside himself.-

(Enter PHILIP.)

\section{PHILIP}

Break up the feast! give o'er these follies, Archias;Danger's afoot.

ARCH.

Said I not so!-A plot

Hatched in the skies, by th' stars? Why this, already, We have discovered. Fy, man! Sit you down, Enjoy the feast, and think no more of portents.

\section{PHILIP}

'Tis not of portents, Archias, that I speak. Strangers are in the city!

ARCH.

Well! and when

Are strangers not? Shall such things terrify thee? 


\section{PHILIP}

They came by night, and through a gate unguarded:

Is not that worth inquiry?

ARCH.

Well, to-morrow

It shall be look'd to.-And, that the gates may be No longer left unguarded, we will place

A trustier captain o'er the watch. Thou, Melon, (For thus we show our love for thy good kinsman,) Art now our officer.

(He gives a sword to MELON, who kneels to receive it.) Punish those knaves

That have their posts deserted, and their places Supply with better men.

MEL.

$$
\text { I am for ever }
$$

Your highness' slave!

(Exit.)

\section{PHILIP}

Already entered?

$$
\text { But, Archias,-these men }
$$

\section{ARCH.}

Would thou couldst sip a little Of hellebore, to lull thy fearful spirit, Ever in tumult! Wilt thou mar the feast?

Poison our joys? recall us back to toil,To the dry drudgery of magistracy?

Because, forsooth, strangers are in the city!Merchants, perhaps, that travel with their wares; Or trafficking boors that come betimes to market; Or thieves, slipped in to rob the citizens. 
PHILIP

Such are not these. A curious fellow saw them Received in Charon's house.

ARCH.

I see, thou hast sworn

To drive me from peace! In Charon's house?What think'st thou, Philidas?

PHIL.

Think! $-I$ think, my prince?

No evil, I hope! Methinks, no dangerous persons Durst visit Charon.

ARCH.

Why, so think I! But let him

Be sent for, to explain their character,If Philip will have it so! Or rather, Philip, Give this night up to pleasure; and let business Wait for the morrow.

\section{PHILIP}

It shall be looked to now!

What if these men should prove conspirators?

You'll thank me for my terrors.

(Exit.)

PHIL.

(Aside.) Frowning Fates!

Avert your visages from Thebes; or turn them Upon her tyrants only!

ARCH.

Philidas-

In faith, thou look'st as much disturbed as Philip! 


\section{PHIL.}

Alas, my prince! my fear is for your pleasures, Thus broken in upon by things of naught.I do not think these men worth apprehension.

ARCH.

Nor I, good sooth.-But seest thou, Philidas?

This is a circumstance of which thy wit May make a weapon 'gainst an enemy. Stranger by Charon harboured!-Dost thou mark?

PHIL.

It shall not be forgotten.

\section{ARCH.}

Why, then, again

We'll turn to pleasure. Let the tempest rage, Let omens thicken, and your Theban stars Pierce through the rack: confiding in that planet Which rules our own high, happy destinies From this hour forth, we'll think of naught but pleasure.

(He takes his place at the table; the music and dance are resumed; and the scene closes.)

SCENE III. A room in the house of PELOPIDAS. (Enter LEONTIDAS, leading HyLAS, and followed by a Slave.)

\section{LEON.}

The banquet waits me? - It is naught, without Sibylla's presence!-But this beating storm, Grows it still on? will it not end to-night? 


\section{SLAVE}

I heard a man, who seemed a soothsayer, Say to a crowd, that stopped him in the street, The storm that lowered o'er Thebes would end at midnight.

\section{LEON.}

The frantic runagates! they have all day vexed The town with auguries, and dreadful hints Of blood and tumult. But enough of this.How fares old Hippoclus?

\section{SI.AVE}

Not well content

With his hard chains and dreary cell.-Good master, Methinks his gray hairs might be spared these hardships!

\section{LEON.}

What, sirrah!

Grow'st thou soft-hearted? In those iron bonds, And that dark prison, he remains a hostage, Until Pelopidas be cared for. Wherefore Look to him well, and think no more of pity.

(He waves the slave to retire. Exit Slave.)

Now, my young soldier, wilt thou go with me? Thou shalt see rare, brave sights; fine dancers,singers-

That shall, with pretty ballads, sing thee asleep,And princes, too-princes with golden crowns, And purple vests, - great princes, such as thou Shalt be, when thou'rt a man. 
236 DRAMATIC WORKS OF ROBERT BIRD

HYL.

As my great father?

Are they as great

LEON.

Greater.

HYL.

Did they win, then,

Their wounds at Mantinea? Or have they ever

Been brought off from the field upon their shields?

Never.

LEON.

HYL.

How are they great then?

LEON.

Of your father's country.

By being masters

\section{HYL.}

But my mother told me,

They did not win it fairly, in the fight,

As great men do. And, oh! she told me, too,

They ne'er had had it, but that a false traitor,

A scurvy wicked Theban, for the love

Of gold, betrayed it to them.

LEON.

By black Pluto,

She has the bitterest tongue!-Hark ye, rogue,-said she

This Theban, this scurvy, wicked fellow, - was $I$ ? 
HYL.

No: but she said, he was the only Theban Among the Polemarchs, the others being Perfidious Spartans.-I would I were a man, To swinge him!

LEON.

Sirrah?

HYL.

I'd do it,-and soundly, too.

Betray his own land unto foreigners!

Now I'll tell you what I think: My mother told me Of a bad man, Prometheus; who, for stealing The sun's light out of heaven, was chained on rocks, With hungry vultures tearing out his heart, For thirty long, long years. Well! such a man As sold his country, I would have him tied, With thirty thousand vultures round about him, Tearing his heart forever and forever.

\section{LEON.}

Thou fry of venom!

HYL.

What! you are not angry?

LEON.

Hark ye, ye goose,- -your mother told ye that?

HYL.

And if she did, she learned it of my father. 
LEON.

Come, you're a brave bird-Will you go with me?

HYL.

I'll ask my mother.

\section{LEON.}

Pho-think of the music!

I'll ask her.-

$$
\text { HYL. }
$$

\section{LEON.}

And the pictures!

H YL.

She'll let me go.

Oh! I hope

LEON.

The soldiers!

HYL.

Soldiers?

LEON.

Come.

HYL.

Soldiers with swords, and shields, and spears, and horses?

Oh, Jupiter! I'll go.

(Enter Sibylla.) 
SIB.

What, sirrah! where will you go?-

This is not well, Leontidas, thus tempting

My child with baubles, to seduce him from me.-

Come, malapert;- - to your bed.

\section{LEON.}

Alas, Sibylla,

Wilt thou let nothing love me that loves thee?

I did but tempt him to the festival;

Where I would tempt yourself. Relent, fair lady:

Unbend; throw by this frigid modesty;

And let me bid thee thither; where thy beauty

Shall bravelier shine than in this solitude.

Thou shalt, among the roses, wherewithal

We canopy our princes, sit the highest:

The proudest dames of Thebes shall do thee homage, And hail thee noblest, as they own thee fairest.

SIB.

This is to bid me sit among them, lord, Highest in shame! I thank thee; but I am A prisoner here.

\section{LEON.}

No prisoner, fair lady.

Now, by my life, thou shalt be free as air.

SIB.

Ay,-to go to the banquet! But where else?

LEON.

Where'er thou wilt. 


\title{
240 DRAMATIC WORKS OF ROBERT BIRD
}

SIB.

Pelopidas!

\author{
Why then, to Athens! to
}

\section{LEON.}

Pho! thou jeer'st me. Think no more Of the fall'n traitor; whom to mention stirs me To rage. By heaven, I hate thee, whensoe'er Thou mind'st me thou art wife of him I hate. His wife? His wife no more! I do divorce thee! (Have I not power that am a prince of Thebes?) Divorce thee from him, free thee from thy vows, To wed thee to myself.

\section{SIB.}

His wife till death!

Naught else divorces me.

\section{LEON.}

Well, death shall do it.

Thou speak'st his doom; and the next news from Athens

Shall bring thee word thou art a wife no longer. (Exit.)

\section{HYL.}

What said he, mother?

Shall my great father be his prisoner?

SIB.

His prisoner? No! If that their treacherous arts Can reach to Athens, they may murder him. The gods protect him ever!-

(Enter Pelopidas, as before.) 
SIB.

My women there, what ho!

What art thou?

PELOP.

The curs upon me?

Peace!-will you bring

HYL.

You shan't hurt my mother!

PELOP.

Well said, my Hector!-Now, by Mars, you stand Staring as at a Gorgon!

HYL.

'Tis my father!

Husband!-

SIB.

PELOP.

Stay, - let me look thee in the face!There's no dishonour there! by heaven, I read Naught, in thy visage, but my wife! my wife, True, fond, and honourable!

SIB.

Oh, Pelopidas,

Do I not dream now, in this rapture?

\section{PELOP.}

How the young fledgeling ruffled! Why, thou chick, Thou shalt be spurred and sworded,- -ay, and mounted, For a young war! 
SIB.

\section{Pelopidas!}

PELOP.

Does my rough casing scare ye?

Marry, how now?

SIB.

Fly, I pray you,

Out of this house. The Polemarch-

\section{PELOP.}

Leontidas is master here; and I,

I know it:

The sometime lord, have, like a prowling thief, Into his dwelling stolen. But, I pr'ythee, Tell me, how bears he? Does he-Curses on him! He dares-I'll tear him piecemeal!-he has dared To speak (the slave!) his fulsome passion to you? By Hercules!-But I scold.

SIB.

Oh, my loved husband, Why art thou not content to be known brave, But must be rash, too?

\section{PELOP.}

Why? Because, when nature

Like to a cunning statuary, cast me

I' th' mould of manhood, she forgot to make me

Of marble!-Why, thou hectoring rogue!-My heart here

Engendered vipers; and whene'er I thought 
Of thee, and these curst tyrants, they roused up, And stung me.-What, thou knave! I'll fling thee up, Till thou art lodged among the stars!-Sibylla, Look at him! By my faith, I think, in a year, I'll clap a helm upon his head, and send him To battle.

SIB.

Teach him to be wise, Pelopidas.

PELOP.

Wise! Now, by Jupiter, you do remind me Of weightier matters than mere fooling.-Tell me, How fares my father?

SIB.

Well: but-

PELOP.

Say no further:

I'll ask thee on the morrow.-But this business: Where is Leontidas?

SIB.

Gone forth but now,I think, to the banquet of the Secretary.

PELOP.

Good! Let them gather!-Did he anger thee? I know it! - he call'd thee goddess, and-such knavery!

SIB.

And ere he went, with insolent sueing, bade me To the feast with him. 


\section{DRAMATIC WORKS OF ROBERT BIRD}

PELOP.

Caitiff!-But I better

Think on it-He shall have his wish: you shall To the feast.

SIB.

My lord?

PELOP.

As I will.

To tread upon his neck!

SIB.

What do you mean? What will you do?

PELOP.

Kill him!

SIB.

Kill him!

PELOP.

Are you astonished? Fy! I have heard you boast, A Theban dame could bear as high a heart As ever a Spartan; and, by Jupiter, I thought so too. I held you strong of soul, Not apt to shake, like an Arcadian girl, And show a face of chalk at words of blood: And therefore did I tell you I would kill him,Him and his colleagues, the tyrant-tools of Sparta, The morrow's sun shall see them trampled clods, Corses cast out to feed Bœotian ravens. 
SIB.

Heaven help thee, then: and, for my sake, take care Of thy rich life.

\section{PELOP.}

Thou mean'st, the lives of those

That are leagued with me! But thou see'st my folly:

It had been better could I have forgot thee.

Well, I will steal out, like a thief, again.

Farewell, farewell-Hist!

\section{LEONTIDAS (Within.)}

Close the gates.

SIB.

It is Leontidas!

$\mathrm{O}$ heaven!

PELOP.

Begone, you rogue!

Hence,- to your bed, and sleep.

(Exit Hylas.)

And I am here

Without a weapon!-Contradict me, wife;

In whatsoe'er I speak, do thou gainsay me:

Do this, (I'll play the faithless emissary:)

Do it, and save your country,-do it bravely!

(Enter LeONTIDAs, with Guards.)

\section{LEON.}

Where is this skulking hind? this prowling thief, That steals i' the house of princes? 


\title{
PELOP.
}

Oh, my prince, pardon!

I-(Bid him hang me!) -am no thief.

SIB.

\author{
Save-hang him! \\ A thief and robber! \\ (The Guards seize upon Pelopidas.)
}

PELOP.

Out, alas, for pity!

Pardon me, mighty prince; I will confess!

LEON.

Confess what, fellow?

A foul conspiracy!

\section{PELOP.}

Oh, my great lord, treason,-

SIB.

Do not believe him.

LEON.

What treason? Speak,-confess! or in a mortar I'll have thee brayed alive. (The Guards here release PELOPIDAS.)

\section{PELOP.}

It shall not need:

Most merciful prince, I will confess it all.

Being a poor abject boor,-this matron's husband- 
SIB.

Most false! Believe him not.-

PELOP.

Pelopidas-

SIB.

False! false!

\author{
LEON. \\ What, knave?
}

PELÒP.

Did bribe me-

LEON.

What to do?

PELOP.

To carry, alack! a most vile, traitorous message

To his wife here.

And gold, too.

\author{
SIB. \\ 'Tis false!
}

LEON.

Thou shalt have pardon.-

PELOP.

Gold, my prince? Pelopidas

Did only promise silver. 
LEON.

Speak, what was't?

PELOP.

Tell her, ('twas thus he spake,) ere many days, I'll free her from her durance; and therefore bid her Be wise, be confident, be bold, fear nothing.

LEON.

Is this thy treason?

PELOP.

I fear to speak the worst:-

Tell her, I come (but when, he said not,) with An army of Athenians, that shall end The Theban Tyranny.

LEON.

Hah! Athenians?

PELOP.

I am sorry I did listen to the traitor.

But being a starving man, (alas! you know not How penury drives the wretched to misdeeds!) He bribed me thus to be his messenger.

Now, if your greatness will but pardon me, I'll-

SIB.

Do not listen to him; he deceives you. 


\section{LEON.}

Fair dame, forgive me--'Tis most manifest,A shallow plot. And you will still prefer This desperate fugitive, this schoolboy schemer, That can no plot frame, but must take his wife And servant to his counsels,- - him prefer To th' rival that his projects laugh to scorn, And, with a turn o' th' finger, counteracts them!Fellow, if I forgive thee, and employ thee, At such high wages, (See! 'tis gold; enough To make thee rich!) canst thou be true and honest?

PELOP.

True as my dog,- and honester!

LEON.

Away to Athens.

Then shalt thou

PELOP.

Blithely!

LEON.

And assure

Pelopidas, as from his wife, (you hear now?)

His friends in Thebes have raised a numerous party.-

PELOP.

Is't true though?

LEON.

Who await his coming,

To strike for freedom. Canst thou swear him this? 
PELOP.

Deeply; - and call the gods to witness it.

LEON.

Here's gold for thee.

PELOP.

O Jupiter! gold! gold!

I will away to horse right instantly.

LEON.

Stay: 'tis a bitter night: the storm will freeze thee.

PELOP.

I am too rich to fear't. To-night, my prince! I'll be in Athens at the sunrise.

\section{LEON.}

\section{Nay;}

At sunrise thou shalt go. To-night I'll lodge thee, And lodge thee well too, under mine own roof.

$$
\text { PELOP. (Aside.) }
$$

Infernal gods!

LEON.

What ails thee?

PELOP.

I did leave

In Athens, an old mother, that, but for me, Must perish,-miserably perish. Alas! For pity now, I pray your excellent highness,' Bid me set forth to-night. 


\section{LEON.}

Guards, take this fellow;

(The Guards seize Pelopidas again.)

Lodge him with the dotard: if he struggle, chain him. Knave! I suspect thee; and, methinks, thy visage I have seen before? What, sirrah?

\section{PELOP.}

Have ye no pity, and no piety?

$$
\text { Oh, ye gods! }
$$

\section{LEON.}

Take him away. Thou fool, that thought'st, with wit So poor and shallow, to deceive a prince! At sunrise, in the court, thy naked body Shall be the target of an hundred archers.

SIB.

My lord! my-

\section{PELOP.}

Woman!-Well, you'll find me honest, Though you suspect me.-Is the lady frighted?But my poor mother, whom I did desert,How she will curse me!

LEON.

Hence with him; confine him.

PELOP.

(A part to SibYLla, as he passes her.)

Fetch me a dagger! 


\section{LEON.}

Now, how poorly looks

The man thou lov'st, thus baffled, and exposed In all his arts and weakness!

SIB.

Pardon, prince,

For his poor messenger! (Aside.) Alas! - that I Could better dissemble!-Spare his life, I pray you: $\mathrm{He}$ is too mean and poor for your revenge. Pity him and discharge him.

LEON.

What! again

To aid my foe against me? I did purpose To slay the caitiff. But, if you will ransom So base a knave, or any hundred such, Grant me my boon, and you shall have your willCome to the banquet!

SIB.

Not to save a thousand, Though each one were Pelopidas!

\section{LEON.}

He dies then.

SIB.

Then let him die! Were it Pelopidas's self, Thus would himself command me: Death, with honour, Though on the block; not life, with infamy!

(Exeunt.) 


\section{ACT IV}

SCENE I. A room in CHARON's house. (Enter CHARON, with MELON, who is in armour, LAON, DAMOCLIDES, and the other Exiles.)

\section{LAON}

Inform us truly-was he with thine uncle?

Or has he been? or knows thine uncle of him?

MEL.

By Jove, I cannot say, nor could I learn:

I could not come to speech with Philidas.

For know, thou trembling-

\section{LAON}

Trembling? I can die

As boldly as my betters. But to be thus

Lopped of our head and right arm, in our leader, Is but exordium to our general ruin.

DAM.

It wants an hour to midnight.

LAON

We are bought and sold.

And ere then 
CHAR.

$$
\text { How, Laon! }
$$

LAON

Can ye not see it?

Are ye stones?

DAM.

What?

LAON

We have been decoyed

Into a net here, by this prating Vulcan;

Who hath toiled us, like his crafty prototype,

In our own loves, - our country being our mistress.

CHAR.

These are dark words.

DAM.

And slanderous!

\section{LAON}

How comes it,

He has parted from us, in our hour of peril?

We were wise, my masters! to intrust our lives

In the frail keeping of a man whose fate,

Up to this hour, so checkered and disastrous, Clambers to instant grandeur on our ruin.

CHAR.

He'll not betray us? 
DAM.

Not until the gods

Confound all good, and make the best the basest.

\section{LAON}

What matters whether he be false or true?

Folly may do the work of perfidy.

It is enough we are endangered by him.

And, on no groundless fear of his defection,

I counsel all, while still the road is open,

Retreat to Athens.

DAM.

And forever after,

While the world holds together, be recorded Its pitifull'st cravens!

MEL.

Right, right! Damoclides.

And, for the satisfaction of my friend here, This man who trembles not, yet counsels trembling, Know, you must stay, flight is impossible:

The gate you found unwatched, is now well manned By throngs of Spartan soldiers, for the which Thank me.

You?

CHAR.

MEL.

And the Polemarchs, - who have made me Their Captain of the Guard, I thank their worships! For, in the execution of mine office, 
(And to carve out an easier path for you,)

I from their sacred persons have withdrawn Half of their myrmidons.

\section{LAON}

We are lost then!

MEL.

Lost?

And still 'tis Laon says it! Why did ye bring This oracle among you?-Hark again!

Long did I counsel with my wit, to find What plausible circumstance would bear me out In further diminution of the guard; When, lo, Leontidas, upon some fear, (I know not what,) commands me to despatch A party to his house; and I have done it.

CHAR.

This were most fortunate, were our leader with us.

$$
\text { MEL. }
$$

It is so still. Our leader's but a man;

A great and valiant one, in truth; but not

So necessary to our enterprise,

We needs must drop it, when his arm is wanting.

Hark ye: the guards-(my knaves, that watch the princes,-)

Shall have their cups, and each a drugged cup, too.

Get ye your swords; and, at the gloom of midnight, Steal to mine uncle's house: you shall have entrance.

I like not this.

$$
\text { LAON }
$$

( $A$ knocking is heard.) 
CHAR.

Peace!

DAM.

Hark!

LAON

We are betrayed!

MESSENGER (Within.)

I' th' name of the Polemarchs, I bid ye open.

\section{LAON}

Lost! lost! discovered!

\section{MEL.}

Peace,-and get ye in.

This pigeon will ruin us.-If you are known, Knock 'em o' th' head, and raise the citizens. They must not see me here. Get in, I say; And, if you must, fight,- - and fight bravely. (Exit Melon. The others all retire, except Charon, who opens the door. Enter MESSENGER.)

CHAR.

What is the matter, that so noisily

You come into my dwelling?

MESS.

I am charged

To bid you, Charon, straight appear before The Polemarchs.

CHAR.

And wherefore? 
MESS.

You will hear it from themselves:

For the reason,

CHAR.

Presently, at the door,

I will attend you: I will but fetch my cloak, And follow you.

(Exit Messenger.)

What ho, my son! Lycophron!

My cloak here!-This disturbs me.-Friends, come forth!

(Re-enter Damoclides, LAON, and the other Exiles.)

Are we discover'd?

\section{DAM.}

CHAR.

I know not. I am bidden

Before the tyrants.

\section{LAON}

By heaven, thou wilt betray us!

DAM.

Laon, for shame!

(Enter the boy LyCOPHRON, with a cloak.)

CHAR.

I'll show thee how to punish

The deed of treachery thy fear imagines.

I have my son here-look! the only child

Of my life's autumn. Take him in your keeping:

And when you are certain (mark me, Laon, certain,)

I have betrayed you,-kill him. 
DAM.

$$
\text { Pardon us, - }
$$

Or rather him, good Charon; since no other Doubts your true faith and wisdom.

\section{CHAR.}

Rest content then.

Set sentinels at the windows and the doors;

And be no truer to yourselves than $I$ am.

(Exit.)

DAM.

Laon, this peevish and suspicious spirit Has wronged our friend.

\section{LAON}

Why have they sent for him?

DAM.

If from suspicion,-

\section{LAON}

If!-We were all wise

To trust our necks so madly! Do you not think, The Polemarchs would surely raise to honour That man of us who should the rest betray?

DAM.

Unto base honour. Fear'st thou such man among us?

LAON

I think that one should seek Pelopidas! 


\section{DAM.}

Where?

\section{LAON}

Where my fears report him, - with his wife. Will you trust me, in this office?

\section{DAM.}

Trust you, Laon!

We are brothers in this enterprise; and each Finds in his fellow but a second self.I think, 'tis needless.

\section{LAON}

I will find you out

What base we stand on, which now shakes beneath us, As if 'twould ope and swallow us. This doubt Is worse than danger. I will hence, and fathom The riddle of our leader's vanishing.

\section{DAM.}

Perhaps he is tempting forth the citizens, $T$ ' invest the citadel: and one imprudence Might blast the coming fruit of all his labour. What if yourself, by some mischance, should stumble Upon an enemy?

LAON

You do not fear me?

DAM.

Fear you? Most surely no. 
LAON

Then I'll attempt it.

And, if you doubt me, I will swear-

\section{DAM.}

You have,

Already, your spirit pledged to the black Furies, If you should fail us in one article

Of our most solemn covenant. Be but

Discreet in what you do; we ask no further.

(Exeunt.)

SCENE II. The banquetting-rooms in PHILIDAs's house seen behind, with tables and guests; in front, an Ante-room, into which Enter ARCHIAS and PHILIP, attended by PHILIDAS.

ARCH.

Thou wert fitter for an augur than a prince,A priest of melancholy Proserpine,-

A servitor of the dim Trophonian cave, Where all is night, and mystery, and horror. How wretched he whom Fear thus dominates, Scourging with every fancy; who sees a spectre In every shadow of the night, or hears it Wailing on every wind.

\section{PHILIP}

More wretched he,

Buried in pleasure and security, Who shuts his sense 'gainst every warning token, Wherein the wise may read their destiny. I tell thee, Archias, this drowsy ease 
Suits not the time, when dangers lower around us.

The air is big with them, the city alive

With hints, and rumours, and whispering expectation,

That prates of mischief and conspiracy.

What if these knaves be exiles? Are we ready

To meet their rancorous onset? Are we safe

Even here, so fondly sitting at the feast?

Our new-made officer, upon some whim,

Has half,-nay, more than half,-the guard withdrawn.

PHIL.

Please you, my prince, 'twas done upon no whim. My lord so willed it, and I did advise it.

ARCH.

In faith, 'twas done to please thyself. I sent them To guard the gates. And hereby, if an exile (As you will have it so,) have crept upon us, We have him safe.

\section{PHILIP}

And then, another party

Leontidas hath sent for to his house.

Is there no fear in that? Leontidas

Was ever shrewd and wary.

ARCH.

Let him fear,-

And all that will: these bugbears fright not us, Nor shall they scowl down our festivities.

Come these Bacchantes yet? In sooth, my brother, They'll toy these horrible fancies from thy brain.

(Enter the Messenger and CHARON: the former retires.) 
And here, to chase the frightfullest away

Comes our good, honest, faithful Charon.

\section{PHILIP}

Charon!

How haps it, that suspicious men are seen Received into your dwelling?

\section{PHIL.}

Do you hear?

High highness asks you, wherefore do you harbour Strangers; whom, as we fear-

\section{PHILIP}

Peace; let him answer.-

Upon my life, he changes countenance!

\section{CHAR.}

Alas! I hope there was naught evil in them!

ARCH.

'Tis true, then? Why, there may be evil enough.

Who and what are they?

\section{CHAR.}

May it please my prince,

Poor hinds returned from hunting; who besought me To buy their fortune of the day, - a boar And hart o' th' mountains.

\section{ARCH. (To PhILIP.)}

Never tell me more

Of your redoubted strangers! 
CHAR.

Their wild quarries

I satisfied them for, and so discharged them:Mere boors, my prince.

\section{ARCH. (To PhILIDAS.)}

Of the same batch, I doubt me,

As our rough captive?

ChaR. (A part to PHIL.)

Captive?

PHIL. (A part to ChAR.)

The good gods lull them to security.

Peace!-So let

Are you ready?-Speak not! At the midnight come.

\section{CHAR.}

If still my lords suspect these men of evil,

I'll have them sought for, and examined.

\section{PHILIP}

Do so:

There may be more in them than meets the eye:

Let them be found.-But, stay-Leontidas!

\section{LEON. \\ (Enter LEONTIDAS.)}

Feast on, feast on; I have good mirth for you!

ARCH.

Why, that is better far than hints and riddles, And words of peril, that disturb our revels. 
LEON.

Yet there is peril in 't, though peril over.

I have now in my hands a dangerous fellow,-

A boor, a huntsman-

ARCH.

Now, by Hercules!

Is the world filled with huntsmen?

\section{PHILIP}

Treason! treason!

\section{LEON.}

Why, what's the matter, that the word disturbs you? A boor, a huntsman-

What more, indeed?

\section{PHIL.}

Ay! a boor, a huntsman!

LEON.

A secret emissary

O' th' plotting exiles, whom I found conferring With the wife of Pelopidas.

\section{PHIL. (Aside.)}

Oh, miserable!

\section{PHILIP}

A figure tall and sinewy?

LEON.

$$
\text { Ay! }
$$


ARCH.

And prating villain?
A cunning

\section{LEON.}

What! have you seen him?

ARCH.

Philidas, man! has he escaped you?

\section{Hark ye,}

\section{LEON.}

\section{Hah!}

Why this is rare! What! a base peasant stalk, From house to house, among the Polemarchs!

\section{PHILIP}

Is he secured?

\section{LEON.}

As closely as stone walls, Bolts, and armed guards, can bind him.

$$
\text { PHIL. (Aside.) }
$$

Rash and wretched!

\section{PHILIP}

Now can I breathe again, and speak my thought. This man, whom, like a phantom, first I saw Under the shadowy arch of his own portal-

\section{LEON.}

What say'st thou? hah! 


\section{PHILIP}

By all the deities,

When, in the gloom, I saw him, (better noting His angry brow than coarse attire,) I thought him The spectre of a dead Pelopidas!

LEON.

What ho! more guards! give me more guards! I, too, Saw somewhat in his face that woke me up Strange recollections. And the anxious fears Of his wife too! By Pluto, it is he! And in our power!

ARCH.

Thou canst not think it he?

Hot as he is, this were too mad a feat; And ye are mad to think it.

LEON.

Give me guards!

I'll prove it soon. Philidas! Secretary!

Send me an officer to the citadel;

Bring me an hundred men: I'll have no fewer To stand in watch upon the prisoner.

Send for them straight.

(Exit.)

\section{PHILIP}

Where went those huntsmen, Charon? They must be found: I do distrust them still.

\section{ARCH.}

Must thou still rave? Do traitors bring such traffic,Wild-boars and mountain-harts? 
PHILIP

Till I have found them.

\section{ARCH.}

Now these lunatics

Are gone, we shall have peace again. But, Philidas, How came this man with you?

\section{PHIL.}

Upon pretext

Of seeking service-A poor mountaineer, As I must needs still think him: perhaps a spy, Sent by the enemy; but, sure, no exile, Nor man of name or note. For his escape, I do confess, but lightly fearing him, I guarded him but lightly.

\section{ARCH.}

Well, at least,

He is safe again. If there be evil in him, We soon shall know it. And, therefore, we'll forget The rude mishaps, that have our joys disturbed; And once more to the broken feast again.

(He retires into the banquetting-room.)

\section{PHIL. ( $A$ part to CHARON.)}

No words!

His madness has undone us. We must strike Instantly now, or die. Get cloaks and garlands, To pass the guards-We may be yet successful. (Exit, Charon; Philidas retires into the banquettingroom, and the scene closes.) 
SCENE III. A sirong room in PELOPIDAs's house. (Enter from a vault, PELOPIDAS, leading HIPPOCLUS, the latter in chains.)

\section{PELOP.}

Gently; take heed of this same broken step. The air is freer here. What! did they keep thee In that damp vault,-an old man such as thou? And chained too?

HIPP.

Good young man, who art thou, That speak'st such kindness to old Hippoclus?

PELOP.

I? who am I? These hardships-But no matter.

I am a prisoner, like yourself; and, looking For ways of flight, I drew the bolt which led me Into your dungeon.

HIPP.

Then you are a foeman

O' th' Polemarchs? a Theban patriot.

PELOP.

Do you not know me? Look!-here, in the light!

HIPP.

Alas, mine eyes are sightless.

PELOP.

Hah! 


\section{RIPP.}

Imprisonment

I' th' sickly cell, and failing age, and sorrow-

\section{PELOP.}

Gods! and he still did chain you?-O my father!

HIPP.

Methinks thy voice is like my son's: but heYes! he was banished by the Polemarchs.

PELOP.

Father! my father! will you not now know me?

HIPP.

Art thou Pelopidas, and a prisoner?

Thy tones are his: but the first vow I taught him, (Bravely he swore it, too,) was ne'er to yield him,To die $i$ ' th' field, ne'er live a prisoner!

PELOP.

I swore ' $t$, and I have broke it.-But they took me Unarmed.

HIPP.

Away, false slave! thou art not he.

Pelopidas among his foes unarmed!

PELOP.

Father!

HIPP.

Unarmed? Thou slander'st him. My son Sleeps with a sharpened dagger in his hand, 
Eats with it in the dish, and, at the altar, Prays with it in his bosom,- -and so will do, Long as a tyrant lives in Thebes.

\section{PELOP.}

My heart!

$$
\text { You wring }
$$

HIPP.

If thou beest, then, Pelopidas, how art thou In Thebes a prisoner?

\section{PELOP.}

I came to free it.

HIPP.

And art a captive? Go! Pelopidas

Was not more valiant-souled than he was wise.

\section{PELOP.}

Still am I he; and can such proofs discover As will your doubtings change to curses. I Am he, whom, foolishly, my fellow patriots (The only Thebans left to strike for Thebes,) Chose for their leader. And this post of honour, Diademed round with glory, like a boy, An idiot rustic, I have thrown away.

Nor that alone: I have destroyed my friends, And slain my country: they, upon the block, Whither myself have dragged them, bleed; and Thebes Robbed of her sons, remains a slave forever!

\section{HIPP.}

Art thou Pelopidas, and hast done this? 


\section{DRAMATIC WORKS OF ROBERT BIRD}

\section{PELOP.}

Curst be the tongue, that, with foul slander, stung me Into the madness that has done the wrong! Or curst the weakness of my own vile nature, Which thus could list to folly! For my wife, I have sold my country!

\section{HIPP.}

May the gods forgive you.

\section{PELOP.}

They will not,-cannot: when did Heaven e'er pardon The slayer of his country?--a traitor, whether The act be done in malice or in folly.Hark! 'twas a step!-Alas! no step,-no hope! Time flies-flies fast; and I am still a captive. Until this hour, I hoped some chance to free me; When I had well redeemed my forfeit honour. But it is midnight,- - midnight that should have seen me Hurling the tyrants from their thrones-

$$
\text { HIPP. }
$$

My jailer.

\section{PELOP.}

$\mathrm{Ha}$, ha! the gods be thanked!

HIPP.

What mean'st thou?

PELOP.

I'll slay him,- -snatch his weapons, and so cut My way to freedom!-Stand aside, and fear not.

(Enter SibyLla.) 
By heaven, Sibylla! -Didst thou bring the dagger? Quick! give it me-Why doest thou shake thus?Father!

I will retrieve mine honour.

SIB.

Stay!

PELOP.

This weapon

Makes me a god! ha, ha!-How got ye in?

SIB.

I bribed the sentinel.

PELOP.

Is there but one?

SIB.

But one man at the door; around the house, An hundred: you may see them from the window.

\section{PELOP.}

It matters not. Armed as I am in spirit To wipe dishonour from my front,- to save My friends,- to give my country liberty, An army should not stop me.-Father, I'll win Your blessing!

SIB.

Oh, my husband! my dear husband!

You will not out, against these odds? 
274 DRAMATIC WORKS OF ROBERT BIRD

PELOP.

Ay, truly,

I will! Farewell-I cannot talk with thee.

SIB.

Thou wilt be slain!

PELOP.

Fighting, not caged!

SIB.

Stay with me.

O heaven!

PELOP.

Peace!

SIB.

You are safe here. Wait until The guards are drawn off.

PELOP.

Look to my father there.

SIB.

Leontidas-

PELOP.

Hah!

SIB.

My women overheard him

Plotting to bear me to the citadel. 
PELOP.

Why dost thou prate thus? Lo! this steel is sharp!I'll be with thee anon.

\section{SIB.}

Well, heaven be with thee:

I will not stay thee. Go forth to the battle;

And if thou diest, die victorious.

Come back the conqueror, and thy country's saviour;

Or, like a hero, stretched upon thy shield,

Dead, yet unvanquished; and with joy I'll meet thee, As though thou camest a bridegroom to my arms;

Kiss thy cold lips, and think them lips of love;

Wipe thy red wounds, and call them nuptial jewels;

And strow thine honoured corse with flowers and wreaths

Rich as e'er decked a living conqueror-

With flowers, not tears!

\section{PELOP.}

There spoke my noble wife!

My Theban wife! Talk thus; and I will fight Till Sparta buckles!

SIB.

I'll wrap my cloak about thee:-

(Pelopidas throws off his cloak of skins, and puts on SibYLlA's mantle.)

SIB.

Perhaps, thus, thou may'st pass the sentinel, And reach the doors in safety. Then-and thenOh gods! 
PELOP.

And then, Sibylla,

Like dogs I'll scatter them! And so I bid you

Be not alarmed; fear naught-What, father!

Will you not know me now?

HIPP.

Thou art still my valiant son.

Go forth and prosper.

PELOP.

Remain with him.

Be of good heart, and-rear my boy to honour.

(Exit.)

HIPP.

What, is he gone? The great gods go with him!

SIB.

Hist!-If the guard should stop him? Hark! My father!

He will be slain!

HIPP.

Fear not.

SIB.

Hark! hark! I hear

The clash of armour!-From this window, I May see him-perish!

(She looks from the window.)

$\mathrm{Oh}$ ! ye pitying gods,

$\mathrm{He}$ is at the door!-They rush upon him!-See!

They strike him! Help him, Jupiter, with thunder! Ah! heaven!- 


\section{HIPP. \\ What see'st thou?}

SIB.

No!-it was a Spartan,

Struck to his feet!-Now! now! Pelopidas!

Strike!-strike again, and fly! $\mathrm{Ha}$, ha! by heaven,

$\mathrm{He}$ is clear! Fly swiftly! swiftly!-He is safe!

\section{HIPP.}

Daughter?

SIB.

Safe! safe!-he has fled; the darkness hides him!

Safe! he is safe, my father! the good gods

Have shielded him-We are not yet deserted!

(She kneels; HIPPOCLus extends his hands, as in prayer;

and the curtain falls upon the tableau.)

END OF ACT IV. 


\section{ACT V}

SCENE I. A room in Charon's house. (Enter DAMOCLIDES and other Exiles.)

\section{DAMOCLIDES}

Nor Laon nor Charon yet returned; Pelopidas Vanished away, unheard of; Melon absent;

Ourselves walled round with shadows none can pierce, And dangers, too: yet let not this disturb us.

Let no man's spirit fail. If we must fall, Yet we fall nobly; and hereafter, Thebes, By others freed, shall hold our memories dear, As her true sons and martyrs. But I hope A better fortune yet. Pelopidas, Though ta'en, and on the rack, could ne'er betray us; And Charon's faith is sure as any's. More I fear from Laon. Yet I would not wrong him. Pelopidas ever held him in regard.

\section{(Enter ChaRoN.)}

DAM.

What, Charon! safe and unsuspected are we?

\section{CHAR.}

Not safe, not unsuspected. Danger, growing, With every beat o' th' pulse, more imminent, Lowers around you. But you yet may save 
Yourselves, and Thebes too. Arm: and quickly, here, Put on these women's cloaks and coronals:

And then to the tyrants.

\section{DAM.}

Have you no words of him?

\section{But our chief? Pelopidas?}

\section{CHAR.}

Alas, too many!

Think not of him; or, if you do, forgive him. His rashness has undone him; and he is now I' th' hands o' th' Polemarchs.

DAM.

Ruined by rashness?
A prisoner!

CHAR.

In his own house.

$$
\text { Ay: a prisoner }
$$

DAM.

We did mistake him then;

Whom (on success of this our enterprise,)

We had hailed gladly supreme Bœotarch, Chief of all Thebes. What can we do without him?

CHAR.

Die, (if we must hope nothing,) die like freemen, With arms in hand; not tamely wait to perish Upon the headsman's block. 
DAM.

Why, let us on, then,

For death or victory,--for Pelopidas,

The loved of Thebes: we may, perhaps, yet save

His life, though never his honour-Hah!

(Enter Pelopidas, bloody.)

ALL

Pelopidas!

PELOP.

$\mathrm{Ha}$, ha! mine honour? thou liest, my Damoclides! $\mathrm{Ha}$, ha! mine honour? ne'er save mine honour? Look! Here is my weapon; there is blood upon it! The first libation-'Tis a Spartan's!

DAM.

What!

Is it a Polemarch's?

PELOP.

With this little weapon,

Cut I my way through twice an hundred men. Never mine honour? What, ha, ha! By Jove! I am with you, and will lead you where you will, With honour! Are you ready?-Oh, Damoclides, Can you forgive me?

DAM.

Speak of it no more:

You are still Pelopidas. 


\section{PELOP.}

I'll ne'er again

Find fault with him that's human; or look to have My friend a demigod! I have deceived you, Wronged you, almost betrayed you. Am I not punished

In the deep torments that afflict me? Charon, I left my father, blind and chained, exposed In a dungeon to the fury of his keepers: My wife, too, (have I not repaired my fault?) I left her to Leontidas! though nature Tugged at my heart, and filled it with distraction, I left her!-Come, I am ready: give me a sword.

\section{CHAR.}

A cloak, too, and a garland.

\section{PELOP.}

$$
\text { Ay, a garland.- }
$$

Myrtle leaves now, and laurel-crowns hereafter!

This cloak will serve me: 'twas put on my shoulders By the most noble wife of all the earth; And was the shield, wrapped round my arm, wherewith I stopped th' assaults of all the myrmidons.

Jove! but I had a time on' $t$ ! And they chased me, Like a hurt wolf, launching their darts and arrows, As 'twere another tempest, through the street.

A wolf I fled; and, like a wolf, I bore Their blood upon my fangs.- Hah! are you ready?I prattle like a girl!-All mantled?-Follow: And he that strikes more deeply than myself, Him, though a slave he were, I'll make my master! 
SCENE II. The Street. (Enter, on the one side, PyILIP, with Guards bearing torches; and with them LAON; on the other side, LEONTIDAS, also with Guards and lights. Shouts heard afar off.)

\section{LEON.}

What ho! Who are ye? Stand!

\section{PHILIP}

Brother, well met!

Leontidas?

LEON.

What mean these riotous cries?

Is it sedition? By heaven, I took ye for

A band of rebels that would block my way!

\section{PHILIP}

It is sedition. The town is all aflame.

The rumour of Pelopidas in the city

Has set all mad; and, Down, they cry aloud,

Down with the tyrants! Hence to the Citadel, If you would live.

LEON.

Why, let them roar their fill.

Without a leader-

\section{PHILIP}

Think not that. They have

Leaders enow, - ten banished men, from Athens. Look you, I have one here that hath surrendered, And all their scheme betrayed. Speak, slave; or ne'er Expect thy life and pardon. 


\title{
LAON
}

I will win them,

By speaking truth. Twelve men there were of us, Pelopidas our chief-

LEON.

'Tis true, then?-Let them howl:

We have him safe! and for the ten-

\section{PHILIP}

\section{Alas!}

There are four hundred more that follow them-

\section{Hah!}

\author{
LEON.
}

\section{PHILIP}

And, perhaps, already in the city. He hath told all.

\section{LEON.}

Four hundred exiles?

\section{PHILIP}

By a great legion of Athenians.

Backed

\section{LEON.}

Call all to arms! There is our safety; there Ho, to the Citadel! We can hold out against a hundred legions. Thither I'll follow, with my prisoner. But hold!-Knows Archias this? He must not perish,

No effort made to save him. What! my tablets! 
A word will rouse him from his revelry.

(He writes upon his tablets and gives them to a Soldier.) With thy best speed, bear these to Archias.

(Exit Soldier.)

On to the Citadel! Ere you shall have reached it, And called th' alarm, myself will be with you.

(Exeunt.)

SCENE III. The banquetting-room, as before. ARChIAs, Philidas, and Guests discovered. Soft music heard.

\section{ARCH.}

Fill wine again, to chase these fears away;

And think of naught but pleasure: fill, fill deep,

And, in libations to th' infernal gods,

To their dark realms devote our enemies.

By heaven, methinks no man hath smiled, since Philip

Breathed the curst name, Pelopidas, among us! Fill to the brim! Behold, I pour the offering, And thus devote him to the Furies-

(As ARCHIAs is about to pour the libation, the bowl falls to pieces in his hand. The Guests start up.)

ARCH.

Hah!

An omen!

\section{GUESTS}

ARCH.

What, again? Are ye such sheep! Hath Philip's folly so infected you? All things are portents to the ignorant; 
And only such should fear them. Fill again; (He takes another bowl; the Guests resume their seats.) And again pour the offering. Thus again To the infernal Orcus I devote him!The cup is whole, the omen fails us now! Speak to them, Philidas. Hast thou no wisdom, To drive these idle terrors from their breasts? Or hold'st thou, too, such faith in presages!

\section{PHIL.}

Not I, my prince. For who shall say, among Th' occurrents of affairs, which ones are they Wherein Heaven speaks? The vultures fly all day, Yet bear the fates not always on their wings; The thunders rattle when they will, without A god to wake them; dreams and visions move us, Stirred by no restless spirits but our own.

It is the error of our vanity,

To deem Heaven thus, in trifles, speaks to us.

ARCH.

Thou say'st the truth. Of omens, then, no more. Pleasure alone be theme of speech and thought. And him that frowns, looks sad, or frights the feast With word of care, I'll hold a knave and traitor. The cares of day enough the day employ: Pleasure to-night, and business for the morrow!Come our Bacchantes yet, my Philidas?

PHIL.

Anon, my prince.-

(Enter a Soldier of the Guard.)

What now? 
SOLD.

A messenger

From Iphias the Athenian,-these with speed:

(Gives a letter to ARCHIAs.)

Matters of weight and peril.

(Exit.)

\section{PHIL. (Aside.) \\ Lost! discovered!}

ARCH.

Business to-morrow!-Take it, Secretary.

If thou wilt read it, well: but tell not me

Of its contents.

\section{PHIL.}

'Tis nothing.-(Aside.) Foul divulgement!(Aloud) Suspicions of the exiles.

ARCH.

Now, by heaven,

I'll hear their name no more! Let them plot on, While we feast merrily. Fill up again.-

\section{(Re-enter the Soldier.)}

What, knave, again! What wilt thou?

SOLD.

Please you, my prince, a drunken fellow brought This letter for his excellence the Secretary.

ARCH.

Give it me, and begone. (Exit Soldier.) What, Philidas!

Our friends should have no secrets? 
PHIL.

None, your highness-

(Aside.) The letter of the Exiles! All is lost!

\section{ARCH.}

Faugh, how the cur hath thumbed it!-(To Philidas.)

\section{THE SECRETARY}

Some beggarly petition,

I doubt me! (He casts it away.) I did hope, a tender missive

Of some fair dame, to make a jest of!

$$
\text { PHIL. (Aside.) }
$$

I'll build an altar to thee (Music heard without.) Hark! they come!

The fair Bacchantes!

(Re-enter SOLDIER.)

On business of great moment.

SOLD.

A message from Leontidas, (He offers the tablets to ARCHIAS, who refuses them; and Philidas takes them.)

ARCH.

What, thou knave! At such a moment?-Business to-morrow! Hence All thought o' th' state,- of all but mirth and pleasure! 
(The Soldier retires. The great door is thrown open; and enter,- to music -in their cloaks and garlands, PELOPIDAs and the other Exiles, followed by Melon and CHARON, who secure the door. The Guests start up and clap their hands. ARCHIAs descends from his seat, and advances to meet them.)

Welcome, most welcome-Hah! what guests are these! (The Exiles throw off their cloaks, and draw their swords.)

PELOP.

Guests that ye looked not for. Down with the tyrants!

Down with their myrmidons!

(He attacks ARCHIAS; the others engage the Guests.)

ARCH.

A conspiracy!

Bring in the guards-What ho!-Defend me, Heaven!

\section{PELOP.}

Thou call'st in vain: the gods are deaf to tyrants!

(He kills ARCHIAS; the Guests are driven out.)

Die with thy minions!-Take them forth, and slay them.

Where is Leontidas? My steel is thirsty, But scorns the blood of bondmen. Where is he, The master tyrant?-Melon, see thou finish The work here. When 'tis done, set after me To mine own house. There is no true blow struck, Till struck i' th' bosom of Leontidas!

(Exeunt.) 
SCENE IV. The prison-room in PeLOPIDAs's house. (Enter LEONTIDAS, with several Soldiers of the Guard, one of them leading HYLAs.)

LEON.

If he be 'scaped-Yet, no! how could that be, Safe guarded thus?-( $A$ shout is heard. $)-$ Hark! how th' insurgent reptiles

Roar through the streets!-Bring forth the prisoner, The hind-

(Enter, from the vault, Sibylla; Hylas runs to her.) Sibylla here! Now by Ixion, And his infernal torment, this affrights me.Why art thou here?-Bring forth the prisoner.

\section{SIB.}

Speak'st thou of Hippoclus?

LEON.

Of a nobler captive.-

Thou bear'st it well! But now no more dissemblingI seek Pelopidas!-Dost thou hear me, villain?

The prisoner!

SIB.

He is beyond thy reach.

Seek in the vault for none but Hippoclus;

For none but he remains.

LEON.

Escaped!

SOLD.

I feared to tell your highness.

'Tis true: 
LEON.

Now may fire

Fall on the hand that freed him!

SIB.

'Twas $I$ that freed him.

Why, on mine then:

LEON.

Thou?

SIB.

I, Polemarch!

'Twas I that oped his prison door, and gave him The blade that won his freedom; I, even I, (The wretch thou thought'st fit only for dishonour,) That sent him forth to do the like for Thebes,To break her bonds, to arm her hands, to trample Her thrones and tyrants, till she is free as air,As free as he is!

\section{LEON.}

Thou wert a wife for Mars!

But triumph not too early. (To Soldier.) Rank the guards,

Straight, at the portal; and be ready all

To march to th' Citadel. (Exit Soldier.)-I make thee now

The last of love's persuasive invitations.

All is not won, nor is all lost; for, with

A Spartan garrison in the Citadel, And Sparta's self behind, you soon shall see me Master again of Thebes; her riotous people 
Chained in securer bondage; and their chiefs Again in exile. Think'st thou, thyself I'1l yield? Thou must go with me to the Citadel.

SIB.

Never, vain prince-Think not I fear thee now, Pelopidas hard by me! Save thyself.-(Another shout heard.)

Hear'st thou those cries, - the uproar of a nation Mad for the blood of its oppressors? Hence! I scorn and hate, but would not see thee slaughtered.

LEON.

Prattle these sarcasms in the CitadelThere is no time for trifling. What! I ask thee, Wilt thou go peacefully; or have my slaves, With base, defiling clutches, drag thee thither?

SIB.

I fear them not, nor thee. (She draws a dagger.) The hand that aided

Pelopidas, can help Sibylla too!

LEON.

The day of Amazons is past. (He seizes and disarms her.)-What ho!

Take the boy from her.

( $A$ soldier seizes HyLas.)

sIB. (To the Soldier.)

Caitiff! wilt thou harm him? 


\section{LEON.}

Take him along.

SIB.

Why take him, then-And see

Thou weep not, sirrah,- - not a tear, I bid thee,Not one, not one.-But still thou tak'st not me!

\section{LEON.}

Art thou so heartless to desert thy child?

SIB.

Art thou so base to steal him?

\section{LEON.}

Follow the path he treads.

'Tis to make thee

\section{SIB.}

\section{I would not follow}

Where thou shouldst lead him; though his tender arms Were knit among my heartstrings.-

(A'louder shout heard. SibYLla breaks from LEONTIDAS and clings to a pillar.)

Till my arms are hacked off.

Here I hold me,

\section{(Another shout.)}

LEON.

By heaven, the knaves Will be upon us! (He snatches up the boy.) What! thou driv'st me mad, And kill'st thy child-Come with me, or I slay him! 
SIB.

Monster! thou wouldst not hurt him?

LEON.

Come with me;

Or (by the gods, you know not how you stir me!)

I'll from the window hurl him-

SIB.

$\mathrm{Ah}$ !

LEON.

Upon the lances of the guard.

To perish

SIB.

Oh, man!-

No, no, not man; but fiend! most savage demon!-

Cast him forth, if thou wilt, upon the spears

Of thy base followers; or break and mangle His innocent limbs upon the flinty stones,

(Stones not so flinty as thy cruel heart;)

Dash out his brains before my eyes; thy dagger Strike through his neck and spot me with his blood; Do this,--do all: thou canst not move me yet One step more near dishonour.

LEON.

He dies then!

By Acheron,

SIB.

Spare him! Oh, thyself may'st soon

Crave the same mercy thou deny'st my boy.

Spare him, Leontidas, and thou shalt be spared. 
294 DRAMATIC WORKS OF ROBERT BIRD

Come with me.

\section{LEON.}

SIB.

Never!

(LEONTIDAS offers to cast the boy from the window.) $\mathrm{Oh}$, ye great gods, give me Such strength as wild wolves ye have armed withal. Hold, murderer, hold!

(She rushes against LEONTIDAS: a Soldier seizes her. Another Shout.)

LEON.

Out, viper's egg!

SIB.

Ah!一ah!

(She falls into a swoon: LEONTIDAS is about to throw the boy from the window: a great shout is heard: and enter PELOPIDAS, who snatches the boy from LEONTIDAS, and strikes the latter down. The Soldiers fly.)

\section{PEI.OP.}

What! kill the child? and not bethink thee how

The gods rain thunderbolts! Die, wretch! I strike thee

First for my bleeding country: (Stabs him.) 'tis appeased!

I strike now for Pelopidas!

(Kills him.)

(Enter Damoclides, Philidas, Charon, and Exiles; and one from the vault, leading HIPPOCLUS. PELOPIDAS raises SIBYLLA and gives her the boy.) 
Sibylla!

My dear boy, all unharmed!-Hail, friends! Thus falls

Another of your tyrants!

CHAR.

Hail thou! all hail

Pelopidas, our great Deliverer!

(Enter MELon.)

MEL.

Shout Victory all, and triumph,-Thebes is free! Fired by the name they love,-Pelopidas,The citizens have stormed the Citadel, And put the garrison to the sword; and with it, Philip the Polemarch; and Laon too, The traitor fugitive.

\section{PELOP.}

'Twas noble!-Father,

Have I not now redeemed mine honour?

(He kneels to HipPOCLus, who blesses him.)

HIPP.

The gods

Preserve you long Bœotia's champion.

\section{PHIL.}

'Tis triumph all! The exiles, in reserve Upon the Hill of Fortune, marching on, The townsmen aiding, have the gates o'ermastered; And all is ours. There's not a Spartan now Living in Thebes. 


\section{PELOP.}

Our liberty's accomplished!

Now let the world, that once derided, wonder;

Tyrants that scowl afar, look on and fear;

And the galled victims of their tyranny,-

The poor base fools that clank their chains and smile,

Thinking the sound is music,- - those who press them

Upon their breasts, and still have grace to groan;

Let them look on, leap up, and imitate;

Let them look on us, till the serpent's teeth

(Like those i' th' earth sown by our Ancestor,)

Root in their bosoms, and bring forth armed men, Striking for vengeance and for Liberty!

(Tableau and Curtain.)

END OF ACT V. 


\section{THE GLADIATOR}

The following text of The Gladiator is based on the best and fullest autograph manuscript among the Bird papers in the Library of the University of Pennsylvania. The collection contains two other manuscripts of the play, a complete rough draft in the author's hand, and a careful copy of the final draft in the handwriting of his wife. It seems that the MS. used for this text was submitted to Edwin Forrest, for whom it was written as a prize play, who suggested cuts and changes for the acting version. These alterations, marked with a pencil in the original, are enclosed in brackets of this form $<>$. Such changes in wording as apparently met with the author's approval have been followed for the most part without comment.

The Gladiator was completed in April, I831, Bird's second prize play accepted by Forrest. It was first produced at the Park Theater, New York, September 26, I831, and became at once one of the most successful plays on the American stage. After Forrest's death it was given by John McCullough, Robert Downing, and others with every mark of favor. 



\title{
THE GLADIATOR
}

\author{
A Tragedy \\ IN FIVE ACTS
}

PHILADELPHIA, APRIL, I 83I 


\section{THE GLADIATOR}

\section{Persons Represented}

Marcus Licinius Crassus, a Roman Prator.

Lucius Gellius, $a$ Consul.

SCROPHA; a Qucestor.

Jovius, a Centurion.

Mummius, lieutenant to CRAssus.

Batiatus Lentulus, a Capuan Lanista, or master of gladiators.

BRACCHIUS, a Roman Lanista.

Florus, son of B. Lentulus.

SPARTACUS, a Thracian,

PhASARIUS, his brother,

EnomaIrs, $a$ Gaul,

Gladiators.

CRIXUS, a German, and others,

$A$ boy, son of Spartacus.

Julia, niece of Crassus.

Senona, wife of Spartacus.

Citizens, soldiers, etc.

SCENE. Rome, and parts of Italy. Time, B.C. 73. 


\section{THE GLADIATOR}

\section{ACT I}

SCENE I. Rome. The Street before BraCchius's house. Enter Phasarius, AENOMAIIS, and other gladiators.

\section{PHASARIUS.}

There never was a properer moment. I look around me on the Roman flocks, that are deserted by their watchdogs and shepherds, and my fingers itch to be at their throats. Rome has sent forth her generals to conquer the world, and left nothing but her name for the protection of her citizens. Where now is that warlike, arrogant, and envious coxcomb, Pompey? Quarrelling,-he and that old brawler, Metellus,-in Spain, with the rebel, Sertorius: Lucullus, the Spoiler? Chasing the braggart, Mithridates, over his Pontic mountains: and Marcus, his brother? Killing the rest of my countrymen, the furies speed him! That restless boy, young Cæsar? Among the islands, crucifying the pirates. Marius dead, Sylla rotting.There is not a man in Rome, that Rome could now look to for service.

ANO.

The prætor, Crassus. 


\section{PHAS.}

The miserable rich man, the patrician monger, that, by traffic in human flesh, has turned a patrimony of an hundred talents into an hundred thousand! If there be any virtue in the love of wealth, then is the prætor a most virtuous man; for he loves it better than he loves the gods. And if he be great and magnanimous, who coins his gold from the sinews of his bondsmen, set me down Crassus as the beloved of all greatness. 'Sblood, brother sworder, what were such a counter of silver in the iron wars? Get me up a rebellion, and you shall see this great man brained by the least of his merchandise.

ENO.

Well, I should like to be at the killing of some dozen such tyrants.

\section{PHAS.}

Why should you not? Some thousands like ourselves, Most scurvy fellows, that have been trained, like dogs, To tear each other for their masters' pleasure, Shed blood, cut throats, and do such mortal mischiefs As men love best to work upon their foes,Of these there are some thousands in this realm, Have the same wish with us, to turn their swords Upon their masters. And, 'tis natural, That wish, and reasonable, very reasonable. I am tired of slaying bondmen like myself, I am sick of it. That day the Roman knight, To win the smile of the rich quæstor's daughter, In the arena sprung, and volunteered 
To kill a gladiator, and did find

His liver spitted, like a thing of naught,

Upon my weapon,- - since that day I tasted

Of Roman blood, I have had no desire

To kill poor slaves-I've longed for naught but Romans!

ENO.

Well, we can die, and kill some, ere we die.

\section{PHAS.}

Ay, marry, some dozens;

And should those wretches be but moved to join us, We might, for dozens, count us glorious thousands.

ÆNO.

Well, we are all agreed to this. We are thirty. But how Shall we get weapons?

PHAS.

Set our dens afire,

And force the armoury.

ÆNO.

Our master, Bracchius,

Has a sharp watch to that.

\section{PHAS.}

In half an hour,

We are at our morning's practice. Now, thou knowest, To keep me in good heart, he humours me Most fulsomely. I have won him some great wagers, So I am worth his fooling. I will urge him, For this day's play, instead of laths, to give us 
True brands, for keener practice, that we may

Show nobler for him at the prætor's games.

ENO.

$<$ He knows, indeed, 'tis needful we have ready, For these same games, the best of skill:> I've heard That Lentulus the Capuan brings a troop Of excellent swordsmen on that day.

\section{Phas.}

What, excellent?

Did I not beat his boaster?-Excellent?

\section{ENO.}

'Tis rumoured so.

PHAS.

By Jove, we will put off

This thing a day! I have seen no excellence In weapons for a month.

\section{ENO.}

Why need you see it?

\section{PHAS.}

Nay, if he have a man to meet a man, I must be in the arena: No desertion, When there's a peril to be dared and ended! Faith, I will have a bout, if it but be To make Rome talk. You shall see, Anomaiis, If he be matched with me in the Thracian combat, How I will use that trick my brother taught me, When first I flashed a weapon. 
ÆNO.

I doubt not,

You will maintain your reputation.

PHAS.

Faith,

I'll hear once more this Roman acclamation, Ere it be changed to curses.

ENO.

See! Our master-

PHAS.

Well, get you gone.

ENO.

Forget not for the weapons.

PHAS.

Ay, ay-after the shows.

(Ex[i]t. AnomaIIs and the Gladiators. Enter BRACCHIUS.)

BRAC.

How now, Phasarius; what did these cutthroats here? Idling, Sirrah?

PHAS.

No; they were moralizing over their scars, and asking what they had got by 'em.

BRAC:

Do the rogues think themselves soldiers, that their cuts should be worth anything but showing? 
PHAS.

No. But some of them hope to be made freedmen one day, when they are no longer fit for the arena.

BRAC.

Fellow, thou knowest I love thee, and will enfranchise thee.

\section{PHAS.}

Yes,- - when my eye is dimmed, my arm stiffened, my heart chilled, my head gray: I look for redemption no sooner. I am a lusty, serviceable rogue yet: Why should you free me now?

\section{BRAC.}

Sirrah, are you insolent? I will have the centupondium to your heels, and the lash to your shoulders.

\section{PHAS.}

Which will make me fight the better at the prætor's games, hah! Which of us is the lunatic?

\section{BRAC.}

What, you knave!

PHAS.

Thou art my master; but I know, thou wouldst as soon set me free, as scourge me. Both would destroy thy subsistence, and one thy life; in either case, I would fight no more. And if thou wert to touch me lawfully with the thong, thou knowest, I would unlawfully murder thee. 
BRAC.

You shall be crucified!

\section{PHAS.}

Then shall the crows pick forty thousand crowns from my bones; for so much are these muscles worth.

BRAC.

Out upon you, villain! It is my favour has made thee so insolent.

PHAS.

It is my knowledge of my own price, and not thy favour, which is more perilous than thine anger. Pr'ythee, threaten me no more; or I shall grow peaceable, and spoil thy fortune.

BRAC.

You have sworn never to decline the combat.

PHAS.

Ay; so I have. But I have found no one regards a slave's oath; and why now should the slave? It is my humour, and not my oath, makes me a shedder of blood. But the humour may change.

BRAC.

Well, thou art a most impudent talker; it is eternal Saturnalia with thee. But I forgive thee, and will do thee more kindness than I have done already. 


\section{PHAS.}

Which is to say, you have some new jeopardy to put my neck in. You have some gladiator of fame you would have me fight, is it not?

BRAC.

Ay, if rumour be worth the noting. Crassus has hired the gladiators from Capua; and, 'tis said, Lentulus will bring with them a man that will cut the coxcomb from thy pate, and utterly annihilate thee.

\section{PHAS.}

They say so? Annihilate me!

BRAC.

Faith, 'tis so reckoned, and strong wagers are making against you.

\section{PHAS.}

Hah? Against me? Annihilate me! If he have a head of adamant and a breast of brass, he may do it; but if his scull be common bone, and his skin no thicker than bullhide-Mehercle! let me see this Cyclops.

BRAC.

Now, by Jupiter, I love thy spirit.

\section{PHAS.}

Has he no name? No country? No voucher of triumphs? Marry, for a mushroom, a thing that was yesterday unknown, his credit is a jot too 
arrogant; and, as I am a Thracian, and feel the blood of the warlike god, the father of Thrace, still tingle in my fingers, I will make my iron acquainted with his ribs.-Out upon him,Annihilate me!

\section{BRAC.}

Come, thou art his better; but he is noted enough to make thy triumph the more glorious. Put thyself in the meanwhile to practice. But who comes here? What, Lentulus of Capua?

\section{(Enter LENTULUS.)}

By mine honesty, I am glad to see thee. Bringest thou any new cutthroats? What man, here is my Mars of gladiators, my most unmatched and unmatchable, Phasarius the Thracian. Look how lusty the knave looks! Hast anything fit to be slashed by such a fellow?

\section{LENT.}

Nay, I know not. 'Tis a most gallant villain. <Slew he not six at the shows given by Gellius the consul?

\section{BRAC.}

Yes, by Mars; and would have made eel's meat of the seventh, but that the people grew pitiful and pointed their thumbs.- - could have cuffed 'em, senators and all.- He had him on his hip, his body bent round him thus, his fist to his poll, his dagger to his throat. By Mars, 'twas the noblest sight I had seen for a month: and yet 
when he looked to them for the doom, the pitiful things cried Nay.-I could have cuffed 'em!>

\section{LENT.}

But is he thy best man?

\section{BRAC.}

The best in Rome. I have a Gaul too; but he is not his equal. I would thou hadst a match for either. Crassus will pay: the best gladiator in the land were no loss, if killed in his service.

\section{LENT.}

I have brought some indifferent good fellows: and one of them, I think, I would wager against your unmatchable.

\section{BRAC.}

Hearest thou that, Phasarius? Get in and practice. (Exit Phasarius.)

\section{LENT.}

But he will not take the gladiator's oaths.

\section{BRAC.}

What, is he slave or felon?

\section{LENT.}

A slave that I bought of the quxstor just returned from the army of Thrace; a shepherd, I think, they told me, and leader of a horde of his savage countrymen. I bought him on the faith of the fame he brought with him, of being the most desperate, unconquerable, and, indeed, skilful 
barbarian in the province. < Thou hast not forgot Caius Clypeus, the centurion, that fought in the shows at the funeral of Sylla?

BRAC.

He was accounted on that day the second swordsman in Rome.

LENT.

His bones, with those of two of his followers, are rotting on the banks of the Strymon. The three attacked the valiant savage, my bondman; and by Jupiter, without other help than fortune and extraordinary prowess, he slew them all.

BRAC.

Hercules! he has magic weapons!> But how was he taken?

\section{LENT.}

Betrayed by his follower, while he slept; and yet he had vengeance on his betrayer, for he dashed his brains out upon a rock.

BRAC.

Excellent! Dash his brains out! He is a Titan. I would have given a dozen common slaves to have seen him do that thing!

\section{LENT.}

But he will not swear.

\section{BRAC.}

Come, thou knowest not the nature of these fellows.

Didst thou speak him kindly? 


\section{DRAMATIC WORKS OF ROBERT BIRD}

\section{LENT.}

Ay: but I had better have talked softly to a hyena: he did but scowl at me. Faith, he will sit yon by the day, looking at his chains, or the wall; and if one has a word from him, it is commonly a question, How many leagues he is away from Thrace.

BRAC.

Didst thou tell him of the honours of a gladiator?

LENT.

Ay; and he asked if cutting throats was the most honourable occupation in Rome?

BRAC.

By Mars, thou shouldst have scourged him.

I did.

LENT.

BRAC.

And how wrought it?

\section{LENT.}

I think the knave had killed me, when I struck him, - ay, even with his manacled fist,- - but that he was felled by the staff of my freedman. I should have hanged him, but was loath to lose so bold a varlet. Wherefore I had him scourged again, and faith he took it as passively as a stone. But it will not make him swear.

\section{BRAC.}

Didst thou vow to the gods to hang him up like a dog, if he were so obstinate? 
LENT.

I had a halter put to his neck; but then he laughed, and thanked his barbarous gods for such indulgence.

BRAC.

Nay, this is a madman.

\section{LENT.}

I had the fetters taken from his arm, and sent one to attack him with a weapon. But although I laid a sword by him, he would not use it; yet he struck the assailant with his fist, and felled him as one would a wall with a battering ram. But then he was angry. Another time, he sat still, and let the slave wound him, unresisting.

BRAC.

Moody caitiff! Thou hadst better drown him.--Look thou-Mine eyes are dim-I have bought a troop of women and children-Thracians too-and I think those be they coming yonder.

LENT.

Thou art mistaken. Those are mine own cutthroats, and the wild Thracian among them.

BRAC.

Why didst thou bring him to Rome?

LENT.

In a last hope to urge him to the oath. Look, is he not a most warlike and promising fellow?

(Enter Spartacus, chained, and Florus with the CAPUAN Gladiators.) 


\section{I4 DRAMATIC WORKS OF ROBERT BIRD}

BRAC.

A Hercules, a Mars! What, thou rogue, why dost thou droop thus? Why art thou so sullen and obstinate? No words? What, canst thou not speak?-Fetch me a scourge hither-I'll find thee a tongue.

LENT.

Come, sirrah, look up, speak, show thyself.

SPART.

Is it a thousand leagues away to Thrace?

LENT.

What, thou fool, wilt thou always be harping on Thrace?

'Tis so far away, thou wilt never see it more.

SPART.

Never.

LENT.

Why I say, never. Why wilt thou be so mad as to think of it?

SPART.

Have Romans fathers, and wives, and children?

BRAC.

Truly! Thou art a Thracian; what is thy name? SPART.

Misery. 


\section{LENT.}

Thou seest!.

\section{BRAC.}

Faith, thou hast scourged him too much; thou hast broke his heart. Come, sirrah, dost thou love thy country?

\section{SPART.}

I have none,-I am a slave. I was bought; I say, I was bought. Do you doubt it? That man scourges me; thou didst threaten me with stripes; every Roman I look upon, speaks to me of scourging. Nay they may: I was bought.

\section{LENT.}

Thou seest, Bracchius! This is the manner of his obstinacy.

BRAC.

Nay, I see more than thou thinkest. I can move him yet.-Observe him.- - He mutters to himself.

SPART.

Is not this Rome? The great city?

BRAC.

Ay; and thou shouldst thank the gods they have suffered thee to see it, before thou diest.-

\section{SPART.}

I heard of it, when I was a boy among the hills, piping to my father's flocks. They said, that spoke of it, 
it was the queen of cities, the metropolis of the world. My heart grew big within me, to hear of its greatness. I thought those men who could make it so, were greater than men; they were gods.

LENT.

And are they not, sirrah?-

\section{SPART.}

How many palaces, that look like the habitations of divinities, are here about me! Here are marble mountains, that have been hewn down and shaped anew, for men to dwell among. Gold, and silver, and purple, and a million of men thronging the pillared hills!

BRAC.

And what thinkest thou, now thou hast seen it?

\section{SPART.}

That,-if Romans had not been fiends, Rome had never been great! Whence came this greatness, but from the miseries of subjugated nations? How many myriads of happy people-people that had not wronged Rome, for they knew not Rome -how many myriads of these were slain like the beasts of the field, that Rome might fatten upon their blood, and become great? Look ye, Roman,-there is not a palace upon these hills that cost not the lives of a thousand innocent men; there is no deed of greatness ye can boast, but it was achieved upon the ruin of a nation; there is no joy ye can feel, but its ingredients are blood and tears. 
LENT.

Now marry, villain, thou wert bought not to prate, but to fight.

SPART.

I will not fight. I will contend with mine enemy, when there is strife between us; and if that enemy be one of these same fiends, a Roman, I will give him advantage of weapon and place; he shall take a helmet and buckler; while I, with my head bare, my breast naked, and nothing in my hand but my shepherd's staff, will beat him to my feet and slay him. But I will not slay a man for the diversion of Romans.

BRAC.

Thou canst boast, barbarian! If thou canst do this, what brought thee to Rome, a captive?

\section{SPART.}

Treachery! I was friendless, sick, famished. My enemies came in numbers. They were like the rats of Egypt, that will not come near the crocodile while he is awake: they attacked me sleeping. Had they found me with a weapon in my hands, Gods! I had not now been a thing for Romans to scourge.

BRAC.

Fellow, I love thee. What is thy name?

SPART.

What matters it? 
Wilt thou be free?

BRAC.

Free!

\author{
SPART.
}

BRAC.

Take the oaths of a gladiator, and kill me a score of lusty fellows-

\title{
SPART.
}

A score! kill a score of men? in cold blood? and for the diversion of Rome's rabble? I will not.

BRAC.

By Mars, then you shall be sent to man young Cæasar's galleys, and be whipped daily.

LENT.

Fight me half a score, and, by Jupiter, I will send thee back to thy wife.

SPART.

My wife!-The last thing that mine eyes looked on, When my steps turned from Thrace, it was my cottage A hideous ruin; the Roman fires has scorched it:

No wife sat sobbing by the wreck; no child Wept on the sward; not even the watchdog howled: There was no life there.-Well, why should I talk? 'Tis better they are perished.

\section{LENT.}

The slave is reckless.-

This is despair : 
SPART.

$O$ ye heavens! that sight

Withered my heart; I was a man no more.

I had been happy too!- Had ye spared them,

Then spoke of freedom, you should have had my blood,

For beastly ransome: All integrity

And pride of heart I would have sold for it.

BRAC.

Sirrah, there are more wives in Thrace.

LENT.

Lo now!

He'll speak no more.-You, Bracchius, have more skill To move these obstinates. You shall buy him of me.

\section{BRAC.}

And hang him! Marry, not I. He is a madman.

I have some better merchandise here now,

Not warlike, but as gainful.

(Enter SENONA, with a child, and other slaves.)

Thou seest these creatures:

Here are some Thracians too.-The moody villain! He should be hanged.-The Thracian women are Most excellent spinners. Buy a brace of them For your wife. I care not for so many.

\section{LENT.}

This woman

That weeps so, she with the brat,- -is she a Thracian?

\section{BRAC.}

Hark ye, mistress, answer-are you of Thrace?

One might swear it by her silence; for these savages 


\section{DRAMATIC WORKS OF ROBERT BIRD}

Are always obstinate at the first. You like her? Well, out of my friendship now, I'll almost give her to you.

Three thousand drachmas-

\section{LENT.}

Three thousand furies!

BRAC.

Ay, with the boy too-'Tis a lusty imp.

LENT.

Three thousand sesterces; and that's too much.

BRAC.

Jove! talk of sesterces? This cub is worth it! (BRAC. handling the child roughly.)

SENO.

Ah, hurt him not.

SPART.

Hah!

LENT.

Three thousand sesterces.-

SPART.

Did my ears mock me?

BRAC.

For the woman alone.

Well then sesterces, 


\author{
SENO. \\ You will not part us? \\ SPART.
}

Hahl

Gods, pity me! does the grave give back the dead? Senona!

SENO.

Hah! Hah! My husband!

BRAC.

What's the matter?

LENT.

A bargain-

BRAC.

What, his wife? Six thousand drachmas. No more sesterces!-Caitiff, is this thy wife?-(To SPART.)

SPART.

And my miserable boy too, Exposed in the street to sell!

BRAC.

Six thousand drachmas.

By Jove, I have you.

SPART.

Why didst thou not die?-

Villains, do you put them up for sale, like beasts? Look at them: they are human. 
LENT.

Silence, rogue.-

SPART.

I will not silence. I will ransome them, What way you will, with life or blood.-

BRAC.

By Jove,

I will not sell her. Into the house, get in.Take her along.

SPART.

You shall not-I will brain that man That lays his hand upon her.

BRAC.

Kill the villain.-

SPART.

Man, master!-See, I am at your feet, and call you, Of mine own will, My Master I-I will serve you Better than slave e'er served;- grant me this prayer, And hire my blood out. Buy-yes, that's the word; It does not choke me-buy her, buy the boy; Keep us together-

BRAC.

Six thousand drachmas-

SPART.

Though they were doubled.

I will earn them, 
LENT.

Will you fight?

SPART.

And die.

LENT.

Die! Then my gold is lost.

\section{SPART.}

I will not die.-

Buy them, buy them.

LENT.

And you will swear?

SPART.

To be a cutthroat and a murderer,-

I will,Whate'er you will,--so you will buy them.

LENT.

Unbind him.

BRAC.

Six thousand-

\section{LENT.}

Three. Remember, Bracchius,

If you prevent his fighting, your own profit Suffers as well as mine.

BRAC.

Five thousand then. 


\section{LENT.}

Nay, pr'ythee, four.

BRAC.

Well, out of friendship,

It shall be four.-But, faith, my Gaul shall kill him.

\section{LENT.}

We shall see. I'll wager even, and no less

Than the purchase money.-

\section{SPART.}

Come dry your tears, Senona:

We are slaves: Why should slaves weep?

SENO.

$O$, dear my husband,

Though I ne'er thought to have the joy to meet you Again, in this dark world, I scarce feel joy-

I think, my heart is burst.

\section{SPART.}

Come, be of better cheer:-

Art thou not now amid the gorgeous piles Of the potential and the far-famed Rome?

SENO.

But $\mathrm{Oh}$, the hills of our own native land! The brooks and forests-

\section{SPART.}

Think of them not.-

Ah! no more, no more: 
SENO.

Where we fed sheep, and laughed To think there could be sorrow in the world; The bright, clear rivers, even that washed the walls Of our burned cottage-

\section{SPART.}

No more, no more, no more. Are there not hills and brooks in Italy, Fairer than ours? Content you, girl.

SENO.

$$
\text { Alas, }
$$

This boy must be a Roman, and a slave.

\section{SPART.}

By heaven, he shall not! Free as rock-hatched eagles, Thy boy was born, and so shall live and die!We wear our fetters only for a timeRomans are not all like these men. We'll see Our home yet. We are slaves but for a time.I need not ask thee for my mother, girl:

I know this thing has slain her. Her heart cracked, When they bore off my brother.

\section{LENT.}

With the Gaul then:

And if he beat him, as I think he will, Then shall he battle with your best.-Now, sirrah.

Hah! 
SENO.

Husband!

SPART.

Well, it is not chains alone

That make the slave. What will my master have?

LENT.

I'll have thee exercise thine arm in practice. Thou wilt have brave men to contend with.

SPART.

I will do so: but speak it not before my wife.

Well,

LENT.

Get thee along. Florus, conduct them to Their lodgings. See this Thracian exercised.

(Exeunt.)

END OF ACT I. 


\section{ACT II}

SCENE I. A room in Crassus's house. Enter Crassus, Jovius, an Artificer, and a Slave.

\section{CRASSUS}

To the full letter of the law. What, use My excellent slave in thy most gainful craft, And groan at the reckoning? By Jupiter, Thou shalt his hire pay to the utmost sesterce, Or have a quittance writ upon thy back. Breed I then servants for the good of knaves? Find me the money, or I'll have thee whipped. Begone. (Exit Artificer.) I built not up my fortunes thus,

By taking sighs for coin: had I done so, Foul breath had ruined me. How should I then Have borne the hard expenses of these games, The uproarious voters clamour for?

Jov.

What! true.

Wealth is the key to office, here in Rome,Or is the lock that best secures it.

C RASS.

Sirrah, Thou dost not mean, the officers bribe the people? 
Jov.

I had sooner lug old Cerberus by the ears, Than do aught to our citizens, but praise 'em. But, in your gracious ears, -our sovereign Romans Are something bauble-brained; and, like to children, Pass qualmish by their needful medicines, To snatch at sugary playthings. What do they In their elections? Faith, I have observed, They ask not if their candidate have honour, Or honesty, or proper qualities;

But, with an eager grin, What is his wealth? If thus and thus-Then he can give us shows And feasts; and therefore is the proper man. An excellent mode of judging!

\section{CRASS.}

At me thou point'st now.

Ancient comrade,

Jov.

Not irreverently:

I question of the people; and, I think,

They loved great Marius more for his rich feasts, Than his rich victories. Sooth, when angry Sylla Swept them, like dogs, out of his bloody path, And made their hearts sore, they forgot their fury, When once they had looked upon his fighting lions.

\section{CRASS.}

Hence, thou inferrest, they have chose me prætor, Being rich enough to purchase them diversions! But I have done them service in the wars, And, out of gratitude-But no more of that.They shall be pleased: the games go bravely on. 
The Capuan hath brought me a new sworder.Sirrah, go bid my niece here (Exit Slave.) This Capuan hath

A son most insolent and troublesome.

(Enter FlORUS)

What, Sirrah, again? Hast thou not had thy answer? $<$ Kill me these flies that being lean themselves, Swarm after fatness. $>$ Why art thou this fool, To covet my rich niece?

FLOR.

I seek not riches.

CRASS.

Pah! Will poor lovers sing eternally The self-same song? They seek not riches! Jove, Why pass they then all poverty, where their choice Might find a wider compass?

FLOR.

Excellent prætor,

Give me the maid, and keep her lands thyself.

CRASS.

Sirrah, thou know'st, the girl abhors thee. Look, She has the blood of nobles in her veins, Distilling purely through a thousand years; And thine comes grossly from a German slave's, That was thy grandsire.

FLOR.

Worth and deserving toil can raise me up, Even from my poverty, to wealth and honours. And these shall do it. 
CRASS.

Get thee away then

To warring Pompey, and, with thy soiled sword, Carve out clean honours; not forgetting, whilst Thy right hand grasps the enemy's throat, to thrust

The left into his purse: For what is honour, With empty pockets, in this thievish world?

Honour is men's consideration: men

Consider none, but those can profit them.

Therefore, if thou'lt be quick

In gaining honour, use thy right hand rather

For gathering gold than killing-or rather use them both:

Make much, and thou shalt be most honourable.

Jov.

Thou hearest, Florus? This is the truer wisdom.

I've fought for honour some good thirty years, -

$<$ Courting her with such madman freaks, as leaping,

First man, upon an arm'd wall in the storm; Saving a comrade's life (some dozen of 'em,) Out of the jaws of death; contesting singly With scores, in divers places. > But being foolish, In my hot haste for slaughter, I forgot To look for spoil; and lo, the consequence! I bear the vine-branch, ${ }^{\mathrm{I}}$ and am only honoured As a gray-haired centurion.

I The MS. contains the following note, written in Bird's hand: "This (the vine branch) was the badge of a centurion's office, and he should carry it-at least in camp and in his embassies." 


\section{CRASS.}

Get thee gone.

When thou art worthy, ask her, and no sooner.

(Exit FloRUs.)

A most mad, insolent boy, and honest son

Of a breeder of cutthroats! Would some knave would hang him.

He has the damsel's heart too. See, she comes.Is the litter ready?

(Enter JUlia.)

JUL.

It cannot be, dear uncle,

You will send me to the country?

\section{CRASS.}

It cannot be!

What, chuff, it cannot be? In faith, it can be, And, instantly, it shall be:-Into the country, To weep and meditate. I am ashamed

You have so poor a spirit as to love

This base-born Capuan, whose whole wealth you might,

Piled up in coin, base on a puny drachma.

$$
\text { JUL. }
$$

Ah! When did love e'er think of drachmas, uncle?

$<$ You would have me, when a lover moans, demand him,

Could he coin gold, as easily as sighs;

Or when he wept, ask if his pockets had As many talents as his eyes had tears. 
Then should he change his manner, and where he might

Have wooed me with soft words, assault me with

A schedule of his properties; instead

Of flattering, boast me of his lands; his vows

Change into oaths of, lord, how rich he was.

How could I say him nay?>

CRASS.

A milksop boy,

That has done nothing in the world but breathe,Has won no name or fortune. Why should such A natural expletive, <a sack of breath, >

Aspire to wealth or woman? When he proves him Worth his existence, then let him aspire.

Till then thou shalt be hid from his presumption, Even in Campania.

JUL.

Oh, but not today.

Tomorrow, or the next day, when the games are done.

I must see them: 'twould kill me, not to look

Once more upon the fighting gladiators.

\section{Pho!}

CRASS.

Thou a green girl, and talk of gladiators!

My youth was pass'd in battles, and I am not Unused to blood; but my flesh always creeps, To see these cold-blood slaughters.

JUL.

So does mine.

Ugh! my heart stops with terror, and my eyes Seem parting from their sockets; my brain reels, 
While I look on; and while I look, each time, I swear I ne'er will look again. But when They battle boldly, and the people shout, And the poor creatures look so fearless,-frowning, Not groaning, when they are hurt:-Indeed 'tis noble! $<$ And though they fright me, always make me weep, I love to see them. These are your own shows: $>$ $\mathrm{Oh}$, I must see them.

$$
\text { Jov. }
$$

This is a brave maiden.

$<$ You should look on a battle-two great armies, (Perhaps a hundred thousand men apiece:)

Fighting as staunchly as so many wolves, Throttling and stabbing, dying in multitudes,A chaos of death:-Even such a one as that (My own first fight) at Aqua Sextia, Against the Ambrones, where a hundred thousand Of the barbarians fell.

JUL.

An hundred thousand!

Jov.

Was it not glorious?

JUL.

Horrid!

Jov.

Horrid! Humph, Still woman.-But these were barbarians. 


$$
\text { JUL. }
$$

Were they not men?

$$
\text { Jov. }
$$

Why yes, a sort of men.

They had legs and arms, noses and eyes like men, They bled like men; but, being barbarians, Of not much matter of account as men.

JUL.

That makes a difference. But an hundred thousand Was many to kill, even of barbarians.

\section{CRASS.}

Come, you're a goose, you know not what you say.

JUL.

O but these gladiators! My friend, Caloeia, Told me that famous one, Phasarius, Would fight today. He is a handsome rogue, And kills a man the prettiest in the world.>

CRASS.

You shall not see him.

JUL.

Dear my uncle.

CRASS.

You came

Into this city, modest and obedient;

Now you have learnt to cog, cajole and cozen;

And, in the teeth of my authority, 
Give private hopes to this low Capuan; And, while mine eyes are tied upon the games, Would-But I'll balk your hoped for interviews. The litter waits you at the door. Farewell. This good old man, who once was my tried client, Shall have you in charge. Now no more opposition. Farewell. Be wise, and love none but the worthy.

(Exeunt.)

SCENE II. A court before LENTULUs's house. Enter Florus with Spartacus, CRIXUs, and other Gladiators.

FLOR.

You have played well, and beaten Crixus fairly.

Carry this skilfulness to the arena, And you shall win great honour.

SPART.

No matter: I am sworn to be a caitiff.

Great degradation.

Where have you placed my wife? It was conditioned, You should not part us.

FLOR.

She is lodged hard by:

After the combat, you shall see her.-Come, Play me a bout here with Soturius.

I'll fetch you foils.

SPART.

I'll play no more: I was not sworn to that. 
FLOR.

You cannot go too well prepared.

SPART.

Even as I stand,

Awkward or skilful, doomed to die or kill, So will I go.-I'll train no more for murder.

Well, as you will.

\section{FLOR.}

$$
\text { SPART. }
$$

Will it not be enough,

If I disarm or worst my enemy?

May I not spare him?

FLOR.

Not unless the people

Grant you permission. <When you have him at Your mercy, look to the spectators then.

If they consent, they will their thumbs raise-thus: Then you shall spare. But if their hands be clenched, And the thumbs hid, then must you slay. $>$

$$
\text { SPART. }
$$

I understand.

$$
\text { Well, well: }
$$

\section{FLOR.}

Breathe yourselves here awhile,

Then follow to the armoury.

SPART.

Good brother,

Have you yet fought i' th' Amphitheatre? 
CRIX.

$$
\text { Ay. }
$$

SPART.

And killed

Your adversary?

CRIX.

Ay. Each one of us

Has won some reputation.

\section{SPART.}

Call you this reputation?

Reputation!

This is the bulldog's reputation:

He and the gladiator only need

The voice $o^{\prime}$ the master, to set on to mischief.Love you your masters?

CRIX.

No.

SPART.

Go ye to perish?

Or of your own wishes

CRIX.

No; but being slaves,

We care not much for life; and think it better

To die upon the arena, than the cross.

SPART.

If ye care not for life, why die ye not Rather like men, than dogs? 
338 DRAMATIC WORKS OF ROBERT BIRD

CRIX.

What mean you?

SPART.

Were it not better

To turn upon your masters, and so die, Killing them that oppress you, rather than fall, Killing your brother wretches?

CRIX.

True, it were.

Put arms into our hands, unlock our dungeons, And set us out among the citizens;

Then ask this question.

SPART.

Do you say this? By heaven,

This spirit joys me.-Fight ye all today?

\section{CRIX.}

We are so ordered.

SPART.

How many do you number?

CRIX.

Fifty.

SPART.

Fifty? How many hath this Roman, This villain Bracchius?

CRIX.

Some five and thirty. 


\section{SPART.}

And fight they all?

CRIX.

Some forty pairs today.

SPART.

$\mathrm{O}$ heaven, what, forty?

CRIX.

And ere the shows are done,

Two hundred pairs.

SPART.

Two hundred pairs!-Four hundred

Arm'd slaves, that hate their masters!

CRIX.

On the third day,

All that survive, will fight in general battle.

SPART.

In general battle!-If Senona now, And the young infant were in Thrace.-Alas, To peril them.-

CRIX.

What say'st thou, Thracian?

SPART.

Nothing;

At least, not much.-Are there now troops in Rome? 


\section{DRAMATIC WORKS OF ROBERT BIRD,}

CRIX.

Four legions of Prætorian Guards; and now Each legion counts five thousand.

\section{SPART.}

'Twill not do.

CRIX.

What will not do?

SPART.

I'll tell you by and by:

'Tis worth your ear.-But let us now go arm, Then to the Arena, to begin the work Of slavish murder.-We are gladiators.

(Exeunt.)

SCENE III. The Arena of an Amphitheatre, behind which are many citizens. CRASSUS seated with his Lictors, Mummius, Lentulus, Bracchius, Florus, and many officers,-Aidiles, Conquisitores, etc.

\section{CRASS.}

Let our good friends, the citizens, be seated. We purpose to delight their humours with The bravest gladiators of this realm.What say'st thou, Capuan? Why tell me, thou Hast brought me some brave cutthroats, to be pitched, Through the first hours, in single combat, with The best slaves of our Bracchius.

LENT.

Even so,

Most noble prætor; and, with the consent 
Of your appointed officers, we first

Will bring a lusty Thracian, who, although

Yet unadventured in the Arena, bears

A name of valour.

CRASS.

Let him before us.

(Exit FLORUS.)

Had Thracians, by their firesides, fought as fiercely As now they fight upon the Roman sand, The cranes o' the Strymon still had been their sentries.

(Reenter FloRus, with SPARTACUS, as a gladiator.)

Is this the man? A very capital knave;

Yet, or I err, of but a little spirit.

Where is the fiery confidence, should flash

From his bold eyes? the keen and tameless spirit, Should brace his strong limbs to activity?

\section{LENT.}

Driveller, arouse thee!-Let not his gloom condemn him:

$\mathrm{He}$ is most wayward, but, in truth, right valiant.

What, sirrah, shake off these clouds, and do thy homage

To the most noble prætor. Bend thy knee.

\section{SPART.}

Did I swear that? Kneel thou, whose servile soul Was given for crouching. I am here to fight!

CRASS.

This is some madman! 
$34^{2}$ DRAMATIC WORKS OF ROBERT BIRD

LENT.

A barbarian,

Bred in a savage roughness.

\section{SPART.}

Well, I am here,

Among these beasts of Rome, a spectacle.

This is the temple, where they mock the Gods

With human butchery,-Most grand and glorious

Of structure and device! - It should have been a cave, Some foul and midnight pit, or den of bones,

Where murder best might veil himself from sight.Women and children, too, to see men die,

And clap their hands at every stab! This is The boastful excellence of Rome! I thank the Gods There are Barbarians.

CRASS.

Now by Jupiter,

The rogue speaks well-But Romans must be pleasedSirrah,- (Comes down center.)

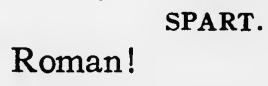

CRASS.

Most impudently bold.

I did mistake him. Prepare thyself.

\section{SPART.}

As ready to die, as thou to see me die.

I am ready, Where is the opponent? Of what nation comes The man that I must kill? 
CRASS.

What matters it?

SPART.

Much, very much. Bring me some base ally Of Roman rapine, or, if ye can, a Roman:I will not grieve to slay him.

CRASS.

Faith, I like

This fearless taunting, and will sound it further. Thy foe shall be a Spaniard.

SPART.

\section{Alas, I should}

Bethink me of his country, as of mine, Ruined and harried by our common foe; His kinsmen slain, his wife and children sold, And nothing left of all his country's greatness, Save groans and curses on the conquerors.

\section{CRASS.}

A Carthaginian.

\section{SPART.}

What, a Carthaginian?

A relic of that noble tribe, that ne'er Would call Rome friend, and perished rather than Become Rome's vassal? I could not fight with him: We should drop swords, and recollect together, As brothers, how the Punic steel had smote, Of yore, to Rome's chill'd heart; yea, how Rome quaked, 
How shook her proud sons, when the African Burst from the sea, like to its mightiest surge, Swept your vain shores, and swallow'd up your armies! How, when his weapons, gored with consular blood, Waved o'er your towns, your bucklered boasters fled, Or shook, like aguish boys, and wept and prayed:Yea, feared to die, and wept and prayed.

LENT.

$<$ Peace, villain. $>$

CRASS.

Strike him not, Lentulus. The prattler knows There's scarce a man of the Punic stock left living, To boast of these mishaps.-Thy adversary Is a brave Gaul.

\section{SPART.}

Why there again! The name

Speaks of Rome's shame. Name but a Gaul, and I Bethink me of the Tiber running blood, His tributaries choked with knightly corses; Of Rome in ashes, and of Brennus laughing At the starved cravens in the Capitol.

\section{CRASS.}

Sirrah, no more.

Be but thy sword as biting as thy tongue, And I'll assure thee victory.-Bring in The Gaul. Use thy best skill, if skill thou hast, Or I'll not lay an obolus on thy life.-

(A Gallic Gladiator is brought in.)

Clear the Arena (Ascends chair again). 
SPART.

I will fight with him;

But give me to spare his life.

CRASS.

That privilege

Rests with the people. Remember thy oath.-Sound, trumpets.

(A flourish.)

Brother-

SPART.

CRASS.

No words; but do thy best. <He'll spit thee.>

(They fight. The Gaul is disarmed, and thrown on his knees. SPARTACus looks to the people.)

Thine oath! Strike, <villain!> Hah!

(SPartacus kills the Gaul.)

Why that was bravely done.

SPART.

Well, I have done it. Let me go hence.

CRASS.

Not so.-

Most nobly fought!

SPART.

Alas, alas, poor slave!-

CRASS.

Bring me another.

(The body is taken away.) 
SPART.

I will fight no more.

\title{
CRASS.
}

Sirrah!

SPART.

I have heart enough to die, but not to kill.

CRASS.

Why 'twas most capitally done! Remember Thy oath.

\section{SPART.}

I care not. I will fight no more.

\section{CRASS.}

Thou shalt have freedom. Nay, I'li ransome for thee, Thy wife and boy.

\author{
SPART. \\ Wilt thou?
}

CRASS.

By Mars, I will.

Fight through these games; and thou and they shall be Sent back to Thrace.

\section{SPART.}

Shall we see Thrace again?-

Let him come on; yes, though it sick my soul,Let him come on. 
CRASS.

Bring in the Thracian!

(Exit BRACCHIUS.)

SPART.

Thracian?

I will not fight a Thracian! 'Tis my countryman!

CRASS.

Nay, but thou shalt, and kill him too; or thou And they, are slaves eternally.

SPART.

O heaven!

Bring me a Spaniard, German, Carthaginian, Another Gaul, a Greek-any but Thracian.

\section{CRASS.}

None

But this same Thracian is thy match; and truly If thou slay him, there will remain no other Worthy of thee. Thou shalt be quickly free.

SPART.

I will fight two-three-so they be not Thracians.

CRASS.

The Thracian, or eternal bondage; bondage For wife and child too.

SPART.

Wilt thou swear to free us?

Fight with a Thracian!-Wilt thou swear to free us? 
CRASS.

Bring hither the Vindicta: With this rod, If thou escape this man, the prætor frees thee.

(Reenter Bracchius, with Phasarius.) This is thy foe.

PHAS.

(Aside.) What, do I dream?

SPART.

Alas,

Thou art a Thracian and my countryman, And yet we meet as deadly foes. Forgive me.

PHAS.

(Aside.) This is no fantasy!

CRASS.

Observe them, Bracchius:

Thy boaster hesitates.

PHAS.

Thou art a Thracian?

SPART.

Would thou wert not.

PHAS.

Of the Ciconian tribe-

A son of blue-waved Hebrus?

SPART.

Such I am.

And comest thou too of the same race? and set Against thy brother? 
PHAS.

Brother, indeed!

Thy name is Spartacus.

SPART.

Where learn't you that?

Freemen have heard it, but not slaves.

PHAS.

How fares thy father?

SPART.

Didst thou know him?-Dead-

I cannot fight thee.

PHAS.

Hadst thou not a brother?-

CRASS.

Why prate these cutthroats? Come, prepare, prepare-

\section{SPART.}

A young, brave heart, whose steps I taught to dare The crags and chasms and roaring cataracts Of his own native hills, till he was freer Among them than the eagles. What art thou, That seem'st to know him? I would be angry with thee:

These words make me look on thee as a friend.

\section{PHAS.}

Seem I not like Phasarius? 


\section{DRAMATIC WORKS OF ROBERT BIRD}

SPART.

What, thou?

A mailed warrior like a singing boy?The Romans slew him.

PHAS.

They enslaved him-Brother,

Changed as I am, and from a harmless boy, Turned to a rough destroyer, still am I The selfsame fool that once thou called'st brother.

SPART.

Thou mock'st me. Thou!

PHAS.

My father, Menalon-

SPART.

Thy father, Menalon?

PHAS.

My mother-

SPART.

Ay, thy mother?

PHAS.

Laödice.

SPART.

My brother!

CRASS.

What mean these rogues, that they have dropped their swords,

And faln, like friends, about each other's necks? 
What ho, ye slaves, give o'er this timeless juggling:

Take up your swords, and look ye to the signal.

$$
\text { SPART. }
$$

I do believe the gods have given me o'er To some new madness: First, I find in Rome, Where naught I looked for but despair, my wife And then my brother!

<CRASS.

Villains!

SPART.

\section{But I am sorry}

To find thee here, Phasarius. $>$

LENT.

$<$ Whining miscreant, $>$

Why mark'st thou not the prætor?

CRASS.

$<$ Rogues, prepare. $>$

Let the trumpet sound.

SPART.

Bring me my adversary.

CRASS.

Thou hast him there.

SPART.

What he? This is my brother.

You would not have me fight with him! 
352 DRAMATIC WORKS OF ROBERT BIRD

CRASS.

His brother?

PHAS.

'Tis true, most excellent prætor.

CRASS.

This is too strange for truth.

Now, by Hercules,

\section{LENT.}

Think ye to balk us thus?

Ye cogging rogues,

< BRAC.

Conspiracy!

Shameful collusion! Out on you, Phasarius,

You're not afeard now? Out, ye cheating villain. $>$

PHAS.

Hear me, good prætor-

CRASS.

$<$ Rogues $>$, prepare yourselves.

This is a most evident knavery, to 'scape

From one another.-Brothers indeed!-Prepare;

Take up your arms.

SPART.

Foul Roman-

CRASS.

Bring me in

The guarding cohort: (An Officer goes out.) I'll have them cut to pieces,

If they refuse the battle.-Brothers indeed! 
SPART.

Thou hard, unnatural man-

PHAS.

Patience, brother-

SPART.

Let them come in-We are armed.-

CRASS.

Most strange and insolent contumacy!

PHAS.

(Aside.) 'Tis something sudden-and in Rome!Peace brother.-

SPART.

We will resist them, armed as we are.

Can we not die?

PHAS.

Most worthy prætor, pardon.

Grant us a word together, and we are ready.

\section{CRASS.}

Fine knavery! I did almost suspect

Yon cutthroat for a coward-that 'twas skill alone Gave him his courage, which he fear'd to try With that more skilful savage. For the barbarian, His soul is made of contrariety. 


\section{DRAMATIC WORKS OF ROBERT BIRD}

PHAS.

(Apart to SpaRT.) I know them all-This thing was hatch'd before.-

They wait without,

Circled by cohorts, but all arm'd for combat.

Let me but raise the cry of Freedom to them, And each man strikes his Roman to the earth.

\section{SPART.}

The slaves of Lentulus-they will strike too:

Let us but reach them, and they rise with us.-

\section{PHAS.}

One moment, princely prætor.

CRASS.

Not an instant.

What, shall our shows wait on the time and pleasure Of our base bondmen? Sound the trumpets thereWhat, treachery, ho! Call in the soldiers!-

PHAS.

Preedom

For gladiators!

SPART.

Death to all their masters!-

\section{CRASS.}

Treachery!-

SPART.

Death to the Roman fiends, that make their mirth Out of the groans of bleeding misery! 
Ho, slaves, arise! it is your hour to kill!

Kill and spare not-For wrath and liberty!-

Freedom for bondmen-freedom and revenge!-

(Shouts and trumpets-The guards and gladiators rush and engage in combat, as the curtain falls.)

END OF ACT II. 


\section{ACT III}

SCENE I. ${ }^{\mathrm{I}}$ A room in Crassus's house. Enter Crassus, Jovius, Lentulus, Bracchius, Mummius.

\section{<CRASS.}

Incredible! What, fight a consular army?

Or look one in the face?

$$
\text { Jov. }
$$

So says the courier.

'Tis sworn, that half the slaves of Italy Are flocking to his banner.

\section{CRASS.}

Fight Cneus Lentulus!

Fight a consul!

Jov.

'Tis not so much

To one who has already beat a proconsul.

You'll not doubt that? nor that these madman slaves, Led by this whirlwind slayer-

- There is a query in Bird's handwriting "whether to restore the beginning of this scene or some part of it?" It seems that Dr. Bird submitted the MS. of The Gladiator to Edwin Forrest for revision, who no doubt suggested many of the cuts indicated. 
LENT.

My precious Thracian!-

Jov.

Have vanquished severally, and in pitched battles, Three prætors of the provinces.

CRASS.

Shame upon them!

Sneers for their lives, contempt for epitaphs! Beaten by slaves! - I warrant me, by mineTwo thousand costly and ungrateful villains:I'll hang them, every man.-Beaten by slaves, Gross, starving, unarmed slaves!

Jov.

Not now unarmed.

Each rogue has got a Roman harness on, Filched from the carcass of a Roman veteran. Not starving neither, whilst every day they sack Some camp or city-pouncing sudden down, Like vultures, from their hills upon our troops.

\section{CRASS.}

Scandalous, scandalous! Slaves, wretched slaves, Led by a slave too!

\section{LENT.}

Still my precious Thracian!

CRASS.

A scurvy gladiator, with no brains; An ignorant savage.- 
Jov.

Come, give the rogue his due:

He has more brains than all our generals, For he has beaten them; that's a soldier's proof. This Spartacus, so late a bondman, has A soul for master; though a shepherd bred, He has fought battles, ay, and led men too,Some mountain malcontents in his own land,'Gainst Roman conquerors; and, by the faith Of honesty, for honest I will be, In courage, stratagem, resource, exploits, He shows a good commander. He has formed, Out of this slavish, ragged scum, an army; Arms it and feeds it at his foeman's cost, Recruits it in his foeman's territory; Which foe is renowned Rome, resistless Rome, Rome the great head and empress of the world! Is he not then a general?

\section{CRASS.}

I grant you,

The rogue is not a common one; but still A slave. And much it shames me that the senate Finds me no worthier enemy; whom to conquer, Wins neither spoil nor honour.

$$
\text { Jov. }
$$

No spoil indeed, Unless you count their arms and bodies such; But honour enough to him that beats the vanquisher Of some half score commanders: There's your honour. Come, stir these centuries: My old bones are aching For one more battering, ere they fall to dust. 
The reprobates must be put down, that's certain, And by yourself, or Pompey.>

\section{CRASS.}

Now the gods rest him!

Is there no trouble can befal the state, But men must cry for Pompey? As if Rome Had whelped no other fit to do her service. $<$ Still is it Pompey, great and valiant Pompey, Must all our state thorns conjure into laurels.Well, Crassus is not Pompey, but may serve For the besom.

$$
\text { jov. }
$$

What, a besom?

CRASS.

Ay, to sweep away

This filthy blush out of Rome's cheek.>-These varlets,

These fooled lanistee, that have trained slaves up

To fight their masters, shall to camp with me, And of the evils they have caused, partake.

\section{LENT.}

I am willing.

I'll kill my Thracian, though he be a general.

\section{BRACH.}

It matters not how soon I am knock'd o' the head.

I have not now a gladiator left.-

The rogues have ruined me. 


\section{CRASS.}

Where is thy son?

This knave shall march too. Have you brought the woman,

The wife o' the Thracian, here to Rome?

\section{LENT.}

I have sent for her.

My son has gone into Campania.

\section{CRASS.}

What, to Campania? Now by Jupiter, This fool will set me mad.

\section{LENT.}

I know not that.

He went with the band of youthful volunteers, To the camp of Gellius, the consul.

Jov.

Bravely done.

That was in memory of our counselling.

But now for action. <You remember, prætor, This consul prays immediate succours, being But ill provided, should the Gladiator, In contest with his colleague, prove victorious, As there is ground to fear; for Lentulus, At the last word, was at extremities. Being deprived too by the angry senate Of their authority, their mutinous troops But scurvily obey them.> Should the rebels Come near your country-seat- 
CRASS.

No more of that:

The consul shall protect her.-Presently

Bring me six legions; which, being added to

The consular troops and the knights volunteers,

We'll have appointed to this service. Then

There shall be knocks enough, I promise you.

See that these people follow, and all men

Whose slaves have joined the rebels. It is reason,

The rogues should kill no masters but their own.

(Exeunt.)

SCENE II. A plain in Campania, after the battle. Some corses lying about. March of trumpets. Enter, sumptuously armed, Spartacus, Phasarius, Crixus, ENOMAIIs, and Attendants.

\section{SPART.}

So, we are victors, conquerors again.

The hotbrained boasters, that in mockery thought

To ape the angry Scythian, and subdue us

With whips, instead of warlike instruments,

Lie hush'd and gory; and, despite the claim

Of their high honours and nobility,

There is no slave too base to tread upon them.

There he's a Consul.-I have known that word

Fright men more than the name of gorgeous kings.

Say to barbaric States, $A$ Consul comes,

$A$ Roman Consul, and their preparation

Of war or welcome, speaks a demigod.

And yet lies he on the opprobrious earth,

A palmy Consul, by a slave's hand slain, 
No nobler than his horse-a thing to

Glut the starved hyena's maw. ${ }^{x}$

\section{PHAS.}

Must lie beside him.

$$
\text { Ay-and there's another }
$$

SPART.

Speak you of Gellius?

PHAS.

Ay, marry. I'll fight now nothing less than consuls. There is another of them, and I say, Another battle and another victory.

CRIX.

'Tis but to will, and we have won it.

$$
\text { SPART. }
$$

Ay;

But not today. Our medly bands have earned Their armour, and are weary.-'Tis full six leagues To Gellius' camp.

CRIX.

My Germans will not fear it.

SPART.

It cannot be, and must not.

CRIX.

Must not, Spartacus?

× The original reading, struck out in the MS., was,-

In a hyena's paunch."

"-a thing to rot

The reading I have adopted is written in a hand resembling Forrest's, in pencil, and is probably his suggestion. 
SPART.

Ay, man, I say so: this thing must not be.

When ye were few, with one consent, ye chose me Your leader, with each man an oath to yield To me sole guidance. This was little honour, To be the chief of fourscore fugitives, And none would have it, save myself. I took it, And ye have prospered. Under my authority, In a few days your ranks have been swell'd up To fearful thousands; and from a band of slaves, Skulking in caves, you have become an army Can fight a Roman Consul. This is proof, I have deserved obedience; and therefore, I still command it.

CRIX.

And my countrymen

Myself have made their leader; and they bid me Lead them to Gellius.

SPART.

We are but one army,

With but one object, howsoe'er our ranks Are filled with various nations. We are slaves, All of us slaves, contesting for our freedom; And so far free, that we have arms and kill; No further. We have yet to cut our way Out of this tyrant empire; which to do, We must destroy more armies, that are gathering To hem us in. We do not fight for conquest, But conquer for our liberties; and they Are lost by rashness. Let us rest our troops, . And think of Gellius on the morrow. 
Today, today,

CRIX.

Ere he have rallied this fight's fugitives.

SPART.

The thousands that are crowding to our lines Will, by the dawn, have trebled all his gain.

CRIX.

I will beat him with the Germans alone.

You shall not;

SPART.

I am your general, and forbid you.

CRIX.

I was a slave, but am not now.

Thracian,

Brother Crixus,

PHAS.

On second thoughts, 'tis better put this off, According as the general commands.

CRIX.

I am sole leader of my countrymen.

PHAS.

Sirrah, thou art a mutineer.-

SPART.

Peace, brother.-

\section{PHAS.}

Defy the general! If one beggar's rogue Of all his Germans dare to leave the lines, I'll have him spitted like a cur. 
SPART.

Peace, brother.

Contention will harm worse than this partition. German, thou hast thy wish: depart in peace, But without hope of succour, if the Roman Prevail above thee.

\section{PHAS.}

Pray the gods he do!

$<$ And thwack them till they are skinless, all.

Base rascals

And mutineers!>

SPART.

Take all thy countrymen,

Or all that wish to follow thee.

(Exit CRIXUs.)

PHAS.

Why did you let him go?

Rank mutiny!

\section{SPART.}

To teach him, brother,

Him and some others of our lieutenants, (For we are growing mad upon success,) An humbling lesson. A defeat were now Better than victory; and, in his Germans, We best can bear it.

PHAS.

Let them go, and hang; They are all villanous hotheads, and presumptuous 
Beyond all tolerance. And, to punish them, They shall not share with us the fame and spoil Of the sack'd city.

SPART.

Brother, I think thou art Almost as madbrained as the rest.

\section{PHAS.}

I have

A kind of ardour, that, for aught I know, May be a lunacy. But this is clear: Rome is a city; cities may be sack'd; So Rome may be.

SPART.

A city, that the world Looks frighted at, even in her sleep of peace, As gazers look at sleeping lions. I told This German fool, we did not fight for conquest, But for a passport to our several homes. What care we then to waste our vigour on The gates of fortressed cities?

\section{PHAS.}

But this city-

SPART.

Is as impregnable as the storm-arm'd sea. Why should we talk of it? Great Mithridates, Though populous Asia followed at his back, Should, were his frothy hopes to point at it, Be laughed at for a kingly maniac. 
What should be said of us, the mushroom warriors Of Roman dunghills, should our arrogance Mad us so far? I think, we do not fight To make the world talk?

\section{PHAS.}

I would have you do so;

Fight now for glory; let ambition raise you Among the deathless, now while fate invites you.

Rome has no greatness, but is now employed In foreign climes: You have well tried yourself; And consuls vanish, when your trumpet sounds. March on the city, and there swear to die, Or live its master, and you are its master. Think, brother, think what glorious fame were ours, As lasting as the eternal world, should we, The upturned dregs of servitude, destroy, As, by the inviting fates! We may destroy, This lair of lions, this den of conquerors, This womb of heroes, whose boastings fright the earth, And whose ambition (-look, Ambition!) -chains it!

\section{< SPART.}

This is a wild and most preposterous hope. Even the fierce Hannibal, with veteran troops, And all the towns of Italy at his feet, Save this alone, here paused his hopes.

\section{PHAS.}

T' excel the vaunted African, and dare Hope thou Beyond his daring. Hast thou not a heart Bigger than his, that, with a herd of slaves, Hast wrought as much as all his veterans? 
Smiles heaven upon thee less, which, in an hour, Has, from a dungeon, raised thee to an army, Still growing, still victorious? Do this deed, And live for ever. $>$

SPART.

Well, well, I'll think of it.

Perhaps Senona's there:-Ah, would to heaven, Phasarius,

I were with her now and my smiling boy, In Thrace again, beside our mountain cot, Or in those vales, where babbling Hebrus tumbles Along his golden sands; and dreamt no more Of sacks and battles.

\section{PHAS.}

Whilst this city stands,

This ne'er can be; for just so long our country Remains a Roman province. Tear it down, And you enfranchise Thrace, and half the world.

SPART.

We'll think of this again, when we are stronger, And when we have Senona sent to us.

Meanwhile we must the final effort make

To ransome her. <Did you secure a guide, To lead us through the mountains? I have seen The camp most strongly guarded, and fear not To trust it with the trusty Anomaiis.

When the tired troops have slept an hour, I'll order To bring them after us, to see indeed How we may end, what Crixus may begin, Disastrously for him, on Gellius, In the confusion of the Consul's triumph.> 
Pick me an hundred of our swiftest horses, And have them presently in wait for me. I shall fight better, when I know, each blow Strikes a protection for my family.

(Exeunt.)

SCENE III. A room in Crassus's Villa. Enter JULIA and FLORUS.

$$
\text { JUL. }
$$

I am glad to see thee. This terrific din Of the near battle made a sparrow of me. I was afeard to breathe, <lest I should swallow Some of your horrid missiles; for I ran Unto the housetop, to look on the fight. But the moon was more coward than myself, And hid her pale face in a cloud: so nothing I saw. But I could hear the brazen trumps, The conchs and cornets, the shouts and yells of fury, The clang of arms, and whistling in the air Of stones and arrows. But, come tell me now, My general, have you killed a foe tonight?

\section{FLOR.}

And won a civic crown, by saving a friend.

$$
\text { JUL. }
$$

That's good; I am glad to hear it. >

$$
\text { FLOR. }
$$

But I am sorry

To find you here among these fears and perils.

I would you were in Rome. 
JUL.

There is no peril.

Have you not beaten these wild gladiators? A shepherd flying from his pastures, told me, That Gellius had the victory, and had taken Or killed the insurgent, bloody Spartacus.

\section{FLOR.}

I know not that. 'Tis true, that we have beaten A band of mad rogues, that assaulted us; And 'tis believed, their general, Spartacus, Is dead upon our trenches; for whose body Search is now made. But one poor prisoner, $<$ I think, the only one whose life was spared, $>$ Declared these troops to be but a small band Of mutinous runagates, that had left their leader, Being thereto moved by their late victory Over the consul Lentulus.

JUL.

A victory over Lentulus?

What, Florus!

FLOR.

'Tis even so:

His army has been vanquished, himself slain By the late bondman. And those, who give faith To the assurance of our prisoner, Fear for our consul, should the Thracian march, After his mutineers, upon us now; Our camp being all a confused festival Of drunken triumph,- - half our soldiers scattered In search of spoil and fugitives.- 


\section{SPARTACUS (within)}

Guard the doors:

Let none go out.

FLOR.

What voice is that? By heaven,

We are betrayed!

(Enter Spartacus, Phasarius, and others. Anomairs.)

SPART.

$<$ Sold, lost, and dead!>-Look to the maiden.

$<$ What, flourishing fool, $>$ drop thy sword's point, or die.

FLOR.

A thousand times, ere thou, malicious rebel, Touch this endangered lady.

SPART.

Straw, I say!

(He disarms Florus.)

Know I not this boy's face? ${ }^{\text {I }}$

FLOR.

I think thou should'st. Spare thou the lady, rich will be her ransome. And for myself, I know, thy deadly fury Grants never quarter.

I There are the following notes in Bird's hand, evidently in answer to Forrest's suggested cuts.

"Think you had better keep these expressions particularly the flourishing fool and straw. They express, in a very lofty and furious style, the contempt which such a man as Spartacus would feel at finding himself resisted by a younker."

"The term boy's was meant as a substitute for boyish; not, as if asking the question of others, the face of this boy." 
SPART.

By the stripes not yet

Fled from mine outraged limbs, thou art the son Of Lentulus the scourger!

PHAS.

Ay, the same.

Let him atone his rascal father's sins:

Scourge him to death.

FLOR.

Give me a soldier's death:

Let me die by the sword. I never scourged thee.

SPART.

Thou! Miserable boy!

FLOR.

And well thou knowest, Thou fierce and fiendish man, this tongue of mine Was oft thy intercessor.

SPART.

I do know,

One of thyblood did give me to the scourge$\mathrm{Me}$, a free son of a free sire, and imaged After the semblance of the Only MasterGave me to thongs and whips, as a poor beast, Till I became one. This I know; know thou, From that shamed hour, when first my body writhed Under the merciless lash, I did devote 
The scourger and his household to the furies, To quick and murderous death. And thinkest thou, Thy whining kindness took away a pang?

Thou art the Roman's son, and thou shalt die.

\section{FLOR.}

Let it be so-

\section{SPART.}

It shall be so. Thou seest, Command and dignities have not wiped out The memory of wrongs; and Roman blood, Running in rivers ever at my feet, Sates not the thirst for more!-Take him away; Scourge him to death.

\section{JUL. (To Spart.)}

Thou horrible monster, spare him, And name whate'er thou wilt for ransome.

SPART.

Drachmas for stripes!

Ransome!

FLOR.

Beseech him not, fair Julia. Think of thyself, or let me think for thee.

JUL.

He never did thee hurt.

SPART.

Let her be ta'en away. 
FLOR.

Let her be ransomed, and for thine own wife.

SPART.

Ay, so I will: 'twas e'en for that I took her.

FLOR.

Then may'st thou instantly exchange them.-

SPART.

How!

FLOR.

Thy wife is in the consul's camp-

SPART.

In the consul's camp?

FLOR.

There driven by the fright of her conductors.

And thou may'st instant ransome her.-

SPART.

$\mathrm{Ha}$, ha!

Now does Jove smile. What, ransome her? Ay, ransome;

But with the steel.-I can almost forgive thee, For this good news.-Prætor, I have thee now

In the same trap thou set'dst for me!-What, sirrah, Ye have beaten my refractory lieutenant, The German Crixus?

FLOR.

Ay, I thank the gods. 
SPART.

And so do I; it wins me victory, And puts the second consul in my hands.Antistheus, see these captives safely guarded.Brother, the troops must now be nigh upon us.Take thou the Thracian cohorts, and in secret Steal to the heights that overhang his rear, Posting a strong guard on the river. Let none 'scape, And let none live. Myself will force the camp, And drive the rioting fools upon your swords.I say, spare none.

\section{PHAS.}

'Twere much too troublesome

To imitate them, and build crucifixes

For the prisoners.

SPART.

Let not a moment's rashness

Bring us a limping victory. Stand fast Upon your post, and every rogue is dead.Roman, thou shalt see how I'll ransome her!

(Exeunt)

SCENE IV. The Tent of Gellius, the Consul Gellius discovered, with Scropha, Senona and her child, and attendants.

\section{GEL.}

There is no doubt, this foolish German lies.

'Twas the main body of the rebels surely. No mere detachment would have impudence To march upon a consul. Now this victory, 
Which, on the morn, I'll follow up, will change The tone o' the angry Senate, and restore me To my full rank, and, what is better, send The scheming Crassus empty-handed back. This is a man should fight in the Velabrum, Among the cheating mongers, and not bring His brains of a broker to a glorious camp. This woman here, the wife o' the Gladiator, That cutthroat caitiff-

SENO.

Why dost thou slander him?

Has he not fought a consul?

GEL.

Pr'ythee, be silent.

He's a brave rebel, and will be renowned.-

Now, as I said, with this same woman here, The Greek-brained Crassus did design some trick, Some scurvy plot upon the Gladiator-

(Alarums.)

SCROPH.

Hark!

GEL.

A device of the rejoicing drunkards.This thing meant Crassus, this-

SCROPH.

The clang increases!

(A great shout is heard.) 
GEL.

The knaves are noisy.-

(Enter a CENTURIon, wounded.)

CENT.

Fly for your lives! The camp is forced-

GEL.

What camp?

CENT.

Your own. The Gladiators are upon us:

We are surprised, and all is lost.

(Exit.)

GEL.

What ho, my armour!

My armour!

(Exeunt all but SENONA and child.)

Enter SPa RTACUS, ÆNomaIIs, and Gladiators.

$$
\text { SPART. }{ }^{1}
$$

\section{Victory! Ha! ha!}

Romans are sheep-search every tent-ah! Jove!

I have found ye wife, aye, and have ransomed ye. What did you think I had deserted you?

I have followed the reading probably suggested by Forrest. The original lines, crossed out in the MS., are:

"Victory! ha, ha.

Romans are sheep.-Search every tent-Ah, Jove!

I have found ye, wife, and in a noble hour.

When we met last, I was a slave; and now, In a consul's camp, I stand a conqueror! 
378 DRAMATIC WORKS OF ROBERT BIRD

Look, I have found you in a noble hour: When last we met I was a slave: and now In a Consul's camp I stand a conqueror!

(Curtain.)

END OF ACT III. 


\section{ACT IV}

< SCENE I. ${ }^{\mathrm{x}}$ The Camp of Crassus. Enter Crassus, Mummius, Jovius, lentulus, Bracchius, and Attendants.

\section{CRASS.}

And Gellius beaten too? both consuls beaten? This is some demigod that hath ta'en man's shape, To whip us for our sins.-Both consuls beaten? I would I had those Macedonian legions.

$$
\text { Jov. }
$$

Have them thou shalt; ay, and the Spanish too: The senate, in their terror, (for the victories Of this great savage now add fright to shame,) Bid Pompey and Lucullus, with their troops, Instant embark for Rome.

\section{CRASS.}

Why should they send For Pompey too?-Perhaps it may be better.See that the fugitives from the consular camps Be decimated, and so punished. The cowards should Be slain by duplates rather than by tithes:

I'll make example of them.-Jovius,

x This scene is struck out in the MS. and, according to a note in Bird's handwriting, was "omitted in the representation." 
Lay not this consul near my villa? I would not My niece should come to harm; and it is horrid To think her in the hands of the barbarians.

Jov.

I am sorry, prætor-

CRASS.

What, man, is it so?

Jov.

A herdsman, fled that night from the estate, Just on the eve of battle, saw the house Beset by numerous slaves.-

CRASS.

The gods be with her:

I loved her well.-Sirrah, where is that woman, I bade thee bring me?

But on the road.

\section{LENT.}

Not yet reached the camp,

CRASS.

Let her be hastened hither.

I did intend to use her as a check

On the uxorious chief. Now shall she ransome My Julia from him.-Where lies the enemy?

Jov.

$\mathrm{He}$ is advancing on us.

CRASS.

What, advancing? 
Jov.

With countless multitudes at his heels.-

CRASS.

Intrench, intrench.

What! come,

Jov.

Rather march out to meet him.

Shall it be said, that Crassus, the lieutenant

Of valiant Sylla, hid behind a trench,

When bondmen menaced him?

CRASS.

Shall it be said,

Crassus, the prætor, like a hair-brained fool, Helped these same bondmen to a victory?

Spear me these cowards; and intrench, I say.What, sirrah?

(Enter a Messenger, who speaks with Jovius.)

Jov.

Happy tidings! Marcus Lucullus

Hath landed his army at Brundisium;-

CRASS.

The gods be thank'd.-

At Ostia.

Jov.

And legion'd Pompey too 


\section{CRASS.}

Still thanks. Let messengers

Be sent o' the instant to both generals, Praying them, as they love the gods and Rome, Their march to hasten.

(Exit Messenger.)

Good centurion,

I will employ thee in a difficult office,

Wherein thou may'st the state and me do service.

$$
\text { Jov. }
$$

Let it be honest then and soldier-like.

\section{CRASS.}

So it shall be. I'll have thee an ambassador To this mad Thracian, to propose a ransome For my unhappy niece, if niece I have; Or to exchange for her his wife and brat, Now in our hands. If she be living, have her At any ransome; stick not at the sum.And hark ye, use your eyes and wisdom well. Look me out, as a soldier, what 'twould profit A soldier to have known; and if thou find'st A man among his officers to be bribed To any treason may advantage us, Make him what gain thou wilt.-But see thou bring My Julia with thee.-If thou find'st a man, That may be bought, at any price, to murder The Thracian, buy him for that act.

$$
\text { Jov. }
$$

\section{Not I:}

No foul and dastard blows i' the back. 


\section{CRASS.}

For honest enemies; but felon foes

Ay, none E'en crush feloniously.-Away: heaven speed thee. Kill we the chief, and I will end the war, Ere Pompey comes to share with me the honour.

(Exeunt.) 


\section{ACT IV}

SCENE I. The Camp of Spartacus. Enter Senona, Julia, Florus, and Fenomais.

SENO.

Weep not, poor lady.-

JUL.

Why bid'st thou me not weep?

Hadst thou no tears, when thou didst find thyself The slave of strangers? Yes, thou hadst, although In bond of the merciful, who were never used To aught but gentleness with woman. Yet me, The lily-cradled daughter of great nobles, Brought to the slavish ${ }^{\mathrm{I}}$ thrall of slaves, exposed To all their brutal cruelty, thou bid'st To weep no more.

SENO.

It is thy fright, that conjures These shapes of danger. Thou art here as safe As woman may be in a troubled camp.

Thou art no slave; but, I am sure, art held To timely ransome. Pray be comforted:I know, thou art safe.

× There is a query in Bird's hand,--"Shall I substitute vile, odious, degrading, or some other word?" 


\section{JUL.}

I have, I know, that safety

That may be found in den of wolves or bears.Would I had died or e'er my fate had thrust me Among these dreadful murderers.

SENO.

They are such

To none my husband favours.

$$
\text { JUL. }
$$

Is not he

As fierce and pitiless as the rest, who seeks

To venge his wrongs upon the innocent?

He that has madly doomed that hapless captive His father's crime in blood to expiate?

SENO.

He has not doomed him; nay, if he said so, It was in wrath; and he will pardon him. The heart that throbs beneath his bloody mail, Can melt to pity quickly as thine own. I think, he'll free him; for thyself, I know, Thou art protected.

JUL.

Am I from his brother, The insolent Phasarius?-Heard I not What claim that villain made to me? Alas, Thou art a woman, and can pity me.

SENO.

Thine ears deceived thee; did they not, Enomaiis? 
ÆNO.

I think so, lady.

SENO.

Did not this argument

Point to some claim of war?

ÆNO.

A bold proposal

Made by Phasarius, by the chief denied:

This was their argument.

(Enter Spartacus.)

JUL.

Alas, behold

How frowns the angry fury on his face!

Bodes this no ill to Florus or to me?

SENO.

What is the matter, husband, that you look So sad and heavy?

SPART.

Sad and heavy, am I?-

(Aside.) And shall I, for this face of snow provoke A threatening ruin? Out of foolish pity For one that loves me not, drive from my heart, The heart that loves me well?

SENO.

What say'st thou, Spartacus? 
SPART.

(Aside.) To save her girlish body from the shame, Her baby bosom from the pang,- - to rescue From a short dream of sorrow, one young fool Out of the million millions of the mourning, Kill mine own coming glory and the hopes Of a wrong'd world?

SENO.

I fear me, thou art angry.

SPART.

Hark ye, my girl-that fool that trembles yonder-

SENO.

I pity her.

SPART.

Dost thou indeed? And art thou Assured she is worth thy pity? Were the world A jot the worse, were she removed from it?

SENO.

Alas, you will not harm her? She has indeed A kind and foolish heart.

SPART.

Has she indeed?

Well, she shall to her father.

SENO.

She has none. 
SPART.

What, wife, an orphan? Now the incensed heaven Smite my hard heart! A poor and feeble child Left struggling fatherless in the world, and I Consent to wrong her!

SENO.

What is't you say?

SPART.

Not I,

Though forty thousand unjust brothers storm'd.One day mine own child will be fatherless.We'll ransome her.

SENO.

I'm glad to hear you say so.

SPART. (To JUlia.)

What, foolish maid, why dost thou weep? Come, smile,

I'll send thee to the prætor-and the boy too.-

I think 'twould break her heart to kill him.-

(Enter Phasarius.)

Brother, I hope thou hast forgot this folly.

Brother-

\section{PHAS.}

I claim the captive.

SPART.

Thou shalt have a thousand;

But not these twain. 
PHAS.

I care not for the boy.

The girl is mine,- captured by mine own hands;

Therefore mine own.

FLOR.

Base caitiff!

SPART.

Sirrah, begone.-

PHAS.

Deny me her, and, by the fates, thou art

No longer brother of mine. 'Twas I that helped thee To this high station; and the troops thou rulest, Are but my lending; for that hour I leave thee, They leave thee to.

SPART.

Come,-look me in the face, And let me see how bad desires have changed thee.

PHAS.

I claim the captive.

SPART.

Set thine eye on her:

Lo you, she weeps, and she is fatherless. Thou wouldst not harm an orphan? What, I say, Art thou, whom I have carried in my arms To mountain-tops, to worship the great God, Art thou a man to plot a wrong and sorrow (And thou a man!) against a feeble orphan? Wilt thou now ask her? 


\section{PHAS.}

Ay.

SPART.

Thou art a changeling!

My father ne'er begot so base a heart.Brother, I do conjure thee, for I love thee, Forget this thing.

PHAS.

Farewell.

SPART.

Thou wilt not go?

PHAS.

Ay, by great Jove, I will. Play thou the tyrant On those that follow thee.

SPART.

My younger brother:-

Nay, I'll not call thee such,--but a hot fool And heartless enemy.-

PHAS.

Call what thou wilt:

I am a man not to be mock'd and wrong'd, Nor flouted in my counsels. I did ask you, Now that you had the wind of the fooled prætor, Now when rich Rome is emptied by her levies, Now when the eager troops cry all, for Rome, To march upon it, ere the joining armies Of Pompey and Lucullus should prevent you. 
This I did ask, and this you did deny, Though, by a former promise, pledged thereto.

SPART.

I promised not.

\section{PHAS.}

By heaven, you did-when stronger.

This you refuse; and when, forgiving this, I ask my captive, you deny me her, With many a sharp and contumelious word, Such as is fitter for a dog than me.

\section{SPART.}

Forgive me, if my anger used such shame; I knew not what I said.

PHAS.

March then to Rome.

\section{SPART.}

It cannot be. We should but set us down Under her walls, where the three generals, Ere we could force the gates, would hedge us in. We cannot stand against them all even here; But, when in Sicily, are invincible.

PHAS.

Rome, or the captive: no more Sicily.

SPART.

To Sicily:

There, by the ocean fenced, rouse up and gather The remnants of those tribes by Rome destroyed, 
Invited to their vengeance. Then will come, Arm'd with retributive and murderous hate, The sons of fiery Afric,-Carthaginians

Out of their caves, Numidians from their deserts;

The Gaul, the Spaniard, the Sardinian;

The hordes of Thessaly, Thrace, and Macedon, And swarming Asia;-all at last assembled In vengeful union 'gainst this hell of Rome. Then may we crush, but now we crush ourselves. Let us to Sicily.

\section{PHAS.}

Those that will. Farewell.

\section{SPART.}

Will you desert me?

PHAS.

I did think thee meant

For the most godlike enterprise of earth:

Thou fail'st. Farewell; protect thyself.

SPART.

Remember Crixus.

Mad boy,

PHAS.

And his thousand Germans!

I go with Gauls and Thracians, and fifty thousand.A Roman girl was worth this coil!-Farewell: Learn to be juster. 
SPART.

Gone! Alas, alas,

Am I unjust? I did not think my brother Could e'er desert me.

ÆNO.

Spartacus-

SPART.

Anomaiis,

Dost thou remain? Why dost thou stay with me?

ÆNO.

For that I know thee wiser than thy brother.

I will stand, fight, or die with thee. But look;

If thou speak not, the army to a man,

Will follow this young madman.

SPART.

Mad and ungrateful all! Will none remain?

SENO.

Beseech you, speak with them, my honoured husband.

SPART.

And he endanger'd thee too! By the heavens,

I'll ne'er forgive him.-Nay, go to your couch.

I'll speak with them. They will not all desert me.

(Exeunt.) 
SCENE II. The Camp of CRASSUS. Enter Crassus and LENTULUS.

CRASS.

Thy son was kill'd then? I am sorry for him.

I heard, he bore him soldier-like, and I, Upon this promise, did intend him favour.

LENT.

I know not that he certainly was killed; But, I thank Jove, he did not fly his post.

\section{Enter BracchIUS.}

CRASS.

What of the enemy? does he still approach?

BRAC.

No, he is flying.

LENT.

Flying! thou art mad.

BRAC.

That may be, for my slaves have ruined me. Why should brains stick where gold will not?

CRASS.

Come, sirrah,

What didst thou mean by saying the foe fled? $<$ How flies he? 
BRAC.

As a hound, that having coursed

A stinking brock, upon a sudden turns, To chase a noble stag.-Ourselves the badger, And Rome the worthier quarry.

\section{CRASS.}

What dost thou mean?

$$
\text { Tedious fool, }>
$$

BRAC.

That the fierce Gladiators

Instead of dinging us, as seemed designed, Are now upon the highway to the city.

\section{CRASS.}

To Rome?

BRAC.

Yes, flying to Rome.

\section{CRASS.}

Presumptuous fools!

$<$ Now may we build a forest of crucifixes. Bid the men cast away their picks, and arm. $>$ We'll after them.

BRAC.

I think there's some division Among the leaders; for the herds afoot, March in disorder. 


\section{CRASS.}

Separated! Jove,

I thank thee for this boon.-Another Crixus!

To arms, I say. Send out the cavalry,

$<$ To gain their flanks and front, letting them get

Beyond the leader's camp. >-This is a triumph.To arms, I say.

(Exeunt.)

SCENE III. The Camp of Spartacus. Enter SPARTACUS and ANOMAIIs.

\section{SPART.}

Seven thousand true? A handful, but enough, Being staunch and prudent, for the enterprise.Desert me! Well, well, well.-Among the hills Are many paths that may be safely trod; Whereby we'll gain the sea, and so pass o'er To safer Sicily.-Perhaps I spoke Too roughly,- but no matter.-Did you send To hire the shipping of those pirates? Well.And all prepared to march at nightfall?-AEnomaiis, Do you not think they'll beat him?

ÆNO.

I doubt it not;

Phasarius being a soldier, but no leader.

$$
<\text { SPART. }
$$

An excellent leader, but that he is rash.

ÆNO.

That is the misery. He will fight you hotly An army of lions; but a troop of foxes 
May easily beat him. Now the prætor's brain Is all o' the fox's colour. $>$

SPART.

Well, I care not:

We will to Rhegium.-Think you, Ænomaiis, I might not, while the prætor steals upon him, Steal on the prætor, and so save the army? What say'st thou?

ÆNO.

Hang them, no. This brings Lucullus On our seven thousand. Let the mutineers Look to themselves.

SPART.

Right, very right, right, Enomaiis.

Let them look to themselves. He did desert me;

My father's son deserted me, and left me

Circled by foes. I say, 'tis very right.

$<$ He shall no help from me; not though they beat him

An hundred times; no, no, no help from me.>

ENO.

Lo you, a messenger!

Perhaps he is sorry.-

SPART.

From Phasarius!-

Enter Jovius. 
ENO.

From Crassus.

Chief, an embassy

SPART.

And what would Crassus with the Gladiator, The poor base slave, and fugitive, Spartacus?

Speak, Roman: wherefore does thy master send Thy gray hairs to the cutthroat's camp?

Jov.

Brave rebel,-

SPART.

Why that's a better name than a rogue or bondman; But, in this camp, I am call'd general.

Jov.

Brave general; for, though a rogue and bondman, As you have said, I'll still allow you general, As he that beats a consul surely is,- -

\section{SPART.}

Say two,- -two consuls; and to that e'en add A proconsul, three prætors, and some generals.

Jov.

Why 'tis no more than true.-Are you a Thracian?

Ay.

$$
\text { SPART. }
$$

Jov.

There is something in the air of Thrace Breeds valour up as rank as grass. 'Tis pity You are a barbarian. 
SPART.

Wherefore?

Jov.

Had you been born

A Roman, you had won by this a triumph.

\section{SPART.}

I thank the gods I am barbarian;

For I can better teach the grace-begot

And heaven-supported masters of the earth,

How a mere dweller of a desert rock

Can bow their crown'd heads to his chariot wheels.

Man is heaven's work, and beggar's brats may 'herit

A soul to mount them up the steeps of fortune,

With regal necks to be their stepping-blocks.-

But come, what is thy message?

$$
\text { Jov. }
$$

$\mathrm{O}^{\prime}$ the prætor, is thy captive.

$$
\text { Julia, niece }
$$

SPART.

Ay.

Jov.

For whom

Is offered in exchange thy wife, Senona, And thy young boy.

SPART.

Tell thou the prætor, Roman, The Thracian's wife is ransomed. 
Jov.

How is that?

SPART.

What ho, Senona!

(SENONA appears with the child at a tent door.)

Lo, she stands before you, Ransomed, and by the steel, from out the camp Of slaughtered Gellius.

(Exit Senona.)

Jov.

This is sorcery!-

But name a ransome for the general's niece.

SPART.

Have I not now the prætor on the hip? He would, in his extremity, have made My wife his buckler of defence; perhaps Have doomed her to the scourge! But this is Roman. Now the barbarian is instructed. Look, I hold the prætor by the heart; and he Shall feel how tightly grip barbarian fingers.

$$
\text { Jov. }
$$

Men do not war on women. Name her ransome.

SPART.

Men do not war on women! Look you:

One day I clomb upon the ridgy top Of the cloud-piercing Hæmus, where, among The eagles and the thunders, from that height, I look'd upon the world-or, far as where, 
Wrestling with storms, the gloomy Euxine chafed On his recoiling shores; and where dim Adria In her blue bosom quenched the fiery sphere. Between those surges lay a land, might once Have served for paradise, but Rome had made it A Tartarus.-In my green youth I look'd From the same frosty peak, where now I stood, And then beheld the glory of those lands, Where peace was tinkling on the shepherd's bell And singing with the reapers; $<$ or beneath The shade of thatch eaves, smiled with grey old men, And with their children laughed along the green. $>$ Since that glad day, Rome's conquerors had past With withering armies there, and all was changed: Peace had departed; howling war was there, Cheered on by Roman hunters: then, methought, Even as I looked upon the altered scene, Groans echoed through the valleys, through which ran Rivers of blood, like smoking Phlegethons; Fires flashed from burning villages, and famine Shriek'd in the empty cornfields. Women and children, Robb'd of their sires and husbands, left to starveThese were the dwellers of the land!-Say'st thou Rome wars not then on women?

Jov.

This is not to the matter.

\section{SPART.}

Now, by Jove,

It is. These things do Romans. But the earth Is sick of conquerors. There is not a man, Not Roman, but is Rome's extremest foe; 
And such am I, sworn from that hour I saw These sights of horror, while the gods support me, To wreak on Rome such havock as Rome wreaks, Carnage and devastation, wo and ruin. Why should I ransome, when I swear to slay?Begone: this is my answer!

$$
<\text { Jov. }
$$

With your leave

This prattling scares no Romans; and these threats Come weakly from a chief of mutineers.

$$
\text { SPART. }
$$

Of mutineers?

$$
\text { Jov. }
$$

Ay, marry, 'tis well known, Your cutthroats have deserted you. Content you, Crassus will punish the foul traitors.

$$
\text { SPART. }
$$

\section{Crassus!}

$$
\text { Jov. }
$$

Ay, Crassus.-Hercules, how men will talk! Wreak wo on Rome!-I tell you, your lieutenant Will hang upon a cross before the morrow. So name your ransome, while 'tis offered you.

$$
\text { SPART. }
$$

Begone, I say. 
Should we not strike now? Now while we might fall Upon their rear, and take them by surprise?

\section{ÆNO.}

Let them be punished, castigated well, And they'll return to wisdom and obedience.

\section{SPART.}

Right, right. Let them be punished, hack'd to the bones:

This will speak better than my words. Prepare For Rhegium. He'll return to us tomorrow.

$($ Exeunt.) $>$

END OF ACT IV. 


\section{$\operatorname{ACT} \mathrm{V}$}

SCENE I. The Peninsula of Rhegrum. The Camp of the Gladiators. Enter SPARTACUS and ENOMAIIs.

\section{SPART.}

Routed and cut to pieces!-Said I not?

Did I not tell them?-Utterly destroyed!

Scattered like chaff! -Now by the eternal fates, They did provoke high heaven, deserting me.How many slain?

ÆNO.

Indeed it is not known.

SPART.

Many, I'm glad; I should be very glad:

Did I not lead them ever on to victory?

And did they not forsake me? Wretched fools, This was my vengeance, yea, my best of vengeance, To leave them to themselves, that Roman prætors Might whip them for me. Art thou not rejoiced? Art thou not, Anomaiis, glad of this?

Glad, very glad?

<ÆNO.

I shall be, when I see

Half of them back again. 
SPART.

I'll decimate them:

Even as the Romans punish, so I'll punish.Ruin me all these grand and glorious hopes?

Nay they were certainties.-An excellent army, That might have fought with Pompey, broke and ruined

By their mad mutiny! An excellent army-

ÆNO.

Indeed, an excellent.

SPART.

Foolish Anomaiis,

Why did'st thou stay me, when I would have saved them?

ÆNO.

Had this been well? Had their ingratitude Deserved it of thee?

SPART.

Ay, ingratitude.

Did I oppress them? Did I tyrannise? >

ÆNO.

'Tis rumoured that Phasarius fell.

SPART.

My brother,

My foolish brother-why did he part from me?Nay, I'll not mourn him. 
ENO.

This evil news must now

Hasten our embarkation. The pirate ships Already are launching from the shore.

\section{SPART.}

Why now

You are too fast. Bid them be beached again.$<$ Alas, that foolish boy! We'll rest awhile, And see what fugitives may come to us. $>$ Art sure Phasarius was slain?-the pride Of his dead mother's heart; and, I do know, Though prone to anger, of a loving spirit.We'll rest awhile here on this promontory.

ÆNO.

Each moment has a peril. For these pirates They are most treacherous hounds, and may set sail Without us; and the prætor, thou know'st well, Is trenching us in on this peninsula.

\section{SPART.}

What care I for the prætor and his trenches?

< This is a boy's trick, and a boy might meet it.> Trenches to stop a Thracian!-Look you now What drooping slave is that? By all the gods, It is my brother!-But I'll not be glad. Lo you, how humbled, spiritless he looks! Where are his troops?

\section{(Enter Phasarius.)}

Sirrah, why comest thou here? Didst thou not part from me, and take mine army? 
Did'st thou not teach my followers mutiny, And lead them to destruction? Thou whipp'd fool, Why comest thou here?

PHAS.

To ask thy pardon, and to die.

SPART.

Couldst thou not die with those thou led'st to death, That men, who after should have called thee madman, Might not have called thee craven?

\section{PHAS.}

I am no craven;

A wretch, I grant you, but no craven.

\section{SPART.}

Where are thy troops? that throng'd and valiant army

Thou stol'dst from me?

I am alone of all.

\section{PHAS.}

With Pluto. Why demand me?

SPART.

Most wretched man,

Thou hast murder'd fifty thousand men, destroyed Thy brother and thy country, and all hope Of the earth's disenthralment.

\section{PHAS.}

My brother, that's enough. 
SPART.

Ay, look, behold;

But yestermorn, I was a conqueror,

On the high verge and pinnacle of renown;

Today a skulking, trembling, despised man,

Thrust in a pit. Whose traitorous hand was it,

Pluck'd me from my high seat, and sunk so low?

Who did this thing, this foul, felonious thing?

\section{PHAS.}

Myself, that was thy brother.

SPART.

Ay, that was!

PHAS.

Why shouldst thou stab me with thy words? O brother,

Strike me with thy sharp sword, but speak no more:

Give me to punishment, or drive me forth

To die by Romans; but upbraid no more.

SPART.

Shall I forgive him? Look, he is penitent.

ÆNO.

But he has lost them all.

SPART.

Ay, so he has.-

Ask'st thou for pardon, when thou hast slain all?

Away! thou didst discard me from thy heart:

I banish thee from mine. 
PHAS.

It is but just.

Why should I live, when I have ruined thee?

I should have died before. Farewell.

SPART.

Come back:

I will forgive thee: nay, I have.-O brother, Why didst thou do this wrong? But I'll forget it.Let the ships now be launched, now, Anomaiis; Now cross to Sicily.

(Exit AnomaIrs.)

With these fifty thousand-

But I've forgot it.-What, were all destroyed?

All, all.

\section{PHAS.}

SPART.

A disciplined army!-But no matter.All slain upon the field?

PHAS.

Six thousand wretches

Yielded them prisoners to the prætor.

\section{SPART.}

\section{Well,}

He took six thousand prisoners. These will now Suffer a double wretchedness.

\section{PHAS.}

They will not.

Never fear it: 
SPART.

How is that, Phasarius?

Did not the prætor, in his proclamations, Threat us with bondmen's deaths by crucifixion?

PHAS.

And he will keep his word-nay, he has kept it.

What!

$$
\text { SPART. }
$$

PHAS.

Are men beasts, that life should count no more Than a beast's sob?

SPART.

Thou fill'st my soul with terror.

Are they condemned? All?

PHAS.

Executed.

SPART.

Six thousand men, and crucified!

Horror!

\section{PHAS.}

\section{Crucified.}

I saw a sight last night, that turned my brain, And set my comrade mad. The Roman highway Is, each side, lined with crosses, and on each cross Is nailed a gladiator.-Well, 'twas night, When, with a single follower, I did creep Through the trenched army to that road, and saw 
The executed multitude uplifted

Upon the horrid engines. Many lived:

Some moaned and writhed in stupid agony;

Some howled, and prayed for death, and cursed the gods;

Some turned to lunatics, and laughed at horror;

And some with fierce and hellish strength, had torn

Their arms free from the beams, and so had died,

Grasping, headlong, at air. And, oh the yells,

That rose upon the gusty sighs of night,

And babbled hideously along the skies,

As they were fill'd with murder!

SPART.

Say no more:

This is too dreadful for man's ear. I swear

For this to make Rome howl. What, AEnomaiis.

Are the ships all afloat?

(Reënter ÆNomaIIs.)

ÆNO.

And gone.

SPART.

What, gone?

ÆNO.

These same perfidious pirates, with their hire, Have set their sails, and fled.

SPART.

The ocean god

Meet them with hurricanes, sink their ships, and feed Sea-monsters with their corses! 
ÆNO.

All is finished:

This is the fruit of mercy for deserters.

$$
\text { SPART. }
$$

Be that forgot.

ÆNO.

What now remains for us,

But to sit down and die?

SPART.

I'll tell thee, what:

To fight the prætor.

ÆNO.

Though his troops outnumber

Ten times our own!

SPART.

Ay; our despair will make us

Each ten times stronger than his foe. Fill up This schoolboy ditch with disregarded plunder, And when the watchdogs sleep, like wolves, steal on them

And take them by the throat. I have no fear, But we shall find a pathway through their camp. Then to Tarentum; there we'll find us ships. Or, if that fail, with a despairing fury, Turn upon Rome, and perish there.

\section{(Enter SenONA, with the child.)}

What now?

Com'st thou to mourn o'er our mishaps, Senona? Be not dismayed: I'll find thee safety yet. 
SENO.

Thou wouldst conceal these newer perils from me; But well I know, that every hour now brings A menacing cloud about thee.

SPART.

Clouds, ay, clouds:

A cloud is on my path, but my ambition Sees glory in't: as travellers who stand On mountains, view upon some neighbouring peak, Among the mists, a figure of themselves, Traced in sublimer characters; so I Here see the vapory image of myself, Distant and dim, but giantlike-I'll make These perils glories.

SENO.

And the ships have left thee?

SPART.

Thou art a soldier's wife, and wilt not tremble To share his danger. Look, through yonder camp Our path lies.

\section{SENO.}

I will walk it by thy side.

SPART.

Not so; for though unharmed by steel, the sight Of the near fray would kill thee. I have discovered A path almost unguarded; where, whilst I Assault the Roman in his sleep, thyself And my war-cradled boy, with my Phasarius To guard thee, shall in safety pass, and join me After the battle. 


\section{DRAMATIC WORKS OF ROBERT BIRD}

SENO.

Why not lead your army

By that unguarded path?

\section{SPART.}

Trust me, dear wife,

I'll make it such for thee, but cannot have it Safe for an army. The surprised distraction Of the attack will call the guards away. This is the safest.

SENO.

Let me go with thee.

I do not fear the horrors of the storm.

SPART.

It cannot be. What, brother-

\section{PHAS.}

Let some one else

Be made her guard; while I, in fight, find vengeance, And reparation of my faults.

\section{SPART.}

Refuse me this, Phasarius?

Wilt thou

PHAS.

Am not I

A rash and witless fool? Trust not to me What thou so valuest. 
SENO.

I beseech you, hear him.

Let me not leave you, Spartacus: my heart

Is full of dismal and of ominous fear,

If I do leave you now, I leave for ever.

If I must die, let me die where thou art.

SPART.

Why talk'st thou now of death? I say, I'll make This path most safe for thee. How could I fight, Or play the leader in a bloody storm, With thy pale visage ever in my eye?

\section{PHAS.}

I do beseech you, make not me her guard.

SPART.

It must be so. And hear me now, Phasarius;

I put into thy hands more than my soul:See, my dear wife, and here my innocent boy.These are the very jewels of my heart.

Protect them for me. Be not rash; steal softly, With the small faithful troop I'll send with thee, Through glens and woods; and when the alarm is sounded,

March fast but wisely. For thy life, and mine, Avoid all contest, shouldst thou meet a foe;

Nay, though thou know'st thou hast advantage, fight not.

Join me, with these in safety, and assure me No man has drawn his sword.-And now farewell. 
Farewell, Senona: I pray you do not speak.Thou art very safe. Farewell.

(Exeunt Senona, child, and Phasarius.)

ÆNO.

$\mathrm{He}$ is too rash.

SPART.

Rash, had I given him a command in battle; But will not be with them.-Rouse up the troops. Fill up the ditch with baggage, as I told thee.< I'll see that all be schooled for this assault. >

(Exeunt.)

SCENE II. Before the tent of Crassus. Enter Crassus, Mummius, Jovius, Lentulus and BracCHIUS.

\section{CRASS.}

Now I lament me, on this overthrow Of the chief army of the enemy, I prayed for Pompey and Lucullus. If I end not instant, by another blow, The war I have so maimed, comes me a colleague To chouse me of my triumphs.

Jov.

You must be quick then. The dawn will show you Pompey by your side; Or rather, dashing with a Roman scorn, Amongst the ruffians you have trapp'd. 
CRASS.

I think,

Ourselves may do it.-And this hell-dog holds The girl to doom?

Jov.

He says, he is instructed

By your fore-thought intentions with his spouse.

CRASS.

But dost thou think he'll slay her?

Jov.

May purchase mercy with her.

Not while he

CRASS.

Shall I take her

Out of his camp by force? or send thee back, To offer mercy and receive submission?

Jov.

Propose him life and liberty, and make him A Roman citizen.

\author{
CRASS. \\ What, a rebel slave!
}

Jov.

In these rough, rotten times, we do not scruple To raise our rogues to honour. Why then blush, To anoint a slave, that's capable and honest? 
The genius of this Thracian, had it been In honourable trust display'd, had quell'd A score of barbarous nations; and may yet, Make but the man a Roman.

CRASS.

We will make him A captive first.-Were my poor Julia free!(Loud alarums.)

What is the matter?

Jov.

The rats are out! By Jove, The slaves have pass'd the trenches, and assault us!

CRASS.

Thou art mad! They dare not-What, to arms, to arms!

Nay, if they will, let them into the camp, But let not out.-To arms, to arms!

(Exeunt.)

SCENE III. Another part of the Roman Camp. Enter Crassus, Jovius, Mummius, and Lentulus.

\section{CRASS.}

Mischiefs and plagues, and slavish stripes disgrace These shameless cowards! What, ope their ranks, and give

A path to these few madmen! Let them scape us!

Jov.

Nay, they are gone, that's certain,- - but will drop Into the jaws of Pompey. 
CRASS.

Follow them.

Bid the legions

Jov.

When the day breaks; but not now.

CRASS.

Shall I let Pompey take them, and have Rome Laugh at my shame? Have Pompey join the scorners, And mock me too? Hie thee away, good Jovius; Follow the Thracian; offer pardon, freedom, Whate'er thou wilt. Do but delay his march: Let him not come near Pompey-Quick, away!

(Exeunt.)

SCENE IV. The Camp of Spartacus, among the hills. Enter Spartacus and ANomaIIs.

SPART.

Was not this well? When desperate men contend, The brave will fly from them. To fight for life, Fights surest for a victory. Fought we well? I would not give these seven thousand poor rogues, For a whole herd of angry Gauls. We'll win The highway to Tarentum yet.-Lieutenant, Should they not now be here?

ÆNO.

Who?

SPART.

Who! Phasarius And his care-chosen guard-my brother and my wife. 
ANO.

They tread a rough and tangled path.

SPART.

'Tis true;

And finding there more guards than I had word of, Their caution journeys them the slower. I Am almost grieved, I brought them not with me.How fare the captives? Bring me to Tarentum, I'll send that girl unransomed to the prætor.Would they were here!-Bring in the prisoner, And find how march the coming generals.

(BRACCHIUS is brought in, guarded.)

ÆNO.

This fellow was the master of thy brother. Question him, and then hang him, for a baser, More heartless master never yet struck slave.

\section{SPART.}

I am sick of blood.-Is not the sun yet up? If they be seen-but I'll not think of that.Be not afeard: hadst thou been worth a blow, I had not spared thee. Speak, and truly speak, Or thou shalt fat the kites: When looks the prætor For Pompey and his Spanish troops?

BRAC.

Not for, but at him.

He looks

SPART.

Wretch 
BRAC.

And so may'st thou,

Yonder among the heights upon thy left.

\section{SPART.}

Wretch, if thou mock me, I will strike thee dead. Know I not well the prætor's craft? These eagles That spread their golden pinions on the hills, Were wing'd by Crassus thither, to affright me. Are they not Crassus's standards? Own me that, Or look tonight to sup in Acheron.

\section{BRAC.}

To sup on earth, then, I'll agree to this; But I shall lie.

SPART.

Rogue, answer me again:

Are those troops Pompey's.

BRAC.

$$
\text { Ay. }
$$

SPART.

The gods forbid!

They are in motion too! Now I begin To feel my desolation, and despair. What, Enomaiis, send me out a scout To view those hill-perched foes, and quick prepare The army for the march. And my poor wife! Why did I trust her with Phasarius?

< Send out a cunning guide to hunt the path.>

(Exit Ænomairs.) 
Roman, if thou speak false, I'll have thee slain.Where rests Lucullus?

BRAC.

In no place he rests, Save nightly on the highroad from Tarentum.

$$
<\text { SPART. }
$$

Villain, thou liest! The gods have not so left me. I say, thou speak'st not true.

BRAC.

Well, I speak false;

But notwithstanding, he is on that road.These are the bloodiest cutthroats! $->$

SPART.

Now, out on me,

My heart is full of fear. The prætor on my rear, Lucullus, Pompey on my front and left, And naught but howling seas upon my right! Seven thousand men against an hundred thousand! If Crassus love the girl- $\mathrm{He}$ fears disgrace'Tis not infeasible-unless, alas, My wife, perchance, be faln into his hands; Then can the maiden buy me naught but her.

(Reenter ÆNomaIIs, with Jovius.)

ENO.

The Roman prætor

Sends thee again an envoy. 
SPART.

Speak, centurion;

What word sends Crassus?

Jov.

For the Roman lady,

A princely ransome; for thyself, an offer

Of mercy, pardon, Roman denization,

And martial honour and command; provided-

SPART.

Ay, provided!

Jov.

Thou instantly, ere Pompey leave the hills, Surrender up these malefactious slaves

To whips and crosses. Therefore, most valiant Thracian,

Put by the frenzy, that would fight against

Three circling armies, and accept this boon

Generous and great.

\section{SPART.}

I am unfortunate,

Thou know'st that well; but not being Roman yet,

I scorn the foul condition, that makes me

To my true friends a traitor. Give them freedom, And they lay down their arms; but talk of crosses, And they have yet the arms that cut a path Through the proud prætor's camp.

$$
\text { Jov. }
$$

Why shouldst thou care,

Thou, who hast such a Roman soul, for these 
Vile runagate rogues, who, at an opportunity, Thee would betray as freely as their masters? Let them be hanged, and be thou made a Roman. Perhaps thy word may save the least offending; But let the scum be punished.

SPART.

They shall die,

Like soldiers, on the field, or live in freedom. But hearken, Roman:

I know the prætor, that he loves his niece, But honour more; I know, if Pompey strike At me one blow, the honour all is his, And nothing left for Crassus, but comparison Betwixt what Pompey does, and what he could not. He will not then have Pompey strike me, and He would have back his niece. While I lie here On this impregnable and forted hill, Pompey approaches and sits down beside him. Now he'll consent himself to lose the honour O' the hunted gladiator's overthrow, So Pompey wins it not.

Jov.

That may be true,

For Crassus loves not Pompey. But on that What project found you?

SPART.

This: Let him but wink, While I steal darkly to Tarentum, there T' embark my army. 
Jov.

Hah!

SPART.

I'll find a way

To cozen Pompey and pass by Lucullus, Provided he not follow at my heels.

Gage me but this, and he shall have his niece Unransomed back; deny me, and by Pluto, Pompey alone shall gain the laurel.

Jov.

Jove!

This is a mad proposal. Help you fly!

Will you surrender, or be cut to pieces?

SPART.

Bring forth the captives.

(JUliA and FloRUs are brought in.)

Lo, I'll march tonight:

If Crassus follow me, the girl shall die.

Jov.

Art thou a savage?

SPART.

Ay; or if you will,

A beast, whose nature not being fierce, the hunters Have toil'd and goaded into fury. Nature Makes fewer rogues, than misery. But yesterday, I had saved that maiden's blood, at cost of mine; 
Now, with a cool ferocity, I doom her To perish like a thing abhorred, whene'er The prætor bids me.

$$
\begin{aligned}
& \text { JuL. } \\
& \text { Out, alas, alas! }
\end{aligned}
$$

Didst thou not swear thou wouldst not harm my life? Thou didst, unto thy wife.

\section{SPART.}

Well, speak not of it.-

She is surely taken.-Roman, listen to me: South of thy camp there liest a secret path, Where, for a certain reason, I did send A party, to escape the fears of conflict. Have they been captured?

$$
\text { Jov. }
$$

Who were they?

I know not, but think so.

$$
\begin{aligned}
& \text { SPART. } \\
& \text { Well, they are not taken then? }
\end{aligned}
$$

$$
\text { Jov. }
$$

I'll not say that. A double guard was sent, Under your one time master, Lentulus, Last night, to watch that path.

$$
\text { SPART. }
$$

I have some prisoners,

I would exchange for them-Look, all but her.

$$
\text { Jov. }
$$

But who were these? 
SPART.

Some women and children. Yes, Some helpless fools, not fit to look on battle.Not that I care for them; but I'll exchange them.

Jov.

Some women and children?

SPART.

Sirrah, wilt thou have it? Why 'twas my wife then, and my child. If they Be captured, I'll exchange them for my captives. Crassus shall have his niece too. Nay, I'll send her, Without the exchange, provided Crassus swear To give them freedom, and send back to Thrace. Let him swear this: let them to Thrace, I say,Let them be safe, and I can die.-(Alarums.)

ÆNO.

We are attacked!

Look, general!

SPART.

By heavens, a troop of horse

Rushing against our hill! Why these are madmen?Soft you, they chase some mounted fugitive; Nay, he has cleared them-Look, man look! O gods, Do I not know him?-

Jov.

For this proposed exchange-

SPART.

Look, look! 'Tis he! They are lost! 
428 DRAMATIC WORKS OF ROBERT BIRD

ÆNO.

He is bloody too.

His horse has fallen:

\author{
SPART. \\ But where are they? \\ (Enter Phasarius, wounded.)
}

What, brother, brother,

Speak, speak.-Where are they? Ah!

PHAS.

My brother!

SPART.

Speak!

Dost thou not know me? By thy soul, I charge thee, Speak to me; tell me of my love, my boy!

Where hast thou left them?

PHAS.

Strike me to the heart:

I have robbed thee, brother, of much more than life; And all the blood these gaping wounds have left, Will not repay thee.

SPART.

Art thou mad?

I ask thee of my wife, my boy, my loves!

And thou dost prate to me of wounds and blood!Speak!

\title{
PHAS.
}

I can better speak than thou canst hear.Why madest thou me their escort? Why, $\mathrm{O}$ fool! 
Thou should'st have known that I would quickly lead them

Through the first perils that invited me;

And where a Roman throat was to be cut, Would drag them to the hideous spectacle.

SPART.

But thou did'st bear them off! Come, say it, brother; Thou wert imprudent, but still kind and true.

I'll not be angry-come, I know thou wert worsted, Thy troops cut off-but thou hast saved them, brother!

PHAS.

I would have done it, let my wounds speak for me.

SPART.

They are captives then? O traitor!-my poor wife, And my blithe boy!

The boy-

PHAS.

The troops were cut to pieces;

A Roman soldier-

Cried for mercy to

SPART.

Who spared him!

PHAS.

Struck him to the earth. 
430 DRAMATIC WORKS OF ROBERT BIRD

\author{
SPART.
}

God!-And his mother?

\title{
PHAS.
}

She sprang upon the throat of the black monsterAsk me no more-I faint.

SPART.

My wife! my wife!

Let furies lash thee into consciousness.

My wife, I say! She sprang upon his throat;

What then?

PHAS.

He slew her-but I clove him to the nave.

I could not save, but with my best avenged.

\section{(Falls.)}

\section{SPART.}

There are no gods in heaven;

Pity has fled, and human rage reigns there.Wretch, doth the earth still hold thee? Murderer, Most traitorous, foul, unnatural murderer, If the warm blood of thy thrice-martyred victims Reach not thy soul, and strike it dead within thee, My sword shall sacrifice thee to their fury.-

ÆNO.

Hold, hold! Thou wilt not strike him? Look, he dies! 
SPART.

What, is he dead? All dead? and I alone

Upon the flinty earth? No wife, no child,

[No brother] All slain by Romans? Yes, by Romans.

-Look,

I will have vengeance, fierce and bloody vengeance,

Upon the prætor's blood, upon the prætor's.-

Thou grey and hoary wretch,--for being Roman,

A wretch thou art-I'll send back to the prætor

His niece a corse, and thou shalt carry her.-

What ho, my Guards!

(Enter Guards.)

Jov.

Savage fiend, forbear;

Shed not the blood o' the innocent.

SPART.

$<$ Foolish man, $>$

Was not Senona's innocent, and my child's?

Did they e'er harm a Roman?-Blood for blood, And life for life, and vengeance on the prætor!

FLOR.

Unhappy Spartacus, mar not thy glory With this unnatural and unjust deed.

Let my head fall for her's.

\section{SPART.}

Thy head and her's-

$<$ Fools, ye are Romans, and shall die.

Jov.

Forbear-> 
SPART.

Take them away-

$$
\text { JUL. }
$$

Now may the heavens forgive thee.

\section{SPART.}

Off, foolish girl; there is no pity left:

My heart now thirsts for blood, and blood will have.

JUL.

I have your promise-

SPART.

Breath, that I revoke.

JUL.

I have Senona's; pity me for her,

For she did love me; pity for your child,

Whom I have nestled in my arms, till it

Did love me too, and thou, whilst looking on,

Didst swear no harm should ever reach to me.

Yes, for thy babe and wife, thou didst swear this;

And while thou think'st of them, thou canst not kill me.

SPART.

Well, thou art saved.

$$
\text { Jov. }
$$

Wilt thou, unlucky chief, Now claim the prætor's mercy? Let thy people Return to bonds, and have their lives. 
SPART.

These twain

Shall go with you; the rest is for my vengeance. To show thee that the Thracian still defies,Even in his hour of misery and despair,Still cries for vengeance, still derides the mercy Of the accursed Roman, thou shalt see I court his fury.-Hang this Roman cutthroat Upon a cross, and set it where the Romans May see him perish.

(BRACCHIUs is taken out; and the body of PHASARIUs.)

Jov.

This will steel all hearts, And change all pity into murderous hate.

\section{SPART.}

It is for that I hang him to the tree:

There shall no life be spared in fight today.

Look-let the grooms there kill my horse.-'Tis done:

There shall no flight be known; nothing but death.

Begone, centurion and prisoners. Begone or perish.

$<$ FLOR.

I thought thee cruel, but I find thee kind.

Spare that man, and accept the prætor's pardon.

SPART.

Begone, thou foolish boy, while yet thou may'st.

JUL.

Shall I not thank thee, Thracian, for my life? 


\section{DRAMATIC WORKS OF ROBERT BIRD}

\section{SPART.}

Begone, or die,-and all the hearted griefs, That rack more bitterly than death, go with you, And reach your abhorred country: May the gods, Who have seen Rome fill the earth with wo and death, Bring worse than wo and death on Rome; light up The fires of civil war and anarchy, Curse her with kings, imperial torturers; And while these rend her bowels, bring the hosts Of Northern savages, to slay, and feed Upon her festering fatness; till the earth, Shall know, as it has known no land so great, No land so curst as miserable Rome!Begone, or perish.>

\section{(Exeunt Jovius, Julia and Florus.)}

Let the troops array.

And all that would not die upon the cross, Slaying their horses, to the plain descend, And die in battle.

\section{$<$ «NO.}

You will not fight today?

SPART.

This day, this hour, this minute, fight and die. Why should we struggle longer, in this dream Of life, which is a mocking lunacy, With ever sunshine playing far ahead, But thunderbolts about us? Fight I say. There is no Orcus blacker than the hell That life breeds in the heart. $>$ 
ÆNO.

Alas, dear general,

You are not fit for battle.

SPART.

Fit to make

The Roman mothers howl.- Spare not one life; Shed blood, and laugh; and if ye meet a woman Hiding her babe in her scared bosom, slay her, Slay both.-O AEnomaiis, but to think How lone I stand now on this pitiless earth!Had I not parted with them!-O ye heavens, Could ye look on and see the merciless steel Struck at their sinless hearts?

$$
<\text { ÆNO. }
$$

Give not this way to grief.

Alas, alas,

SPART.

I will not, brother;

My grief is blackened into scowling vengeance.>

ÆNO.

Pray you, come to your tent.

SFART.

To tents no more;

I couch no more but on the corse-strown plain,Draw out the troops-I say, upon the ground, Pillow'd on death; thus shall my slumbers be. Come, battle, battle.

(Exeunt.) 
SCENE V. The Camp of Crassus. Enter Crassus, Mummius, Jovius, Lentulus, Florus, etc. Alarums.

\section{CRASS.}

Thus ends rebellious rage in lunacy;

Despair hath set the gladiator mad.

Look, how with wild and impotent wrath, he rushes

Upon our ready spearmen!-Lentulus,

I am sorry thou didst slay his family.

\section{LENT.}

Nay, 'twas not I. Perhaps, $I$ am not sorry; They were my slaves, punish'd as fugitives.

\section{CRASS.}

Detach the third rank and the cavalry,

On all sides to surround them. Take them prisoners: This soldier death befits them not. Ten thousand Greek drachmæ to the man that brings alive The leader Spartacus.

(Exit Lentulus.)

$$
<\text { Jov. }
$$

That ne'er will be.

He slew his horse, and thus rejecting flight, His life devoted to the infernal gods.

\section{CRASS.}

A valiant madman!-Had he held my girlNay, but I should have storm'd his mountain camp. Look, moves not Pompey from the hills? What, friends, Shall we stand staring at this handful foes, Till Pompey comes to help us? To the front, Away, to the front!

(Exeunt.) $>$ 
SCENE VI. Another part of the same. Enter SPARTACUS, ANOMAIIS, and others.

\section{SPART.}

Leave slaying in the ranks, and rush with me Even to the forum and prætorium, To strike the officers.

Are following on our rear!

$<$ ÆNO.

See, the troops of Pompey,

SPART.

What care I for the rear? I see alone The inviting vengeance beck'ning to the front, Where flows the blood that Rome may bitterest mourn.

Let me beside the prætor. Mark, no prisoners; Kill, kill, kill all! There's nothing now but blood Can give me joy. Now can I tell how gore Inspires the thirsty tiger, and gives strength Unto the fainting wolf.-No prisoners!

On to the general!>

(Enter LENTULUs, with others.)

LENT.

Lo, the bloody chief!

Now yield thee, villain.

SPART.

Murder-spotted fiend, Thou led'st the band that slew my wife and boy! Kill, kill, kill all!

(He kills LENTULUS, and exit with the rest fighting.) 
SCENE VII. The pratorium. Enter Crassus, Jovius, Julia, etc.

CRASS.

Get thee away; thou wilt be slain.

JUL.

I fear not:

Let me look on the battle, and perhaps

Return the gift of life to Spartacus.

CRASS.

Pr'ythee, retire. This man has won more honour. Than even the braggart Pompey; for all ages Shall own there needed two united armies To quell him, yea, two Roman armies. What now? Why fliest thou?

\section{(Enter FLORUS.)}

FLOR.

He has broken through

The second rank. Give me more troops, and fresh, To venge my father's death.

CRASS.

Nay, tarry here,

And mark, how like the timbers of a ship, Crushed in the mighty seas, the sundered wrecks Of this rebellion vanish from our eyes.

\section{SPART.}

(Within.) On to the general! 
CRASS.

What is that cry?

This is a victory, but Pompey shares it.-

What rout is this here at our tents? By heaven,

My guards are reeling in confusion!- Lo,

What man is this, unbuckler'd and unhelm'd,

Gored with a thousand deaths, that waves so wildly.

A broken weapon?

(Enter SPARTACUs, wounded, etc.)

SPART.

All is lost; but cry

Victory! On: I'll reach the general.

CRASS.

Smite him! 'tis Spartacus.

(SPARTACUS is wounded by several.)

SPART.

Hah! Victory!

Crassus, thou diest! I know thee very well.-

Romans are straws.-No prisoners.-Naught but blood.

Why should there be night now?-

(He falls.)

JUL.

$\mathrm{O}$ dear uncle, strike not.

Let him be spared.-He gave me life.-Alas,

He dies, he dies! 
440 DRAMATIC WORKS OF ROBERT BIRD

SPART.

Well-never heed the tempest-

There are green valleys in our mountains yet.-

Set forth the sails.-We'll be in Thrace anon.-

\section{(Dies.)}

\section{<CRASS.}

Thy bark is wreck'd, but nobly did she buffet These waves of war, and grandly lies at last, A stranded ruin on this fatal shore.

Let him have burial; not as a base bondman, But as a chief enfranchised and ennobled. If we denied him honour while he lived, Justice shall carve it on his monument. $>$

(Dead March, etc. Curtain.)

THE END. 


\section{ORALLOOSSA}

The following text of Oralloossa is based on a complete autograph manuscript in the Library of the University of Pennsylvania. The Bird papers contain another complete rough draft of the play in the author's hand. The text has also been collated with the "skeleton script" in the Edwin Forrest Home at Holmesburg, Pennsylvania. Additions found in the acting version have been indicated by square brackets; and deletions of word, line, or scene have been marked thus: $<>$

Oralloossa was finished in February, 1832. It was first produced October I0, I832, at the Arch Street Theater, Philadelphia, Edwin Forrest playing the chief part, for whom it was written as Bird's third prize play.

I "Skeleton script" is an actor's term for a manuscript that omits the part of the protagonist. The Holmesburg MS. gives only cues from the speeches of Oralloossa; cuts in that part have accordingly not been indicated. 



\title{
ORALLOOSSA
}

\section{SON OF THE INCAS}

\author{
A Tragedy
}

PHILADELPHIA, FEBRUARY, I 832 


\section{ORALLOOSSA}

\section{Persons Represented}

Francisco Pizarro, Viceroy of Peru.

FRANCISCO <DE > AlCANTA RA, his maternal uncle.

CARvahal, a Chamberlain.

Diego de Almagro, son of Almagro the Conqueror.

Christoval, his Cousin

Sotela

JUAN, and others

Friends of Almagro.

VACA DE CASTRO, a Iudge of the Court of RoyalA udience, afterwards Viceroy.

A Friar, Gentlemen, Soldiers, \&oc.

Manco, Inca of Peru.

Oralloossa, his nephew, son of AtAHUALPA, and rightful Inca.

Peruvian Chiefs and Soldiers.

OoAllie, a Coya, or Daughter of the Incas, sister of Oralloossa.

A Spanish female Attendant, \&'c.

$S C E N E$. Lima, and the neighbouring Country. ${ }^{\mathrm{x}}$

The acting version adds:

Ist Peruvian Chief.

2d Peruvian Chief.

Gonzalo De Cordova, an Almagrist. 


\section{ORALLOOSSA}

\section{ACT I}

SCENE I. A hall in the Viceregal Palace. Enter Alcantara and De Castro.

DE CASTRO.

You tell me strange things. By Saint Anthony, This glorious region, which, when first I left it, $<$ With treasures and despatches for old Spain, > Seemed in mine eyes the proper paradise, Your crazy quarrels have transformed to hell: Your leaders turn'd to enemies-those Conquerors, Whose deeds of fame had set the world agape, Now changed to currish combatants,-Almagro, $<$ For so the winged story flies to Spain, > Dead by Pizarro's hands; his followers Leagued 'gainst Pizarro in hot insurrection; The pagans rising from their servitude, And smiting both-Now, by my loyalty, These things will bring your great ones to disgrace, Those that they bring not to the block.

ALC.

Great sir,

The true are safe. You have not yet been told, What plots, and treasons, and rebellious war 
Against our Viceroy, and, through him, our king, Begot these grievous troubles. How Almagro Turned a malicious traitor, and so won A traitor's death, shall be hereafter rendered In full to you, - if rightly rumour speaks you, And your authority.

DE CAST.

And what says rumour

Of a poor Judge o' th' Audience? <Sir, you stare With an obsequious wonder, that would raise me Into more high and proud authority Than that I bear.>

ALC.

It has been whispered, señor, You bring a patent, that will seat you in The Chair o' the Viceroy.

DE CAST.

Sir, a Judge-appointed

To aid your ruler, not to supersede him; $<$ To judge of present troubles, not to move him By questioning of those already past; $>$ To quell those spirits that aim at hateful rule, Since, gorged with treasure, their ambition points A loftier path than that their avarice trod.

ALC.

These have been quelled, and by the Viceroy's arm. 'Tis true, some spirits of Almagro's faction Still vex us, but not fright, - some desperadoes, That would make head around Almagro's son, But that our eye restrains them. 
DE CAST.

But the Indians,-

Their mountain risings?

ALC.

Sir, a fabrication

Of the Almagrists, (So the Viceroy notes me;)

They'll smart for it-a knavish stratagem, To fright our war worn Governor from the ease Of his rich palace, to the dangerous toil Of mountain marches; where, instead of foes, Headed by their dead master, Oralloossa, He finds our slaves submissive and contented.

\section{DE CAST.}

But wherefore spake they of this Oralloossa, Whose name, methought, made arméd veterans shake, And even their leaders show a face of terror?

\section{ALC.}

Because they knew, the sudden resurrection Of this dead savage would more convulse the land Than spouting volcano; and more quickly lead Pizarro forth than even the Inca Manco, With all his armies; and thus give them scope For mischief in his absence. For this knave Was son to the hang'd Inca, Atahualpa, And crownéd his successor; and, in a reign Of some few months, when he raised up the signal Of murder and rebellion, proved himself Valiant, and bold, and wise beyond his nation. $<$ Millions of brown barbarians join'd his standard, And fear beset us in our citadels: 
Scarce could our strongest garrisons resist him;> And, with his war-word ringing in our ears, Extermination for the Whites, he rush'd Like a swoll'n torrent, roaring from the hills, Upon our fear-throng'd city. At that moment, When all looked but for death, a mystery Ended his course of marvels; the red meteor Rose, glared and vanish'd-Oralloossa fellNo man knew how; but, it was much suspected, Foully cut off by his ambitious uncle, The present Inca. The danger died with him: Manco had not the affections of his people. Some still are here who speak of Oralloossa, And nod their heads o'er his unfathomed fate, And doubt his death; and on that doubt, Almagro Built up his vain device.

DE CAST.

'Tis a strange story.

ORA LLOOSSA

(Within.) $\mathrm{Ha}$, ha! $\mathrm{O}$ brave! Another moon or two! DE CAST.

What voice is that?

ALC.

'Tis Pedro's, the Peruvian, Pizarro's favourite and most loving slave; <As strange a man as one e'er met withal.> He has grown mad to learn our Spanish arts, Is an excellent and exemplary Christian, And hates his countrymen for their ignorance. 
He has learned to forge out iron into blades, And has a pistol of his workmanship: He writes and reads, curbs in the boldest steed, Tilts like a hero, trains Pizarro's guard; Is a most cunning spy, a snake in craftA treacherous foe, but ever constant friend; And hath a marvellous subtle wit. His cunning Did more than other's bravery, to subdue The hot Almagro.

\section{ORALLOOSSA}

(Within) Brave! Brave!-

How now, Pedro?

ALC.

(Enter ORAlloossa, as PEDRo, with a firelock.) What means this triumph?

\section{ORALL.}

\section{Honourable lord!}

Grant me your gracious pardon: I must laugh! Who would have thought poor Pedro's poorer skill Should venture on the white man's godlike craft, And make that weapon, which makes Spaniards gods!

ALC.

Thank the saints, who have drawn you from the darkness

Of heathen ignorance, to enlighten you; And thank your noble master, who permits you, Against all policy, to be thus instructed. 


\section{ORALL.}

Oh, I do thank him; but his benefits Make dumb my gratitude. I cannot think Of all he has done for me, his humblest slave, But my heart burns to find a recompense.

ALC.

Sir, he speaks true; he is the lovingest knave Was ever mind-enthralled. Some think him crazed In the affection that he bears Pizarro,$<$ He doth so follow him, and, when in presence, So gloats upon him with his keen wild eyes, That his life's privilege seems earned with gazing.>

DE CAST.

A strange unnatural passion in a man, To love the oppressor of his countrymen.What does he now?-

ORALL.

Alas, this altar here-

What is't without the spirit that should inshrine it? This will not harm, this will not slay, while thus, Nor mock the vapour-spirits, when they flash Death through the clouded mountains. This is nothing. Without the greater secret-nay, not more Than is a war-club in a strong man's hands.

ALC.

What seek'st thou, Pedro? 
ORALL.

Ye are Viracochas,

Sons of the gods, and wise! Would I knew this:'Tis not such sand as spreads the blackened beach.-

ALC.

What hast thou in thy palm? What, gunpowder?

ORALL.

Will not your honourable lordship show me, What is the secret of this little grain, That hath a god in its black mass wrapped up, More powerful than the thunder?

ALC.

What, a god?

ORALL.

Perhaps a devil, - a most pernicious devil, Wherewith the cunning may enslave the strong, And the few quell the million. I would know him:

I have worshiped him; he heeds not, till, grown angry,

I cast him in the flames; and then he answers, With a brave noise, and vanishes.

ALC.

Thou art

Half pagan yet. Worship this senseless dust, Which is as gross as thy credulity!-

There's no divinity nor magic here:

Three simple substances, within the reach Of every man, united, form this wonder. 
452 DRAMATIC WORKS OF ROBERT BIRD

ORA LL.

Are they to be found in Peru?

ALC.

Abundantly - upon every mountain-

Eternal sun!

$$
\text { ORALL. }
$$

DE CAST.

$\mathrm{Ha}$ !

ORALL.

Holy saints!-in Peru!

What, on our savage hills? Oh, much I fear, My noble lord now mocks me.

ALC.

The first is charcoal.

Thou shalt hear:

\section{ORALL.}

Charcoal! $\mathrm{Ha}$, ha, ha! Who would have thought it?

Next, sulphur.

ORALL.

Sulphur! $\mathrm{Ha}$, ha! Why that grows on the mountains, in the old craters!

Last, nitre.

ALC, 
ORALL.

Nitre!-O sun!-O holy Maria! Marvellous, wonderful! Ha! ha! I can't help laughing. I know of caverns in the hills, whose floors are white with it. -Nitre-Ha, ha!

ALC.

Nature conjoins these elements together In the hollow chambers of your native mountains; Which, being ignited by the central fires, Produce the eruptive volcano and loud earthquake.

ORALL.

St. Anthony! but I will make some!

ALC.

You may do it easily.

ORALL.

I will make a mountain of it, I will make an earthquake! $\mathrm{Ha}$, ha! the Peruvian shall make a noise, that will cause his noble masters to laughthe hills shall laugh, all Peru shall laugh, and cry aloud on the Peruvian!

ALC.

You must be cautious how you handle it.

ORALL.

Cautious! I will-I will be as cunning as a wild cat, when he creeps through the thicket and circumvents his prey. $\mathrm{Ha}$, ha! Sulphur-nitre-charcoal!- 
(Aside.) O holy sun! I thank thee! Smile upon me A little longer, and thy people yet

Shall live to worship thee! And thou, my father! From thy bright throne of sunshine, look upon me! Vengeance is nigh - thy people shall be free!

DE CAST.

Is the slave mad?

A LC.

It is his natural spirit, That oft bursts out into these rhapsodies, At lighter matters-(Trumpet.) Hark! the Viceroy comes.

DE CAST.

I did not think his grace had been so nigh.

I scarce am fitted for the audience yet.

ALC.

'Twas but the trumpet of the advanced guard: 'Twill be an hour ere yet Pizarro comes.

DE CAST.

Why then farewell. Tomorrow I will pay My duties to his highness.

(Exit.)

ORALL.

By Saint Francis!

Tomorrow! Yea, tomorrow, or the next dayAnd why not now? He will not face my master! Why I distrust him. 


\section{A LC.}

Certain, 'tis most strange

He shuns the present meeting.

\section{ORALL.}

A very treason. Have I eyes? I see't.

Now would I make a weapon of my doubt, And hide it-in his doublet! Holy saints! Nothing but treason! All men now are traitors, Plotting their scurvy malice 'gainst my master. And, noble sir, he is too merciful: He should go seek his enemy in the dark, And then be quick-The dead men are our friends.

ALC.

Thou art too jealous, Pedro.

\section{ORALL.}

Oh, 'tis my love for my great master then. Yet I can see-Have I not cunning eyes? Believe me, sir, I swear, yon young Almagro Is a foul villain, that would sell his soul, To gain his devilish ends upon Pizarro. I see it; I have eyes-I have c'erspied him: He sharps his knife, and, from his window, scowls All day upon the palace.

ALC.

Well, your fear Here jumps with mine; and with the Viceroy's too; Who, in this letter, bids me have him summon'd To meet him at the palace, here, to answer For the feared phantom that he raised. 
ORALL.

A phantom?

Of Oralloossa.

ALC.

ORALL.

Ho! a lying phantom.

What should the Inca do among the hills, When he so soundly sleeps (could one but find him), In a safe couch, hard by the Conqueror?

A LC.

Yes, in his grave! I would that I might see it.

\section{ORALL.}

Thou never wilt; for he himself did swear, No Spanish eye should look upon his tomb; For he would build it in the Conqueror's hall, With the last Spaniard for his pillow!

ALC.

Pedro!

ORALL.

Did he not lie? 'Twas Oralloossa's oath; And what is Oralloossa, when the Spaniard Treads on his bosom? A very mad, strange oath! What, the last Spaniard! A most mad conceit! His grave dug deeply in Pizarro's palace, And the last Spanish corse to be his pillow!

A LC.

A ruffian runagate! But get you gone; Summon Almagro to the palace, here To meet the Viceroy at his earliest audience. 
ORALL.

I am your lordship's slave-A lying oath! A palace monument! and the last Spaniard!

(Exeunt.)

SCENE II. A room in Almagro's house. Enter Sotela and Almagro.

SOT.

$<$ 'S death, I shall burst-Those tattered rascals look As they would sell a traitor for a crust. They are starved, all but the ears.-Lo, ears!> (He locks the door.)

ALM.

How now,

Old soldier? Have you drawn me from the feast, And lock'd the door betwixt me and my guests, To talk to me of riot and excess, And your old grandam's proverbs? Or-perhaps,What do I owe thee? Or rather, what my father? I am governor of Chili, and I'll pay thee.

SOT.

Thou governor! thou boy, that, like a slave, Sit'st down upon thy grievances, without The wit to see them, or the manliness With a brave blow to end them.

ALM.

Grievances!

Am I not lord of Chili, and the heir To all my father's Conquests? Have I not 
My father's friends here sitting at my board, And swearing I'm the next man to Pizzarro? Come, let's return; <I have a stoup of wine, Which, though 'tis sour, is excellent old. Come, come.>

\section{SOT.}

Hark ye, young man: I, who am old and withered, My limbs all stiffen'd, and my blood congeal'd By sixty winters' frosts, now look upon you, Your patient sufferance of indignity, Your base forgetfulness of your father's wrongs, $<$ Ended by his most foul and bloody death, While his red murderer stares you in the face, $>$ As some thing monstrous and incredible! Why $m y$ thin blood doth boil, and my shrunk nerves Find strength and fury, while I look around, And see the assassin of my friend, your father, Perch'd in his seat of honour, and the son Of the great Conqueror crouching at his feet, Smiling and jesting-

ALM.

Tush, you are in a passion,

I crouch not at his feet; or, if I do,

I have an end in 't.

SOT.

And what to-to gain? Perhaps a smile of favour, Followed by a kind order to his slaves, "Give this man gold, but drive him from my doors!"

$$
\text { <ALM. . }
$$

Come, let's to dinner. 
SOT.

Have you appetite?

Now, by Saint Anthony, that meat should choke you, Which came, as a peaceoffering, from Pizarro.>

ALM.

Come, come; our good friends wait us.

sot.

Fy upon them!

A troop of scowling beggars, that will feed Upon the bread of an impoverish'd leader, Yet show no steel to right him.

ALM.

'S life, I tell you,

They are all true men. How should they show their steels,

When they have pawned, or sold 'em? < Or how use them,

After redemption? Upon dogs and cats? >

We want not swords-Pizarro does the killing.

sor.

He kill'd your father!

ALM.

Ay; all flesh is mortal!

sor.

Sirrah, it is thy mother's Indian blood Makes thee so soulless! 
ALM.

My mother was a Coya

$O$ ' the Inca blood; and all the drops she gave me, Have all the fire of their original,

The sun of heaven! Look thou, hotheaded man!

Swear thou art true, and wilt sustain my cause, And hast not come to trap me for Pizarro.

sot.

What dost thou mean?

ALM.

That I am overlooked,

And marked for peril; so that, rashly, I Will take none to my counsels. But forgive me;

I mocked thy love, only to sound its depth.

I have an end, rest you assured of that In all this seeming sufferance.

sOT.

Now by heaven, A true Almagro!-Death to your father's murderer!

ALM.

He stole my heirdom too, I thank him for ' $t$, The regency of Chili and of Cuzco;

$<$ And keeps me here, noosed like a taming tiger To yield him sport, when he may choose to bait me.> Payment I'll have, and vengeance; but the time Is not yet come.

SOT.

Sir, by your leave it is:

Now, while in chase of mountain-hid Peruvians, 
He leaves his city masterless; now, while he An insurrection in the country quells, Himself quell with another.

ALM.

So I meant it,

When (for I'll own it to thee), I myself Begot the rumour of the mad rebellion, And of resuscitated Oralloossa: Vain stratagem, vain hope!

sot.

Why is it vain?

It served you, as you wished, to drive away The governor.

ALM.

Ay; but it left behind

The governor's slave.

SOT.

His slave!

ALM.

Peruvian Pedro;

My evil genius, as he was my father's.

Look you, this kite was once my father's bondman, And by my sire ('tis now perhaps seven months), Given to Pizarro. $O$ the treacherous hound!

Himself did pray it, that, by winding into The secrets of the ruler, he might profit My father, whom he swore he deeply loved. But mark his love! 'Twas he my sire betray'd, 
And gulled him to the block,- - this cunning fiend:

Who, with an Indian's fickleness, soon gave

The love he owed my father, to Pizarro.

This villain is Pizarro's truest friend, And, 'faith, the Viceroy knows it.

soT.

What, a slave?

ALM.

A monster, human, but inexplicable; [Of faith and perfidy, a lamb and tiger]

A man and devil, a perilous enigma;

Who looks upon his master as his god, And all men else his master's enemies.

This rogue was left behind, with cunning eye To pry upon my plans; and pries so sharply, There's naught I do, but he stands by, the witness. While this slave lives, the Viceroy cannot die.

SOT.

Kill him!

ALM.

Ay, do me that; and let Pizarro

Not know me in the act. Catch him asleep! I think his life is charm'd: three times already He hath escaped me.-Hark!

CHRISTOVAL (Within.)

What ho!

My royal kinsman! 
ALM.

My foolish cousin, Christoval.

(He opens the door.)

(Enter Christoval, JuAn, <and other Almagrists.>)

Well, kinsman, what is the matter?

\section{CHRIST.}

Much is the matter. <I have seen the day I would have given a man a cloak, had he but asked it. Look, emperor of Chili, you are appointed umpire in the matter of the cloak. I claim the cloak, and by Saint Dominick, I will have the cloak: but you shall judge.

ALM.

Pr'ythee, cousin, bring not thy foolish disputes before my venerable friend.

\section{CHRIST.}

Foolish! This comes of being an emperor. What may be sport with kings, is a life-and-death affair to commoners: a monarch may laugh at a shoulder of mutton, but a beggar is glad of the bone.

\section{JUAN}

He likens the cloak to a bone, because it is a bone of contention.

CHRIST.

J do no such thing: I liken the cloak to nothing but a cloak. 
ALM.

Pr'ythee, some one tell me what is the matter?

\section{CHRIST.}

Thou art the umpire. Thou knowest, son of mine uncle, we twelve are thy twelve truest friends.

\section{ALM.}

And therefore I thank you heartily.

\section{CHRIST.}

Thou knowest, we twelve are twelve of the poorest varlets in all Peru.

\section{ALM.}

Therein do I sympathize with you. We will be rich enough by and by.

\section{CHRIST.}

Ay, thus have you been singing ever since I placed foot in Peru: And thus said mine uncle Almagro, - "Let my nephew come to Peru, and I will make him a rich man and a prince; and thereby he hinted, he was the same as a king in the land. And here am I, no more in Peru, than in purgatory; and apparelled like a vagabond, as, indeed, are all my friends; and instead of having homage done me as a nobleman, I am jostled out of the way, like anybody's dog: and instead of finding mine uncle a king, I find him not only without a crown, but, holy Mary! without a head; and instead of finding my cousin, his son, the emperor 
of Chili, I find him, next to myself, the poorest man in Peru. I would to Saint Dominick I were in mine own land again!

$$
\text { JUAN }
$$

Ay, marry, or out of the cloak.

\section{CHRIST.}

Ha! I had forgot that. We twelve then, cousin emperor, being, as I said, so detestable poor, and our cloaks being so utterly rusty and tatterdemalion, we found us a conceit for keeping up the array of gentlemen, though our pockets were none of the yellowest.

\section{ALM.}

Well!

\section{CHRIST.}

We had e'en just enough among us to compass one respectable mantle-

\section{ALM.}

Well, well.

\section{CHRIST.}

So we bought one, engaging ourselves to wear it time about, each man his day.

$$
\text { JUAN }
$$

Each man his turn. Nothing about day. 
sot.

To this thing, then, that man reduces them, For being friendly to Almagro! Pho!

Denies them office and employment!-Go to!

You shall take cloaks out of Pizarro's wardrobe.

CHRIST.

Pizarro! Ay, that is another thing I forgot in the controversy. I claps me on the cloak, and saunters about the green fields, not having seen them in sunshine for twelve days; and there I heard a thing may advantage thee to know. $>$ The Viceroy is returning.

ALM.

'S blood, cousin, it cannot be!

\section{CHRIST.}

I say, the Viceroy is returning; <and with the most discreet and disciplined array of cloaks to the back of his knaves, as man never looked upon. $>$ I had it of his advanced guards; some of whom railed at me, for a cursed Almagrist, and bade me beware, lest lying and tricking were followed by whipping.

ALM.

Have we traitors among us?

SOT.

What!

ALM.

How should he trace the stratagem to me? 
SOT.

Nay, there is no certainty he does.

ALM.

That cursed Pedro!

\section{CHRIST.}

I would I were a viceroy! I should have my Coya too.

ALM.

What say'st thou?

\section{CHRIST.}

That I am fitter to love a daughter of the Sun, than gray-bearded Pizarro.

What, what?

\section{ALM.}

CHRIST.

The Viceroy is enamoured of one of thy royal blackeyed cousins, a daughter of the Incas.

ALM.

Hah!

\section{CHRIST.}

This I heard from the rascals, or they slandered their master. He had the princess from Cuzco.

\section{From Cuzco?}

\section{ALM.}

CHRIST.

Ay. 


\section{ALM.}

Her name?

CHRIST.

Baptized Beatrice. The soldiers called her HooHoO-

ALM.

Ooallie!

\section{CHRIST.}

The same; sister of the pestilent dead Inca, Oralloossa.

ALM.

Now is Pizarro bought and sold! Oho!

When age resolves its reverend excellence

Into the boyish vapour of a sigh,

Then may boys shame it with their manliness.

Give me, for him that I would make my fool, An old man doting on a girlish face:

Then shall. I know the measure of his brain, And have his heart of trust, for tickling it. Masters, be merry-the fool'd Viceroy's ours!

\section{CHRIST.}

And whose shall be the princess? Look, I claim her: I have a fancy now to love a princess.

\section{ALM.}

Why you shall have a hundred, if you will. This Ooallie, this Beatrice, I know; And when I dwelt in Cuzco with my father, Built me a loving temple in her heart, That gray Pizarro ne'er can raze away. 
But I'll not tell you further-only this,-

That daughter of the Sun, even by the sun

I swear, shall aid us in our enterprise.-

(Loud knocking.)

What is the matter? < Hark! Look from the window:>

Our friends come not so boldly! - Good my masters, I do assure you this same girl will save us, Spite of Pizarro, or his serpent, Pedro.

(Enter Oralloossa, as Pedro.)

ORALL.

Where be these lurking haters of Pizarro?

ALM.

Villain, why break'st thou so audaciously Into my house?

ORALL.

Ha, ha! It is Pizarro's;

He lends it to thee. By the holy saints, Thou hast no house.

ALM.

Sirrah!

ORALL.

My master loves thee not;

Therefore art thou inheritor of nothing.

Why break I in upon you? By Saint John,

I stood at the threshold, and smelt villainy.

I knew the egg was warming in the nest,

And came to watch the hatching. 


\title{
ALM.
}

Snake-eyed slave, Whom Christian light has only made a Judas,-

\author{
ORALL.
}

Pedro, not Judas!

SOT.

Is this insolent villain

The traitor bondman? Draw your swords, and kill him,

Now, while you have him in your hands.-

ALM.

Hold, hold!

This fury mars us.

ORALL.

What! you draw your swords

On Pedro? On the poor Peruvian,

That great Pizarro smiles on? By the cross,

If you do strike me, I will have your heads.-

I can have 'em any minute for the asking.

\section{CHRIST.}

That's very true.

ALM.

Hark ye, detested slave, Thou hast deserved no mercy at my hands, Who didst make traffic of my father's life,My father that did love thee. 
ORALL.

So he did;

He said so: Yes! he loved me.

ALM.

Wherefore then

Did'st thou betray him?

\section{ORALL.}

Oh, 'tis very plain:

I long'd to see how he, who, on his warhorse, Sworded and mailed, like to a warring god, Among the thousand slayers, laugh'd at death, Would grin upon a scaffold!

\section{ALM.}

Bloody dog!-

ORALL.

I love to see a great man die,- - man That hath a nation murdered or enslaved,Such a great man: 'Tis like the spectacle Of a blood-battened puma, as I have seen, Sprawling beneath a thunder-toppled rock, Strongly convulsed and greatly perishing! I have seen an Inca die-look you, a son Of heaven's resplendent monarch; but 'twas nothing, Till I could hear a Conqueror's last groan! Mark you, a Conqueror's!

ALM.

Thou art a devil!

Why dost thou seek my misery and death? I am not great. 


\section{DRAMATIC WORKS OF ROBERT BIRD}

ORALL.

$O$ holy virgin! thine?

I could love thee; but thou hatest me, I know, And my great master.

ALM.

Him, thou soulless slave,

Who has kill'd a million of thy countrymen, And hanged thy princes!

ORALL.

Well, why should he not?

What were the runagate heathens made for then, But whips, and swords, and gibbets? Know'st thou not,

Heaven was wroth with Indians, and raised up This man to be their scourger?

ALM.

Renegade!

I'll speak with thee no more. Begone.

CHRIST.

Ay, go;

Get out, you cur. Why do you pause?

ORALL.

To do

My master's bidding. Thou, Almagro, art Commanded by the Viceroy to appear, Within the hour that he returns to it, Before him at his palace. This command He makes me by a messenger. Look to it! 
ALM.

What does his highness seek of me?

\section{ORALL.}

To answer

The lying rumour of the insurrection.

You were better drown, than fail.

\section{ALM.}

\section{Insulting upstart!}

I will obey the Viceroy.

\section{CHRIST.}

Hark ye, savage-

\section{ORALL.}

I am a Christian; by Saint Anthony,

A proper Christian!

CHRIST.

Well, a word with you

About the Coyas. I will nothing say That's of yourself, knowing, as I do know, You are a miscreant to the bone. But look you, I am weary of my bachelorship; and therefore Will wive, and, if it like you, with a Coya. Tell me then, savage, for thou art Peruvian, Where shall I find a Coya?

\section{ORALL.}

Under the walls of Cuzco.

In the earth, 
474 DRAMATIC WORKS OF ROBERT BIRD

\section{CHRIST.}

Now thou jestest!

ORALL.

Are not the graves all full? Why where shouldst thou Look for an Inca's child, but in the grave?

\section{ALM.}

Cousin, have done, and let the slave begone.

\section{CHRIST.}

Sirrah, I say thou liest now, since thy master Has brought a live one here from Cuzco.

ORALL.

From Cuzco!

A Coya!-Nay! She was not there!

ALM.

Who was not there?

ORALL.

Ye slander my great master with a lieA daughter of the Sun!-Beware, thou prattler. My master's wrath is swifter than thy tongue, And hotter than thy venom.-An Inca's daughter!See that he smite thee not for this, among Thy other stratagems. When the last trumpets Sound his return, be sure thou seek the palace, And make him satisfaction; or thou art Even ripe for hanging.

ALM.

Villain, get thee gone! 


\section{ORALL.}

I say, come to the palace.-What, a Coya?

Let the graves rot with Coyas, so they spare No wretch to be a Spaniard's paramour!

(Exeunt.)

END OF ACT I. 


\section{ACT II}

SCENE I. A hall in the Palace <with open corridors and prospect.> Enter AlCANTAR: and CARVAHAL.

\section{ALCANTARA}

Even at the gates?-Where bides this dreamer, Pedro? No guards about the palace, to receive him!

\section{CARV.}

All's fix'd and fair; the guards are at the door, The idle citizens in the street; all ready To hail the hero, who has quell'd an army Of shadows, and made conquest of a woman.

\section{ALC.}

Is it then true?

\section{CARV.}

Exceeding true. The Viceroy, With his old armour rattling on his back, Astride his arrogant charger,-and an army That might another royalty subdue,Into the city, with majestic pomp, Conducts the spoils of this campaign; and thatAnd that spoil is-a woman. 
ALC.

Pr'ythee, no jests.

CARV.

Be thou my confessor:

Should not gray hairs bring wisdom and cool blood? Is this a time to toy with amorous girls, When treason scowls among malicious men? Here now, the Viceroy, who should keep one eye Upon the dark Almagro, sets them both Upon a foolish Coya; and next will come, When she has stuffed his ears with lies and love, The thunder of rebellion.

ALC.

Pr'ythee, cease.-

Such words would anger him.-Observe! 'tis Pedro, And with a countenance disturbed.

\section{(Enter ORalloossa.)}

ORALL. (Aside.)

Is there no degradation but must light Upon the blood of Incas? And from Cuzco?

Now does this smite me with much shame and fear.

ALC.

What, sirrah, art thou rapt?

ORALL.

My gracious lord!

Pardon my thoughts, that they were with Almagro. 


\section{ALC.}

What of Almagro?

ORALL.

I do think, sir, treason.

Shall I go to the gates, to meet my lord?

\section{ALC.}

Await him in the palace.

\section{ORALL.}

They did speak,

These vile Almagrists, slanders of my master.

$$
\text { ALC. }
$$

Why let them rail.-

ORALL.

And to my face, did call him

The Inca's murderer!

CARV.

Pho, was that all?

ORALL.

Was't not enough, to call him murderer? His highness murderer? Why men should call A caitiff murderer! And then they added Foul jests about a poor Peruvian girl-

ALC.

Where learn'd they that, the varlets, of the Coya? 


\section{ORALL.}

A Coya, didst thou say? An Inca's daughter?

Now, by my heart, they lie!

CARV.

What, sirrah? Lie!

ORALL.

Did I say that? Lie! Spaniards cannot lie.

But think, my lord,-an Inca's daughter! No, no, They do not lie; and yet, methinks, 'tis false.

An Inca's daughter, and his paramour!

ALC.

And why not, knave?

ORALL.

O yes, why not, my lord?

Is aught too high or noble for Pizarro?

Why not, why not? It doth but honour them, Though the best buds of Peru's royalty,

It doth but honour them, to be uplifted

Into the bosom of the Conqueror!

ALC.

What, thou art moved?

ORALL.

By saints and angels, no!

It is great honour! And yet Peruvians look'd Upon their Coyas as heaven's daughters; yea, Save the holy Incas, none durst touch the robe That veil'd their sacred bodies; and they died, When they but looked upon a man-yes, died; To love, was death! 
ALC.

These were your pagan laws.

ORALL.

A Coya, what, a Coya? I do believe,

It is not true!

ALC.

Why should it not be true?

This passion would make many think thee still, At soul, Peruvian.

ORALL.

By the mass, a Christian!

ALC.

Why should it not be true?

\section{ORALL.}

Where should he find

A Coya? They are vanished from the land:

Is not the palace of their fathers empty?

And the green valleys, where, of yore, they roamed Among the violets, void and desolate?

The children of the Incas have departed:

They were the prizes of the Conquerors.

Yet I remember me that one did dwell Among the hills of Cuzco.

ALC.

This may be she.

Why then, sirrah, 
ORALL.

This? Holy heavens! that princess was Of a most rare, and pure, and delicate spirit, Sweet as a midnight rainbow on the hills, A trembling flower, that would have withered in The atmosphere of shame; and oh, so proud And queenlike in her gentleness, that she Had frown'd shame dead, though by a monarch offered.

ALC.

And yet, thou fool, Pizarro hath a Coya, A Christian Coya; and from Cuzco too.

ORALL.

A Christian!

ALC.

Ay; art thou not glad of this?

ORALL.

An Inca's child a Christian? Oh, rejoiced!

What were the Incas but idolaters,

Foul infidels, and cubs of Antichrist;

That perish'd in their darkness? But, at last,

Come light and honour, faith and dignity;

And a poor pagan girl may reach that grace, To be beloved by angels and Pizarro!

CARV.

I think the knave speaks sarcasm now! A rogue, With a fresh Christian wit.-

(Trumpets.) 
ORALL.

Room for the Viceroy!

(Enter PizarRo, attended [and Gonzalo D'Cordova with his bodyguard]).

Hail to the Conqueror! The Christian's shield, The heathen's scourge, the master of a world!

PIZ.

Our faithful Pedro!-Cousin Alcantara, Are you yet weary of the regency?

We will release ye.-What, our Chamberlain?

See ye have maidens here, with love and honour, To give attendance on the Coya; service Render ye her, the child of royal Incas, As to a monarch's daughter.

ORALL.

Shall not I

Become her slave, that am her countryman, And best will know her pleasures?

PIZ.

Our true Pedro!

Thou shalt be near her, ever, as thou lovest Thy friend and master, with all zeal to serve her. But stay-I'll speak with thee, and there despatch thee.

Gentlemen all, give me your leave, I pray you, Until the hour of audience.-Cousin, a word.

(Exeunt all but Piz., Orall. and Alc.)

What man is this, of whom you sent advice, And of his mystic errand? 
ALC.

The judge De Castro.

Dear my lord,

PIZ.

Let him be the judge.

Yet ran an evil whisper through the troops,

$\mathrm{He}$ bore a nobler title. If it be,

The imperial fool men call Pizarro's master,

Forget Pizarro's services, Pizarro

Is mindful of their merits; and will not

Their fair rewards yield up to favourites.

He conquered not a world, for kings to lavish

On kingly minions; nor a field of empire

Sowed with his blood, for such to reap the harvest.

$<$ Let him look close; his fifths of Peru's gold His frown will dwindle to a tithe, his anger

To nothing; and ingratitude will rob him

Of his Pizarro and Peru together.>

What was this man?

ALC.

A judge, he did assure me:

And yet, with sudden haste, he left the palace, At your first trump, and with such countenance, As makes me fear.

PIZ.

What says my Pedro?

ORALL.

A traitor!

Can I not see? Take thou my head, or his. I can see men's hearts peeping from their eyes; 
And his is mischievous. If he do see

The sunrise, he will plot a crime for night.

PIZ.

Let him be looked to: pray you, seek him out, Ere he have speech with any here in Lima:

I do desire him at the palace quickly.

If I do find him leagued in aught against me,

'Twere better he had laid his bones to rot

Under the unknown sea.-Let him be found.

(Exit Alcantara.)

ORALL.

Shall I now seek the princess?

PIZ.

Tarry yet.-

I love thee well, and think thou art my friend.

ORALL.

Thy slave and footstool.

PIZ.

I have tried thee long,

And find thee truer than the best. All men, From fear or jealousy, have turn'd my foes;

I trust not one: Nay, even my kinsman there,Methinks sometimes that he could play me false. But thou art open to me as the day; Thy heart is bare, and naught I read in it, Save love and honesty.

Pedro is true.

ORALL.

Yes, I am true; 
PIZ.

I find thee my best friend,

Now when forsook of all that love me truest;

My brother Ferdinand by a king ungrateful

Thrust in a Spanish prison; my Gonzalo

Trooping, with my best veterans, at the springs

$\mathrm{O}$ ' th' mighty Maranon; and, saddest yet,

Loved Juan mouldering in his grave at Cuzco.

\section{ORALL.}

Ay: 'twas Almagro helped him there.

PIZ.

Not so:

'Twas Oralloossa's fierce and bloody hand That slew the boy-my curse rest on his soul!

\section{ORALL.}

Yes, curses on his soul!

PIZ.

Thou art my friend.Under thy charge I left my fiercest foes, Almagro and his eleemosynary crew.

ORALL.

Foul traitors all! I am barbarian, Else should I know what keeps them breathing yet, When they were safer in the earth.

$<$ PIZ.

I doubt me, They were not proper watches for my pillow? > 
ORALL.

Let them beside ye, when ye sleep! I watch'd them, And know the knaveries that they meditate.

Nay, they did draw their angry swords on me, When I did catch them plotting.-Wilt thou hear me? Why do they live?

\section{PIZ.}

Not that I love them, but because I fear

Their death might harm me more than can their lives. Men then would call me tyrant and destroyer;

$<$ For men will talk.

ORALL.

Yes, certain, men will talk.>

PIZ.

We must be wise. Thou knowest that men, in secret, Still ponder sourly o'er the Inca's death.

ORALL.

Sourly!

PIZ.

And call it a most fearful deed, Perfidious, dark and bloody.

ORALL.

Dark and bloody-

Many such words; but some have blacker thoughts.

I heard a man, who, in a sort of dream,

Walking alone, did talk unto himself, And give such thoughts unto the babbling air, As made me tremble. Of the Inca 'twas, 
And of his doom, which, he did say, out mocked The best of devils; for hell, quoth he, could plot No deeper horror to affright mankind, Nor send a fiend more dreadful than that man, That schemed out this: For, for myself, said he, That did but look upon't, and gave no help, It haunts my memory with a racking dread, Chills me by day, and, in my dreams, appals With hideous images that will not die, But glare out still, to mad me: Then for him, (For thus he added, in his moody fear,) For him that wrought this horror, it has sealed him Unto perdition; scorpions yet shall sting him With endless anguish; worms shall gnaw his heart, Fires scar his brain, and slow corrupting terror Wither his body, till the hour is come:

Then blood for blood! and pang for pang! and death Horrid as was the Inca's, for his murderer!

PIZ.

Slave!-

ORALL.

But I smote him!

PIZ.

Do such babblers live?

ORALL.

Do not the Almagrists, and a thousand such?

PIZ.

Death to them all! 
ORALL.

\section{$\mathrm{Ha}$, ha! I say, die all!}

Throats to be cut! There is a joy in blood, More than in wine; and when it wells and bubbles Out of mine enemy's heart, it makes me drunk With a fierce rapture!-Shall they die tonight? Give but the word; thy guards are devils all, And will not flinch nor fright.

PIZ.

Nay, hurry not:

Let them not openly die, as by my hand.

Find out some dark device, for thou art cunning, Will turn man's eyes from me. How shall they die? Think too, they have the wit of desperate men, And must be ta'en by craft. How shall they die?

\section{ORALL. •}

Shall I not tell thee? Look, I am not wise:

How should the poor Peruvian be wise?

The savage cradled on the gorgy hills, Nursed, like a bear's cub, in the howling woods, With none to teach him; save his wants and perils? I am not wise; but I have deeper cunning:

The serpents taught me that, for I have watch'd them, When, through the tangled twigs and leaves, they crept Upon the drowsy hare, and, ere he started,

Wreathed the linked folds around his neck, and crushed him!

I have seen the cougar too, where, from the boughs, He leaped upon the browsing llama's back, And, ere he knew his fear, had dug his heart out!Is it enough? 
PIZ.

Use thy best craft in this, And trust my gratitude.

\section{ORALL.}

Give me men to aid,

PIZ.

My body guard-

\section{ORALL.}

Enough. Ha, ha! tomorrow There shall be sights for Lima! Rare, brave sights!Shall I now to the Coya?

PIZ.

Holy saints!

Such thoughts of blood suit ill with her fair image.

Carry me these fair jewels to her beauty;

And, for thou knowest her country's customs well,

Plead for me for her love.

ORALL.

What, for her love!

Is she not then your slave?

PIZ.

Let her not think so.

ORALL.

Why should the miserable savage stand In great Pizarro's likeness? 
490 DRAMATIC WORKS OF ROBERT BIRD

PIZ.

For Pizarro

Knows little how to woo, and less to woo

Peruvian princesses. I swear, this Coya

Gives me but tears, and terror, and rude coldness.

ORALL.

Coldness? Ha, ha! and tears and terror! Saints, But this is rare! A Coya cannot love!

The child of Incas cannot smile on man!

Nay, I will woo her with such cunning words,

Songs of old time, and tender yarabis

As needs must win her to your arms.

PIZ.

Do this,

And-But I'll speak not of the good I mean thee.

\section{ORALL.}

These jewels to her beauty-Costly magic!

Dazzle the eyes of modesty with splendour, And that it watches o'er,-weak virtue,--steal From the unvigiled guardian.-Ye shall have her; My office and these pander gems assure it:

The Inca's daughter is your slave.

PIZ.

Away-

[Her women are comanded to obey thee. Hence] Unto the Coya!

ORALL.

The daughter of the Incas!-

(Exit Pizarpo.) 
The Spaniard's wanton-the daughter of the Incas!-

(Enter a female Attendant.)

Fetch me the Coya.-Why dost thou stand agape?

Fetch me the daughter of the Sun. O thou

Convenient creature, that watchest at the door

To keep out honesty, and let lechery in,

Behold authority-this jeweled chain,

Sent by Pizarro!-Bring the Coya forth, And then begone.

(Exit Attendant.)

O Sun, my father! bitter was thy wrath, When for Peru, most favored of thy climes, Thou didst allot so base a destiny!

Caitiffs and knaves, the refuse progeny Of vilest nations, lord it o'er thy people;

A swineherd governs where the Incas reigned, And the mere ruffian, who would crouch before

A passing grandee in his native land, Treads, in Peru, upon the necks of princes! Shall this thing be, and I, that am the monarch, Still play the bondman to the Conqueror? The lover, to the Inca's murderer? The pander to the Coya's ravisher? Still make my vengeance wait my people's weal, And find but knowledge, where I seek for blood? A moon or two-a week-perchance a day, And Peru looks from out her kingly hills, With her reanimate millions, and beholds The Inca risen, the Conqueror on the Earth, And Oralloossa treading on his neck, I' the ruddy pomp of vengeance!-But I rave(Re-enter Attendant, with Ooallie.) She comes-the Inca's daughter!-Get thee away. (Exit Attendant.) 
Eternal Sun, that look'st upon my shame,

Couldst thou not blast her?-But a look-'Tis she!An offering from Pizarro-Holy princess!

Unveil thy countenance, and look upon me, Thy countryman.

OOAL.

Alas, alas, what art thou?

Thy voice is like a memory on mine ear.-

ORALL.

Thy veil, I say! (He tears it off.) Child of the murdered Inca,

Shame of the living! wanton! Ooallie!

OOAL.

Ah ha!-my brother! Oralloossa!-

ORALL.

(She kneels.)

Inca!-

If but a word thou speak'st, thou diest.-Thou wretch, Thou Christian's wretch!

OOAL.

My brother, and my king!

ORALL.

Ay, on the earth! there kneel, and crouch, and grovel! How comest thou hither, and in the murderer's train. His slave, his creature, his meek paramour?

\section{OOAL.}

$O$ brother, brother, speak not thus to me;

I am not that poor wretch thou callest me,- 
But, though a poor and weak unhappy girl, The Inca's child, and Oralloossa's sister! $<$ Brother, forgive me; take me to thine arms, And let me weep upon thy neck-I have A friend and brother!>

ORALL.

Why comest thou with the Spaniard?

\section{OOAL.}

Why dost thou chide me, brother? Was not I Left lone and helpless, feeble, without friends? Thou know'st my father slumbers in the groundWhere was my guardian then? Thou didst forsake me: Brother, didst thou not leave me, yet leave not Thy spirit's greatness to uphold my weakness? Thou left'st me naught but tears and orphanage.

ORALL.

Thou art my sister! my poor Ooallie!

But thou hast come to see a deed of blood.'Tis well thou hadst but terror for Pizarro; Else had I doomed thee to the living grave: Now thou shalt share my vengeance.

\section{OOAL.}

What dost thou meditate?

$$
<0 \text { my brother, }>
$$

\section{ORALL.}

Art thou fit to hear?

Thou art a Christian! Say, art thou apostate? Dost thou, that hast thy spirit from a god,A beamy essence of the deity,- 
Bend to men's idols, - to the gods of devils? Speak, art thou Christian?

OOAL.

A Peruvian!-

Child of the Sphere! although the cowled priest, Dashing the sacred water on my brow, Strove, with those drops, to wash the beam away. [She rushes into his arms.]

ORALL.

Nay then I know thee for my sister yet,And thou shalt smile.

OOAL.

They said, that thou wert dead.

ORALL.

To all but thee and Manco; but tonight The Inca rises.

OOAL.

O my brother!

ORALL.

Peace;

I am the bondman, Pedro-he that bears

Love-offerings from Pizarro-Tread upon them!

Thus shall his neck be trampled-Hark! Away!The Viceroy!

(Exit Ooallie.)

(Re-enter Pizarro.)

Does my master doubt his slave?

Yet shall the Coya smile. 
PIZ.

What said the princess?

Most excellent Pedro,

ORALL.

Many bitter words;

But by the sun, and by the saints, shall smile.

PIZ.

What! Bitter words?

ORALL.

Hark how the heathen railed I

What beast art thou, she cried, what wretched slave, That speak'st of shame to ears of Inca race!

That art the intercessor of a Spaniard?

What! what!

PIZ.

ORALL.

That hast an arm unmanacled, . And strik'st not at thy master!

\section{PIZ.}

This is a shrewish spirit!

$$
\text { By Saint Peter, }
$$

ORALL.

A doltish slave,

That live'st to see thy country spoiled; thy people Trod in the bloody press of tyranny:

Thy monarchs gibbeted; thy daughters shamed; That look'st on naught but misery, havoc, ruin; That nothing hear'st but groans and clank of chains; Smell'st but corruption; tast'st but gall and dust; And hast no hand for vengeance! 
PIZ.

Now, by heaven,

Thou speak'st me false. A maid so meek and fearful, Could not be turn'd to such a fury. Speak! What said she of the diamonds?

ORALL.

Crushed them, as adders!

Look; her foot

PIZ.

To cast this sudden demon.

I will find a way

ORALL.

Art thou moved?

This fume shall end, this transport rave away. Thou sent'st her diamonds: Wilt thou win her love, Send her such gems as best should please an Inca.

Name them.-

PIZ.

ORALL.

Send her a thousand Spanish heads!

PIZ.

Thou ravest! I have observed, within this hour, Strange passions in thee, fitful, fierce and wild. What is the matter?

\section{ORALL.}

Is it here, or here?

My speech is clear-is not my heart with thee? Thou canst not think what rapture Spanish blood Gives to an Inca! 
PIZ.

Nay, I know't.

ORALL.

Look forth

Upon the golden hills: Now all of them, Those topless and magnificent old mountains, With all their metals, would an Inca give, To see all Spaniards carcassed at their base!

PIZ.

A savage malice! But I think, you jest;

Else should the Coya see the Almagrists' heads.

\section{ORALL.}

Let it be tried.

PIZ.

Thou shalt have full commission.

Win me the Coya to more gentleness.

Meanwhile I must give audience to Almagro;

And after that determine of his doom.

Soothe thou the princess.

\section{ORALL.}

She shall be my lord's, When o'er this waspish terror. But a moment, And Christian thoughts assure her.

(Exit Pizarro.)

Go thy ways:

The kite is over thee, that snuffs thy blood, Slayer of Incas! and the morrow sun, That, at his rise, shall altar on thy body! 
498 DRAMATIC WORKS OF ROBERT BIRD

Sire of my sires! Peruvian deity!

Sink smiling in thy deep tonight, tomorrow

To beam no more upon the Conqueror!

(Exit.)

END OF ACT II. 


\section{ACT III}

$<S C E N E I . A$ room in the palace. Enter CARVAHAL and AlCantara

CARVAHAL

Here's mischief brewing. I would not have my name Almagro, for its credit.

ALC.

Faith, Pizarro

Is greatly vexed with him.

CARV.

Vexed! Sir, I thought He would have bid us cut his throat i' th' presence, And then to put such foul contempts upon him! Such slights and sarcasms as had stirred a dog To snarls and fangs.

ALC.

De Castro, too, has failed

The audience; and this moves him.

CARV.

And the favorite,

Peruvian Pedro,- - what hath set him in This scowling ferment? 'Slife, he roams the palace, Like a chained wolf. 
ALC.

Pizarro hath denied him

A boon, the first he e'er denied to Pedro:

And, being so slight a one, it shows the stronger What anger moves the Viceroy.

\section{CARV.}

What boon was't?

ALC.

He did but ask (and why he asked, is strange, Since he has liberty of all his humours), To ride, upon some whim, out to the fields; Which being refused, his eager spirit frets him Into impatience and great discontent. But let us to the presence, to observe The issue of this fury.

$($ Exeunt. $)>$

SCENE II. A hall in the same. Enter Oralloossa.

ORALL.

No horse, no messenger-And I an Inca.

Without one slave to serve me in my need?

And I an Inca, still to wait the nod

$O$ ' the white-cheeked slayer?-What there!

(Enter Ooallie.)

What, Ooallie!

OOAL.

Oh brother, is it thou?

ORALL.

Who else but I?

Didst thou look for another? 
OOAL.

Another!

ORALL.

Ay ;

Whom shouldst thou look for here but Oralloossa?

Hast thou made friends among the Spaniards? Spurn them!

OOAL.

When through the city's swarming streets they brought me,

A miserable captive in their hands, One face there was among the stranger crowd, Wherein, methought, I saw a friend.

ORALL.

A Spaniard?

OOAL.

Nay, of Peruvian blood.

ORALL.

Then, holy Sun!

Let him but look on me, and do my will, And a chief's province shall be his for guerdon. What, a Peruvian?

OOAL.

And of thine own blood;

Thy kinsman, young Almagro-

ORALL.

Death upon him!

Cub of a harlot, and the Inca's shame.

Death on the mongrel! 


\author{
OOAL. \\ O my brother!
}

ORALL.

Weak fool!

Is not the slave a Conqueror's son; and therefore Thy foullest foe? As fell the blood-stained sire Under my foot, so shall the mongrel son.

\author{
OOAL. \\ Alas!-

\section{ORALL.} \\ A step!-Away. \\ OOAL. \\ Unhappy I, \\ If Oralloossa hate him thus-My cousin! \\ (Enter Almagro.)
}

(Exit.)

ALM.

Ooallie!-Hist! -I give my life to see thee.

OOAL.

I knew that thou wouldst come; thy looks assured me.

ALM.

And, as in old days, in far Cuzco, still

Creeping through perils: For know, thy love has brought me

Under the roof of him who seeks my life, And, did he see me thus with thee, would take it. 
OOAL.

Woe's me, thou art much perilled!

ALM.

Think not of it.

Pizarro woos thee, but thou lovest not him, Till the dove courts the vulture. Shallow tyrant! Thou wouldst not think how vile a thing he makes me-

Calls me to presence, to behold his ruffians Heap scorns upon me, and most biting slights; Then sends me, as to mark with deeper insult, Untended to the doors,-I thank him for't,To steal about his halls, and find out thee!

OOAL.

Alas, thou wilt be slain!

ALM.

But not by him.

I have a sword will all these wrongs requite, And a strong hand shall make his soul account For every tear he draws from thee.-Assure me, Thou art no willing captive!

OOAL.

Shall I need?

Wilt thou not go back to thy father's land?

What! Ooallie?

ALM.

OOAL.

If thou stay'st here, thou diest:

There's not an hour thou dwell'st in Peru now, 
But is forereckoned to thee: tonight, tomorrow, (And oh, perhaps, thou ne'er shalt see the morrow), An enemy's dagger hangs above thy life.

Fly to the sea, and farthest from Peru; Fly now, fly quickly; and thou may'st be saved!

ALM.

Now, by thine eyes, thou fright'st thyself for naught. Pizarro cannot kill me.

OOAL.

No, not Pizarro:

There's one that eyes thee with a deeper hate, And more unsparing fury.

ALM.

If thou lovest me,

Give me that villain's name.

OOAL.

Oh no, no villain!

His name will fright thee: and but now he said, Thou shouldst most surely die.

ALM.

Why thou poor sparrow,

Dost thou not rave? I have no such enemy.

OOAL.

The Inca hates thee.

ALM.

Weak Manco!- 
OOAL.

\section{Oralloossa!-}

ALM.

Heaven bless thy wits-The dead?

OOAL.

Not dead!

ALM.

What, girl!

Wilt thou play on me with those idle mocks?

OOAL.

I do not mock; the Inca is not dead:

But now I saw him, and did speak with him.

\section{ALM.}

Oralloossa?

OOAL.

And, in the dreadful doom he darkly ponders,

Thou, with the rest, wilt perish.-

ALM.

Where?

Spoke with him!

OOAL.

Here.

ALM.

Here! 
OOAL.

In the palace; his holy frame

Hid in a bondman's garb.

ALM.

By heaven, 'tis Pedro!

Dolt that I am! mole-blind!-What does he here?

OOAL.

Oh me, I know not, save to hasten forth $\mathrm{His}$ horrible vengeance.

ALM.

Ay! O noble Spirit!

This makes my daring tame; and yet shapes out An easier pathway to the pinnacle.I am his blood.

OOAL.

He will not think of that.

I have betrayed him, but to save thy life. Wilt thou not fly, and leave him to his deeds?

ALM.

No, by the rood, but aid him for his love; And I have that will win it. Fear not thou: Fate made us kinsmen, and will have us friends. Hark! is't not he, along the corridor stealing?I pr'ythee, leave me now to speak with him: And when again thou look'st, thou'lt see how far I rest me in his love. If still thou fear'st, Look on us from some nook but be not seen.-1. Away, dear Ooallie.-

(She retires.) 
'Tis marvellous!

The very madness of his savage nature!

$<$ And yet most well. - >

$$
\begin{aligned}
& \text { (Re-enter Oralloossa.) } \\
& \text { And now I am amazed, }
\end{aligned}
$$

That, through this shadowy garb, my sottish eyes

Saw not the glimmering glories of the Inca.-

Heaven save the excellent Pedro!

ORALL.

Hah! A traitor!

And skulking through the palace!

\section{ALM.}

Ay, a traitor;

$<$ But not to thee $>$ a traitor to thy foe, But unto thee a friend.

\section{ORALL.}

Art thou grown mad,

That thou shouldst steal thus through Pizarro's halls And rave to me so wildly?

\section{ALM.}

Hark, Peruvian;

Thou walk'st in clouds, but still mine eye perceives thee;

Thou art not what thou seem'st, and yet art more;

I know thee!

ORALL.

Know me? 


\section{ALM.}

And conjure thee look

No longer on me as thine enemy,

But as thy friend and servant.

\section{ORALL.}

Friend and servant

Is this the venting of thy silly spleen, Or babbling of true frenzy?

ALM.

Put me not off.

I know thee, and can serve thee; for the thing tho hatest,

Him will I slay; the vengeance that thou seekest, That will I compass.

\section{ORALL.}

If thou beest my friend,

Thou seest the cross I worship!

\section{(Draws a dagger.)}

ALM.

'Tis the best.

ORALL.

If thou dost know me, tell me in whose side It next shall rankle?

ALM.

In Pizarro's. 
ORALL.

\section{Speak!}

What hand is his that grasps it?

ALM.

Would not his name

From their foundations toss these frighted walls, As though an earthquake shook them? Let me know thee,

Not call thee what I know thee-Oralloossa!

\section{ORALL.}

Thou buy'st thy fatal knowledge with thy lifeDie with thy secret!-

(He offers to slay him: OoALliE rushes in, and arrests him.)

OOAL.

$\mathrm{O}$ my brother, strike not!

ORALL.

Away, thou faithless fool! His lips have uttered The doom that seals them.

\section{OOAL.}

Spare him, brother, spare him! If thou must slay, slay me, that did betray thee, Not him that's faithful.

\section{ORALL.}

That is my hate?

Why should I spare the life, 
510 DRAMATIC WORKS OF ROBERT BIRD

OOAL.

For that it is my love;

For that thou slay'st the one that was my brother, When thou wert not; that was my loyal friend, When all men else, and thou with them, had fled me; And for the knife thou plungest in his breast, Sinks deeper into mine.

ORALL.

Well, get thee gone,

And let me speak with him. The thing thou lovest, Should be of truth.-Son of the Spaniard, speak: Lovest thou the Coya?

\section{ALM.}

Ay; and for her love,

Forget my father and my countrymen, And seal me solely thine.

\section{ORALL.}

Then know, her life Gages thy truth.-Away! Thy love has saved, And thy life answers. Get thee hence: He lives, And is my friend!

(Exit Ooallie.)

ALM.

Cousin and Inca, know me

Thy truest vasșal.

\section{ORALL.}

Not that thou hast the blood Of Incas, spare I thine; but that their daughter Has bought thee with her tears: and for her love, 
I spare and love thee; and for her sake, take thee The partner of my counsels.

ALM.

But why put'st thou

Thy greatness to this jeopardy?

ORALL.

To make

My people free and great! To win them knowledge, Am I the bondman of my foe. But thou Hast science of all Christian arts, and shalt Instruct my people: yea, for this I'll love thee: Thou makest me sooner free for my revenge!

\section{ALM.}

Thou hast, each hour, under thine arméd hand Thy father's murderer.

\section{ORALL.}

$\mathrm{Ha}$, ha! to think of that!

The murderer of the Inca, and my father! The Inca's hangman! Ho! and I did stand Upon the hilltop when they doomed and slew him, And looked down on the deed,-I, I-even I! And saw their felon fingers clench'd upon His sacred body, the immortal image Torn from his brow and trampled on, and he, The Inca, like a base beast, gibbeted! Gibbeted, gibbeted!

\section{ALM.}

Pizarro's life

Can ne'er atone that deed. 


\section{I2 DRAMATIC WORKS OF ROBERT BIRD}

ORALL.

The lives of all,

Though not atone, yet shall they answer,-all!

All Spanish lives, or ere the morrow's sun

Sinks in the sea: so shall the Spaniards die:

Look, all-they shall all die!

ALM.

What, all?

ORALL.

All, all!

If thou hast kinsmen, look to give them up:

There is not one of all these Spanish fiends

Shall see the evening of that day, not one!

When thou seest reptiles rattling at thy feet,

What doest thou? Answer that.-Thou crushest them

The engendering mother and her hissing brood;

Thou sparest not one-There's ne'er a wretch of these But is an obscene serpent in mine eyes.

Full of all venom!

ALM.

Well, I am Peruvian:

The Spanish blood I have, I give to thee.

ORALL.

Thou shalt be chief of Quito! Hark to me:

Tonight (and 'twas tonight thou shouldst have died, Pizarro ordering), Pizarro dies.

This (Displaying a golden sun.) wakes me up my slumbering countrymen, 
And brings me Manco, with his hidden armies, $T$ ' invest the city. Take thy horse and fly, (For on thy speed an empire hangs its fate.) Fly to the hills, thy path on Rimac's brink; And whatsoe'er Peruvian thou seest, Among those wilds, to him this sun display, And bid him guide thee unto Manco: him By this-more powerful than the Christian's crown,Command with midnight armies to the city, To him that wears it. Thou shalt be obey'd.

ALM.

And thou, the Inca!

ORALL.

For thyself, Pizarro

Shall bid thee to a banquet. See thou come, With arms about thee.-Thou shalt see him die!Tomorrow, when the storm of death is o'er, Shalt teach mine ignorant people how to hurl This city of the Conquerors to the earth.

ALM.

Destroy the city!

ORALL.

Ay, the brood and lair:

Bury them in their gorgeous halls, and leave The mouldering ruins for their monument.

Naught shall be spared of Spaniards, save their arts, Their arts and memory detestable.

Away to Manco. Let him march forthwith; The Inca calls him, and the hour is come!

(Exeunt.) 
SCENE III. Another room in the house. Enter Pizarro and Alcantara.

PIZ.

Concealed, thou say'st? De Castro is a villain; Perhaps leagued with the greater one, Almagro.Cousin, these men must die.

\section{ALC.}

Pedro assures me that.

It is most safe:

PIZ.

An excellent villain!

But for his crafty watchfulness, I think, The assassins' knives had reached us. (Enter ORalloossa.)

ORALL.

Let me speak with thee.

Good my master,

PIZ.

Speak; fear not my kinsman.

ORALL.

The Almagrists!-

PIZ.

Those men shall die.

Ay, speak on: He counsels with me.

Tonight?

ORALL.

Then is my master wise.- 
PIZ.

Tonight!

ORALL.

Thou had'st me find a way. How they might fall, and no man look to thee. .

PIZ.

'Tis very needful.

ORALL.

There is but one way.-

Let them sup with thee-

PIZ.

$\mathrm{Ha}$ !

ORALL.

Relent, as though

Thou took'st them to thy favor: thus invite them, And let this banquet be their last.

PIZ.

Thou art mad!

This is the surest way to deck me ever With blood, as with a scutcheon.

\section{ORALL.}

Hear me speak it:

Should they not, when their cups have set them mad, Wax hot and insolent, and assault thy life? Thou kill'st then unmasked murderers! Who shall blame thee? 
Nay, this is wisdom.

PIZ.

ORALL.

Let thy guards drink deep:

And, if thou wilt, why it was they that slew them, I' the drunkard's fury -it was they, not thou;

The servants, not the lord. The very boldness

Of the dark deed, conceals: How wouldst thou dare To slay so openly? Thou art innocent!

PIZ.

My Pedro still! Invite these vipers straight.

Let the guards revel; and all curious eyes

Make fast with drunkenness. Have thy dagger sharp.

Sharp as my hate.

ORALL.

PIZ.

Be wise.

(Exeunt Pizarro and Alcantara.)

ORALL.

Ha, ha! noosed, noosed!

To strike him sleeping, were a worm's revenge;

To gull to grandeur, and then kill, an Inca's!

(Exit.)

SCENE IV. A room in Almagro's house. Enter Christoval, Juan, and other Almagrists.

JUAN

Courage, courage! I tell thee our gallant patron and <that $>$ old < stick of brimstone $>$ Sotela, 
have hatched us a plot, that will give us dinners and cloaks enow; ay, and by the mass, Coyas too, or I am no Christian.

\section{CHRIST.}

$<$ I saw the Coya, weeping in the litter; and, by mine adversity, I longed to knock him on the pate, that had made her so melancholy: for a melancholy woman is nothing of God's making; and he that sets her in tears, is a most discreditable rascal, I assure you. >-But where is my cousin, the Emperor?

\section{JUAN}

Why, thou knowest, he has mounted his horse, and gone into the fields; but after what roguery is not yet manifest.

\section{CHRIST.}

Yea, I remember me < and he had a face as full of meaning as ever my pockets were full of rials in mine own land: but wherefore I know not; only, methought, he looked more mischievous and savage-like than common.> And he said, there should be rare sport tonight, and many kings tomorrow.

\section{JUAN}

Ay; < and bade us, as each man loved him and his own good fortune, to make his house our prison, until he returned, to release us. $>$ Rare sport indeed! Most unconscionable murder-as one may see in Sotela yonder. Look, if the old dragon have not a sword in his hand!

(Enter Sotela.) 
SOT.

What, ye young bloodhounds, stand ye fangless yet, When older nostrils scent the coming hunt?

Get swords, get swords; and see ye have them sharp, $<$ So that the foe, though like a crocodile armed, May find his quiet in one thrust. Get arms.Each man his sword and poniard: $>$ for ye sup Tonight, sirs, with Pizarro.

JUAN

With Pizarro!

CHRIST.

Sup with the Viceroy! <Then, by Jupiter, I have the cloak.>

SOT.

Why thou exceeding goose,

What think'st thou thou art call'd for? To make merry,

In loving wassail? to be drunk? to dance?

To strut and caper with a delicate dame,

$<$ Charm ears, kiss fingers and be fast enamoured?>

CHRIST.

What else? and for what else should he invite me?

SOT.

Not for thy love, but for thy life, assure thee; <To give thee bread, but takes thy bones for it:> To fill thee wine, and rob thee of thy blood. 


\title{
CHRIST.
}

That is, to murder me, a murrain on him! $<$ There's naught but rogues and cutthroats in Peru.> I'll see him hanged, ere I do sup with him.

\section{SOT.}

Nay, but thou must, and with thy sword in hand, If thou canst use 't.

$$
<\text { CHRIST. }
$$

Ne'er let me see mine own land, But I did buy it to kill savages.

\section{SOT.}

Why so thou may'st; but kill me Christians first. $>$

\section{CHRIST.}

Shall we be kings though?

SOT.

Very credible.

\section{CHRIST.}

And marry Coyas?

\author{
SOT. \\ By the hundred.
}

CHRIST.

Ho!

Then I'm resolved. One Christian's life is nothing To bargain for a crown; when Christian monarchs, To keep them kings, ne'er boggle at a million. 
$<$ Hang one's own land-there's no such windfalls there.

We shall be kings all; but I claim to be

King of that land where are the handsomest women. $\rightarrow$

\section{JUAN}

So, by my life, our chief is back again!

$$
\text { soT. }
$$

Then look to see great deeds.-

(Enter Almagro.)

What news, what news?

$<$ Shall the work still go on? What news, what news? $>$

\section{ALM.}

News of the rarest and the best.-Look at me!

<Look I more mighty or magnanimous? >

Have I a sceptre in my hands? a crown

Gilding my brow? my foot upon a throne, Girt by my million vassals?

\section{CHRIST.}

$$
\text { No, by 'r lady: }
$$

You are our poor emperor, governor of Chili.

\section{ALM.}

Faugh! Chili!-a poor wreck of hills and sands, And dwellers as untameable as they.You are my masters,-meditate, decide: What will you have me? governor of Chili, Or king of Quito? 
Determine.-

SOT.

When Pizarro dies,

ALM.

Or perhaps, (but that I'll whisper, Lest greatness stun ye,) Inca of Peru!

SOT.

This is to mock us.

CHRIST.

Inca! nay, he's mad.

Inca indeed! Where is the Inca, Manco?

ALM.

Doing my bidding.-Will ye gape, and stare?

Let the grim condor, on his giant wing,

Flap at the stars; yet shall his flight be lowly

To that my destinies begin tonight!-

I have seen the Inca.

SOT.

Inca! What Inca!

ALM.

Both,-

For there be two in their superb conceits.-

$<$ Heaven save our honesties, what a rogue is man!

As prone to knavery, as a cat to milk;

That swallows vice for daily food, and keeps

That which should be his truer sustenance,

His virtue, for a toothpick! 
sor.

Sir, the two Incas? $>$

But the Incas?

ALM.

First, imperial Manco, That, with his sworded multitudes, lies hid Among the leaves, ready to pounce upon us, When he is bidden by-the other Inca.

sor.

The other Inca!

ALM.

That doth sleep among us;

He that was dead, but rises,-Oralloossa!

SOT.

What, Oralloossa? He that sleeps among us!

ALM.

We have been slumbering on a volcan's brink, The earthquake gathering, but we heard it not; Have seen the Inca, but we knew him not.

We have been fuming o'er our petty vengeance, While the great storm of heavier retribution, $<$ That us was e'en to swallow with our foes >, Was brooding round us.-Oralloossa lives;

And he hath doomed ye. For the hate he bears ye, Read it in Pedro-He is Oralloossa!

$$
\text { SOT. }
$$

That slave, the Inca! 


\section{CHRIST.}

Pedro, Oralloossa?

$<$ Ne'er trust me now, but I did call him cur, And rogue and miscreant! $->$

\section{ALM.}

Be amazed, but dumb.

I am his trusted now; and, at his bidding, Sought out his uncle, Manco, who tonight Circles the city with his hordes; and when The Viceroy perishes, turns his sword against All Spaniards.

\section{CHRIST.}

\section{Here's a wolf!}

\section{ALM.}

I say, fear not.

Thus Oralloossa ordered; but myself More wisely. To their camp the herds shall keep, All save the Inca, and his safest chiefs. I will not trust the knaves too far.-A year Hath Manco played the Inca, and now is So grown enamoured of authority, He will turn rogue to hold it. Let him be Inca, And ye are lords; let Oralloossa reign, And not a man of ye but dies a dog's death.I have saved the city and your lives; and win A Coya, and the sceptre of the sun. $<$ Is't not a most brave fortune? $>$

\section{CHRIST.}

Is't Ooallie? 
ALM.

That name must be forgot,

Or life and greatness.

\section{CHRIST.}

I hope this knavery's honest.

To kill one's foe is naught; but to be traitor

To woman, is to be a dastard traitor.

ALM.

Content you, cousin; you shall know all tomorrow. No harm shall reach her; and the thing that's plotted Shall hurtless end.

\section{CHRIST.}

What is that thing, that's plotted?

ALM.

Nothing-Thou art grown talkative. No more of this.

We have fiercer work afoot.-Are ye all armed?

I'll give ye further hints upon the way.

[The chief of Quito! The fiend that slew my sire

Would buy my vengeance with a petty crown,

But vengeance becks me with a dealer price, Blood and the Sceptre, I will have them both.]

A trump will tell us when the Inca comes.

Keep a firm countenance, and strike no blow,

Till ye the trump do hear, and mark the signal:-

No blow, I say, till I do give the signal. 
SCENE $V$. A Splendid Apartment in the Palace. $A$ banquet set out. Enter Alcantara, Carvahal and other Gentlemen.

CARV.

I care not, I, how many throats be cut:

I hate the Almagrists. But this thing, $t$ ' invite them To share our hospitality, then murder them, Is very knavish politics.

ALC.

Yet 'tis necessary.

CARV.

$<$ Nay, 'tis no matter. I will straight get drunk, And that way end my scruples. $\rightarrow$

ALC.

See, the Viceroy!

(Enter Pizarro, Oralloossa and several Gentlemen.)

PIZ.

Gentlemen all, my friends and confidants, Why for our lives, and for the state's redemption, We stoop to craft and perfidy, I have spoken.

Honesty for the honest, but deceit For the deceiving! Subtlety alone Can guard against itself; and when we strike These evil guests, we but forestall the blow They aim at us.

ORALL.

By all the saints, 'tis true:

They think to murder ye! 
ALC.

And find it needful.

We have thought it o'er,

ORALL.

If ye be not quick,

There's not a man of ye but dies! Ha, ha!

The spirit of blood is rising from his den:

He knows, ye'll feast him! And the raven croaks

Upon the hill; for ye will banquet him!

CARV.

Thou mak'st my blood cold.-

PIZ.

Hark!-No words-The Almagrists!-

Is all prepared?

ORALL.

And shall my master ask?

Had the doomed fiends this deed of midnight schemed, They had not planned it better.-Hark, how hollow Their footsteps sound along the corridor!

For all is lone and silent: Fast and dead

The guardsmen sleep on their drugged cups.-All silent,

Save the few watchers at the door-All silent, All dumb, all blind!-Room for Almagro, room!

(Enter Almagro, Sotela, Christoval, JuAn and the other ALMAGRISTS.)

PIZ.

Hail to our guests! Son of mine ancient friend, Although mine enmity thou didst provoke, 
I put it by, and take thee to my friendship. Let us here quench all burnings of the heart, As scandals to the state, deformities Upon our soldier fame; and have all Spaniards Dwell in forbearance, faith and amity.

What say'st, Almagro? Wilt thou gage thy truth, And sit in friendship at my board?

ALM.

So the saints speed me,

It is my true desire; wherein do join me These friends, whom I beseech your highness know.

PIZ.

They are welcome. To your seats all, gentlemen. At my right hand, Almagro; where thy sire Was wont to sit.

ALM.

Unworthy I, or any,

To hold that seat, wherein my father sat.

PIZ.

A bumper to his memory-Pledge it all. The noblest soldier, had he been but true, E'er smote a heathen.

ALM.

My lord, the noblest soldier, And, by this hand, the truest!

PIZ.

Foolish boy,

Thou anger'st me, to call him true and noble. 
What matchless marvels wrought he with his sword? What people conquered? or what Inca slew?

ORALL.

Hark, hark! What Inca? Was not that great deed Left for Pizarro?

PIZ.

Thou shalt feast thine eyes

Upon the sacred robe and diadem, And say, what hand but mine could pluck them off. What! to my cabinet, for the Inca's spoils; 'Tis fit I show them to this boastful boy.

(Exit Oralloossa.)

Why dost thou fume? Drink to that famous deed, And him that solely wrought it.

ALM.

Very solely.

I thank the saints, my father but looked on, And did not aid thee.

PIZ.

Hah!

ALM.

Shall I be dumb, When thou dost bait me with my father's wrongs And mock'st me with thy sins?

ALC.

What, foul-mouthed, sirrah? 


\section{ALM.}

Why didst thou call me to thy board tonight? To be thy friend, or humble laughing-stock? Strong as thou art, I tell thee, churlish Viceroy, My sire, that on the infamous scaffold fell, Lies nobler in his bloody grave, than thou Upon thy chair of greatness.

\section{CARV.}

Here is treason!

PIZ.

Peace, friends; - I love the spirit of the boy, Though but a mad one.-Shall I make thee friend?

Thou art of turbulent and traitorous blood. I called thee, not to give thee hope to fawn, And prate thy fertile malice into favour; But to make answer, in these midnight halls, For thy long pardoned frenzy.

(A trumpet is heard.)

\section{ALM.}

\section{Look that I}

Answer it not too sharply. Forsworn Viceroy, Thy guile is met, thy treachery forestalled; And that same trump, that speaks thy city lost, Calls forth the swords that slay thee! $-<$ Draw and smite! $>$

Throw wide the doors-

PIZ.

Ho, treason!- 
530 DRAMATIC WORKS OF ROBERT BIRD

ALM.

Draw and smite!

(The Almagrists attack PIzARro and his people.)

PIZ.

Defend me, friend! What ho, my Pedro, help!

(The Pizarrists aredriven out; some Almagrists following.) $<$ What, Pedro, ho! What, help! the assassins strike me!

Ho, Pedro!>

(Re-enter ORALloossa, as Inca; and, at another entrance, Manco and Peruvian Chiefs.)

ORALL.

Who calls on Pedro?-My foot upon thy neck!

Look up! 'tis Oralloossa calls-the Inca!

Slayer of Incas, he, thy slave, the Inca!

Thus for my murdered sire! thus for my people!-

Last of the Conquerors, thy thrall is free!

(He kills Pizarro. They do him homage, in a grand tableau, as the Curtain falls.)

END OF ACT III. 


\section{ACT IV}

SCENE I. A Street in Lima. Alarums. Enter De Castro, Alcantara, Carvahal, and others, [GONZALO].

\section{DE CASTRO}

You see, I have authority to rule;

Pizarro being dead, my charter makes me

His successor. In the king's name obey me.

I have o'erlooked this deed, and ta'en such measures As now preserve you. If ye be true men, Lead on the citizens that I have raised, Against the palace and the murderers:

Thence 'gainst the brown assailants at the walls.

On, for our lives, and for your conquest, on!

(Exeunt.)

SCENE II. At the gates. Alarums. Enter ALMAGRo, Manco, the Almagrists, Peruvian Chiefs, ORALLOOSSA, and OOALLIE, retreating.

\section{ORALL.}

Curst be the treason, that has snatched this prey Out of my grasp. False Manco, thou shalt answer This city's loss. Where are those countless armies, I bade thee bring me? Where those troops, should master

The sworded citizens, whose weak arms expel us? Give me my armies, or I'll have thy head! 


\section{DRAMATIC WORKS OF ROBERT BIRD}

\section{ALM.}

It is too late. Hence to thy safer campThey sally on us!

\section{ORALL.}

Art thou too leagued against me?

Was not this city mine, with all its fiends? And now mine enemy's?

ALM.

It is thine tomorrow.

I weep this city's loss as much as thou.-

$$
\text { ORALL. }
$$

Bring up the troops.

\section{ALM.}

I say, it cannot be.

Hence to the camp, all those that love their lives. Thou wilt not fight thy Spanish foes alone?

ORALL.

Alone, thou knave! What, are these chieftains all? All that mine agent brings? Traitorous Manco, Did I not charge thee, by the Inca's emblem, To bring thine armies to the citadel? And hast thou brought not even to the walls? What, villain uncle!

Thou speak'st to-

MANC.

Stop thy railing tongue: 
ALM.

(A part to Manco.)

Hah-not yet: 'Tis not yet safeThy troops are lodged hard by; and on the instant, When thou hast come to them, thou shalt command them.

ORALL.

My railing tongue? Said Manco that to me? To Oralloossa?

OOAL.

O my royal brother,

Be not moved now; be not now angry with them.

They have mistaken-surely not betrayed.

Leave first this place of peril; then discover

Our uncle innocent. Speak to him, Almagro!

Is he not innocent, even as thyself?

ALM.

Ay, by my troth-as innocent as myself.-

I hoped thou wert with the Spaniards.

OOAL.

Hoped?

ALM.

Nay, thought.

These fierce perturbing tumults make me mad:

I know not what I say-Hark, hark! (Alarums.) Again They sally on us!-Hence to the army.-Come, Cling to mine arm.- 
ORALL.

Come thou with me. This night,

I think all hearts are full of perfidy.

My trust is shaken-But it is no matter:

I'll have them answer quickly at my feet.-

Come thou with me, for thou art very guileless, And he may be a traitor.-Get ye on,

Unto the army; and if it be loyal, All may be answered, remedied, forgotten.

(Exeunt.'Alarums.)

(Enter De Castro, Alcantara, Carvahal, and others of the Viceroy's party.)

DE CAST.

Give arms to all, in the king's name to serve me, His delegated presence; give all arms, That all may follow up this first success Upon the routed murderers.

\section{CARV.}

Noble Viceroy,

Thine energy has saved us from these traitors. Another blow-advance upon the villains, With whom now march the Incas; seize on them, The deified barbarians, and forever Secure against rebellion.

\section{DE CAST.}

Had ye sooner

Of this most treacherous banquet given me word, (As late, in loyal thoughtfulness, ye did,) I had ta'en them in the palace,- -foul Almagro, The hot-brained Incas, and their bloody crew, 
All of them. But let each true Spaniard arm; And, ere the morn, they are our prisoners.

ALC.

$<$ My lord, bethink you now, what grievous terror Besets the citizens. You beheld how bravely They drove the murderers to the gates. Look now! We are deserted. At the gates, they knew They followed Oralloossa! the great dead Living again! the Terrible come back, And slaying in their city! Superstition And terror tie them to their forted walls. They will not follow us against the Inca. $>$

\section{DE CAST.}

Nay, by the rood, they shall, or fall like traitors.

Proclaim it instant as mine ordinance: Honour and guerdon to the willing, shame And axes for the fearful. Quick, delay not, Or the hills shield the murderers from vengeance.

(Exeunt.)

SCENE III. Among the hills, near the Peruvian Camp. Enter Manco and Almagro.

\section{ALM.}

If the gross multitudes see him, thou art lost: They claim their Inca, and he claims thy head.

\section{MANC.}

I fear not that. They have forgotten him, Believe him dead, and long have looked on me As lord and Inca; and my voice proclaims him Lunatic and impostor. All the chiefs Have sworn them mine; and if the people doubt, 
They add their voice to his insanity.

They have denounced him such through all the ranks. He must be silenced, ere we meet the Spaniards.

\section{ALM.}

I'd have it so; or else farewell thy greatness, And that I look for.

MANC.

Hark to me, Almagro,-

The throne I have, thou know'st, it shall be thine, Make it but mine.

ALM.

I understand thee, and remember Whereto I did consent. But now think better. His death secures thee: think no more of her. Her woman's rights are but a feeble reed, Which thou may'st brush aside-Why shouldst thou trample?

MANC.

Is she not daughter of the Incas? Hark; There be a thousand here, that know, and call her, Atahualpa's daughter. She will bid them Behold their Inca in the man we wrong, And they will listen and believe.

ALM.

'Tis true.-

Let her be prisoned somewhere in the hills, Beyond the ear of doubters.

MANC.

I did think thee

Wiser than this. There is no place so safe, 
But the caged witness of a crime may speak, And some one catch the echo-none, but one;<Dost thou not understand?-No place, but one.> They would demand, too, why I dungeoned her:

But when I doom her, as a blot that shames The Inca's purity, 'tis the Inca's law, And rightful justice; and all men are silent.The maid must die,- and see thou art prepared.

(Exit.)

\section{$<$ ALM.}

And why should I not have it as he wills? Why weigh the value of a poor maid's life Against the golden balance of a crown? Ambition startles not at ghastly blood, Nor stumbles, conscience-harrowed, at a corse. And should the aspiring man, that makes his gain Of others' hurts, not hurt himself for gain?

Not, where he stabs another for a purse, Prick his own bosom, for a dearer price, And wound his heart, to laurel-crown his head? Blossoms of nature, ye should never grow In hearts that are ambitious; since the tempter Plucks ye, like weeds, away, till naught takes root, Save the rough tares of sterile selfishness.

Love, pity, friendship, gratitude, away

From such a breast, for ye would make it virtuous; And, virtue, hence, for ye would keep it lowly.But yet she shall not die.-What, Christoval, welcome!>

(Enter Christoval.)

$<$ I did desire you. $>$ 


\section{CHRIST.}

Will you tell me, cousin, Whether or not there's such a thing as honestyI say, sir, honesty-grows in Peru?

Among the fools.

\section{ALM.}

\section{CHRIST.}

Why then, by this right hand, I would that heaven had made me very simple, <And all my friends e'en noddies. Hark ye, cousin;> 'Tis better to be honest and a fool, Than a wise man and villain.

ALM.

Pho-attend me.

I have a thing to say-

< CHRIST.

Never believe me,

But there is villanous talk of treachery

Tow'rds the young Inca, villanous treachery.

\section{ALM.}

Did I not speak to thee of this before? Fy; were thy prattle sure to save his life, His first act would be, to make sure of thine. Give me no more of this, but hearken to me.> Thou askedst once, what mischief 'twas, was schemed Against the Coya.

\section{CHRIST.}

Ay, against the Coya.

Let me hear that, and know what precious rascal Plots malice 'gainst a woman. 


\section{ALM.}

It is her uncle, Manco.

For the plotter,

\section{CHRIST.}

Her uncle, Manco!

A serpent-souled barbarian!

\section{ALM.}

Thou shouldst know,

The Incas held the honour of their daughters,

As Roman chiefs the purity of Vestals, Holy and heavenly; and its loss did visit With the same punishment, a living tomb.A living tomb they dig for Ooallie.

\section{CHRIST.}

What, 'slife! and you permit them? <Cousin Almagro,

If you consent to this, you are a rogue.-

Albeit my cousin, yet a knavish rogue. $>$

\section{ALM.}

Peace, interrupt me not. If I consent, It is to save her from her uncle's hate, Which else will find some deadlier instrument.

$<\mathrm{I}$ had hoped indeed she had lingered with the Spaniards:

Captivity had saved her for a time.-

Whate'er I do, be sure, it is for good,-

To shield my friends, and thwart my enemies. $>$

Therefore, whate'er thou seest to follow now,

Though of a seeming front of villany,

Let not thy honest nature start at it. 
If Manco doom this princess to the grave, Give not thine anger voice; for, after that, If thou hast held thy peace, thine arm shall save her.

\section{CHRIST.}

Nay, if there is no harm, I will be silent.

But all these crooked tricks, I like them not, These dark and shuffling ways to do one good:

I had rather go right forward, and by daylight. $<$ But all's here full of clouds and craftiness.

I would I were in mine own land again:

There's many very honest people there. $>$

\section{ALM.}

I'll take thee to an aged reverend friar, That is my friend; and show thee how, with him To aid and counsel, when the burial's o'er-

\section{CHRIST.}

The burial! What, they will not bury her?

\section{ALM.}

There is a cavern in the hill hard by, Where, though walled up, a man may live for days, And find heaven's sweet and wholesome breath still come,

Through hidden crannies, freshly to his lips.

The solemn doom (a solemn mockery,)

No sooner o'er, and friendly night returned, Ye shall be ready with your picks and spades, To give her life and liberty.-But hark!

Some one approaches.-By and by, I'll show thee More of this matter-Hah!

(Enter OOALliE.) 
$<$ CHRIST.

The Coya!-'Slife,

This plot against her is most damnable.>

OOAL.

Is't thou, Almagro? O, I am very glad,And sorry too-to find thee in this camp.

ALM.

Thou shouldst be hidden from the people's gaze.

OOAL.

Tell me, Almagro, do they frown on thee too?

Dost thou not share his peril?

ALM.

There is no peril.

OOAL.

$\mathrm{Oh}$, but there is, Almagro; hate and treachery

Working against my brother; and, I fear,

My uncle is not true, the chiefs disloyal:

They group together and, with frowning eyes,

Follow his steps; and he is chafed and moody.-

Nay, I did hear them, with seditious whispers,

Call him a crazed impostor. Pray, believe me,

Nor scorn my words, because I am a foolish girl,

Nor think my fearful fancy coins these ills.

$<$ I heard them speak, and use such scowling looks

As honest men ne'er wear. > I saw too, when

My brother would have passed towards the army,

They raised their mutinous spears against his breast,

And said the Inca charged them thus.-The Inca!

My brother is the Inca. 
ALM.

I must hence:

I have a duty which excuses me.

OOAL.

Oh, if thou leav'st me, keep thine eye upon them, Lest, by some treachery, they take thy life.

ALM.

Away-Why dost thou hold me?

(Exit.)

OOAL.

Ah, Almagro!-

Have I not angered him, that he should part So roughly from me?

CHRIST.

Princess, be of good cheer.

If thou suspect him for a knave, ne'er trust me But I am half a doubter in that kind.

But ne'ertheless, keep thou a valiant heart;

For, by mine honesty, thou shalt be saved.

(Exit.)

OOAL.

I shall be saved! Why then I am in peril; And yet Almagro leaves me! Nay, I know, The rest are false, but how can he be so?

ORALL.

(Within.)

Traitors and slaves! I'll have ye torn with dogsWay for the Inca!- 
OOAL.

Out, alas! my brother!

ORALL.

(Within.)

Traitorous chiefs! fling ye your bodies thus Before my path, and are not made my footstools? Way for the Inca!-

(Enter Oralloossa, followed by Peruvian

Chiefs.)

I will have ye thrown

To feed the crocodiles! traitors that ye are, Villains and traitors!

OOAL.

O my brother! Inca!

ORALL.

Ha, ha! thou fool, call'st thou this cozened slave The Inca? Why thou seest, these beggar curs, How they may bait me!

OOAL.

$\mathrm{O}$ dear brother, hear me:

This place is full of treachery; thine uncle-

$$
\text { ORALL. }
$$

My slave!-

OOAL.

Is turned against thee, and the chiefs Basely possest. 


\section{ORALL.}

Dost thou not look to die?

Thou wert the gaze of one's fidelity, And he is false as darkness.

OOAL.

True as day;

Kill me, if he be not. Would I not die, To be thy ransome from this treachery?

Yet is his faith more stable than my life,-

He would not give his honour, even to save thee.

ORALL.

These dogs, thou seest! they raise their spears against me;

They course me on,--like flocking wolves, that follow The wounded llama on his friendless path, So do they course me wheresoe'er I go.

Thou cozening wretch, thou bring'st me to a trap, Betray'st me to my wolfish enemies, And mak'st me mad and pitiful.

OOAL.

$O$ dear brother,

Fly from their rage then, while thou may'st: be safe, Then kill, if I have wronged thee.

ORALL.

Come with me.-

Here, in thine ear-My uncle is a villain;

The chiefs are traitors. Get thee to the camp, And tell my people, how, this hour, foul falsehood Hedges their Inca from them. Do me this, And by my father's clouded face, these rogues 
Shall die like dogs, like dogs!-Vile runagates, Will you permit your Inca seek your Inca, And do obeisance to him? Inca to Inca?

Will you permit him? Follow, curs, and help him To work this regicidal sacrilege.

Follow me, curs-the Inca to the Inca!

(Exeunt Oralloossa and Ooallie, severally, and each followed by Chiefs.)

SCENE IV. Before the Peruvian Camp. Manco throned, and surrounded by the Almagrists and Chiefs. Peruvians covering the hills.

ALM.

Why look ye gloomy, soldiers of Castile, Upon this strange and solemn preparation?

Call it perfidious and dishonourable, Call it impiety and ingratitude; Yet is this deed, as none but this can be, The warrant of your lives, your weal, and fortunes.

ORALL.

(Within.)

Way for the Inca!

MANC.

Stand all fast and ready,

Lest in his fury and his desperation, His arm be fatal.

\section{ALM.}

Fear not thou; he comes

Weaponless to us. 
546 DRAMATIC WORKS OF ROBERT BIRD

ORALL.

(Within.)

Way for the Inca, way!

(Enter Oralloossa, followed by Chiefs, who occupy the entrances.)

Villain and slave, that sit'st upon the throne, Tell me (for these strange sights and stranger deeds, These marvellous, monstrous jugglings of today, Have set me mad). What insane wretch art thou, And these about thee? What am I, that creep, Among Peruvians, hunted and opposed, Frowned on, surrounded, met by clubs and spears, And bade to call thee Inca? What art thou?

MANC.

Manco, the Inca.

ORALL.

Hah! the Inca, Manco?

MANC.

And thou,-

ORALL.

And I?-

MANC.

That most unhappy madman,-

ORALL.

Madman!- 
MANC.

That, in the Viceroy's fall and death,

Didst well deserve our favour and affection;

But by the form which thy distraction takes, (At no less aiming than the name and rule Of perished Oralloossa,) now dost force us To put restraint upon thee.

ORALL.

Perished Oralloossa!

Am I not Oralloossa?

MANC.

Thou, poor maniac!

ORALL.

Look on me, Manco,--brother of my sire,-

I will forgive thee, if thine eyes are dim, Aged and dim-Look on me, knave forsworn! Unnatural uncle! ere I take thy life; Look on my face, and leave thy stolen throne, And sue for pardon, ere I slay thee.

MANC.

Rail on;

Yet art thou safe in thine infirmity.

ORALL.

Speak him, Almagro, if thou art not false; Tell thou mine uncle, 'tis the Inca speaks.

\section{ALM.}

Marry not I. I know thee very well,Pedro the bondman, - my great sire's betrayer; 


\section{DRAMATIC WORKS OF ROBERT BIRD}

For which black deed, the heavens have struck thy brain

With this sore madness.

\section{ORALL.}

Talk'st thou of betraying?

Now can I think that I indeed am mad,

To think thee honest to thy love or me.-

Doth no one know me? None of those, for whom

I sold my heritage? What, not thou? nor thou?

Chiefs that have battled at my side, and struck

For Peru and for Oralloossa? Death!

Ye stony traitors, have ye all forsook me?-

Hark! Ye Peruvians thronging on the hills,

My children and my people! look upon me:

I am your Inca, and will ye forsake me?

For ye, I gave my sceptre to mine uncle;

To win ye wisdom, made myself a slave;

To quell your foes, and make ye free and great,

Wrapped the pure lustre of my dignity

In a foul cloak of treachery and lies,

In servile, base and currish occupation,-

And slew for ye your blood-stained Conquerors.

Speak forth, Peruvians,- - did I do ye this,

And now no more ye know ynur Inca?-Hah!

Are ye all turned to stones? What, not one voice,

To bid me welcome to my throne again?

Nay, then 'tis true; and I or rave or sleep;

And Oralloossa is a dream.-Almagro,

Dost thou remember Ooallie? Bethink thee, And say, thou didst not set them on to this; Say, thou hast no part in this treachery. 


\section{ALM.}

Then should I lie, more deeply than when first I trapped thy soul.-Thou devilish villain! thou, Steeped to the liver in my father's blood,His friend and viper, his trust and his destroyer,Bane of his fortunes, and the tool of mine,Will it not smite thy cozened heart, to know I used thee? I enthralled thee? and did make thee, When thou wert wisest, then the most my fool, When thou wert freest, tnen the most my slave? Thou think'st, 'tis Manco and thy people doom thee: Be this thy comfort-it is I that do it!

ORALL.

The thunder sleeps: else should two hot bolts strike us-

Me for my madness, thee for thy deceit.

I was very honest with thee, and did mean thee

More, for the Coya's sake, than thou didst dream.

But 'tis no matter now: I am not Inca.-

Perhaps ye will kill me-Pray ye, do it quick:

All here is withered, and I should not live:

I only breathe and dream,- - no more.-

OOAL.

(Within.)

Almagro, brother!-

Ho, brother!

ORALL.

Another victim for ye!- 


\section{(Enter Ooallie, pursued. Oralloossa seizes her.)}

Look, thou infernal and pernicious fiend!

This was thy gage, and now shall perish for ye!

(They rush towards him.)

$\mathrm{Ha}$ ! ha! -a knife-blood-blood-

(He falls in a swoon.)

OOAL.

Alas, my brother!

Help, help, Almagro!-Do not tear me from him:

There's none but me to love him.-O Almagro!

Thou shouldst not do this thing.

MANC.

Drag her away.-

OOAL.

Wilt thou (To Alm.) not look upon me?-Pray you, uncle,

Let not my brother die.

(They raise up ORALloossa.)

\section{MANC.}

Thy brother, woman!

Is this the sequel of thy shame? that thou, To be defended in thy wantonness,

Leagu'st with this man, and madly call'st him Inca? Unhappy wretch, mark thou the punishment.

Chiefs and Peruvians, behold the daughter Of Incas, and the Conqueror's paramour! Her doom is spoken by our ancient laws:

A grave for her dishonour. 
OOAL.

$\mathrm{O}$ mine uncle!-

Almagro, speak; am I not innocent?-

God of the sun, thou turn'st away thine eyes!Brother and Inca! hark, they doom my death: Thou art the Inca, and canst save me.

ORALL.

I!

Save thee?-a paramour?-the laws?-a grave?Thou root'st out all my father's drooping stock, Nor leav'st a leaf to wither. Now I know thee! Why should I speak with thee, that art a fiend? I'll turn me to the Spaniards. Hark, Almagro:

Thou hast undone me-I forgive thee that; Cajoled me to the grave-but I forgive thee:

Thou art not yet so base as mine own people:

I say, I pardon thee-But look to her;

It needs not she should die. Art thou still silent?

Thou know'st, thou hell-cat, that, when I had doomed thee,

This young wretch saved; my knife was at thy throat, When she unedged it; I did seek thy heart, And she did shield thee with her bosom.-Look, She is very innocent, very pure and sinless:

Wilt thou not save her? $O$ then madness seize thee, Leper thy brain, and break thy heart by inches!Spaniards, that are my hateful enemies, Can ye look on, and see this maiden murdered? Innocent murdered?

CHRIST.

By our lady, no! 
552 DRAMATIC WORKS OF ROBERT BIRD

\section{AIM.}

Remember!-

Hist! Art thou grown mad?

ORALL.

I did wrong thee.-Speak again:

Thou art his kinsman-Nay, and so am I:

That will not move. But speak again, I pray thee.

Wilt thou be silent, when thy voice can save her?

MANC.

The doom is past-the $\sin$ is manifest.

ORALL.

False churl, thou doom'st her with a lie!-

MANC.

Away!

(They seize upon OoAllie and Oralloossa.)

Away with both. Our laws cannot be broken.

ORALL.

Grant she be doomed then by those laws, base uncle, I am the Inca, and I abrogate them.She shall not die.-

MANC.

Away with both-the madman Unto his cell, the Coya to her grave!

(Oralloossa and OoAllie are forced away at different sides, as the curtain falls.)

END OF ACT IV. 


\section{ACT V}

SCENE I. The Camp of the Peruvians. Enter Almagro, Sotela, Christoval, Juan, and other Almagrists.

\section{ALM.}

Frown not upon me, friends, nor, rashly angered, Thwart the fair fortunes that now smile upon us. The foulest chapter of our fate is done, And all the rest is just and prosperous.

\section{SOT.}

If he, that's chained now in yon crag-built tower, Be Oralloossa, that which follows after, Cannot be just; but 'tis enough, 'tis wise. Doth he still live?

\section{ALM.}

$$
\text { Ay, if his spirit's fire }
$$

Have left it unconsumed. Leave him to Manco. I heard the Inca give to certain chiefs Such hints, as are a sentence.

SOT.

And the Coya?

Shall she still slumber in the dreary cave? 
ALM.

'Tis now the hour the priest should be prepared. What say'st thou, cousin?

\section{CHRIST.}

I wait his reverence.

He hath gone into the dungeon, to prepare The downfaln Inca for his doom: God speed him.

'Tis time the picks were plying; for no man

Can say what horrors, in that secret den, May war with life. - < I would I were home again! - > The Viceroy's army too approaches us:

Who knows, these fooled Peruvians will fight For any chief, but him that's their true master?

ALM.

Fear not for that.-Friends to your posts and charges. $<$ Come thou (To CHRIST.) with me. I must instruct thee yet

What more to counsel for this luckless maid.>

(Exeunt.) $)^{\mathrm{x}}$

I The acting version eliminates Sc. II, but adds at this point the following lines, connecting Sc. I and Sc. III.

['Tis Juan comes-what's this his changed face,

Pale herald of calamity?

Thou has been fellow to a fear.

What hast thou known?

(Enter Juan.)

JUAN

A doom'd one's desperation,

Oralloossa's rage-the Friar's mortal throes.

CHRIST.

The Friar's. 
$<$ SCENE II. A room in an old tower. Oralloossa discovered. Enter the Priest and a Peruvian Chief.

\section{PRIEST}

Is that the prisoner? Miserable wretch!-

Nay, get thee gone; leave me alone with him,

To work upon his spirit as I may.

\section{(Exit Chief.)}

Captive, arise; the fatal hour comes on, When thou must hide thy misery in the grave.Are thy chains heavy, that thou canst not rise?

\section{JUAN}

Cold as the caverned rocks he lies,

The cell unbarred the Inca strangled him;

The arrowy sun shaft flashed athwart the gloom, Its potent ray aroused from seeming death.

The prisoner's mighty form, with fierceness fired.

"My father, lo!" he cried, and madly shook

Aloft his iron bonds-the Friar quailed;

Overcome by terror to the earth he fell,

And on his throat the furious Indian trod.

The aged prelate slain!

ALM.

JUAN

Mine were his dying words-

The prisoner.

ALM.

Aye of him.

JUAN

He fled afar,

Tracking his path with gall.

ALM.

Strike for your lives.] ${ }^{\mathrm{x}}$

Escaped.

${ }^{\prime}$ See Sc. III. 
ORALL.

Chains?-Look-they have rotted.-But there was no need,

When my heart wither'd.-Art thou come to slay me? My breast is open to thee-Strike, and deeply:

'Twere better I were graved.

\section{PRIEST}

Unhappy prince,

My mission is of mercy, not of murder.

\section{ORALL.}

Wilt thou not strike? But that thou know'st, to kill me

Would do me joy, thou wouldst not falter now.

All things oppress; the very chains drop off,

To mock me with the thought of liberty.-

But then the iron still is at my heart.

\section{PRIEST}

Alas, no longer ponder on thy griefs;

But give thy thoughts to death, and that that's after.

Thou wert a Christian once, and shouldst be yet.

ORALL.

I was an Inca once, and should be yet;

That was a dream: I was a man, and should be; But that was madness. Like the fool, that lies On earth and rags, and dreams his soul inhabits The golden-canopied chambers of a palace,So lay I on my bleak and flinty floor, 
And built me gorgeous nothings; wherein I moved Among sweet visages, - but they were fiends. They wreathed a coronet round my brow-'twas fire; And round mine arm the royal mantle-ashes:

Made me a sceptre of a chain-and look!

'Tis broke-my sceptre and my chain: And lo, A delicate angel grew upon mine eyeDust, dust and death!

\section{PRIEST}

No more of this bethink thee;

But of thy holy faith, and of thy sins;

Of death and judgment, for they come upon thee;

Of heaven and hell; of those that watch thy fate, The awaiting angels-

ORALL.

Fiends and demons all!

There was but one that was an angel, and The clod lies on her bosom.-Wilt thou kill me?

Behold, I will not harm thee. If I broke The links that bound me, wherefore should I fly? And whither? I should hunt me but a grave, Silence, and darkness, and forgetfulness.

\section{PRIEST}

Ah me, the grave is nearer than thy wish. The coming Viceroy fills all with affright, And hurries on thy execution.

ORA LL.

I slew the Viceroy!

The Viceroy! 


\section{PRIEST}

Yes, cajoled Pizarro.

Another holds the sceptre, and with armies Hourly increasing, in these hills surrounds us.

With Spaniards?

$$
\text { ORALL. }
$$

\section{PRIEST}

Ay. And had they but a guide, To thread the desert paths unto our camp, We needs must perish.-

\section{ORALL.}

Hah, hah! The sun is up!

The cloud has left his frowning countenance, And I shall set with splendour.-Hearken, man! Ere I do die, the demons that betrayed me, Shall know the avenger! Yea, I will live on, To make requital. For the knaves that marred me, They shall e'en perish; for those things, that were My house, and knew me not,-my forsworn people, That cast me off,-I give them to the enslaver! Fit for naught else-it is their destiny!

\section{PRIEST}

Do me no violence-

ORALL.

To my dungeon door!

To bid my keeper open to thee.-If

Thou stirr'st, or speak'st a word but that I bid thee, I'll hurl thee from the cliff, to feed the condors.Bid him to open wide, and-for my vengeance! 
SCENE III. A part of the Peruvian Camp. Cries and shouts.-Enter Almagro, Sotela, Christoval, and JUAN.

\section{ALM.}

Strike for your lives! A thousand marks of gold To him that stops or slays him.

SOT.

Nay, 'tis fruitless.

Heaven, that was angered at our treachery, Preserves him for our punishment.

ALM.

Behold!

They flag, and follow not! <Oh heaven, with curses Punish this villain priest!

SOT.

And has heaven not?

His mangled corse at the rock's basis lies, The first blood-offering of our destiny. And what shall follow now but woe and ruin?> He will gain from us his Peruvians, And leave us friendless to the Viceroy.

CHRIST.

Yea:

This is't to be dishonest! I did think, There could no good come of such knavish ways.

ALM.

Why dost thou prate thus? All is not yet lost. Interest and fear must keep the Inca ours; And a quick moved assault of all our forces, May lame, or kill, the enemy. 
SOT.

Instant assault.

This is best,-

CH RIST.

Why I will fight with any.

But while we talk of death, must we forget The buried princess?

ALM.

Do what thou wilt, and quickly.

CH RIST.

It is this wrong to her that weighs thee down, And sets the Saints against thee.

ALM.

Save her life.

If that thou canst, and now no more reproach me.

Hence to the cave: and come with me, the rest, To spur the Inca to some stratagem, Some feat, may save us, though the captive fly.

(Exeunt.)

SCENE IV. The Viceregal Camp. Enter DE Castro, Alcantara, and other Spaniards.

\section{DE CAST.}

This is the act of madness,-Oralloossa, The only leader that could general them, Dethroned; and, in his place, the fireless Manco, Or the hot boy, Almagro. It is thus, Heaven, when 'twould punish treachery, doth arm Its rage against itself. It is the scorpion, 


\section{ORALLOOSSA}

Girded by fiery troubles, whose mad fury

Finds all its venom aimed but at itself.

Was it not said, they had resolved his death?

ALC.

Even so, my lord.

\section{DE CAST.}

Their anger aids us well.

That fallen chief, ere this, had struck some blow; But they deliberate.

\section{ALC.}

Were it not safest,

T' entrench here quickly, lest their countless thousands Should e'en surround us?

DE CAST.

Nay, we will march on, And with no fear of this rude multitude.

$<$ The virtue of an army lies not in The stormy members, but in the sole head That guides and governs,-in our day, at least, While men, like ignorant beasts of burthen, only Do well, when well directed: The self same squadrons, With that man, who will conquer all the world, With this, will fly the mere frown of a foe. Perhaps, in future times, when men become, What heaven ordained them, each himself a man, The vigour then of martialness will rest Less with the leader than the led; and armies, Ungeneralled, unadvised, will deeds achieve, That shall fill earth and history with their glory.> 
Find me a guide can lead me through these rocks, And ye shall see these madmen at our feet.What thing is that-what shape of dust and bloodThey bring before me?-Speak, what art thou?

(Enter CaRvahal [CoRdova] leading Oralloossa, wounded.)

ORALL.

Vengeance!

I shall not die, until I have my vengeance.

CARV.

This man, my lord, our advanced posts received. A fugitive from the foe, and hotly followed, And as thou seest, pursued almost to death.

DE CAST.

What art thou, bleeding wretch?

ORALL.

Your slave, the Inca!

DE CAST.

Hah! dost thou say?-

\section{ORALL.}

Your slave, the holy Inca!

King of these hills and herds, your self-sworn slave:

Child of the deity, and yet your slave; That wretch, that slave, the Inca Oralloossa! 
DE CAST.

Most wretched man, art thou at last forsook Of those that spurred thee to thy deeds of blood?

ORALL.

Forsook, cast off, cajoled, betrayed, destroyed! My people gave me to mine enemies. Fettered and mocked me, smote me on the face, And filled my body with these wells of death, And sent me to the Spaniard for revenge!

I am thy slave now; put thy chains upon me, And let me serve thee!-I will teach thee how To creep upon those wolves, that were Peruvians, And smite them with the sword. They gave me up, And I do give them to thee for a prey,To be your footballs and your slaves forever.

DE CAST.

Poor wretch, thou ravest!

ORALL.

Art thou not a man?

And wilt thou not have blood? Chain me, and follow: Thou shalt have Manco for thy knife; Almagro For ropes and flames; my people for your beasts. They would be slaves, and I will have them so. Will you your anger and your vengeance glut? Will you have blood? Almagro's blood? his heart's blood?

Chain me and follow me,-ye shall have all; For your revenge but bears me on to mine. 
<DE CAST.

How shall I trust thee, that hast ever been The foe of Spaniards?

ORALL.

Am not $I$ indeed

Helpless and miserable-wounded now to death? And will ye talk of doubting? Am not I The only one can guide ye through these hills? Put chains upon me, if ye'll have it so; And ready let some stand with spears, to slay me, When I deceive, or when the slaughter's o'er:Let me but live to see't, and live no longer. $>$

DE CAST.

Guide me with faith, and I will set thee yet Upon thy father's throne.

\section{ORALL.}

'Tis fallen forever.

There is no Inca, and no more shall be.

Give me my vengeance, and my father's grave:

It is enough.

\section{DE CAST.}

First let thy wounds be stanched.

\section{ORALL.}

Will ye then palter, till I die? Advance, While I have strength to lead ye. Follow now.Manco! I come-Let me but live to see it! 
SCENE V. Before the Cavern. Enter Christoval, JUAN, and several other Spaniards, with picks and crows.

\section{CHRIST.}

This is the cave.-Hark! dost thou hear no voice? Hist, princess! Ooallie!-Now by this hand, My blood runs chilly.-Should the fright have slain her!

Or some foul reptile, here walled up with her!It was the rankest villany.-Look thou out

(To JUAN, who with one or two others retires). That none approach us.-Would I were home again! Give me a pick.-Toil with your greatest speed, And all in silence, lest fierce Manco hear.

Wrench out these stones: they keep from heaven's fair light

The lovingest wretch that ever man betrayed. ( $A$ shout.)

What is the matter?-

\section{JUAN}

Fly! We are surprised-

ORALL.

(Within.)

Strike them, and give no mercy! Did I not tell ye Ye should destroy them? $\mathrm{Ha}, \mathrm{Ha}$ -

(Enter Oralloossa, De Castro, Alcantara, and others of the Viceroy's party.)

$<$ CHRIST.

Give the alarm! $\longrightarrow$ 
566 DRAMATIC WORKS OF ROBERT BIRD

\section{ORALL.}

A Spaniard! Hah, a murderer!

(He wounds Christoval, who is supported. The others of his party are driven out.)

\section{CHRIST.}

\section{I am slain.-}

Art thou the Inca? Then this blow repays

Much of thy grief; but strikes the innocent.

ORALL.

Nay, now I know thee!-

I am sorry I did strike thee, for thou wert

The only honest villain of them all,-

And the poor fool that spoke for Ooallie!

\section{CHRIST.}

Ay, Ooallie! that is the Coya's name.

The heavens have smote thee with sore madness, Inca: Thou fight'st against thyself; <each thrust is aimed Against thy dearest hopes; each blow falls on

Some one that serves thee.> When thou slew'st the friar,

Thou kill'dst thy sister.

ORALL.

Hah!

CHRIST.

That man was sworn To pluck her from the tomb, <and would have done it, Hadst thou not killed him. 


\section{ORALL.}

\section{Misery! Speak on-}

I slew mine only friend!

\section{CHRIST.}

No, not thine only:

I am the last and only; > me thou killest

For the same office.-Look, this is the cavern, Wherein she lies; and, with these picks, came I, If not too late, to draw her forth.

\section{ORALL.}

Ah!一wretch!

Wretch that I am, I strike at all that love me.

\section{(Christoval is led out.)}

Mad, very mad! the deity has left me.Do ye stand still? Toil for your lives, toil all! Quick, quick, if ye be men-She is not dead! Toil, toil, toil, toil!(He rolls away the stones from the cavern, and others assist him.)

\section{DE CAST.}

This is a sad mishap.

Most wretched prince, thy strength is not for this. Come < thou aside, $>$ and let my people toil.-

ORALL.

There-pause!-put arms to this-Hark, hark, I hear her!

She screams for succour! Stand away-Ha, ha! I hear her!-Ooallie!-

\section{(He enters the cave.)}


DE CAST.

This is the saddest

Of all this war's most sad occurrences.-

Quick! Give him aid-

(Re-enter ORALlOOSSA, from the cave, bearing OOALlIE dead.)

ORALL.

Fresh air! a drop of water!-

Look, if she live! Why princess! sister! wake!Nay; she is very cold.

\author{
DE CAST. \\ Thy care is vain.- \\ ORALL.
}

Save but her life, and I will live your slave, And love ye! O ye have some Christian arts Might make her breathe again! What if she be So still and cold-'tis but a swoon.

DE CAST.

This is no swoon, but death.

Away-

ORALL.

Strikes sorest at the innocent.-Thou seest!

$$
\text { Yea!-Misery }
$$

She was my sister.-Well, take her from my sight.She was the only angel in mine eye-

Mine orphan sister-A soft and loving heart-

A meek and gentle spirit-A very warm soft heartIce, ice!-Take her away-

(She is carried back to the cavern.) 
DE CAST.

Unhappy prince!-

ORALL.

Black, bloody, fiendish-Let the murderers die!Almagro-Manco-Dead-my sister-Blood!-

(He swoons.)

$<$ DE CAST.

What, doth he follow her? Nay, he will revive.Lay him i' the cavern at her side, until

The assault be o'er. And let each heart remember, When armed against th' Almagrists, 'twas Almagro That wrought this frightful and this cruel deed:

Remember this, and as ye strike, revenge!>

(Alarums. The scene closes, as they go out, and as some carry ORALloossa to the cave.)

SCENE VI. In the Peruvian Camp. Enter ALMagro, Sotela, Manco, and several Chiefs. Alarums.

A LM.

Assailed? and now forsaken by the Inca?

sor.

It is the fruit of one unhappy error.

Speak thou with Manco, with what fire thou canst; I 'to the lines, to check the foe awhile.

(Exit.)

ALM.

Why dost thou falter, Inca? Bid thy people Rush on the foe: their numbers will o'erwhelm him. 
MANC.

Thou hast deceived me, Spaniard.

\section{ALM.}

I have made thee

Inca; and, for thy aims, have blurred my name With a foul act: And wilt thou now desert me?

MANC.

My people will not fight: they steal away; The chieftains fly with them, and say, 'twas thou Unchained the captive, who is with the Viceroy.

ALM.

Foul liars all! The Inca with the Viceroy!

MANC.

Was it not he, that slew thy cousin?

\section{ALM.}

My cousin slain?

MA NC.

Even at the cave, where thou Didst plot new treachery-treachery to me; For which I leave thee to thy fate.

\section{A LM.}

$\mathrm{O}$ heavens,

Comes it to this? I pray thee, leave me not: I broke no faith with thee. Or, if thou fliest, Leave me some succour from thy thousands. 
MANC.

Not one.

They do my bidding, when they leave thee,- scattering

Each for his hiding place. They are dispersed.

ALM.

Dispersed! Nay then, false churl, thou hast destroyed me.

And yet, I pray thee, for thy own good weal, (For, without me, thou art no longer monarch,) Leave me not rashly.

MANC.

Ay-farewell: thy destiny

Is dark'ning, and thy planet sinks to night; And all that rest with thee, will perish with thee.

(Exit Manco, with the Chiefs.)

ALM.

Perfidy, perfidy! thy sting is now In mine own bosom.-

(Alarums. . . Enter JUAN.)

What! why fliest thou?

${ }^{\mathrm{I}}<$ Back with me to the front for death or victory! $>$

\section{JUAN}

$<$ For death alone.-Fly, if thou canst, and fleetly. $>$ The lines are forced, the foes are at my back;

Thy friends are slain.-

$\therefore$ The acting version transposes this line to the third speech of Almagro below. "Now is my falsehood," etc. 
572 DRAMATIC WORKS OF ROBERT BIRD

\section{ALM.}

Where is Sotela?

$$
\text { JUAN }
$$

All dead, or captive.-Hark!

\section{ALM.}

Back to our friends!

They call for me!

\section{JUAN}

They are thy foes, that call.

Wilt thou be ta'en, to die upon a block?

\section{ALM.}

Now is my falsehood punished!-Do not leave me. (Exeunt Almagro and Juan.)

(Enter, at the opposite side, De CASTro, Alcantara, and others of the Viceroy's party.)

DE CAST.

It is a victory: But follow on.

Rewards and honour to the man that takes Alive the rebel murderer, Almagro.

(Exeunt.)

SCENE VII. Before the Cavern. Distant shouts. $<$ JUAN

(Within.)

Fly - save thyself $-I$ die $! \longrightarrow$

(Shouts. Enter Almagro.) 
ALM.

What, left alone!

All dead, that followed me! O heaven, I feel The arrow that thou strikest through my soul!

Would I had died in innocence, or ere

I gave me up to comfortless ambition.-

(Shouts.)

They come!-Some nook for present shelter!-Here, This rock's abyss, that yawns like hell before me. Yet courts me on-A rock to cover me!

(He enters the cave.)

SCENE VIII. The interior of the Cavern. The body of OoAllie on a distant shelf. ORALloossa discovered reviving. Distant shouts.

ORALL.

Ah! gloom, black gloom-Among the world of spirits, But solitary.-Yet the curses ring, And the long yells, as on the madding earth; And the pang quivers in my flesh, and darkness Covers my brain, as all were mortal still.Again? again? And where be those that shriek? Ah! but I dreamed her corse was at my side, And her cold cheek upon my breast.-An Inca, Shut in the funeral cave-Again? Approach, If ye be fiends, and look upon a man Worn with more miseries than yourselves!-Oho!

(Enter Almagro. Shouts.)

They come, they come! and this one hath an aspect Of a thrice damned demoniac!- 
574 DRAMATIC WORKS OF ROBERT BIRD

ALM.

Yet am I safe.-

\author{
Ah, they follow!
}

ORALL.

Ha, ha!

ALM.

O saints, a voice,

Howling with laughter, in this pit!-A man!What art thou? Speak!

ORALL.

Ha, ha! The sun, the sun!

He will not have his child go darkling down!

Thou beest Almagro! ho! Almagro!

ALM.

And thou?

Heaven!

ORALL.

The miserable.-Look, thou man, That turn'dst this day to darkness, and, from thrones, Com'st to the den where Ooallie doth lie.-

ALM.

O Christ, her grave, her grave!

\title{
ORALL.
}

Yea, in her grave,

The fiend that filled thee with her blood, hath left thee;

He gives thee to me, gives to Oralloossa!- 
Lo, buried Incas! he that broke your sceptre, Is in my hand! Look up, dead Ooallie,The slayer perishes!

\author{
ALM. \\ $\mathrm{O}$, mine arm is nerveless!
}

(Oralloossa strikes him down.)

ORALL.

My uncle chained me,-it was thou that taught him; My people left me,-it.was thou corrupted; My sister perished; -it was thou that doomed her! The Inca wept-but is I that smite thee!

(He stabs him. Enter DE CASTRO, and the rest.)

DE CAST.

This way he fled-What! tear them asunder!

ORALL.

\title{
(He kills Almagro.)
}

Ho!

Thy blood is mixed with mine.-

DE CAST.

Raise up his head.-

ORALL.

Hard by the victim-Look-it is accomplished. Grind them to dust!-I give them for thy slavesThe maid!-the murderer!-To the grave-The Inca.-

(He dies. Tableau.)

THE END. 



\section{THE BROKER OF BOGOTA}

The following text of The Broker of Bogota is based primarily upon the complete manuscript copy, made by Mrs. Bird, wife of the dramatist, in the collection of Bird papers at the Library of the University of Pennsylvania. In the collection are also two autograph copies of the play, both incomplete. The text has also been collated with the acting version in the Edwin Forrest Home at Holmesburg, Pennsylvania. Additions from this version are indicated by square brackets; omissions of word, line, or scene are enclosed in brackets of this form: $<>$.

The Broker of Bogota was finished in January, 1834, and first produced by Edwin Forrest at the Bowery Theater, New York, on February 12th of the same year. Its success was marked and immediate, the part of Baptista Febro becoming a permanent rôle in Forrest's repertoire. 

THE BROKER OF BOGOTA

A TRAgedy 


\section{CHARACTERS}

Marques de Palmera, Viceroy of New Granada.

Fernando, his son.

BAPTISTA FEBRo, the broker.

RAMON

Francisco $\}$ his sons.

Mendoza, a merchant, father of JuAna.

Antonio de CABARERo, a profigate, friend of RAmon.

PABLO, an inn keeper.

Silvano, servant of Febro.

LEONOR, daughter of FEBRO.

JUANA, daughter of MENDOZA.

Gentlemen of the Court, Citizens, Alguazils.

Scene, Santa Fé de Bogota. 


\section{THE BROKER OF BOGOTA}

\section{ACT I}

SCENE I. The Street near FEBRo's house. (Enter MENDOZA and RAMON.)

\section{MENDOZA.}

You have your answer. Come no more near my house: I'll have no disobedient, disinherited sons there. $<$ Come no more near to me. $>$

\section{RAM.}

Señor Mendoza, you make my unhappiness my crime and condemn me for my misfortune.

\section{MEN.}

Truly, I have so learned to criminate misfortune ever since I found that, when one grief springs from ill fate, twenty come from our own faults. I have never known a young man sink in the world, without finding he had overburdened himself with follies.

\section{RAM.}

If you will listen to me, I will show you how much you wrong me. 
MEN.

Wrong you? I wrong you not: you are your own wronger. < I should be glad to be rid of you.>

RAM.

You treat me with much shame, señor; but, for your daughter's sake, I forgive you.

MEN.

So would I that your father did you for my daughter's sake; for then might I think of you for a son. But now, you must pardon me-Think no more of that.

RAM.

Señor Mendoza, I have your promise to wed Juana.

MEN.

I made that promise when you were your father's heir; and I break it, now that you are your father's outcast. I will have no discarded son for my child's husband, believe that.

RAM.

My father will restore me to his favor.

MEN.

When he does that, I will perhaps take thee to mine,not before. <Fare thee well, señor.>

RAM.

Señor Mendoza, it is said you will marry Juana < to another? 
MEN.

And if I do, señor, who is to gainsay me? >

RAM.

To Marco, the young merchant of Quito?

\section{MEN.}

Content thee, señor Ramon, Marco is neither discarded nor poor, nor ill spoken of; and will be a good husband for a good man's daughter. <Farewell -Come to me no more. $>$

RAM.

By heaven, it shall not be!

MEN.

Oho! it shall not be! You are the King of Castile, señor <Ramon!> You will have fathers marry their children to men of your choosing!

RAM.

Señor, you will break my heart. It is enough to lose my father, my family - all-yet you will rob me of my betrothed wife.

\section{MEN.}

Betrothed to Baptista Febro's heir, not to Ramon the penniless and houseless. <You are scurrilous.> I will talk with you no more. Farewell-and come no more near me: my daughter is not for you.

(Exit.) 


\section{DRAMATIC WORKS OF ROBERT BIRD}

\section{RAM.}

Misery follow thee, thou false old churl, And age's torments! till they rack as sore As the fresh pangs and agonies of youth. Perhaps his daughter is not much averse; Yet many an oath, with many a sigh, of old, Breathed she for truth and loving constancy.

\section{(Enter CABARERO.)}

CAB.

Hola, Ramon! brother Sorrowful! Señor Will-o'-thewisp! are you there? I have been seeking <for > you.

RAM.

I should think then thou hadst some execution upon me; for who else now seek me but my creditors?

CAB.

Why, thy true friends, thy true friends (for am not I a host?), thy true friends, Cabarero. Come now, hast thou been petitioning thy father?

RAM.

I tell thee, I had better ask an alms of the cutthroat on the highway, than of my father.

CAB.

$<$ An alms! $>$ Oh, thou art the smallest-souled pretty fellow in all Granada here. Why dost thou talk of an alms? Art thou not thy father's eldest son? 


\section{RAM.}

Had I been the youngest, I should have been the happier.

\section{CAB.}

Yea, thou shouldst have been a counter of beads, a beggar of blessings, a winner of the elder brother's portion. Pish! thy brother Francisco is a rogue; he has ousted thee from thine inheritance.

RAM.

If any one have done that, thou art the man. I am ruined, Cabarero, and thou art my destroyer.

$$
<\mathrm{CAB} \text {. }
$$

Now, I think thou art repenting of thy sins; but thou goest about it the wrong way.>

\section{RAM.}

Look, Cabarero, there is my father's roof. There is no swallow twittering under its eaves, that has a merrier heart or a gayer song, than were mine once, when I was a boy under it.

\section{CAB.}

Ay, faith, and that wast because thou wert a boy, a silly boy. Now wert thou a man, a discreet and reasonable man, thou wouldst be even as merry as before. <Thou dost not think thou wert born to be always in a grin? $>$ 
RAM.

I was the eye of my mother, the heart of $-<$ my father > ; my sister loved me; my brother - <ay, and my brother >-ay, they all loved me; and there was no one that did not smile on me, from the priest at the confessional to the beggar at the door. By St. James, I had many friends then; and I deserved their favor, for I was of good fame and uncorrupted.

CAB.

I see thou art a man whose head is likely to be as empty as his pockets. 'Slife! uncorrupted? $<$ Thy nose uncorrupted!> Bad luck is the lot of the best.

\section{RAM.}

Antonio, I say, thou hast destroyed me. Until I knew thee, I abhorred shame, and <it is true> my hand was as stainless as an infant's.

\section{CAB.}

It was thy father's scurvy covetousness that put thee on to showing thy spirit.

RAM.

Thou didst delude me. By the heaven which has deserted me, I did not think this hand could rob!

CAB.

Pho, thou art mad! Remember thou art in the street. 
RAM.

That is the word, Antonio.-I robbed him-robbed him like a base thief: and then I became the outcast.

CAB.

And then thou becam'st a fool! Thou didst but take $<$ what was $>$ a part of thine inheritance.

\section{RAM.}

$<$ And $>$ yet he forgave me that!

CAB.

He did not hang thee, for that would have brought shame on his house. [Forgave thee!] He forced thee to be foolish, and then discarded theeturned thee off like a sick servant-abandoned thee.

\section{RAM.}

$<$ I think he should not have done that. Had he forgiven me that!

CAB.

Forgive! Nay, he forgave old Miguel the mule-driver a debt that would have kept thee in bread for a year; and yet it was evident to all that Miguel cheated him. But to forgive his own flesh and blood is another matter.

RAM.

He forgave Miguel because he besought his pardon: I have not yet besought him. Dost thou remember the holy history of the prodigal? $>$ Perhaps if I humble myself to him, he will forgive me. 
CAB.

If thou art of that mind, thou may'st see, $o^{\prime}$ the instant, how he will spurn thee. Look, he is here, with thy sister, and-Pho! thou tremblest!'Tis Mendoza, father of thy fair Juana.

(FEBRo, with LEONOR and MENDOzA, crosses the stage.)

RAM.

$\mathrm{He}$ has discarded me too, and Juana is given to another. How can I entreat him? See, he will not look upon me!

\section{LEON.}

Father, will you not speak? It is my brother Ramon.

FEB.

The carrion vulture with him.-Get thee in.

I would I had no sons-What? in, I say!

(Exit LEONOR into the house.)

Señor Mendoza, what you have said is well:

I must needs own the contract was too rash.-

We are both agreed it shall not bind us more.

I hear young Marco is a worthy man:

Give him your daughter and heaven bless the match. Will you enter, señor?

MEN.

I thank your favor, no.

This thing despatched, I will to other business. Good evening, señor.

FEB.

You will be happy, friendTake no wild hothead boy to be your son: 
Look to his friends: If Marco have but one Loves mirth more than integrity, discard him. These gadflies are our curses-Fare you well. (Exeunt MENDOZA and FEBRO, the latter into the house.)

CAB.

Oh! o' my conscience, a loving father!

RAM.

He gave me no encouragement to speak to him. Had he but looked upon me kindly, that look would have cast me at his feet.

CAB.

What, at his feet? Not if he were twenty times your father. <'Slid, at his feet! Why > he would have spurned thee. Didst thou hear? He has absolved Mendoza from the match,-robbed thee of Juana,-nay, and absolutely counselled the merchant to marry her to your rival. A loving and merciful father! He ruins thee every way. Were he mine own father, I would-

RAM.

What wouldst thou do? Thou wouldst not kill him?

CAB.

By mine honor, no. I hold any bodily harm done to one's parent altogether inexpiable. But I would not forgive him.

RAM.

I will not! 
CAB.

Why, that was said like a man.

RAM.

He forgives not me, he pardons not a folly, and how shall I forgive a cruelty? For a single weakness, he punishes me with all degradation and misery; expels me from his house; looks not on me in the street; leagues with those who wrong me; leaves me penniless and perishing; and even persuades another to break faith with me, and give my betrothed to a stranger: And how shall I forgive him?

CAB.

Why, thou shalt not.

RAM.

I will not. I am even a desperate man; and so I will yield me up to the wrath of desperation. Art thou my true friend?

CAB.

Else may I have no better hope than purgatory.

RAM.

We will kill the merchant of Quito.

CAB.

No, the saints forbid! no murder. He hath not money enough with him.

RAM.

Why, thou dost not think I will slay him for money? 
CAB.

And for what else should you be so bloody-minded? Thou art not mad enough to cut his throat because he loves thy mistress?

\section{RAM.}

Thou knowest, if he live, he will marry her.

CAB.

Oh! she detests him, and loves you.

\section{RAM.}

Yet will she wed none her father mislikes; and her father likes not me.

CAB.

Wherefore? Because you have lost your father's favor? No, because you are called a wild fellow, and hate chapels? No. Because you are no longer the hopeful heir to Baptista Febro, the rich broker? Ay: there lies his disgust, thence comes his indignation. Now were you the veriest rogue in Bogota, he would love you well, so you had but money.

RAM.

Why do you tell me that? I know he is mercenary; nothing will win his heart but money, a curse on it! I would I were rich for Juana's sake; but for myself, I care not for gold-It has been the ruin of me. 
CAB.

Thou speakest like an innocent goose. Money, < sirrah!> 'tis the essence of all comfort and virtue. Thou carest not for gold! Give me gold, and I will show thee the picture of philosophy, the credential of excellence, the cornerstone of greatness. It is wisdom and reputation-the world's religion, mankind's conscience; and what is man without it? Pah! 'Tis as impossible honesty should dwell easily in an empty pocket, as good humor in a hollow stomach, or wit in a full one. Didst thou ever see integrity revered in an old coat, or unworthiness scorned in a new? <Thou carest not for gold!> 'Slife, it made my blood boil to hear you say so.

\section{RAM.}

Well, after all, as money or murder must rid me of my rival, tell me how one can be more easily come at than the other.

CAB.

Why, you rogue, there is our silver mine! We have been hunting it long; we must needs be near the vein.

RAM.

That stratagem is growing stale. I sware but this morning to an old friend, of whom I desired to borrow money that we had discovered the tomb of Bochica the Indian emperor, which was doubtless as full of gold as the Inca's grave in Peru; but the knave laughed at me, <and said if I found no gold in it, I should have plenty brass. $>$ 
CAB.

The rascal! and he lent thee no money?

Not a real.

\author{
RAM.
}

CAB.

There is no gratitude among friends. $<$ Do thy good offices to strangers; and courtesy will teach them the grace of thankfulness. Canst thou cheat nobody?

Cheat, Antonio?

RAM.

CAB.

Pho! be not in a passion. All's honest that fetches money. $>$ We must have gold, or Juana is lost.

RAM.

Ay - Set me to what roguery you will, so it may regain her.

CAB.

The tomb of Bochica, the Indian emperor! I know not by what hallucination it happens, but I never hear thee mention that, without thinking of the vaults of thy father.

$\operatorname{Hah}$ !

RAM.

CAB.

Now, were he not thy father, couldst thou not have the heart to rob him? 
RAM.

Rob him!

CAB.

That is, as long as he oppresses thee so tyrannically. Faith, I would even steal mine own share.

\section{RAM.}

Thou dost not seriously advise me to be such a villain?

CAB.

No, good faith-I? I was jesting. But I will tell thee what thou shalt do. Thou shalt ask him for money.

RAM.

And have him spurn me again?

CAB.

Tell him thou art in danger of a prison.

RAM.

I will go near him no more. No more begging! The prison first.

CAB.

$<$ Why, we must have money. I am sorry to tell thee, some evil rogues have disparaged us among the free gamesters, and they will be free with us no more.> Pablo the innkeeper is wrathful with thee, and says he must have money for thy food and lodging. 
RAM.

The villain! He has had my last dollar.

CAB.

$\mathrm{He}$ is not so merciful as thy father; but he has harboured thee long. Hearken-I will go to thy father.

Thou!

$$
\text { RAM. }
$$

CAB.

And entreat him for thee very piteously.

RAM.

$<$ He will fill thy pockets with curses.

CAB.

Why, then I will cheat him.

RAM.

Cheat him?

CAB.

Oh, thou dost not care?>

RAM.

You may rob him, if you will: I care not.

CAB.

I will cheat him with good security, and will fetch thee the money. < But I must not give thee too much hope: he will think I borrow it for thee, and will 
refuse me. But $>$ do thou in the meanwhile endeavor to speak with Juana. Marco must not have her.

\section{RAM.}

Not if any new dye upon my soul can preserve her. $<$ Do what you will, or can; and if you fail, we will consider another way to amend our fortunes. $>$

CAB.

All the men of Bogota are our enemies-How many of them have money in thy father's hands?

RAM.

Why more than I can tell thee. But what has that to do with their enmity?

CAB.

So much that if one were to break Baptista's vaults, we should have much feeding of grudges.

\section{RAM.}

Say no more of this.

CAB.

Look, here comes thy friend Mendoza again!

RAM.

Where? Nay, thou art mistaken: 'tis another, and a greater than Mendoza, and one not more our friend. Seest thou nothing beyond that muffled cloak? It is the Viceroy. 
CAB.

The Viceroy! I warrant me, he is spying over us. What does he in disguise? and near thy father's house?

RAM.

Perhaps I could tell thee. But let us be gone. He hardens my father against me.-Let him not see us.

(Exeunt.)

SCENE II. A room in FEBRo's house. (Enter FEBRO and LEONOR.)

FEB.

Come hither, Leonora. What, my girl, That stranger youth I bade thee see no more, Dost thou still speak with him?

LEON.

I hope you are not angry.

Alack, dear father,

$<$ FEB.

Is it so?

Comes he still near thee?

LEON.

$\mathrm{Oh}, \mathrm{I}$ am sure indeed,

I never gave him countenance.>

FEB.

Give him such scorn, if still he followed thee,

I charged thee As should have driven him from thee: for, indeed, 
These trashbrained idlers, that do follow thee, Sighing in chapel, staring in the street, And strumming silly lovesongs at thy window, They are but things of naught,--base, lazy rogues, That hunt for rich men's daughters for their prey, And now they haunt thy steps the more, because The broker, weak old Febro, that must die, In natural course of age, ere many years, Hath but two heirs to share his hoards.

\section{LEON.}

Dear father,

Will you not then forgive my brother Ramon?

I know he is very sorry he e'er grieved you;

And on his heart your wrath must needs be heavy.

FEB.

If thou believ'st so, then, in time, beware

It fall not upon thine. <In sooth, I think,

Thou art leagued with him to vex me. $\rightarrow 0$ ye saints!

Punish these villains that seduce men's sons,

Making them villains; and with vengeance follow

The knaves that teach our daughters disobedience.

LEON.

Dear father, none shall teach me that.

FEB.

They shall not,

When thou seest no more rogue Rolandos.

LEON.

Indeed, I think, he is honest.

Father, 
FEB.

$$
\text { Nay, a knave! }
$$

He doth not come to me, but ever shuns me. $\mathrm{He}$ hath no friends; no man in Bogota Hath made acquaintance with him: he flies all Like a scared thief, save only thee alone, $<$ And comes to thee like one, cloaked, almost masked, As when he followed thee from the carnival. Now were my Ramon what in youth he was, He should be thy protector, and soon drive me This wasp away.

\section{LEON.}

If he return again, $>$

I'll bid him come no more;-I will indeed, Till he has talked with you, and satisfied you.

\section{FEB.}

Why there's my girl! Let him but come to me; I'll tell him that I mean thee for another.

\section{LEON.}

Another, father! I do not wish to marry.

FEB.

Thus silly maids will talk! Why, thou poor finch, A gentleman hath asked thee for his wife,Rich, I assure thee, virtuous, honorable, And a hidalgo.

LEON.

And so is Roland, too. 


\section{DRAMATIC WORKS OF ROBERT BIRD}

FEB.

Speak'st thou of Roland? Thou wilt anger me.

He a hidalgo! By my faith, I think,

Some heathenish villain, that with magic arts

Hath wound about thy spirits. He I meant,

Is Baltasar, son of Don Lucas Moron.

Dost thou name him and Roland in a breath?

I' faith, thou stirr'st me,-

(Enter Silvano.)

What would'st thou, Silvano?

SILV.

A customer to your worship.

FEB.

It is a holiday.

I will no business do today.

SILV.

Your favour

Must pardon me. It is his Excellency.

FEB.

His Excellency! oh thou foolish knave.

To leave him waiting!-

(Enter PALmera.)

Please, your noble highness,

Pardon my silly fellow.

PALM.

Good Baptista,

Forget my state, -it is too cumbersome. 
I am even your humble suitor and poor friend.My pretty Leonor! Now, by my life, Which like a desert river, flows away, I would some green and flourishing plant like thee Had rooted by my current: then indeed I should have seen the surges of my age Dash with a sweet contented music on, Nor thought their course was sterile.

FEB.

A silly maid.

Your highness is too good.-Go, Leonora.

(Exeunt LEONORA < and Silvano.>)

$<$ A silly maid! and yet, or I do dream, Loving and true. And yet-But that's no matter.I am at your highness' bidding. >

PALM.

Sit down, Baptista.-

$\mathrm{Oh}$, then, I must be viceroy and command you.-

I have much to say to thee.

FEB.

I am sorry your grace

Did not command me to the palace.

\section{PALM.}

Perhaps I have a reason I could tell you.

No.

Febro, you have my confidence, and know,

What were a wonder unto other men, How one can sit upon a viceroy's chair, Yet heap no wealth about him. 
FEB.

Please your highness,

Your predecessors on Granada's throne,

$\mathrm{Ne}$ 'er found a lack of gain; and, sooth to say,

I do remember when no mine could yield,

Though by a thousand Indians daily wrought,

So rich a revenue as the rod of state

In one man's hands, were but that man the viceroy. .

\section{PALM.}

Such was its wealth, and such may be again, To him with heart to use it. But for myself, I cannot stoop to use those under means, That fill the purse of office; and I would gnaw Sooner my food from off my barren trappings, Than gild them vilely with the fruits of fraud, Sales, bribes, exactions, and monopolies, The rich dishonour of prerogative.

$<$ I will this kingdom leave with no man's curse, And no man's scorn; and to mine own land bear Even the poor burden that I brought with me, An honest pride and pure integrity. 'Tis from this thought that I make use of thee, Out of that lean estate I have, to win Such gain as my necessities require, And such as though my state must keep it secret, I have no shame to grasp at.

FEB.

Would indeed This principle should come with your successor.> 


\section{PALM.}

I have some gold, which I would have you place Even at what profitable trade you can, But not in peril; for indeed it is After some worthless antique lands in Spain, The only portion I can give my son, But now arrived in Bogota.

FEB.

Shall faithfully be served.

\section{Your highness}

\section{PALM.}

I doubt not that.

Soon as you will, some trusty messenger

Send to the court, and he shall bear the gold.

FEB.

My son shall be despatched.

\section{PALM.}

Your son, Baptista!

FEB.

My son Francisco,-I dare assure your highness, A trusty youth, and most unequalled son.

PALM.

In sooth, I thought you meant his elder brother.

FEB.

Francisco, please your grace,-an excellent boy, < Mine only hope and comfort,--a dutiful son.> 
It is a holiday, and the youths have left Their prisoned warehouses, and look for mirth In the gay squares and streets,-all but Francisco. He nooks him at his desk, and still pores o'er The weary mysteries of accounts, as though Wisdom, as well as wealth, were writ among them.

\section{PALM.}

A commendable zeal. But tell me, Febro,This should have been the elder brother's office.

Pardon me, Febro; but beshrew my heart, I speak to thee in friendship, when I meddle In family affairs. You are too harsh: Indeed it is the towntalk, your severity To your discarded son.

FEB.

It is the towntalk! The town will disobedience teach to children, Then censure fathers, who do punish them. This is the course, and justice of the town!

PALM.

But still, men say, the penance you inflict Is all too heavy for his boyish follies.

\section{FEB.}

Follies! No doubt, they told your excellency He idled at his task, sometimes made blunders, Played truant oft, and sometimes laughed at chapelSuch follies!

PALM.

No, I must needs own, for truth, They were of darker color,-running forth 
With youths disorderly and riotous, Unto the tavern and the gaming-house.

FEB.

Riotous friends!

Drinking and gambling! Sir, these are such follies In youth, as fraud and robbery in men; And he who clouds his dawn of life with such Shall have a fouller tempest for its close.

\section{PALM.}

And yet these are such ills as gentleness Might best reprove; and, for those after crimes, Surely your son has not plunged into them?

FEB.

I do not say it! There is no man dare say it.I say, my Ramon is a foolish boy. Your highness cannot say I e'er accused him Of aught but folly.

PALM.

The more unwise your anger, Which may compel him into crime. Baptista, $\mathrm{He}$ is the only one of your three children Whose weakness vexes you.

FEB.

I'll not say that.

PALM.

What, Febro? And the paragon, Francisco?

FEB.

He never gave me pain. 


\section{PALM.}

\section{And Leonor?}

My pretty Leonor?

FEB.

The world's best daughter!

\section{PALM.}

$\mathrm{O}$ foolish man, that art not yet content,

When heaven that crowns thee with two perfect joys, Dashes a little gall upon the third!

$<$ Wilt thou be harsher than all other sires, Because thou art happier? Oh, believe me Febro, There is no father but must much forgive; There is no father but must much lament; > And I, that have but one child to mine age, And him would have an angel in my love, Even see him tainted with the spots of youth, And envy thee that hast such bliss with thine.

FEB.

Sir, I have heard the young Fernando bore him Like a most just and virtuous gentleman.

\section{PALM.}

And yet, though but few days in Bogota, His heart is tangled in a low intrigue, A base amour. But shall I drive him from me? I will not ape thy cruelty, but bid thee Follow mine own mild counsels, which will give thee Thy son again, a loving penitent. 
FEB.

Sir, I would have him feel in sharp extreme The bitter issues of his degradation.

'Tis need he feel them.

\section{PALM.}

They oppress him now:

I saw him sad and moody near thy house, Humbled to earth.

FEB.

Ay! but with Cabarero!

The villain that seduced him into folly, And still cajoles him on. He has his choice,That caitiff, or his father-He has his choice!

\section{PALM.}

Well, well, think better of him. He loves the man, Who seems to be his fast unflinching friend. Think of my counsel.

FEB.

At your highness' feet!

Francisco shall attend you to the palace,What, boy! Francisco!

PALM.

I prythee, keep thy house.

I will not have thee follow to the doors.

FEB.

Your excellency's slave. 
SCENE III. The street at FEBRo's door. (Enter Silvano and Fernando.)

SILV.

I do wonder at your presumption, señor Rolando.

FERN.

And I do wonder at thine honesty. If thou wilt not for money, oh then for love bear my message to the fair Leonor.

SILV.

To peep from the window, and see how prettily thou wilt kiss thy hand to her! Art thou really a hidalgo?

FERN.

I am really a hidalgo, a Spanish hidalgo.

SILV.

And your worship does really love my mistress?

FERN.

My worship does most devoutly adore your divine mistress.

sILV.

And if you gain her good will, you will make her your worship's wife?

FERN.

If I gain her good will, I will fly straightway to the altar; < If not, I will 'e'en betake me to the halter. $>$ 
SILV.

Why, if thou wert an honest gentleman, thou would'st demand her of her father. He would be glad to have a hidalgo for a son.

FERN.

Oh, thou art a silly fellow. I am a poor hidalgo, which is naught to a rich commoner.

SILV.

Señor Rolando, I like thy face indifferent well; but I think thou art some rogue, and no noble.

FERN.

If thou wilt be as loving as I am noble, hear my petition, and beseech my young divinity to look from the window.

SILV.

Who knows? Why, señor Febro is within.

FERN.

How shall he hear the silver voice of his daughter, when his ears are filled with the golden jingle of his coffers?

SILV.

Well, stay a moment till his excellency goes.

FERN.

His excellency! What excellency?

SILV.

Why, his excellency the Viceroy. $<\mathrm{He}$ is a great friend of my master. $>$ 


\section{FERN.}

Oh! fire and furies! the Viceroy! Now, I remember . me, $I$ have to meet a friend in the great square.

\section{SILV.}

Stay, señor Hidalgo, here comes his excellency. Señor, you are a rogue! God be with you! (Exit FerNANDo.) Well, thou art a mysterious, goodfor-nothing, agreeable rascal, I warrant me; and somehow, I begin to love thee. But thou hast a wholesome dread of great men.

(Enter, from house, Palmera, Febro, and Francisco. LEONOR appears at the door.)

\section{FEB.}

Heaven keep your excellence a thousand years!

Thou hast thy charge, Francisco.- - Heaven save your highness!

(Exeunt Palmera and Francisco.)

Silvano, hast thou heard more things of Ramon?

SILV.

Please your worship, I heard he was last night at Mateo's gambling house.

FEB.

The wretched boy!

SILV.

And, please your worship, he hurt one with his dagger for calling him a cheat.

FEB.

A cheat! Would he had never been born! 


\section{SILV.}

But then, it was a slander; or how should he have stabbed a man for telling the truth?

FEB.

Ay, slander, Silvano! He could not cheat.

SILV.

$<$ And the gambler's boy that told me, he is a most notorious liar.

\section{FEB.}

- I cannot but believe it was a lie. $>$

SILV.

And then, if he had cheated, he should have had money; whereas, they say, he is in great poverty; and Pablo the innkeeper threatens to put him in prison.

FEB.

In prison! I have been too harsh.

SILV.

$<$ But that, I think, is only to make your worship pay his debts; for Pablo is reckoned to be a rascal.

FEB.

Will Ramon agree to this roguery?

I will not pay a real.>

SILV.

Please your worship, I have heard no more of his doings. 
FEB.

Well, I did love him well,- -but that's no matter. My Rachel loved him too, as her first born; And, for a boy, he was the lovingest one Mine eyes ere looked upon. < Get in, Leonora. Why wilt thou stand at doors, to be gazed on By these young bawbling wantons of the town? They'll smirk at thee, and wink, and kiss their hands:

I know them very well,- -such gewgaw brains, And hearts of rotton stone, and trash and liesWilt thou not hear me? What? (Exit LEONORA.) By all the saints,

She is the very apple of mine eye.

She does not love this fellow:-the whim of girls, To have well-favored youths a-wooing them.- $>$

I know that rogue-is it not Cabarero?

$\mathrm{Oh}$, the base villain! had he been but hanged

Six years agone, or ere he looked upon

My foolish boy!-Well, will he speak with me?

\section{(Enter CABARERo.)}

Come, let us in.

CAB.

Hola, you money-vender!

You reverend old blood-grater of the poor!

Tarry, I'll speak with you.

FEB.

Give me a little patience.

Now all the saints 
CAB.

Come, how stand

Your vaults and money bags? Still filling, filling, Like the horseleech's paunch, and crying "More!"? I'll be thy customer. What rate today?

Not cent per cent, with tenth of gross for premium?

$B e$ reasonable, and I'll deal with thee.

These are hard times, faith.

FEB.

I will not be angry,

Why should I with a rascal? Señor, base fellow, You may go hang or drown-I'll give you naught.

CAB.

No, by mine honor, no, you will not give me, Else should the devil grow weary of the earth. And leave 't to angels. Give me indeed! When pesos Change to perditions, ducats to damnation, Then will I look for gifts. But how now, señor?

'Slid, I believe you are angry!-What's the news?

How fares my little soul, fair Leonor?

Upon my faith, she's an exceeding girl:

What portion will you give her? Sometimes I

Do think of marriage; and hidalgo blood

Has often stooped to gutters.

FEB.

Which is to say,

Your honor might be bribed to marry her?

CAB.

Noble's a noble dower; and so I say,

Verily so, if well thou portion'st her. 
FEB.

Then shalt thou hear it-When she weds a man Like thee, her portion shall be cords and ratsbane, Curses and misery! Oh, thou bold bad man, How canst thou look me in the face, nor think Of ruin'd Ramon?

CAB.

I do think of him, And wonder at the rage that ruins him.

Sirrah!

FEB.

CAB.

Why, how you fume? I come to you

To borrow money-good faith, a thousand ducatsAt highest rates of interest, with surety Of good sufficient names, to be repaid Out of my new discovered silver mine.I say, good names.

FEB.

Were they angelical, Thou shouldst not have a doit to hang thyself.

CAB.

Harkee, old sir-I meant a part thereof To feed thy starving Ramon.

FEB.

Knave, thou liest!

It is to tempt him on to further shame.

To deeper ruin! 
CAB.

Thou art angry,-I forgive thee.

But know, unless thou send'st him money straight, He will be lodged in prison. Ope thy heart;

Send him some gold.

FEB.

Art thou his friend?

CAB.

His best.

FEB.

$<$ Thou lovest my Ramon-ay, and thou lovest gold:>

I'll teach thee how to serve him as a friend, And how to win thee money.

CAB.

Speak that how.

FEB.

Leave Bogota forever; swear me that:

Get thee from hence to Spain; and I will give thee A thousand ducats.

CAB.

Faith, now you speak in jest!

FEB.

I say, I'll give them to thee, nay, and more, Swear me but that, and keep thine oath. 
CAB.
A thousand ducats to leave Bogota?
A thousand?
No, not for five!

FEB.

Wilt thou not go for five?

\section{CAB.}

Art thou in earnest?

FEB.

So may the saints befriend me;

Get thee to Spain; leave Ramon unto me, And thou shalt have five thousand ducats.

CAB.

'Slid!

I take thy offer. Give me the gold.

FEB.

Soft, soft:

I'll have thine oath before a notary;

Find thee conveyance unto Carthagena; Pay thee a portion when thou art embarked, And count the rest, in yearly sums, to thee, Only in Spain.

CAB.

Five thousand on the nail, Paid here in Bogota; to which e'en add A thousand yearly to be paid in Spain, During my term of life. 
FEB.

O grasping villain!

Thou wouldst have all, and yet wilt go with none. If thou wilt more, there's money. in my vaults; Break them, and rob me!

CAB.

$\mathrm{Oh}$ ! dost thou invite me?

FEB.

Rob me, thou knave, that I may have thy life!

Do me that crime, and hang!

CAB.

Most antique churl,

Thou shalt be sorry for this fantasy.

Thou hast no gold for Ramon?

FEB.

Hence, begone!

And a deep curse go with thee, a father's curse!

Get thee to fraud and crime, to theft and murder.

Become notorious to thyself, and sleep,

Dreaming of gibbets, to wake up to racks;

Rob other sires of other sons; bring wo

On other houses; till the general curse

Heaped like a mountain o'er thy head, reach heaven, And wall thee in its fiery hell forever!

Hence, monster, hence!

(Exeunt.)

END OF ACT I. 


\section{ACT II}

SCENE I. A street near MENDOzA's house. (Enter RAMON and PABLo.)

PAB.

I am a poor man, señor Ramon: I must have money.

RAM.

Wert thou as penniless as a beggar, still couldst thou have nothing of me; for I am poorer.

PAB.

Thy father is the richest man in Bogota. He should pay for thy food.

RAM.

Get thee to him, and tell him so. Look, thou insatiate rogue, I have signed and countersigned all thy villainous obligations; I have owned me here thy debtor, and confessed thou canst justly hale me to prison. <What more can I do? If thou canst use these to any honest purposes, or dishonest either, I care not. Get thee to my father. If he will give thee money, I am content; if not, 'tis but a word to the alguazil, and thou shalt have so much satisfaction as my incarcerated misery can give thee.> 
PAB.

Thou knowest I should be loathe to be so unfriendly.

RAM.

I know, thou art as much a cormorant as the rest $<$ and as rapacious for my lean and impoverished body as ever thou wert in my days of fatness. $>$ Get thee away: I have one honest friend left, whom I would not willingly have to see me in thy company.

PAB.

Why, I hope thou art not ashamed of me?

RAM.

No, I am now ashamed of nothing. The grace in me that would have once blushed at unworthiness, is gone; and I have nothing left for contempt but myself-myself. Go, get money, if thou canst; it is thy only hope; thy stay will only rob me of my last. Go, I prythee.

PAB.

Well, God be with you. If I can cheat your father, you shall have some of the gain.

(Exit.)

\section{RAM.}

Thus doth severity still goad me on

Into a hateful villainy; and chains me

$<$ Whate'er my sighs for better liberty >

To fellowship with rogues more vile than I.

Thou drivest me, father, to this noose of shame;

And wilt not bate thy wrath, till I am dead.- 
620 DRAMATIC WORKS OF ROBERT BIRD

\title{
(Enter JuANa.)
}

I looked for thee, Juana! for I knew

Though all else had deserted me, thou couldst not.

\author{
JUAN.
}

Ramon, I have few words to speak to thee:

And even with these, I lay upon my soul

The sin of disobedience.

RAM.

Ay, indeed!

You will obey your sire!

JUAN.

What else should I?

I am his only child; in whom, in sooth, Heaven would not pardon an unfilial act.

\section{RAM.}

Speak boldly; leave me, like the rest, and fear not; Say, Marco is a rich and honored man, And Ramon lost to wealth and reputation:

There's none but will commend thee.

JUAN.

Say not that

Thou know'st, I never loved thee for thy wealth; For, sooth, I liked thee best when that was gone; With thy hard father's heart: and, for thy name, These evil tales destruction speaks of thee, But spur me on to be thy advocate.

I never gave them faith.- 


\section{RAM.}

Lies! that are ever

Writ, by contempt, upon the poor man's brow, But puffed, by flattery, from all jewelled fronts.

But yesterday men found the rich man's son

Worthy and honorable, without stain;

Today they find the fallen outcast's face

Charged with the sinful leprosy of yearsAn hour for transformation!

JUAN.

They will find thee

Stainless again, when thou art fortunate.

Hark to me, Ramon: there are not many days,

Ere I am lost to thee. Unless thou find

Before they pass, some happy road to wealth,

Fortune will come too late to purchase me.

Get gold, and win my father's heart again

Ere he do marry me to Marco.

RAM.

\section{Heaven}

Smite his false, churlish heart!

JUAN.

Do that which shall appease him.

Curse not my father:

RAM.

Marry thee?

He had not thought it without thine own consent!

JUAN.

How thou dost wound me, Ramon! O bright saints, It was but now, as, at my lattice sitting, 
I looked down on the gardens of our sires,

Which, in their days of friendship, our blest childhood,

Did make one common paradise.-I thought

Even of the thousand hours there, hand in hand,

We had roamed among the blossoms. All this time

My father was beseeching me for Marco.

I saw no Marco, at the lemon-tree;

It was not Marco, from the chirimoya,

Had stolen the fragrant buds to crown me with;

It was not he had caught the humming bird,

To keep him radiant in my memory;

I saw naught there but Ramon, and my heart

Even while I wept, was hardened to my father;

And with that sin, and with those tears, I won

A last grace for thee-still a week of trial;

A week wherein if fortune smile upon thee

The rites with Marco shall not be enforced.

RAM.

And how shall fortune smile again?

JUAN.

$<$ I'll teach thee:

Give o'er all thought of mines; they will delude thee On to a golden madness, but no wealth.

RAM.

What else remains? $>$

JUAN.

Thy father,

$<$ Ramon, thy father. $>$

RAM.

My tyrant! my destroyer! 
JUAN.

Speak not thus,-

Though harsh and most unjust, thy father, Ramon!

\title{
RAM.
}

Wed Marco! Now by heaven, not even for thee Will I be spurned again.

\author{
JUAN. \\ Ramon, not spurned.
}

RAM.

Thou dost not know what wrong my sire has done me, This wreck thou seest of what I was, this shred

Of my rent happiness, this squalid relic

Of a once fair and ample reputation, This misery of heart and character-

'Tis what my father makes me! No, thou know'st not The depth of wrong he has done me.

JUAN.

Still remember

What e'er thy suffering, that his wrath, first springing From the base slanders of thine enemies, Thine own rough pride still kindles.

Nay, my Ramon-

I know his nature; and, though much incensed, His heart is yearning to forgive thee.

RAM.

I have found it so! 


$$
\text { JUAN. }
$$

Thou didst not personally

Sue to him. Go thyself, go-send no more Thy friend to him. I like not Cabarero; I fear he is not the true friend you believe him. Go to him, Ramon, and beseech his pardon. Think, if thou gain'st him, thou gain'st me.

\section{RAM.}

This day already did I go before him.

Well, well-

He frowned and passed me by; and, as to mad me With the extreme of most vindictive wrath, Did while I stood hard by, advise thy father To marry thee to Marco.

JUAN.

There is no hope!

$<$ Then heaven help m

RAM.

Perhaps I'll find a mine. $>$

JUAN.

Alas, once more, once more beseech him, Ramon. Seek him alone, humble thyself before him. I will beseech him too. It cannot be, He has learned to hate thee. I will aid thy suit. Once more, once more, or I am lost forever.

RAM.

Well, well, I'll think of it.-But wed not Marco. 
JUA N.

Not till the week be o'er; but after that

I have sworn to do my father's bidding.

'Twas by that oath, I gained this week for thee.

(Enter MENDOZA.)

Alack, I am torn from thee!

\section{MEN.}

What, silly girl!

Get thee to house. Thou wilt not win this puppet By wooing her i' the street. One last word, señor, A week hence is my daughter's wedding dav.

(Exit MENDOZA, with JuANA.)

RAM.

If I do go to him, he will not hear me-

A week?-Nay, though with tears I should conjure him

Ere he have brought a smile upon his face, New words of new misdeeds will turn its light

Into a fiercer flame: he must needs find

Fresh stains of degradation-I will not go.

If he have thought to pardon me at all,

I'll know't by Cabarero.

(Enter CABARERo.)

RAM.

What said my father?

$$
\text { What, Antonio? }
$$

CAB.

Your father? Humph!-Is Febro your father? I think we have all along made a mistake. What 
said he? I am afraid it will not comfort thee to hear. We will not talk it in the street; thou wilt relish it better over a cup of wine.

RAM.

He has rejected my suit?

CAB.

Wilt thou hear how? Let us begone to Pablo's; for, I swear to thee, rage and despair are making me very thirsty.

RAM.

He will give me no relief?

CAB.

Wilt thou search my pockets? I offered him good security. It is true, the names were not so honestly written; but he asked not to see them.Not a penny, not a penny; not even to save thee from perdition.-Pho, how thou sighest! Come, shall we go to drink? Humph!-if thou knewest how foolish 'tis to be melancholy.-Now have I been thinking, a quarter of a minute, how much thy silly face looks like an epitaph-a morsel of silent lamentation over thy dead and buried hopes. Well, thou art content to give up Juana?

RAM.

Because Febro, the broker, loves me not!-I will call him father no more.- He would neither lend to you, who could give him the securities of law; nor to me, who have some of the claims of nature? 
CAB.

Not a penny. 'Sfuries, had you but seen how he reviled me like a dog! And the more I begged him in thy name, the more wrathfully did he abuse me. Lend thee money? said he; I will lend thee the pangs of purgatory: Lend thee money! I will lend thee the whipping post. Thou know'st he was thy father, otherwise I had pulled him by the beard. Send me then comfort to thy afflicted and perishing son, quoth I, with a moderate supplicatory air. I will see him jailed, doomed and hanged first, said he.

RAM.

He did not say this?

CAB.

Oh, not in such brief measures, to be sure: but that was the end of a ten minutes' malediction.

RAM.

$<$ Why then good luck to him and no more begging. Whose throat shall we cut? Money must be had.

CAB.

Thy father has most shamefully treated thee, that's certain.>

RAM.

I will forget it when he has driven me to the grave, not sooner. Money must be had-and within a week. Men have been guilty of parricide. <Money. money! Have you no money? 
CAB.

Here is a handful [of] shabby pistareens, if thou art famishing. Let us go and drink a toast to Marco's fair wife. $>$

RAM.

Shall we hang, drown, rob, or commit murder? I will now do any villainy thou canst recommend me.

\section{CAB.}

Most unnaturally wronged, and unnaturally abandoned. This should excuse any vengeance. Thou must do thyself right. And thy milk-faced brother shall have thine inheritance! Thou must right thyself-

RAM.

Before the week end; or I am in prison, and Juana married.

\section{CAB.}

I could teach thee a way. Come let us begone. 'Sblood! are there no scavengers? - What have we here? By the mass, a key! Now might this belong to a rich man's door, and-

RAM.

Hah!

CAB.

Why what is the matter with thee? Is it gold? a basilisk? 
RAM.

The lost key of my father's vault!

CAB.

Ho, have the saints forgot thee? Why, here is vengeance! wealth! Juana!-It is not thy father's key?

RAM.

I have handled it a thousand times! 'Twas lost a month ago.

CAB.

$\mathrm{Ha}$, ha! thy father bade me rob him! Give me the key. Look-thou art poor, miserable; this will make thee happy. Did destiny put it under thy foot for nothing?-Hark'ee-this is the true mine! Come, Juana is waiting for thee! A little wine will put thee out of this stare,-and this will help thee to thine inheritance.

(Exeunt.)

$<$ SCENE II. The street before FEBRo's door. (Enter LeONoR and Fernando.)

FERN.

Trust me, sweet Leonor, I have good cause To hide me from thy father.

\section{LEON.}

It is no cause

Of a good man, that makes him shun the good. 
FERN.

The best, that have infirmities, are worst Under their proper passions; and the foible, Which, in thy sire, to other men, seems harmless, May make him, in mine eyes, detestable.

LEON.

What is ' $t$ that makes you say so? If indeed, As I will not believe, thou lovest me, My sire should seem an angel in thine eyes.

\section{FERN.}

And so he should, did I not know, in his, My own poor image would be devilish.

LEON.

Well, I care not. You will be sorry soon, When I am wedded to another.

FERN.

Wedded!

You do but tell me this to mock my heart. Then laugh me out of sorrow.

LEON.

No indeed:

'Twas but this morning that my father said, I should be married to Don Baltasar.

And I do think, because you will not do As love would still have taught you, for my sake, It will be best to marry Baltasar.

FERN.

To marry Baltasar! You cannot think To be so false. What, wed? and Baltasar? 
LEON.

He asks my father for me.

FERN.

So would I;

But that I know, the answer to my prayer

Would be, the curse to look on thee no more.

\section{LEON.}

Not if thou beest an honest gentleman.

\section{FERN.}

Honest I know not, for this love might seem To my stern father, subtle and deceitful; But so far honest, I would rather give These limbs up, to be torn by wild horses, Than ever do thee wrong. Sweet Leonor, Know, if I seek thy sire, he will demand me My father's name; whereat I needs must speak Such hateful syllables, as will turn his heart As by a fiendish magic, into coals; And if he do not kill me (as, indeed The sudden pang of rage may urge him to) At least, he'll drive me from thy face forever. I am the son of his worst enemy.

\section{LEON.}

Alas, he has no enemies. I ne'er heard him Speak of an enemy.

\section{FERN.}

The fiercest rage

Hides, like the wolf, from daylight; the rough vulture Asleep upon his perch, doth seem as harmless 
As the poor innocent dove that's nested by. And Febro, brooding o'er a secret hate, May veil his anger with a face of peace. Why should he speak of enemies to thee?

\section{LEON.}

Art thou indeed his enemy?

FERN.

No, not I.

I did forget the rage my father taught me Soon as I looked on thee.-Wed Baltasar?

LEON.

I will not marry Baltasar.

FERN.

But lo,

Thy sire will have thee forced.

\section{LEON.}

What shall I do?

Some maids would be so silly, they would fly If much persuaded.

FERN.

If thou look'st upon me

Howe'er my fearful thoughts may start at folly I will persuade thee.

\section{LEON.}

Not unless he force me!

He'll ne'er forgive me. 
FERN.

O thou simple sweet, If thy sire foam, mine own will anger more. But we'll forget them.

LEON.

Come to me again, And then perhaps I will-And if I do, My father will be so lonely. But then indeed He will forgive my brother: and, with my brother, He will be happy! yes, indeed, more happy Than with poor me.

FERN.

Thou dost persuade thyself; And, in thy arguments, I am resolved. We will fly.

LEON.

Not till he force me!

FERN.

Shall I wait?

Till thou art married? Get thyself prepared:

And see thou have not store of bags and boxes, As will o'erload a caravan of mulesTonight I'll come for thee.

LEON.

No, not so soon.

Get thee away. There comes my brother Francisco!But come to me-yes, come again, again!

$($ Exeunt $)>$ 
$<S C E N E$ III. A room in FEBRo's house. (Enter FEBRo and Silvano, with books.)

FEB.

That money lent to Tomas Catalan,-

Four thousand marks,-is it not due today?

I'faith, 'twas yesterday. Where is Francisco?

Doth he so slur my books? Why this way was

With Ramon, when he 'gan to change and fall,-

Four thousand marks-Threatened with prison too!-

A good, safe man. - His mother ne'er dreamed this, -

Threatened with prison-penniless-forsook.

Why then perhaps the penance is too sore;

His excellency says it is too heavy:

$\mathrm{He}$ is a good man, and a wise man too.

And it may be, if I deny him more,

Necessity may force him to such guilt,

As will his ancient follies make seem virtues.

Poverty has an angel's voice, to plead

Excuse of sin.-The town doth talk of me,

They call me overharsh; and Cabarero

Says, it is I myself that ruin him.

He'1l lose his bride too. Think'st thou not, Silvano,

I might to Pablo's go, and no man see me?

SILV.

To Pablo's, señor?

FEB.

No, let him come to me. I will do naught to make men stare at me. 
SILV.

The saints forbid! - I think he has not his mind.

Rob him! and go to Pablo's! or have Pablo, That low, base, scurvy rascal, come to him!

\section{FEB.}

Say he be jailed, the lesson then is ended; The foul familiar parts from him; and he Repents him in his bonds. But that disgrace May break his heart: I have known men die of shame. For that, to lofty spirits, is such an air As kills the lusty miner in the rift;

A breath is fatal.

SILV.

Talk you of killing, master?

FEB.

O foolish fellow, why dost thou stare at me?

Methinks Francisco tarries overlong.

SILV.

He comes, sir.

(Enter FRANCISCo, bearing gold.)

FEB.

Get thee hence-look to the door.

Thy duty.

(Exit Silvano.)

FRAN.

Father, I have brought the gold;

An excellent sum too. Shall I to the vaults? 
FEB.

Look, boy, where are thy wits? I find me here Four thousand marks that yesterday were due, And not yet rendered.

FRAN.

From Tomas Catalan?

Father, I saw him yesterday indeed, And he desired me fetch it home today.

FEB.

Why that was well. But wherefore spoke you not? Will you do all and with no word from me?

FRAN.

Father, I told you, and you did consent.

FEB.

Did I so, boy? Ay, now I recollect me,This plague o' the heart doth dull the wit. 'Twas well. And Joseph Lucas, have you heard of him? Is't true his mine is flooded?

FRAN.

Deluged, father.

Utterly lost.

FEB.

And he hath nothing left To pay me back that mine (I think I am mad To lend such sum to any mortal man) That mine of pesos I did lend to him? 
FRAN.

No, nothing, father; he is wholly ruined.

FEB.

I shall be ruined too! Why 'twas a fortune

For any man, a rich and princely fortune:

I slaved out years to win it. I shall be ruined.

I may live to see you brought to want.

FRAN.

No, father.

Lose twice as much, enough remains for us.

FEB.

You will have enough with Ramon's portion!

FRAN.

Father,

Forgive my brother, give my portion to him.-

I will live happy in a monastery,

To know he is content and you with him.

FEB.

Thou art my loving boy!-Get thee to Catalan;

Bring me that money; and when thou hast marked it, And also that his excellency gave thee, Store me both in the vault.

FRAN.

Shall I not have

The masons to wall up the garden door?

The match-key, father, of the outer door,Some rogue may find it. 
FEB.

It is about the house;

I did myself mislay it; and I will find it,

Soon as these troubles vex my mind no more.

But ne'ertheless, we'll wall the door tomorrow.

Get thee away; be swift; and after that

Make haste to mark the coin and store it safely.

FRAN.

Father?

FEB.

What wilt thou?

FRAN.

Father, when I am come

To Catalan's door, I shall be nigh to Pablo's.

FEB.

Ay!

FRAN.

If I might but speak then with my brother-

FEB.

Get thee to Catalan; speak to none but Catalan; And think of none but Catalan. Or indeed, If thou must think of Ramon, let thy dreams Bring thee instruction, and inform thy heart What is the end of disobedience-sorrow, Abasement, shame, neglect, abandonment. Think of thy brother, but be far from him. $>$

(Exeunt.) 
SCENE IV. The street before FEBRo's house. (Enter Mendoza and Silvano.)

MEN.

It is very strange.

sILv.

He grieves, sir, much for his son; and I think that sorrow is e'en setting him crazy.

MEN.

He talked with that debauched fellow, Cabarero?

SILV.

Ay, señor; with the decayed and disreputable hidalgo, Cabarero-about Spain, and Carthagena, and a ship, and five thousand ducats. Señor, would a wise man invite another to rob him?

To rob him?

MEN.

SILV.

He said, there was money in his vaults. He might have told him, he could break in from the garden and the cellar. To be sure he said he would hang him, when it should come to be discovered.

MEN.

I have seen in him no sign of dotage, nor of madness; but this savors of both.

SILV.

And what should make him think of Pablo? He asked me, might he not go to Pablo, and no one see him! 
MEN.

This is still as strange; for Pablo is notoriously suspected to be a rogue.

SILV.

He talked of killing too; <and with poisons as deadly as the foul air of a mine.> Now had he thought of killing Pablo, I should not esteem him so mad; but to think of going to Pablo! That is most lunatic-like.

MEN.

He shall not need that; for, see, here comes the knave Pablo to him.

\section{(Enter PaBlo.)}

PAB.

God save your worship, Señor Mendoza. Good e'en, honest Silvano. Is your master at home?

\section{SILV.}

Why if he be at home, what is that to you?

PAB.

So much that I must even beg of your friendship to be admitted to speak with him.

\section{SILV.}

$<$ To be dinged over the head with an old ledger, or a bundle of ingots? Why thou graceless, besotted vagabond! what puts it into thy mind to think he would lend thee anything? 
PAB.

Why if I have good security, why not? I am as honest a man as another, I care not who knows it. I have business with Señor Febro, your master; and you were best tell him so, for it concerns him to know.

\section{MEN.}

If thou wert not beyond the belief of an honest man thy impudence would utterly ruin the fame of an honest man.> How canst thou have the folly to think that Febro will speak with thee? Pr'ythee get thee gone, ere he come out and do thee some violence.

\section{PAB.}

Who knows? I am here on mine own business; and I will have the law of any one that hinders me.

\section{SILV.}

If thou wilt have the law, it must come to thee in shape of a halter. Go, you rogue, get you gone.-Law! were there any law in Bogota, thou shouldst have been the first chapter of its execution.

PAB.

I will not go till I see Señor Febro; and if you cease not reviling me, you rascal crumb-eater! you doorhinge! you cloak-thumper! you look for an old hat! I'll beat your bones into brickdust. You rascal! You will have me in a passion? You will deny me to see your master? You will call me scurvy names?- 


\section{DRAMATIC WORKS OF ROBERT BIRD}

MEN.

Out, sirrah! will you brawl before Febro's door? See, your insolence has drawn him forth, and now you will answer it.

(Enter Febro.)

SILV.

Ay, now look, you rascal; now you will be talked to.

PAB.

Good, your worship, Señor Febro! I have a message from your son.

FEB.

From Ramon?

PAB.

From Ramon, señor; and this noisy, idle, lick-mouthed platter-monger-

SILV.

Please, your worship, I said you would speak with no such base fellow.

FEB.

You were overforward, sirrah!

MEN.

What, Febro! it is not creditable to notice such a man.

FEB.

Good friend, you shall pardon me-I will be mine own adviser. Señor Mendoza, you are welcome. If you fear the taint of his presence, you can walk by. 
MEN.

(A part to Silvano.)

We will observe this interview from a distance.

(Exit, with Silvano.)

FEB.

Now, sirrah, what message sends Ramon by such a messenger?

PAB.

I hope your favor will pardon me-I have harbored the young señor long.

FEB.

Speak the message, and no more. He sends thee to me for money?

PAB.

Hoping your excellent mercy will pity his misery, which is greater than he can bear, and my poverty, which enforces me to pray your goodness for some relief.

FEB.

Why, what care I for thy poverty?

PAB.

My friendship for the young man has brought me into great necessity; and here he acknowledges, unless I am paid, I may justly throw him into prison. But I hope your worship will not compel me.

FEB.

$<$ A thousand ducats! Thou art a lying knave: where got'st thou a thousand ducats to lend him? 
PAB.

$\mathrm{O}$, there is much of that that was the cost of his food and lodging; and then for the rest, I borrowed it, to help him open his mine. But 'twas opened without profit, the money was swallowed, my creditor is enraged; and now the end is this-I must send Señor Ramon to prison, or go myself which he here confesses, and prays your bounty to protect us both.

FEB.

And hast thou the impudence to suppose I will give thee a penny to save thee from this fate?

PAB.

No, señor, but I think you will do this much to save Ramon-whereby I shall be saved myself. >

FEB.

Do as thou wilt; thou shalt have no money. Put him in prison-I am content. He shall have nothing to keep him from the fangs of thee and thy companions, whom he has chosen his friends.

PAB.

Truly, sir, misfortune is no elector of friendships, as, by mine honesty, I know full well. I am myself forced by my necessities to love men I hate; and surely, I think, Señor Ramon would not, unless obliged by his misfortunes willingly consort with men of my degree. 
$<$ FEB.

Dost thou speak this in honesty and humility? or is it a lure to deceive me?

PAB.

Oh, sir, I have known better days; and therefore do I pity Señor Ramon, because I see him treading the same path of folly, which led me into my present baseness.

FEB.

I have mistaken thee!>

PAB.

I have counselled him, too, against his gambling and his drinking; for, besides that I saw how such courses would utterly ruin him, I had no hopes of ever being paid for the cost of supplying him.

FEB.

$\mathrm{Oh}$, then, if thy interest run the same way with thy humanity, I have much reason to believe thee honest.

\section{PAB.}

Truly, it is a sad sight to see a young man led astray by evil companions-a young man, and good.

FEB.

Young, and once good!

PAB.

I cautioned him that Cabarero was a most dangerous companion; it was no honor to be friends with such a hidalgo. 
FEB.

Thou didst!

PAB.

In faith, I told him, Don Antonio had been the ruin of every young man he had sworn love to; and he might see what good had come of his friendship, when he looked on his own wretchedness.

\section{FEB.}

<Is it possible I have wronged thee so much?> Thou didst tell him this? Well, what said he?

PAB.

He wept, and said, his father's severity had left him no other choice-

$\mathrm{Ah}$ !

FEB.

\section{PAB.}

And swore if thou wouldst forgive him, he would never more speak with Cabarero. But, he knew, thou wouldst not.

FEB.

Tell me the truth, Pablo, and thou shalt not be sorry. Did Ramon say this? What! never more speak with Cabarero.

PAB.

I were but an infidel to belie him-he said this, with many tears-

With tears?

FEB. 
PAB.

Crying, in his despair, it was no matter, thou hadst forsaken him and the sooner his ruin was accomplished, the better; thou wouldst have no more shame, when he was in his grave.

FEB.

In his grave? Is he reduced to this despair?

PAB.

Despair indeed! All last night while Cabarero was drinking, he did nothing but kiss an old rosary, that he wears round his neck, with a devout passion < that nothing but great misery could breed up in a young man. $>$

FEB.

That rosary did I give him, in his youth.

It is enough-he is not all depraved.

Pablo! mine own eyes shall be witness

Of his contrition; and haply, if I find

What thou hast spoken is to them confirmed, Thou shalt have all that he does rightly owe thee, And more, to mark my favor.

PAB.

Please your worship, 'tis very true-A thousand ducats, señor.

FEB.

Till I am satisfied thou shalt have nothing.

Tonight, I'll come to thee, and suddenly 
Appear before him; <when, indeed, if sorrow Be working at his heart, it needs must out Into a bursting penitence. $>$

PAB.

I'll have Antonio set aside.

God bless your worship!

FEB.

That villain!

I have had sinful dreams, and sometimes, almost Have thought to buy some rogue to take his life. $<$ I fear me, Ramon cannot be my Ramon, While Cabarero lives to tempt him.>

PAB.

$$
\text { O, your worship, }
$$

There are men, who for a recompense would put him Out of the way-Perhaps a thousand ducatsAt most two thousand-yes, in faith, two thousand, With some few charges to escape the law, Might have him cared for.

FEB.

Nay, leave him to heaven:

I'll buy no Ramon at the price of blood. <After the nightfall, I will come to thee.> Be sure thou dost not speak of mine intent$<$ Thou shalt have nothing else: speak not a word.> Expect me-Now, away.

PAB.

Will give me no relief? Some little money Alack, your worship To buy the boy a supper-we are very wretched! 
FEB.

What, wanting food? $\mathrm{O}$, heaven, my strictness runs Into a wicked, barbarous cruelty!

Here's gold-Buy food; but say not whence it comes. I'll bear enough to free him from thy hands, After the vespers-Mark me, after vespers. <Away now, thou shalt see me after vespers!> (Exeunt.)

END OF ACT II. 


\section{ACT III}

SCENE I. A room in PABLo's Inn. (Enter CABarero and Pablo.)

CAB.

After the vespers? he will come himself? Every way, this is extravagant good fortune. He will bring gold too? Better still! That gold, were he an angel, shall witness him out of heaven. He shall call me rogue and cur, and such vile names, and not be remembered? he shall gibe me when I offer to ennoble his dowdy daughter? Oh, I have often dreamed how he should repent him!

PAB.

Come, 'slife, this will be too improbable, and dangerous.

CAB.

He would hire thee to assassinate me too?

PAB.

Ay, never believe me else: he offered me two thousand ducats to slay thee. But I told him thou wert my true friend and I would not kill thee for so little.

CAB.

A rope for a dagger! a gibbet for a ditch! Oh, I see him, as in a picture, with the priest at his side, 650 
the hangman at his neck, and the multitude hooting him to the scaffold, and all the while, I am rattling his dollars in my pocket!

PAB.

$<$ I tell thee, I like not this plan. Here are two others: -First-we will take Ramon into our counsel, reconcile him with his father and use him for our banker.

CAB.

Hang him, no: his milk and water cowardice will keep us beggars. If his father forgive him, he will repent and forsake us.

\section{PAB.}

Why, then-as the old man will bring a thousand ducats with him-we may help him to a ditch, and so make sure of that: for otherwise, he will see I am cheating him, and give me nothing.

\section{CAB.}

No killing!-except by the laws. Every way, I assure thee, this plan is the best. It is easiest, it veils us from suspicion, and it makes us most profit. If we are in danger, it is our only safety.>

PAB.

Well, I understand all-But if the viceroy should hang me?

\section{CAB.}

Thou art the king's witness, thy life is secure; 'tis but a week in prison, and thou comest out purified with a pardon. 
PAB.

A week in prison! Before the week is over, they may sift out the truth and give me to Satan.

CAB.

Why, then, we will bribe thee out of the jailer's hands, though it should cost a thousand pesos.

PAB.

That's too much! I will get a man out for half that.

CAB.

Wouldst thou be economical with thine own neck? Thy share shall not be the less, whatsoever be the cost.

PAB.

The story will be too incredible.

CAB.

Is not Ramon a good witness? Who shall resist his testimony?

PAB.

But will he appear?

CAB.

As surely as thou shalt; for he has that baseness of cowardice, he will sell the lives of all his friends, to save the worthlessness of his own.

PAB.

I must have a full third. 
CAB.

A full half! Methinks that were but scurvy generosity to share our gains with this whining, unnatural rogue, who is but the cipher of the triumvirate!

PAB.

I think so too! <'Tis but honest to cheat him who cheats his father. $>$

CAB.

Remember that every coin carries the private mark of the broker; wherefore we must bury it till the hue and cry be over, and then melt it into ingots, as if it came from a mine. Harkee!-we will bury it in two portions, in one a thousand pesos or so; this shalt thou show the officers. But the other thou must swear was hidden from thee.

PAB.

$<$ I warrant me; but if you deceive me, I will impeach you, by St. Geronimo, I will!

CAB.

Fear not; I can do nothing without thee. We will to Spain together.

PAB.

With all my heart, and without Ramon?

CAB.

Oh, he will marry Mendoza's daughter; and in the rapture of his matrimony, what will be the loss of a little money to him? > 
654 DRAMATIC WORKS OF ROBERT BIRD

PAB.

Well, I am agreed: I long for the vesper bell. But remember, I say, Cabarero, no roguery!

CAB.

Not a little, I tell thee: we will rob and cheat like honest gentlemen and friends, < and enjoy our good fortune together. $>$ Come, I left Ramon at the bottle, and now he will be brave enough to lead to the vaults of darkness, or-his father.

(Exeunt.)

SCENE II. A room in FEBRo's house. (Enter LEONOR and FERNANDO.)

LEON.

Pray you, begone; I did not promise you; And if my father hear you, oh, dear saints, I shall have no more peace to stay with him.

FERN.

Wilt thou then stay and marry Baltasar? Now, wert thou half as wise as other maids, Thou wouldst not fright at this brave opportunity, But chain me on the instant. Silly love! Though I am mad enough to fly tonight, Tomorrow may my father's strength prevail, And bond me to another.

\section{LEON.}

Indeed! indeed!

And is there fear your sire will be so cruel? 
FERN.

Nay, very certain. The anger of your father Is but a matchlight, kindling on the instant, And, on the instant, with a sigh put out; But my sire's rage will be a conflagration. $<$ Lit in a mine, and roaring on forever. $\mathrm{Oh}$, could tell thee stories of my sire, And of myself, if so I durst, would make thee Instant and resolute. For know, thou doubter, Whate'er his worth, my father loves me well: And know I not how long I might have courage To act the sin will lose me all that love, And gain me all that fury.> Wherefore, quick! While our fates smile on us, let us begone.

In sooth, 'tis wrong.

\section{LEON.}

FERN.

Why, here's a delicate bundle Might grace the shoulder of a soldier's spouse, As sister to a knapsack.

\section{LEON.}

'Twill break my father's heart.

Alack, for pity!

FERN.

$<$ It shall be mended.

Now, with my life $>$ I'll warrant his forgiveness: Would I could hope my father's! A rogue am I.Thou know'st not at how rich a cost I buy thee. Come, do not weep: I swear, this flight will bring thee Nothing but happiness. 'Tis I alone Will feel the punishment. 


\section{LEON.}

And wilt thou feel it?

I am determined then I will not fly,-

Thus to bring trouble to thee.

\section{FERN.}

$<$ Why, here's a wind,

Fooling the compass! and yet so sweet and pleasant, Breathing the gentle odors of true love, That I'll forgive it. Fear not thou for me; $>$ Whate'er of state and men's consideration, Whate'er of hope, or what of certainty, To rise to greatness, I give up for thee, $<$ I give up with good will-at first, with fear And strong reluctance, but, at this good hour With joy and pride; $>$ for now I know that fate May hide more happiness in a lowly cot, Than e'er the thrones in great men's palaces. $<$ So to a cot we'll hie us, in some nook Of a delicious valley, where the mountains, Walling us in with azure, up to heaven, Shut out all things but heaven. $>$

\section{LEON.}

$\mathrm{O}$, heaven be with me!

I fear to fly. Come thou some other time:

Let me think more of this. Come back tomorrowLet me think more; and, as I think, once more Look on my father's face.

FERN.

A thousand times,

After tonight, for he will soon forgive theeNay, look not back. 


\section{LEON.}

Ah! hark! we are discovered!-

Another time-He is stirring in the vault!

FERN.

Pause not, the door is open.

LEON.

It is too late:

I hear my brother's step! Away, Rolando!

FERN.

This comes of trembling!

\section{LEON.}

Tomorrow night-

FERN.

Farewell, and dream of me.

Tomorrow!

(Exit.)

LEON.

He'll see the bundle!-

\section{(Enter JUANA.)}

My friend and Ramon's love! She saw Rolando!

$$
\text { JUAN. }
$$

Why, Leonor, does no one watch the door? This might invite a robbery.

LEON.

Odd's heart, a robbery! 
JUAN.

And how you tremble!

\section{LEON.}

I am not afeard!

My father is in the vaults; and so I am not Afeard of him or any other man.

\section{JUAN.}

Afeard of him! Oh! you are much confused. Afraid of him! Why, sure it was no rogue, Although, good sooth, he muffled up his face, As he brushed by me-Tell me, LeonorI thought 'twas Ramon!

\section{LEON.}

And perhaps it was-

JUAN.

Was it indeed! and did he see his father? And will his father pardon him?-Oh, for pity! How could it be so, when so timorously He stole away, and stole away from me? $<$ Why shouldst thou hide it from me? $>$

\section{LEON.}

Did you see anybody?

Why Ramon was not here.

$$
\text { JUAN. }
$$

Who could it be?

Sure you are not ignorant, some man-some stranger, Cloaked to the eyes, was stealing through the house? Indeed you should call your father. 


\section{LEON.}

Frightened, I mean-

He would be angry-

JUAN.

Oho! a bundle nicely tied

In a fair Eastern kerchief! and a man

-Stealing away! and then these thousand blushes, And contradictions!-

LEON.

Oh, my dear Juana!

You'll not betray me!

JUAN.

Shall I laugh at thee?

I will not frown; I am not one of those

That step between true hearts, and break them-Go;

Think what thou doest, before thou art resolved;

Think what thou doest, before thou leavest thy father;

Think of him well; think of thy brothers too;

Think of thy lover, is he good and worthy;

$<$ Think of thyself, thy maiden reputation $->$

Think of thyself; then, if thy heart confirms thee,

Follow the guidance of thy love, and go,

$<$ With heaven to comfort thee $-I$ will not stay thee.

I would have no heart suffer, save my own. $>$

But be not rash, be not precipitate:

Methinks your flight would break your father's heart.

LEON.

I will not leave him, for I know indeed, (Heaven pardon me that e'er I should forget it!) $\mathrm{He}$ is wo enough for Ramon. 
JUAN .

Is he indeed?

If that be so, then have I happier hopes To charm his anger into loving pardon.

I came to be his suitor.

\section{LEON.}

\section{Shall I call him?}

And yet I fear to have you pray him now. $\mathrm{He}$ has been vexed a thousand times today. And was a little strange and irritable. These crosses move him deeper than of oldTomorrow will be better.

\section{JUAN.}

Think not so.

The happiness, almost the life of Ramon Rests on a speedy pardon.

\section{LEON.}

$\mathrm{He}$ is in the vault

About some project. If you'll wait awhile, Francisco will come back, and call him forthNay, there's my brother!

\section{(Enter MENdoza and Silvano.)}

$$
\text { MEN. }
$$

It is impossible.

I tell thee, good Silvano,

SILV.

Ask my mistress else. 


$$
\text { JUAN. }
$$

Father!

$$
\text { LEON. }
$$

What is the señor's will?

MEN.

$$
\text { By heaven! }
$$

There's roguery afoot! Where is your father? There are knaves a-robbing him.

(Exit Silvano.)

\section{LEON.}

Good sir, for pity,

What do you mean? My father, these two hours, Has been i' the vaults.

$$
\text { MEN. }
$$

I say it cannot be:

There are ruffians in the garden: by this hand, I saw a lantern twice flash through the trees, Heard voices murmuring and-

$$
\text { (Re-enter Silvano.) }
$$

SILV.

The vault is locked:

Heaven guard him well, my master is not there! I'll to the garden.

(Exit.)

\section{LEON.}

He did not come out!

Perhaps they have murdered him! 
MEN.

What, help! ho, help!

Here's villainy! foul, bloody villainy!

\title{
(Enter Francisco.)
}

O, wretched boy, your father's vaults are robbed, And he perhaps is murdered!

(Exit Fra NCISCo.)

LEON.

Give him help:

$\mathrm{He}$ is old and feeble.

\author{
JUAN. \\ <Do not be dismayed. > \\ (Re-enter SilvaNo, bearing a cloak.)
}

SILV.

Thieves! thieves! we are robbed! the garden gate is open,

The cellar wall broke through, the vault exposed.

\section{(Re-enter Francisco.)}

This found I hanging on a cactus bush;

This morn I noted it on Pablo's back.

I know the robber!

FRAN.

Run thou for alguazils, And follow me to Pablo's-Sister, fear not: The door is locked, my father is not there- 
It is no murder, but a robbery.

Señor Mendoza, will you go with me

Or tarry here, and break this to my father?

MEN.

Nay, I will go with you-Stay with the girl.

(To

JuANa.)

O my life, the strangest marvel! Robbed by Pablo!

We must be quick-A most strange villainy!

(Exeunt.)

SCENE III. A room in PaBlo's Inn. (Enter PABlo, RAMON, and CABARERO each bearing a bag of coin.)

CAB.

Victoria! Thou art revenged, enriched and beatified; the mine is found, and Juana is thine own! We will melt these dollars into ingots, show them to Mendoza, and, tomorrow, thou wilt be in paradise.

RAM.

In hell, I think; for what devil is blacker than I? But he forced me to it!

CAB.

Ay, he forced thee to it.

RAM.

We are followed too; I hear the hue and cry! Let us escape-Do you not hear?

CAB.

I hear the beating of thy silly heart. Why what a cowardly poor-spirited knave hath vile liquor 
664 DRAMATIC WORKS OF ROBERT BIRD

made thee!-Pablo, thou art the king of cheatsWine, and a crucible, and a roaring hot fire-I tell thee, thou art mad! All is safe.

RAM.

Hark, hark, Antonio!

CAB.

'Tis the rumbling of a cart. Fy upon thy white gizzard! Wilt thou never make a rascal of spirit?

(A knocking.)

Hark!

$$
\left\{\begin{array}{c}
\text { RAM. } \\
\text { PAB. }
\end{array}\right\}
$$

\section{RAM.}

We are lost! we are lost!

CAB.

$$
\text { (To Pablo.) }
$$

Down with thee to the door, and be wise.

\section{(Exit Pablo [CABarero hides the gold].)}

\section{RAM.}

We are undone!

CAB.

I will stab thee, if thou goest on with this clamor.

\section{RAM.}

Antonio! 
CAB.

Art thou not now a rascal? and why shouldst thou not have the wit and courage of a rascal? Put on a face of iron, and harden thy nerves into the same metal.-This is a friend-Lo, he comes to spy on thee!

(Re-enter PABLO, conducting FEBRO [FEBRO bearing a bag of coin].)

He can never forgive thee now, remember that.Good even, Señor Febro, you are very welcome.

\section{FEB.}

Away, bad man! I'll have no words with thee. My office here is full of love and peace. And hath no part in thee, except to steal A victim from thee. Hark thee, Ramon, boy; Thou once wert good, and dutiful and lovingLoving, I say, and then, besides, thou wert The first life of thy mother. What thou wert To mine own old affections, I'll not speak. Thou hast acted many follies; yet, because <Of mine own weakness, and because I know > They have weighed thee down with heavy misery, I am willing to forgive them.

RAM.

Hah!

FEB.

$<$ Forgive them! $>$

One thing alone-and if thy heart yet holds

A grain of love, it will not start at that;

$<$ One thing alone will bear thee back again 
Into my house-perhaps my heart too. $>$ Bid Farewell unto this man, who loves thee not: Know him no more; and here am I to free thee From his bad thraldom-Look, I have gold with me. (Displaying a bag.)

Enough to ransom thee.

RAM.

What, gold!

FEB.

I heard

How far thy miseries had carried thee.

RAM.

What gold? hah! gold for me?

FEB.

Thou seest! enough Perhaps o' the present, to discharge thy debts. And make thee good and happy once again.

RAM.

$\mathrm{Ha}$ ! ha!

Thou couldst relent then? Why thou art gone madThou bring'st me money! It is too late.

$<$ CAB.

(A part to Ramon.)

Well said!

Thou art a man. He waited his pleasure. What has he made thee? $>$

FEB.

Ramon, my son! 
RAM.

Oho! thy son!

Why what a father had that son? a father Who, while forgiveness would have wrought the son Into a holy penitent, gave him wrath, And turned him to perdition-What a father! To do this mischief to his child; and when He saw his child i' the gulf of hell, to taunt him With words of pardon!

\section{CAB.}

\section{Bravo! a proper spirit!}

Thou seest, old man! thou wouldst not hearken to me. Oho, I begged you; but you called me rogueVillain, and rogue.-

FEB.

Ramon, thou knowst not what thou sayest. Perhaps I was too hard with thee; but I repent me, Wilt thou have pardon? love and pardon?

\section{RAM.}

Curses for pardon, and a knife for love!

Yea;

I am not thy son; the thing that was thy Ramon Is perished! lost, forever lost! no atom That once was his, left breathing,-all destroyed, And made the elements of fiends-Oh, hence! Away! old maniac, hence!

FEB.

And listen to my boy?

Do I live 
PAB.

Hark!

VOICES WITHIN.

Thieves!

FEB.

$\mathrm{O}$, heaven,

Thou judgest sorely! Is it so indeed?

Would I had died or ere I heard these words.

These worse than death! Well, God be with thee.

Ramon:

Thou hast killed thy father.

VOICES.

Thieves! thieves! thieves!

(Enter Francisco, Silvano, Mendoza, with Alguazils. As they enter, CABARERo seizes upon FeBro.)

CAB.

Stand fast!

Old rogue, dost think to 'scape! The laws will have thee.

The laws, I say, hah!

FRAN.

Father!

CAB.

Off, thou cub!

Touch not the rogue. Your prisoner, officers!

Febro, the robber of Febro! 
FRAN.

\author{
Villain and fiend! \\ (He is held.)
}

FEB.

What is the matter, son? Will no man drag

This fellow from me?

CAB.

A felon knave.

Your prisoner, officers!

FRAN.

$\mathrm{O}$, father! father!-Brother!

Why don't you speak? Why don't you kill the villain?

CAB.

(A part to Ramon.)

Away with thee!

(Exit RAMON.)

Your prisoner, officers! .

Whom I do here accuse, with witnesses

More perfect than myself, of robbery

And fraud upon his trust. And here you have

In his own hands, part of his felony;

And, there i' the corner, more of his vile crime.

FEB.

Thou raving ruffian!

MEN.

What, Antonio?

Chargest thou Febro with self-robbery?

FEB.

Why, who is robbed? 


\author{
FRAN. \\ O, father!
}

CAB.

It shall be proved.

PAB.

I claim the royal mercy.

MEN.

Shake off this stare, Art thou insane? They do accuse thee, Febro, Of robbing thine own vaults.

FEB.

\title{
Do I not dream?
}

MEN.

$<$ Thy doors are broke.

FEB.

I am ruined!

CAB.

It shall be proved before his excellency, Perfectly proved, with witnesses enough. Here's Pablo, his accomplice, has confessed.>

FRAN.

O, father!

FẺB.

Robbed? 
CAB.

$<$ Take him before the viceroy-

FEB.

I'll have the villain for ten thousand ducats:

I'll have it proclaimed.

FRAN.

$\mathrm{O}$, father!

FEB.

Robbed?

CA B.

Away? >

- He apes amaze. Carry him to the viceroy. It shall be proved before his excellency.

[A LL.

Away! Away! Away!]

(Exeunt [Omnes. FEBro in the hands of the Alguazil.].)

END OF ACT III. 


\section{ACT IV}

SCENE I. A room in the vice-regal palace. (Enter the Viceroy, attended.)

PALM.

They are insane that say't-the broker robbed! And Febro turned a rogue! Now surely madness May sweep o'er nations like a pestilence, And folly, like a corporal epidemic, Fever the minds of all. What is't but madness, Could fill the city with this riotous cry, Febro is robbed. Febro hath done a fraud? $<I$ know the man-sure of all men most honest, And-I did think-most cautious. Yet it may be, As my fear whispers me, he has been robbed, And those-I know, I feel, how that may beThose who have suffered in his losses, raise, From grief and rage, the cry of villainy $\rightarrow$ What! do they bring their fury to the palace?

IST OFFICER.

Even so, your excellency; they have dragged The broker to the gates, and cry for justice.

\section{PALM.}

Justice for all! Set them before us straight. That he who needs it most, this poor old man, May be protected from the accusers' rage, And they be taught how foolishly they wrong him. 
(Enter Cabarero, Ramon, Mendoza, Francisco, with Officers bringing FEBRo and PABLO. CABARERO. and some others, crying Justice! justice!)

\section{PALM.}

What now, ye violent and thoughtless men, What crime you are committing, know you not, Thus, with rude hands, dishonoring the body, And, with rude tongues, the name and reputation, Of a most honest worthy citizen?

CAB.

Your excellency is deceived; this man Is a most subtle and confirmed rogue, $<$ As will be witnessed to your excellency.

PALM.

What, Febro! dost thou hear? What means this charge?

Why do I find thee thus? $>$

FRA N.

Oh, noble viceroy,

Punish these men, that, with such slanderous hate, Destroy my father.

CAB.

The prisoner, please your highness, Has been discovered in a knavish fraud.

PALM.

Hold thy peace, yet.-What, Febro 
FEB.

I will speak-

Thou rogue, I'll have thee howl! Ay, by my troth, And every man of them. Are they all crazed?

$<\mathrm{Oh}$, I am glad to see your excellency-

These rogues! these rogues! $O$, but that I have lost

My faculties in wonder, I could speak

Till they were struck with shame. What is the matter?>

Their cry is, I am robbed. I know not that;

$<$ Pray you discharge me, let me see to it.

I cannot think't; and yet it may be so.

I may be robbed (heaven pity mine old age!)

And many wronged with me-But 'tis not that.>

What do they mean? I pray, your highness, mark them.

They charge me with dishonest practices.

Dishonest practices! If there be law,

I will have vengeance on them.

PALM.

So thou shalt,

To the extreme of justice-Good Mendoza-

Thou art the calmest here; speak what thou knowst Of this same robbery. Is there a robbery?

$<$ Hath any man been spoiled of property?> Have Febro's chests been broken?

MEN.

Please, your highness,

'Tis even too true; and true it is (I say it

With shame and sorrow, and with much amazement)

There are particulars of damning moment,

That show connivance where one would not think it. 
FEB.

By heaven!'tis false! Who is there could connive Of all my house? Will any say 'twas I?

$<A y$, they do say it; they do charge it on me!> Pray, good your excellency, search this well; $<$ Pray you, be quick, and let me know it all. There is some plot against me; I am robbed. Well, is not that enough? I am then ruinedIf robbed, why ruined; for, of all still left, There's not enough to cover o'er that loss. That will bring many into need. Search well; > Find me the rogues, and give me back my gold; I can with that pay all, and more than all.

PALM.

Febro, I pity thee.-this looks not wellSay'st thou, connivance? <In some hour of madness, Spirits of virtue have themselves forgot, And, in one deed, turned villains. $>$ Speak, Mendoza. Utter the charge, if charge thou hast to make; $<$ Tell me thy tale, if any wrong thou know'st; > And, in my quality of arbiter, I will forget who is the man accused, And judge him as a stranger.

FEB.

Let him speak;

I do defy him; let him speak; let all.

All men, my foemen and my friends alike, I do defy to speak a wrong of me!

\section{$<$ MEN.}

Until today, I dreamed no wrong of Febro; Nor, please your highness, could I dream it now, But that I think he has not his proper mind. 
FEB.

Why that may be; you keep me still bewildered, Knowing myself all ruined, but not how; Traduced, maligned, but wherefore ignorant. Despatch, Mendoza, for I have no fear. You will be sorry to have thought this wrong. Not in my mind! In sooth, you do distract me.>

\section{MEN.}

Please, your excellency.

Pablo, the innkeeper, here throws himself On the king's mercy; and, himself avowing Accomplice in the act, Baptista charges To have been his leader.

\section{FRAN.}

Oh, your noble highness,

This is an open villainy. That Pablo Is a notorious rogue, <a thief and liar, > Not to be hearkened to by honest men.

PALM.

Silence, Francisco; be not overrash; Thy father shall have justice.

MEN.

Noble sir,

What the youth says of Pablo is most true; No honest man should hearken to his speech; Yet Febro spoke with him, and I myself Witnessed the conference.

FEB.

I spoke with him.

Why, so I did; 
PALM.

be with thee!

Peace, Febro, Heaven

$<$ This is a cloud that gathers to a storm!> He spoke with Pablo?

\section{MEN.}

Yes, and gave him money.

His man Silvano there stood at my side, And watched him with me. <At my words of wonder, (For truth 'twas wonderful to see the broker In earnest speech with such a man as Pablo) Silvano $>$ [and] told me how, short time before Febro demanded, if he might not steal To Pablo unobserved; and did assure me He feared his master was not in his mind; Wherefore, in proof, he told me how, before, Febro had talked with señor Cabarero Inviting him to robbery and flight, And such wild things as surely proved him mad.

CAB.

Put me on oath, and let me swear this true.

FEB.

Why this is true.

FRAN.

$\mathrm{O}$, father! father!

PALM.

Febro!

FEB.

I say 'tis true; where is the need to swear it? 
678 DRAMATIC WORKS OF ROBERT BIRD

PALM.

Febro, be wise;-I pity thee.

FEB.

I never

Thought to conceal it. Without fear, I own it;

I talked with Cabarero, and did urge him

To rob me.-

CAB.

He confesses!

FRAN.

Pray you, stop him:

He knows not what he says- $O$, father!

FEB.

Boy,

Did I e'er teach thee then to lie?-I own it

I bade him rob me, <at the evil urgings

Of my bad fancy; $>$ for I hoped that act

Might bring him to the scaffold; and I thought,

If he were dead, Ramon, my outcast Ramon,

Might be mine own again.

CAB.

Now by my faith,

That Ramon, whom he seems to love so well, He kept in want and misery, and knew it. For Ramon I besought him, he denied me. He owns the urging - ay, he urged me sore. I will not say with what rich tempting offers. In sooth, I thought him mad; for wherefore should he, 
In his old age, invent so wild a fraud?

'Tis true, he had had losses-and perhaps

These same had turned his brains; wherefore I hope

Your excellency will be merciful.

Sure he was mad; though subtle and discreet

In the vile plan he showed me.

FEB.

$\mathrm{O}$, thou villain!

I am sorry I did spare thee. For a little I could have bought thy life.-Your highness hears him!

CAB.

Your highness hears him! Pablo will confess He would have bought him to assassinate me. It was not safe for him to have me live;

But nevertheless I bring not that against him.

FEB.

It is not true; and Pablo knows I told him, We would this bad man leave to heaven.

PALM.

Still Pablo!

And wilt thou still, unhappy, Febro, darken Thy hope by such admissions? What, indeed! Hold speech with Pablo? and on such black subjects? Talk with a wretch about another's murder?

FEB.

I talked with Pablo; will your highness blame me?

It was of Ramon, and his miseries;

I gave him money too-it was for Ramon!

I sought his house, but it was still for Ramon! 
CAB.

And Ramon should have been his accessory!

(Apart to Ramon.) Peace, <on thy life!> There is good proof of this;

Will not your excellency list to Pablo?

The bark was ready on the river; seek it;

It waits for Febro-Pablo can speak all.

\section{PALM.}

He shall be heard. Speak thou again, Mendoza.

I am amazed and shocked. What know'st thou more, To make this madness yet more probable?

\section{MEN.}

My terrace roof o'erlooks Baptista's garden.

I sat above, to breathe the vesper air;

And twice or thrice, I marked a glimmering lamp

Among the shrubs, and, in the end, a light

Flashing as from an open door, where was

No door, save one ne'er opened. <This thing moved me;

And giving all my faculties to watch, Forthwith I heard low murmurs as of voices, And, once or twice, the crashing of men's feet Along the pebbled alleys. > Straight I ran To give the alarm. Febro was in the vault, And all the evening had been; so I learned From his affrighted daughter, who was sure (And so Silvano) he had not passed out.

Judge my surprise to find the door well locked, And Febro vanished! how, but through the door That opened on the garden? and with what, Save the rich treasures which were there no more? 
FRAN.

Alas, the key that oped that garden door, Was lost a month ago; and my poor father Tomorrow would have walled it up.

PALM.

Tomorrow?

For a whole month he left his vaults exposed? This-Leave the substance of confiding men To a month's accidents and knaveries!This looks but darkly. Speak; what more, Mendoza?

MEN.

Some wild words dropped from mine own daughter's lips:

She had abruptly visited the house, And stumbled on a man close muffled up, Who brushed by her, and fled; and, in addition, Found Leonor confounded and perturbed, Her mantle in her hand, and at her side A bundle, seemingly prepared for flight.-

FEB.

My daughter! If thou beest a man and father, Discharge me straight, and let me save my child. That slave Rolando! O, I see it now; $\mathrm{He}$ is the rogue! 'tis he has broke my vaults, And steals my girl away!-Let me begone. My Leonor!-I'll give you up my life, If you seek that; but let me save my child!

PALM.

Stay. My heart bleeds for thee. I cannot free thee. This charge is heavy, and most like to truth. 
FEB.

You have no heart!- Francisco, you are free;

You have not robbed, nobody calls you rogueGet thee to home, and to thy sister.

FRAN.

Father!

FEB.

Save me thy sister, or I' 11 live to curse thee(Exit Francisco.)

I thought your excellency was a man!

You gave me friendship too.

PALM.

I did, Baptista, And will-disprove this fearful charge.

FEB.

My child!

You keep me here, to set me mad with charges That make me seem a rogue; and all the while Dishonor seeks my child-A step might save her!

MEN.

Let him be satisfied; his girl is safe; I left Juana with her.

FEB.

Heaven reward thee!

I will forgive thee all thou hast said against me. She has not fled! How could I think she would? Fly from me in my wretchedness! and with The man that robbed me! 
CAB.

Is not this well carried?-

\section{(A part to RAMON.)}

Hold up thy head-Thou seest how fortune helps us.

\section{PALM.}

Hast thou still more, Mendoza?

MEN.

\section{Silvano here}

Picked up the cloak of Pablo.

PAB.

I lost it in the garden.

$$
\text { I am guilty, }
$$

MEN.

But little more

Have I to say, but, haply, that most fatal.

With officers, we followed to the inn;

And there, in the hands of Cabarero, stood

Unhappy Febro.

FEB.

Ay, most miserable!

$<$ Ramon, why didst thou say those things to me?

I think they have turned my brain!

MEN.

Wretched Baptista;>

With still, even in his frightened grasp, a bag Of the same coin that had that moment vanished. 
FEB.

I took it there-Why look ye thus upon me?

I bore it with me to redeem my son.

CAB.

Ay, sooth, with three bags more!

(A part to RAMON.)

Think of Juana!

$<$ This thing is for a time. $>$ Señor Mendoza

Will say he found them: faith, 'twas Pablo brought them.

I can attest how this was all discovered.

\section{PALM.}

Mendoza, is this true?

Here is the gold.

$$
\text { MEN. }
$$

Indeed most true;

PALM.

What fiend possessed thee, Febro?

FEB.

Well, do you judge it true? How got it there?

I do not know; I took but one bag with me, To save my boy.

PALM.

Whom didst thou counsel with? Alas, all weighs against thee. Hadst thou spoke But to thy daughter, or thy man, of this. 
FEB.

I spoke with none: and wherefore should I speak?

Will Pablo charge me? Pablo did deceive me;

He told me lies of Ramon.

CAB.

There again!

He told some truths-he told where they had hid Their ruffian spoils.

FEB.

He did! and are they found?

All will be well again! Confess all, Pablo, Where didst thou hide the gold?

PALM.

Here see the wanderings of a dotish man, $<$ Now, but that I I should pronounce this folly innocence. Febro, attend: thy star is darkening fast; And the old trunk, whose wealthy branches hid The secret rot that hollowed at its heart, Is trembling in the tempest: lo, the bolt Comes to the earth, and hisses at thy front A moment, ere it fells thee. $>$ Speak no more, If not more wisely-Thou, Mendoza, art, In all thou hast said, confirmed?

MEN. I am.

PALM.

And thou, Antonio, on thy hopes of heaven, Speak'st but the truth? 


\section{CAB.}

I do.

\section{$<$ (A part to RAMON.)}

Shudder no more. $\rightarrow$

And Pablo will swear all as I have said.

If they do find the gold he swore they buried, 'Twill show his truth.

MEN.

They have already found it;

Yet a small part alone-some thousand ducats.

\section{PALM.}

Thou swear'st this, Pablo?

PAB.

I hope for mercy!

Yes, your highness, yes:

PALM.

Tell mine officers

Where lie the greater profits of thy crime.

PAB.

I know no more; I left the bags with Febro, And him i' the garden, that I might straight bury Mine own share in the place whereof I told them. As for the rest, good faith, I know no more; Febro had charge of that.

FEB.

Now, were heaven just, Thou shouldst die with this slander in thy throat, 
Monster of falsehood! Has it come to this?

Is't true? is't possible? a man like me, Old,-in the twilight of my years, and looking Into the dusky midnight of my grave,An old man that has lived a life, whereon No man hath found a stain $<\mathrm{Oh}$ ! you are mad, To think this thing of me.> A fraud? a fraud! What! I commit it? with these gray hairs too? And without aim,--save to enrich this rogue, That swears away my life?

\section{PALM.}

Aimless, indeed,

Unnatural, and most incredible;

And therefore easily disproved, hadst thou

One proof beyond its wonder. < Give me proof;

Discredit not this knave, I know him well;

But show thou wert not with him,- - or for what;

And hadst no gold with thee-or wherefore hadst it;

Or do what will be better for thy soul,-

Rouse from this dotish fit that has transformed thee, $>$

Repent, confess, deliver up the spoils

$<$ Of thy unhallowed avarice; and, in memory

Of thy once stainless fame (no more unsullied) $>$

And in regard of years that should be reverend, In pity and in peace, we will discharge thee.

\section{FEB.}

I do repent me-of my miseries;

I do confess-that I am wronged and lost, Robbed, and traduced, and by collusion slain, Trapped by false witnesses, and by an unjust judge Unrighteously condemned. 
PALM.

Say'st thou, Baptista!

"An unjust judge?" "unrighteously condemned?" What say the witnesses? thy friend, Mendoza?

Will he traduce thee? What Antonio here?

Does he gain aught to harm thee? What this Pablo? Who prates his own life into jeopardy?

And what-By heaven, I would have spared thee that! -

What says thy son?

FEB.

My son! my Ramon! Ay, let Ramon speak,Hah! what! does Ramon charge me?

PALM.

Hear'st thou, Ramon?

CAB.

$<$ (A part to RAMON.)

Wilt thou be ruined?>

FEB.

Ramon?

PALM.

Dost thou see!

Horror hath made him dumb. Had he a word To aid thy misery, he had spoken it.

FEB.

Dost thou accuse me, boy? I do defy thee! What! swear against thy father? Ope thy lips; 
$<$ Speak what thou canst. Oh, now I have been $\operatorname{mad} !->$

Thou know'st full well for what I sought thee out.

Why art thou silent? <Lo, a word of thine Would clear up all; speak thou that word. Accuse me? My son accuse me? $>$ By the curse, not yet Uttered nor thought of-by the father's curse, That will convert thy bosom to a hell, $\mathrm{Ne}$ 'er to be quenched by penitence and prayers, Speak, and speak truly.

\section{PALM.}

Stand aside.

FEB.

$\mathrm{Ha}$, ha!

One word clears all; and he will speak it. Hark!

(RAMON, endeavoring to speak, falls into a swoon.) My son! my son! oh, you have killed my Ramon!

\section{PALM.}

'Tis thou hast done it. <What! though thou wert so cruel,

Though thou hadst driven him from thy roof and love, He could not speak the word that should destroy thee.>

Bear him away; his silence speaks enough, I will not force him to unlock his lips, In the unnatural charge.

(RAMON is led out.)

Art thou content?

All speaks thy guilt. Confess; repair thy fault; Disgorge thy spoils. 
FEB.

Do with me what you will, You have robbed and ruined me among you all, $<$ What care I now how soon you take my life? > You make me out a felon, and have turned,Heaven plague you all-have turned my children 'gainst me.

PALM.

Obstinate still? Confess, and take our mercy.

FEB.

The mercy of oppressors! Heaven confound you!

I know why you condemn me, ay, full well:

$<$ I could have paid you all-I have claims yet; > You kill me for your losses.-When you will:

The grave is quiet, and Heaven will yet avenge me.

\section{PALM.}

Amazed and sorrowing, we pronounce thee guilty Of a most mad, most base, and wicked fraud, For which our laws of Spain demand thy life. Yet, in respect of thy augmented years, We spare thee that. Depart; live and repent thee. What property still openly is thine We seize for benefit of the many wronged. We give thee life, but judge thee ignominious. And to remain in ward of officers, In thine own house, till all be satisfied.

FEB.

Why you were better take my life at once; $<$ You leave me naught to feed me! and > the air 
You grant me leave to breathe, is but the poison Of a corrupted reputation. Kill me;

What matters it? Your mercy is a name For a new rack, wherewith you will torment meThe rack of shame and pitiless degradation.

A rogue!-a felon!-

(FEBRo is led out.)

PALM.

$<$ Poor wretch! I'll think of thee'

I have a dream-and though all seem to speak thee

Dotard and knave, it shows me other things But hide them yet.

CAB.

May it please your excellency,

Permit me to depart, and look to Ramon, A very unhappy man.

PALM.

Away!

(Exit Cabarero.)

PALM.

Thou, Pablo,

We do adjudge to prison, to resolve

More fitly of thy fate.

PAB.

I claim the royal pardon.

PALM.

I'll find if thou hast won it.

(PABLO is led out.) 
Look to it, officers: this man, Antonio, Watch strictly; have him ever in your eyes; Give him no passage from the gates. For Pablo, Fright him with words of death, and find what secrets May drop from terror. Watch me Ramon too.

I have strange fancies, - but these hints will serve you. Mendoza, have thine eye upon Baptista;

What misery may come to him thou know'st;

Let him not want, nor let his children suffer.

What cost soever thou art at to help them,

I will requite thee; look to them tonight;

Tomorrow come to me again; I have

A thought to hold discourse on-but not now. $>$

(Exeunt.)

$<$ SCENE II. The street before the Palace. (Enter CABarero and RAMON.)

RAM.

The Viceroy has given him his life? Well, I am glad of that.-Else should I have confessed all. His freedom too!

CAB.

Ay, I tell thee,- -his life and freedom,-all which is contrary to law.- Such a fraud is a matter for hanging.

RAM.

And thou thought'st, when thou persuadest me to witness against him, that he should die!

CAB.

By my faith, no:-I knew his life was in no danger. I told thee the Viceroy was too much his friend. 
RAM.

He will come to want, Antonio! We will send him money.

CAB.

'Slife, this is superfluous-and full of risk.

RAM.

I tell thee, he shall have money and relief, though it bring me to the gallows.

CAB.

Wilt thou be wise?

RAM.

He was coming to me with pardon! With money to relieve me! and with that money did I witness him to destruction.

CAB.

Foh! thou said'st not a word.

RAM.

Hah! that's true: no man can accuse me-I said nothing against him.-But my silence-my silence damned him, and it damns me. There is no fiend like to me. Witness against my father! Kill my father!-Cain killed his brother, and his forehead was marked with the finger of God. -I-I-What is justice? I have no mark, who have killed my father!

CAB.

Faith, not a jot-there is no mark about thee.- 
694 DRAMATIC WORKS OF ROBERT BIRD

\section{RAM.}

Thou liest,-it is here,- my soul is sealed with horror -black, black,- the leprosy of an Ethiop-the gangrene of a demon-all darkness-darkness-of horror.

CAB.

Why, thou madman, wilt thou betray thyself? Think of Juana.

\section{RAM.}

Have I not bought her, even with my soul's perdition? How shall I look her in the face?

CAB.

Hark'ee! I am tired of thy whining. If thou wilt be a man, I am thy friend still; - if thou wilt endanger thyself, and me too, by thy puling, boyish fright, I will leave thee to manage thine own affairs. By my faith, I will.

RAM.

Desert me not, or I have lost Juana.-Give me thy advice; I will follow thy bidding.

CAB.

Let us depart.-Thy father is coming.-They are turning him from the palace.

RAM.

Horror!-I cannot look on him. Away! away!(Exeunt.)> 
SCENE III. A room in Febro's house. (Enter FrANCISCO and LEONOR.)

\section{FRAN.}

Ask me not a word, not now,-not now,-I will tell thee anon.-Our father is alive, I tell thee,alive and well:-Is not that enough? It will break her heart,-Is not that enough? At the palace, I tell thee, sister.

LEON.

I am glad of that.- $\mathrm{He}$ is safe with the Viceroy. And the robbers, Francisco?

FRAN.

Yes, yes!-heaven will discover them.-The robbers! the robbers! Sister, you have done wrong to entertain a lover in secret. My father accuses him of the robbery.

\section{LEON.}

Him! brother! Rolando! what, Rolando! Oh, he was with me. He is a gentleman. - My father does him a great wrong.-

FRAN.

It may be so. Heaven protect thee.-Receive him no more. Tarry here; I will to the vault a moment, -I will be near thee.

\section{(Exit Francisco.)}

\section{(Enter Fernando.)}

LEON.

Oh, Rolando, Rolando, my brother, my father- 
FERN.

Peace, Leonor, I overheard thy brother.-Dost thou think me a robber?

LEON.

What, thou? You must forgive my poor father.This robbery has perplexed him sorely. But what disturbs thee? Thou art very pale, Rolando!

FERN.

Listen: this moment is the last I can look upon theeLEON.

Rolando!

FERN.

If thou wilt fly with me, I will give up my fathermy hopes-my station-everything, for thee; if thou wilt not, I can never look upon thee more.

\section{LEON.}

You are jesting with me, Rolando! Oh, I can never leave my father.

FERN.

Heaven bless thee, Farewell.

LEON.

Rolando!

FERN.

We must forget one another-I could tell thee a reason -but thou wilt hear it from others. 


\section{LEON.}

0, my father! my father!

FERN.

I will love thee better, and forever-Thou shalt be happier too. Thou fliest from misery.

(Exeunt.)

(Re-enter Francisco, with a Rosary.)

FRAN.

This is enough to sear mine eyes forever, And turn my heart to ashes.-Wretched brother! Thrice wretched father! Leonor, ho! Leonor! Sister! Sister! Gone! oh, vanished!-Heaven, Thou art awroth with us! What, sister! sister!

(Exit.) $>$

SCENE IV. The street before MENDOzA's house. (Enter JUANA and RAMON.)

JUAN.

Prosperity,-wealth,-happiness!-They come too late.

Oh, Ramon, Ramon! talk'st thou thus to me?

Witness against thy father! say no more Of happy fortune; but disprove this tale, That racks my heart with horror.-Happy indeed! Thou art awroth with us! What, disprove it: Witness against thy father! Didst thou, Ramon! Say no, and make me happy.

RAM.

They deceived theeI spake no word against him, - not a word, No man can charge me that. 
698 DRAMATIC WORKS OF ROBERT BIRD

JUAN.

No, not a word!-

They charge not that. But thou wert there against him!

Thy presence was enough!

RAM.

Reproach no more:

I chose not to be with his enemies-

They dragged me with them. Speak of this no more.

$$
\text { JUAN. }
$$

Of this forever, till thou clear up all!

Ramon, thou know'st me not.-Be thou the man My hear $t$ has pictured thee, oppressed but worthy, Sore tempted, but with yet a noble spirit, That thrones its nakedness on a rock of honor; And poor and wretched though thou be, deserted, Contemned and hated-nay, by all men cursedStill do I rest thy friend and advocateThy more than friend, thy loving wife forever!

RAM.

I am what thou behold'st-thy long betrothed, Once faith-preserved, and ever faithful RamonOne and the same.

JUAN.

Ah, no, no more the same-

Thy father, Ramon!-

RAM.

Who, for thy love, have borne Sorrow and wrath, and dreamed they were not ills, 
Locked hands with shame, and deemed me undefiled, Councilled with villainy, and thought it virtue, Because it pointed out a path to thee.

$$
\text { JUAN. }
$$

A word

And I have done with thee.-Then for what fate Heaven has in store, the altar or the graveI shall not care.-This do they charge thee, RamonThy father was accused by noted knavesHis son-no, no-his son did not accuse him; But when adjured-(thou tremblest!) When adjured By the poor father, yea, besought, to speak Against the charge which he did know was false, Condemned his father with accusing looksWith a dumb lip assented, and with that silence Sealed him to shame and death!

RAM.

I did all this for thee.

What could I more?

JUAN.

For me! for me!

Thou might'st have stabbed thy brother in the dark, Bartered thy sister for a villain's gold, Done anything unnatural and base, And told me, 'twas for me! for me! for me!

RAM.

Thou art unjust.-In this is grief enough, Without thy keen reproaches.-What could I more? I held my peace.-Wouldst thou have had me charge him? 
JUAN.

Didst thou then know him guilty? Speak me that.

Upon thy soul's eternal welfare speak,

Speak me the truth.-What, dost thou know him guilty?

Know him a felon?

RAM.

This is then thy fear:-

Thou scorn'st the felon's son?

JUAN.

$\mathrm{Hah}$ ! if I do?

What, trap him to't?-Wo's me!

RAM.

Juana, time will show

Who is the guilty wretch-

JUAN.

Oh, Time will show!

Give it not up to time! By all the grief That stains thy sire's gray hairs-by all the pure And solemn magic round thy mother's grave, I charge thee speak the truth.-Thou dost not think Thy father's guilty?

RAM.

Nay, Juana!

JUAN.

Speak,

Or never speak me more.-Tremble not-speakThou dost not think him guilty?- 
RAM.

$$
\text { No,-no,- }
$$

JUAN.

Wretch!-

Thy lips were dumb, and thou didst know him innocent!

You heard him slandered, and stood silent by!

You saw him perish, and held back the truth

That would have saved him!

RAM.

Is it come to this?

Is this the guerdon to reward my love?

JUAN.

Love! Did I love thee! What, this spirit, that, in A case of flesh, was all of adamant-

A disguised devil! Is it come to this?

Thou say'st that well.-For now I know thee well, And hate thee-yes, abhor thee!

RAM.

Thou kill'st me for my faith.

Still unjust,

JUAN.

Now do I know

They spoke the truth, who called thee base and vileThis fiendish act is warranty enough

For any depth of lowness.-Oh, how fallen

Thou art now, Ramon! A year, a month ago!- 
But that no more.-I could have died for thee, Hadst thou held fast to thine integrity-

Now though it break my heart, I cast thee from me

Forever, forever-I'll never see thee more.

\section{RAM.}

Thou mak'st me mad.-The wrongs that I have done I did for thee.-I had no other hope,

No other way to win thee. Dost thou leave me?Then I am lost,- and nothing left with me But the sharp goadings of a vain repentance. False hearted maid! 'tis thou hast led me on Into this gulf of crime: What but a hope To win thee, could have made me what I am A thief and parricide!

JUAN .

Oh, heaven, that opest

Mine eyes upon this horror, still support meA thief! a thief!

RAM.

I said not that.

JUAN .

A demon

Blacker than all! Confess thy crime and die. Confess, for all shall know thee!-O, away, And perish in the desert,-I denounce theeWhat ho, my father-ho!

RAM.

Juana! 
JUAN.

\section{Father!}

Justice! there shall be justice done to all,-

Justice, I tell thee, monster, though I dieJustice, ho, father!

(Enter Mendoza-Ramon fies.)

MEN.

What's the matter, girl?

That wretched Ramon!-

$$
\text { JUAN. }
$$

To the palace, father-

Quick, lead me to the Viceroy.

$$
\text { MEN. }
$$

\section{Art thou raving?}

JUAN.

Oh, father, I've a story for his highness, Will make all rave.-And let me speak it now, While I have strength.

\section{MEN.}

Come in, compose thyself$<$ Thou art disturbed, and know'st not what thou say'st,

The palace, indeed-Thou art fitter for thy couchSo wan and ghastly. $\rightarrow$

JUAN.

The palace, father, the palace! (He leads her in.)

END OF ACT IV. 


\section{ACT V}

SCENE I. A room in FEBRo's house. (Enter Silvano and Febro.)

FEB.

A rogue! a felon! convicted and condemned! No wretch upon the street more given to scornNo mine-slave fretting under blows and lashes, Held to more shame.-Robbed, and for reparation Despoiled of all-even of my children's breadAnd a good honest name too.-Well, indeed, Heaven looks upon the sparrow's unfledged brood, When murderers kill the dam-And Ramon too! Well, I've two children yet;-<where is Francisco? And Leonor? my children? $>$ It is true, Their sire brings shame upon them-But I think They will not turn upon me-Dost thou hear me? Where is Francisco?

SIL.

Oh, alas, dear master,

The house is empty.

FEB. 
SIL.

The doors all open-

No living creatures present but ourselves.

FEB.

$<$ My children, I tell thee!

SIL.

Master!>

FEB.

$\mathrm{O}$, blest heaven,

Strike me to death, for I am desperate-

My children leave me:-Turn my heart to earth, Ere I do curse them!

SIL.

I think, I hope

My mistress now is with Mendoza's daughter.

FEB.

Why, so she is! I should have thought of thatI dare be sworn she is-Francisco too-

Where should he be, but with his sister?-Go-

Fetch them to me. And tell them not to fear

I'll weigh upon them long - this wrong will end

Ere many days, and then men will forget

To charge them with the shame of their dead father.

SIL.

Francisco, sir!

(Enter FRANCISCo.) 
FEB.

My daughter, boy,-my Leonor Where did you leave your sister?

FRAN.

$<0$, dear father,

You'll curse me when I tell you!

FEB.

Ha! ha! eloped!-dishonoured!

Fled, boy, fled!-

FRAN.

Father, dear father

FEB.

Drugged to the bottom!-No gall and venom now, But I must drink them! With a villain fled!

From shame to deeper shame-And in mine hour Of misery too! Oh, curse her! curse her!

FRAN.

Father-

Be not so rash-she may be yet recovered-

FEB.

I gave her to thy charge!>

FRAN.

Oh, dear my father,

I left her but an instant-but an instant

Looked through the vault-and in that instant she Was stolen away-Father, I followed her-

Saw her, at distance, with the ravisher$\mathrm{He}$ bore her to the palace. 
FEB.

To the palace!

A ruffian of the guard-a Spanish ruffian Shall steal my child, and have the Court's protectionI'll have her back though the proud viceroy's self Should bar against me with his villains all-

FRAN.

Father, I followed to the door-the guards Denied me entrance, though I prayed it of themStruck me back with their staves, and with rude voices Taunted and menaced me.

FEB.

Why back again!

Thou wert the felon's son-that was the reason They jeered thee with thine infamy-Thou seest! 'Tis infamy to bear the name of Febro.

Struck thee back with their staves! because thou sought'st

To save thy sister! They shall strike me tooThe blows that bruise the body are not much, When that the heart is crushed-Come thou with meA felon though I be, I will have entranceThough infamous and lost, I will have justice.

(Exeunt.)

SCENE II. A room in the Palace. (PALMera and others discovered.)

PALM.

Frighted with death, and will not make confession?

I know not why-all circumstances bring 
New confirmation of the broker's guilt, And yet, within my breast, some gentle spirit Whispers me doubt, and plays the advocate. That Pablo leave not yet-Hark to me, officer; Carry him to the rack, but harm him not$<$ Place him before the engine, let his fancy Work on its terrors, till it paints his joints Crackling and sundering, his sinews bursting, His strong bones crashing in the ordealNay, for an instant bind him to the wheel, $>$ Make him believe that ye will torture him,(Yet torture not, ye shall not harm a hair-) Thus far put on the executioner, $<$ And, in his terror, if no words of guilt Burst from his lips, my conscience doubts no more, And the poor mad old man is lost forever. $>$

(Exit Officer.)

FEBRO. (Within.)

I will have entrance! Villains, stand aside!

I'll see the Viceroy, and I'll have my daughter!

PALM.

What now! the broker! At this midnight hour, Madding before the palace!

\section{(Re-enter OFFICER.)}

OFF.

Please, your excellency, Febro is struggling with the guards for entrance, He will not be driven back, - he calls your highness, And raves about his daughter. 
PALM.

He is distracted:-

Let him come in-Poor wretch, I pity him.

(Enter Febro, Francisco, and Silvano.)

$<$ What now, old man? What is the matter with thee? $>$

FEB.

You bar your doors against me, and you put Armed rogues therein to thrust me back with staves, And keep my daughter from me.

PALM.

What would you, Febro?

My doors are shut against the ignominious.

FEB.

Ay, ignominious! But I'll have my child<I'll have my daughter; fetch her to me straight, > Were you a crownèd king, I'll have her!

PALM.

Now

What fiend hath seized thee, Febro? If thy child Have fled from thee, heaven pity thy gray hairs, Why shouldst thou seek her here?

FEB.

Why, she is here!

Your rogue has stolen her; you know that wellAnd you protect him. <Oh, heaven visit you With pangs and misery. $>$ Give me back my childGive me my daughter, and I will forgive you The other mischiefs you have done me. 
PALM.

Alas,

'Tis madness fills thee with this fantasy:

$<$ How should thy child be here!

FEB.

Will you not yield her?>

I do beseech you, give me back my child-

My loving Leonor! Oh, now, for pity,

(He kneels.)

Be just to me. Look on me, noble sir,

You have broke my heart, but give me back my daughter.

PALM.

Rise up, thou old and miserable man,

I pity thee, but know not of thy child.

FEB. (Arising.)

I do demand her; keep her, if you dare!

What if $I$ be a miserable man,

A gray, old, broken, miserable man,

A most dishonest and convicted felon,

Ashes upon my head, and, in my heart,

Anguish that's measureless-a man despised,

Stained, shunned, shut out from all men's sympathies?

I have my rights, and, though so friendless, seek them;

I have my rights, and, though so poor, will speak them;

$<I$ have my rights, and, though so weak, will have them. $>$

I ask my child, and, by my life, I'll have her.

I say I'll have her.-Some ruffian of your guard

Ravished her from me, while you kept me here-

Rolando- 
PALM.

Again art thou deceived, I have no villains in my keeping, Febro, And know, - of all my household, there is none So named Rolando.

FEB.

'Tis a false name, then, The wretch is here-he has my daughter tooFrancisco followed him, and saw him enter, My daughter with him.

PALM.

Say'st thou this, Francisco?

FRAN.

I do, my lord; I followed him, and saw him Pass, with my sister, through the private gate-

PALM.

What ho, my guard!- the axeman with his block! Let every man o' the court appear before me. Thou shalt have justice, Febro, on the head Of him that wrongs thee.

\section{(All come in.)}

If thou know'st the man Point me him out among this multitude, Dishonored though thou be, by all the saints, There is no man so noble, that shall wrong thee. And pay no reckoning to thy miseries. 
FEB.

Hah! no, no, thou art not Rolando-No-

Dost thou not see him, boy? <Is he not here?

Mine eyes are dimming. $>$ Let the villain speak,

If he will straightway give me up my child,

I will forgive him;-yea-and will pursue

This thing no further.

FRAN.

Rolando is not here.

PALM.

Thou seest, thou wert mistaken boy.

FRAN.

Your highness, no-

I saw them well, Rolando and my sister-

She turned her face, when I did call to her;

Rolando dragged her on.-

PALM.

Are all men here?

This moves me much. Search thou the palace o'er. (To an OFFICER.)

Every man's lodge, even to mine own apartments.

Let no man stay thee. (Exit OfFICER.) Hath any of the guard

Fled from the palace? The ruffian shall be found; I'll search the city for him.

(Enter Fernando.)

FEB.

Hah! 
FRAN.

Rolando!

FEB.

Ha! ha! the rogue! the villain! I have him fast!

Give up my child!

PAI.M.

How! Febro!

FEB.

This is the man!

PALM.

$<$ My son! my son! Down from my seat of pomp, Into the earth of shame; I am as miserable, As wretched now as Febro. Dost thou charge him? What him, Baptista?> This is my son, Fernando!

FEB.

Thy son? Thy son shall ruin my poor girl, And break my heart! Oh, wretch, where is my daughter?

$<$ Thou didst delude her from me! Ruined, ruined! Howl thou in hell for this! yes, howl, forever!> Thou hast stolen the dearest daughter of the earth, And given her up to shame; oh, heaven distract thee, Make thy heart mad, but not thy brain, that thou May'st rot within, and have a sense of it!

<FERN.

Oh, saints, avert this curse, so undeserved. Most rash old man.> 
7I4 DRAMATIC WORKS OF ROBERT BIRD

PALM.

Didst thou ensnare the girl?

$<$ Oh, wretched boy! >

FERN.

Dear father! Father, pardon! (Kneeling.)

FEB.

You hear him? He confesses. <0 bitter wretch!>

PALM.

Stand up before me as a criminal, What-to his chambers! Bring the maiden forth, Old man, thou shalt have justice, though the gift Leave me all childless.

(Some Officers go out.)

FERN.

Father!

PALM.

Peace, false wretch-

Thy judge-no more thy father. ( $A$ noise.) More woes to mad us!

What cry is this?

(Cries of "Febro is innocent!")

(RAMON and CABA RERO are brought in, and JUANA and Mendoza.)

JUAN.

Justice, your excellency!

Justice for Febro! Villains have entrapped him! False witnesses have sworn his life away, And there thou seest the falsest! 
FEB.

$<\mathrm{Oh}$, the villain!

Give me my daughter, and then judge the rogues. $>$

PALM.

Speak, maiden, speak-if heaven have left me now One satisfaction greater than the grave, 'T will be to right this wronged man. Which is he Thou call'st the falsest witness?

JUAN.

Look-'tis Ramon-

FEB.

Ramon, my son!

JUAN.

He did confess to me,

He knew his father innocent.

FEB.

Oho, you hear!

I knew my boy would right me.

(Going toward RAMON.)

JUAN.

Hence, stand back,

Touch not corruption-look on him no more.

I do denounce him to your excellency, As one conspiring 'gainst his father's life.

PALM.

Oh, most unnatural- 
716 DRAMATIC WORKS OF ROBERT BIRD

FEB.

Hearken not to herMy Ramon ne'er conspired against me.

$$
\text { JUAN. }
$$

Hear me.

He was my betrothed spouse, and well I loved him:I give him up to justice, and accuse him, Even on his own admission, that he isI live to say't - a false witness and a robber!

$$
\text { < PALM. }
$$

Can this be so?>

FEB.

$\mathrm{Oh}$, thou unnatural girl!

Hearken no more, your highness-she belies him.(Re-enter IST OFFICER.)

Ramon is wronged, and very innocent.

\section{IST OFF.}

Please, your excellency,

Pablo, in terror of the rack, confesses,-

FEB.

Pablo's the rogue and robber.

\section{IST OfF.}

He confesses

Himself participant in the robbery-

CAB.

He lies, base knave! 


\section{IST OFF.}

And charges, with his oath,

This man, Antonio, and the broker's son

Ramon, to be his principals.

PALM.

And I have wronged thee, Febro?

Just heaven!

FEB.

Pablo's a rogue!

$<$ What, Ramon? Ramon rob me? Ramon, my son!>

I warn your highness, Pablo is a rogue, Not to be trusted.

CAB.

An atrocious rogue-

A rogue foresworn-and moved to this invention By terror of the wheel.

FRAN.

Brother, confess-

RAM.

Away-

FRAN.

Confess, and save thy father's life-

Repair the wrongs which thou hast done him.

FEB.

What dost thou mean?

Sirrah, 
FRAN.

What, not a word? Oh, heaven, Look down with pity on my father now! Oh, now, your highness, spare my brother's life, For he is guilty of the robbery.

$<$ CAB.

$<$ Hark to the cub!- -next he accuses me. $>$

FEB.

Why, thou base boy, dost thou accuse thy brother? Thy brother, wretch?

FRAN.

Father, I do; forgive me.

FEB.

I curse thee, devil!

FRAN.

Oh, curse me not, my fatherI charge him to save thee-Hear me, my fatherThou know'st this rosary-

FEB.

'Tis Ramon's-ay-

It was his mother's, and to keep her ever Before his eyes - his pure and holy motherWith mine own hands I hung it round his neck, To be the talisman of his memory.

FRAN.

Father, this found I in the vault. 
FEB.

The vault!

Ramon! my son! My Ramon!-

RAM.

Guilty! guilty!

Give me to death-for I have killed my father!

I am the robber and the parricide-

The doomed and lost-the lost-oh, lost forever!

(Rushes out.)

PALM.

Secure young Ramon:-This vile Antonio tooThis devil-born destroyer of men's sons:

I'll make him an example. Look to them-

Have them in waiting.

(CABARERO is taken out. MENDOZA goes with them.)

Fy, how now, Baptista?

We have done thee wrong?

FEB.

Confess and pray-Call Leonor!

Well, boy, we will go home-

FRAN.

Oh, father!

PALM.

His wits are fled-oh, fate, these thunderpeals So flashing through the heart, have done their work, And the mind's temple tumbles into ruin.

Arouse thee, Febro! Thy wealth shall be restoredLucas, the miner, hath his pit recovered, And pays thee back a golden recompense. 
FRAN.

He thinks no more of that.

PALM.

Thy daughter, Ferbo!

FEB.

I'll have you moan for this!

PALM.

Thou shalt have justice.

(LEONOR is brought in.)

Behold thy daughter! Thou shalt have justice full.

FEB.

My child! my child!

LEON.

Dear father! (Kneels.)

FEB.

O man of stone!

Was I not wo enough, but you must steal

My seraph from me?

PALM.

Name thou his punishment.

If it be death, the knave shall die.

FERN. (Kneeling.)

Forgive me!

I could not speak while Febro seemed a felon;

Punish me now, since he is innocent. 
I stole thy daughter, but I wronged her not; Sire, I deceived thee, but I am no villainRevoke thy curse: and, father, bless my wife!

FEB.

Is it even so? thy wife?

PALM.

Naught else is left

For reparation-I the rites acknowledge And as my daughter here do welcome her.

FEB.

Thy wife! thy honored wife!-You do receive her? Why, now we shall be happy-Heaven be thanked! $\mathrm{Ha}$, ha! a noble husband for my daughter! $<$ A virtuous, honorable gentleman! $>$ I'll make thee rich! She's worthy of a king.Happy! happy!

(A cry.)

(Re-enter MENDOZA, with an Officer.) MEN.

Alas, your highness, Ramon-

FEB.

Hah, Ramon!-Oh, thy white and quivering lips Speak a new horror!

\section{MEN.}

Pitying his grief,

And agony of mind, we led him forth On the balcony, where, confessing straight In what dark corner he had hid the gold, $O$ ' the sudden, with a shriek of desperation, He flung him from the height-and- 
722 DRAMATIC WORKS OF ROBERT BIRD

PALM.

Heaven!

MEN.

So perished.

[FEB.

God, God, God!] (Febro falls.)

< PALM.

What, Febro? Hast this last blow cracked thy heart?

There comes no sin without its sequent wo;-

No folly but begets its punishment;

And heaven, that strikes the malefactor down, Even with the greater culprits smites the lessThe rigid sire and disobedient son. $>$

THE END. 


\section{INDEX}

Adventures of Robin Day, The, 8, 9, I4, I5, 105

American Monthly Magazine, The, I04, I I2, I1 3, II 4

Appearance, Bird's personal, $82,122,154$

Armitage, Ann, 5

- Hon. James, 5

Baltimore Convention, I27, I28, I29, I3I

Barr, Rev. Samuel, 5, 6, I6

Bird, Rev. Frederick M., I05,

I 14, I28, I29, 146

- John, I, 2

John, III., 3, 5, 6

Mrs. Mary, 8, 9, 29, 71 ,

I22, I30, I 5I, I 55

Robert Montgomery,

birth, I; parentage, I-5; childhood, 6-12; school days at New Castle Academy, I315, 20, 21 ; in Philadelphia, 19, 20; at Germantown Academy, 21-23; at University of Pennsylvania, 23-27; medical practice, 28 ; literary apprenticeship, 32-35; Pelopidas, 37, 38; The Gladiator, 38-49; meets Forrest, 39; Oralloossa, 53-55; travels with Forrest, 55-57; The Broker of Bogota, 57-60; rewrites Metamora, 60, 6I ; The Gladiator in England, 6I-65; personal and financial relations with Forrest, 68$7 \mathrm{I}$; Bird's sources, aims, and methods of workmanship,
71-75; Calavar, 77-82; in England, 82-86; The Infidel, 86-90; Hawks of Hawk Hollow, 90-91; Sheppard Lee, 93-96; Nick of the Woods, 96-98; Magazines, 98-104; Peter Pilgrim, 104, I05; Adventures of Robin Day, 105; income from novels, 106; English editions, I06107; marriage, I08-I10; farming, I I5-II9; teaching, I23-I25; politics, I25-I29; journalism, I33-I 43, I 44, I5O, I5I; death, I5I-I53; rank as man of letters, I53I 59

- Thomas, 2,3 Thomas Jefferson, 32 $\&$ Riddle, 6

Black, Dr., 23, 24, 26, 27

Boker, George H., 39, I 47-I50

Brewer, John M., 21, 22

Broker of Bogota, The, 57-60, I 26, I46, I 56, I 57, 577-722

Brown, Brockden, 156

Bryant, William Cullen, 37

Bulwer, Sir Edward Lytton, $84,85,86$

Burton, William E., I19, I20, I2I

Cabin Cave, II 5-II9, I21, 122 Calavar, 77-82, 83, 84, 85, 86, I55, 166

Caridorf, 26, 35

City Looking Glass, The, 33, 35

Clark, L. Gaylord, 99, I 3 I

Clark, W. Gaylord, 99 
Clarke, Thomas Cottrel, 99, I I I

Clay, Henry, 127, 135, 136

Clayton, John M., 125, 127 , 128, I3 I, I33, I37, I43, 145 , 146,152

Conrad, Judge R. T., I I9, I20, I34, I35, I36

Cooper, James F., 29, 77, 97, 98,158

Copyright, International, IoI104

Cowled Lover, The, 26, 35

Death, $151-153$

Death of Meleager, The, 26

Downing, Robert, 154

Dramatic Author's Bill, 147I50

Dramatization of novels, 107

Dunlap, William, 31, 32

Durang, Charles, 44

Elizabethan Drama, Bird on, 25,26

Emerson, R. W., 30

Empson, Cornelius, 2

English Editions of Bird, I06, I07, 155

Episcopalian Church, The, 19

Fanatick, The, 34

Farming, I15-I 19, I21, 122

Forrest, Edwin, 36-40, 4I-49, $53-55,6 \mathrm{I}-65,65-68,68-7 \mathrm{I}$, I 19, I20, I3 I, I45, 146, 154, I 56,158

French and Indian War, 4

Friendships, 130, I3I

Frost, John, I20, I21, I3I, 132

Germantown Academy, The, $21,22,23,123$

Gladiator, The, 38-4I, 4I-44, 44-49, 5I, 52, 6I-65, 65-68, $72,120,126,146,156,157$, 297-440

Giannone, 34

Godey's Lady's Book, 99
Graham, George R., I19, I33, $134,135,136,137,138,140$

Grimes, John, 26, 92, 93, 105

Halleck, Fitz-Greene, 37

Hawks of Hawk Hollow, The, 90-9I, 106

Hoffman, Charles Fenno, 99, I I I, I I 2

Home-life, Bird's, 130

Howe, Samuel G., II2

Ice Island, The, 35

IIl health, II, II $4,144,150$, 151

Income from novels, 106

Infidel, The, 86-90, 156

Ipsico Poe, 105

Isidora, 34

Johnson, Walter R., 21-23, 123

Jones, Joseph S., 3I

Journalism, 133-I 44

Knickerbocker Magazine, 86, 99, 100, 10I-104, I10

King Philip, 34

Lafayette, General, 7, 9, 1 I

Lawson, James, 37, 82, 86-88, 89, I3I

Leggett, William, 36, 37

Lexington, Battle of, 4

Lounsbury, Thomas R., 30

Magazines, Bird and the, 98I04, I IO-I I3

Mammoth Cave, 92, I05, I 12

Marriage, Bird's, 108

Martineau, Harriet, I02-I04

Matthews, Brander, 29

Mayer, family, The, 109-1 Io

- Dr. Edward R., 6I, I5I, I52, I 53

- Misses, 83, 84, 109, 110

- Rev. Philip F., I09, I I0, 132

McClellan, Dr. George, II9, 120, I21, 123, 125, 131, 132, 146

McCullough, John, I54, $15^{8}$ 
McKean, Thomas, 4

McMichael, Morton, 133, 134, 135, I36, 138, I40

Medical practice, 28

Men of the Hills, 34

Metamora, 37, 60-6I, 70

Mexico, Bird's interest in, 55, 57,77

New Amstel, II, I6

New Castle, I, 3, 4, 5, 6, 9, 10I6, 20, 21, I I 5, I 22, I25, I27, 138

New Castle Academy, 3, 13I5, 20, 21

News of the Night, 26

Nick of the Woods, 27, 96-98, I 47, I 54, I55

North American, The, 132, 133I 43, I 5 I, I 59

Oralloossa, 53-55, 126, 146, 156, $157,44 \mathrm{I}-576$

Parrish, Dr. Joseph, 24

Pelopidas, 37-38, I19, I20, I2I, I 26, I 57, I 7 I-296

Pennypacker, Hon. S. W., 155 Pennsylvania Medical College, 123

Philadelphia, 16, 20, 24, 27, 28, $32,40,43,52,53,54,57,94$, I 08, I09, I I I, I I 2, I I 9, I 23, I33, I34, I36, I 53

Philadelphia Central High School, I32

Philadelphia Monthly Magazine, The, 26, 33

Poe, Edgar A., 91, 95, 100-IoI

Political Life, Bird's, I25-129

Powers, Hiram, I3I
Prescott, W. H., ${ }^{8} 8$

Presbyterian Church, The, 7

Rodney, Miss Emily, 22

Saul's Last Day, 26

Scott, Sir Walter, 29, 87, 88, 9I, IOI, I 58, I59

Secret Records, 39-4I, 50-52, 74-75

Sheppard Lee, 93-96

Smithsonian Institution, 126, 127, 132, 133

Snowden's Magazine, 23, 76

Southern Literary Messenger, IOO-IOI, I IO

Spirit of the Reeds, The, 35

Stone, John Augustus, 37, 60$6 I, 70$

Teaching, 123-I25

'Twas All for the Best, 26, 35

University of Pennsylvania, 23-27, 29, I IO

Van Dyke, Dorcas, 8, 9, I08, I09

Hon. Nicholas, 5, 6, 7, 10, I 5, I7-19

Van Leuvenigh, Elizabeth, 3, $5,6,16-19$

- Hendrick, 4 Zachariah, 4, 5

Volunteers, The, 34

Wetmore, Prosper M., 37, 57

Whig Party, The, 125, 126, 127 , 128, 129

Willis, Nathaniel Parker, 90, 9I 


$$
L E
$$






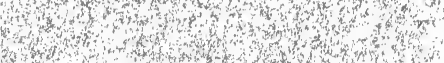

ais

$$
\text { (1) }
$$
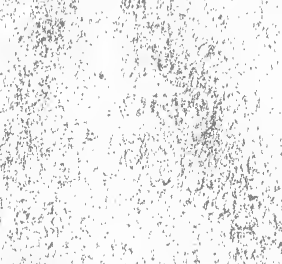


\section{DAY USE}

RETURN TO DESK FROM WHICH BORROWED

\section{LOAN DEPT.}

This book is due on the last date stamped below, or on the date to which renewed.

Renewed books are subject to immediate recall.

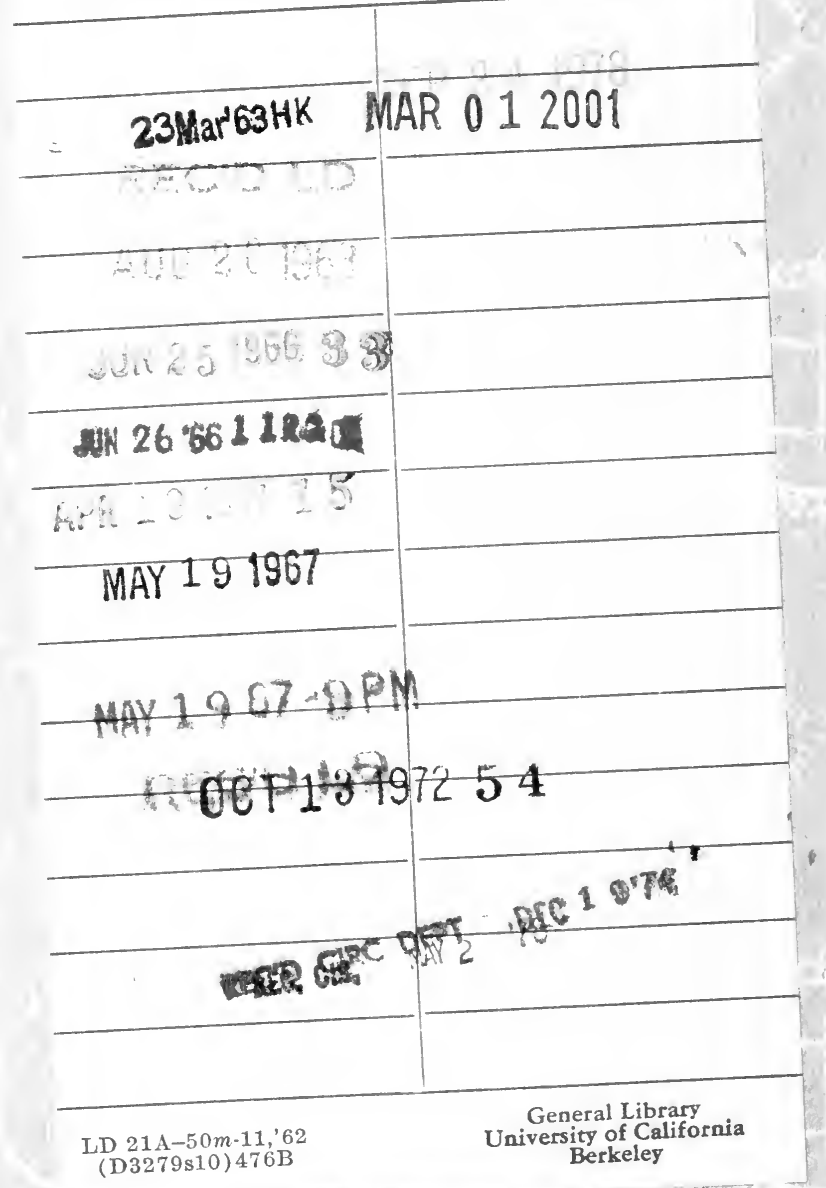




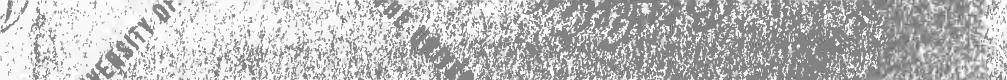
(1) W (x) 1.

w.

(t)

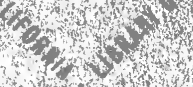

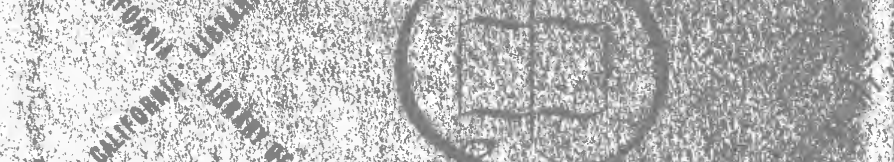

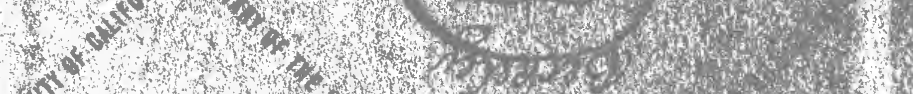
(1)

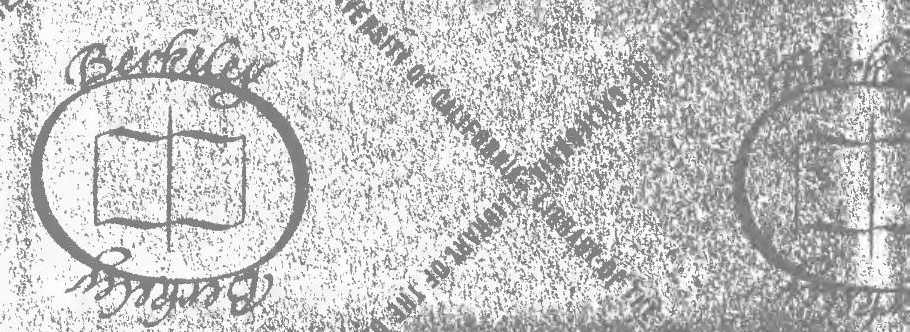


